\title{
IN THE EYE OF THE BEHOLDER
}

What Six Nineteenth-century Women Tell Us About Indigenous Authority and Identity 


\begin{abstract}
Aboriginal History Incorporated
Aboriginal History Inc. is a part of the Australian Centre for Indigenous History, Research School of Social Sciences, The Australian National University, and gratefully acknowledges the support of the School of History and the National Centre for Indigenous Studies, The Australian National University. Aboriginal History Inc. is administered by an Editorial Board which is responsible for all unsigned material. Views and opinions expressed by the author are not necessarily shared by Board members.
\end{abstract}

\title{
Contacting Aboriginal History
}

All correspondence should be addressed to the Editors, Aboriginal History Inc., ACIH, School of History, RSSS, 9 Fellows Road (Coombs Building), Acton, ANU, 2601, or aboriginal.history@anu.edu.au.

WARNING: Readers are notified that this publication may contain names or images of deceased persons. 


\title{
IN THE EYE OF THE BEHOLDER
}

What Six Nineteenth-century Women Tell Us About Indigenous Authority and Identity

\author{
Barbara Dawson
}

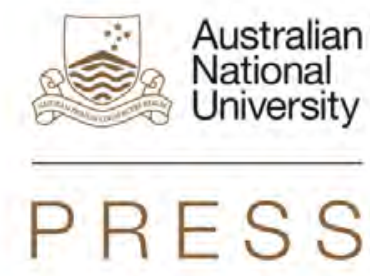




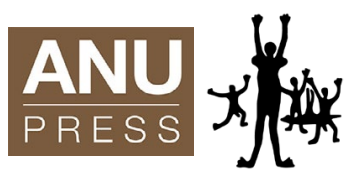

Published by ANU Press

The Australian National University

Canberra ACT 0200, Australia

Email: anupress@anu.edu.au

This title is also available online at http://press.anu.edu.au

National Library of Australia Cataloguing-in-Publication entry

Author: Dawson, Barbara (Barbara Chambers), author.

Title: In the eye of the beholder : what six nineteenth-century women tell us about indigenous authority and identity / Barbara Dawson.

ISBN: 9781925021967 (paperback) 9781925021974 (ebook)

Subjects: $\quad$ Women pioneers--Australia--Attitudes. Intercultural communication--Australia--19th century. Aboriginal Australians--Public opinion--History. Aboriginal Australians, Treatment of--Australia--History--1788-1900. Australia--Race relations--History--1788-1900.

Dewey Number:

305.40994

All rights reserved. No part of this publication may be reproduced, stored in a retrieval system or transmitted in any form or by any means, electronic, mechanical, photocopying or otherwise, without the prior permission of the publisher.

Cover image: From Typical portraits of the aboriginals 1847 by George French Angas; JW Giles. National Library of Australia, NK 54/35, accn U1371.

Cover design and layout by ANU Press

Printed by Griffin Press

This edition (C) 2014 ANU Press 


\section{Contents}

Notice to Indigenous Readers . . . . . . . . . . . . . . vii Maps . . . . . . . . . . . . . . . . . . . ix

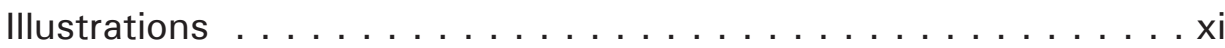

Acknowledgments. . . . . . . . . . . . . . xiii

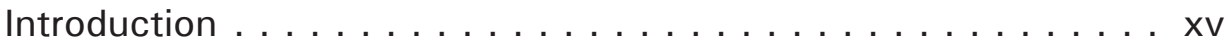

1. Sowing the Seeds for Nineteenth-century and Early

Twentieth-century Women's Writing . . . . . . . . . . . . 1

\section{Part A Adventurers}

2. Early Perceptions of Aborigines-Eliza Fraser's Legacy:

'Through a Glass Darkly' . . . . . . . . . . . . . . . . . . 11

3. Literary Excesses-Eliza Davies: Imagination and Fabrication 29

4. Queensland Frontier Adventure-Emily Cowl:

Excitement and Humour. . . . . . . . . . . . . . . . . . . 51

\section{Part B Settlers: Changing the Racial Landscape}

5. An Early, Short-term Settler-Katherine Kirkland:

Valuable Insights Through the Silences . . . . . . . . . 73

6. Mary McConnel: Christianising the Aborigines? . . . . . . . . 99

7. Australian-born Settler-Rose Scott Cowen:

Acknowledging Indigenous Humanity and Integrity . . . . . 125

Conclusion . . . . . . . . . . . . . . . . . . . 151

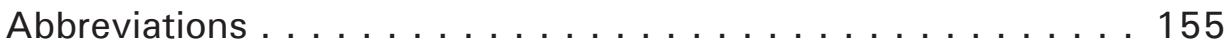

Appendix A: The Works of the Women Writers . . . . . . . . 157

Appendix B: The Works of Other Australian Women Writers

Referred to in this Book . . . . . . . . . . . . . . . . . . 159

Bibliography . . . . . . . . . . . . . . . . . . . 161

Index. . . . . . . . . . . . . . . . . . . . . . . 191 

What might have been is an abstraction

Remaining a perpetual possibility

Only in a world of speculation.

T S Eliot, 'Burnt Norton', Four Quartets.

\section{Notice to Indigenous Readers}

Some nineteenth and early twentieth-century words and phrases quoted in this book are considered offensive by today's standards. In repeating these words I mean no disrespect nor wish to cause any offence to Aboriginal people. 



\section{Maps}

Note: On the regional maps the locations of towns are marked by round dots, and properties with squares and their names in full capitals.

$1 \quad$ Location of regional maps. xvi

2 Eliza Fraser. South-east Queensland coast showing location of Fraser Island and on the right detail of the immediate Fraser Island area.

3 Eliza Davies. South central South Australia in the vicinity of Gulf St Vincent and the lower course of the Murray River showing the route of the Sturt expedition in 1839.

4 Emily Cowl. Northern Queensland showing places mentioned in the text around Normanton near the Gulf of Carpentaria, the Etheridge Goldfield and the Rockhampton district.

5 Katherine Kirkland. South central Victoria west from Melbourne including route taken by Katherine Kirkland to Trawalla.

6 Mary McConnel. South-east Queensland including Moreton Bay, Brisbane and the Brisbane River district.

7 Rose Scott Cowen. Central Queensland localities west of Rockhampton in the vicinity of the Dawson, Barcoo and Thomson rivers. 



\section{Illustrations}

$1 \quad$ Engraving of Eliza Fraser. 11

2 Ka'bi country: the long trek south, Fraser Island. 15

3 Marshy ground on the banks of the Noosa River near Fig Tree 20 Point, where Eliza Fraser lived with the Ka'bi people.

4 Eliza Davies. 29

$5 \quad$ Eliza Davies in boat, Ngarrindjeri family left foreground. 39

$6 \quad$ Thomas and Emily Cowl, 'The Event of their Golden Wedding'. 51

7 Katherine Hamilton, later Kirkland. 73

8 Trawalla Homestead. 84

$9 \quad$ Katherine Kirkland's dairy. $\quad 88$

10 David and Mary McConnel. 99

11 Bulimba homestead, now located in the Brisbane 104 suburb, Bulimba.

12 Cressbrook homestead, Dungibara left foreground. 112

13 Dungibara child wearing red coat. 118

14 McConnel family at Cressbrook station, c. 1887.

15 Rose Scott Cowen. 125

16 Tambo station, $1880 . \quad 128$

17 Farm buildings, Tambo station. 131

18 'My beloved West'. 133 



\section{Acknowledgments}

The genesis of this book was my PhD thesis in the School of History at The Australian National University. Many people helped me along the way and I thank especially my supervisor, Tim Rowse, who applied his expert conceptual eye to the final product. I also thank my associate supervisors, Tom Griffiths and F B (Barry) Smith: Tom for his practical support and advice, and his encouragement and interest that continued into the completion of this book. His six-monthly 'Morning Conversations' brought together his many $\mathrm{PhD}$ candidates for discussion and camaraderie which supported and enriched our academic endeavours; and Barry for his eagle eye for precision and his skill for detail. I am immensely grateful to Tim, Tom and Barry for sharing their intellectual rigour and their deep historical knowledge.

I thank the visitors, students and staff at the Research School of Social Studies, ANU, for their friendship and encouragement and particularly Ann McGrath, director of the National Centre for Indigenous History, Gordon Briscoe, Margaret Steven, Marika Ainley (University of Victoria, Canada), Kirsty Douglas, Rani Kerin, John Thompson and Ingereth Macfarlane (then editor of Aboriginal History). To my former work colleagues at the Australian Dictionary of Biography, National Centre of Biography, RSSS, ANU, thank you for accommodating so happily my part-time study. I am also very grateful to Jenny Sheehan, CartoGIS, ANU, for drawing my maps.

What would researchers do without the friendly and efficient staff of libraries and archives? I thank Andrew Sergeant, Mary Gosling and all the other cheerful and accommodating librarians who work in the scholarly haven of the Petherick Reading Room at the National Library of Australia. I also thank the librarians from the Chifley and Menzies libraries at ANU, AIATSIS and the State Library of New South Wales and the archivists from the Noel Butlin Archives Centre (and especially Pennie Pemberton who shared with me her expert knowledge of the Australian Agricultural Co.), and the State Records Authority of New South Wales, formerly at The Rocks, Sydney. Thanks also to Queensland Art Gallery's Michael Hawker and Judy Gunning for permission and help in using the painting from Northern Journey: Conrad Martens in Early Queensland [online exhibition catalogue], Queensland Art Gallery, Brisbane, 2001. ${ }^{1}$

To my many friends in the Petherick Room thank you for your input and interest. My 'intelligent lay reader', the late Merv Palmer, also steered me safely through

1 http://www.visualarts.qld.gov.au/content/martens_home.asp?name=Martens_Home. 
the subject of ships, shipping and all things nautical, being particularly helpful in the deciphering of sea charts to try to work out the ultimately unfathomable boat trips of Eliza Fraser.

Many people associated with the writers featured in this book, or with their homesteads and homes, have been generous with their time or hospitality. These included Fiona Mackenzie (whose family owned Trawalla from the 1920s) and Georgia Hamilton Scott (Katherine Kirkland's English great-greatgreat-granddaughter), who adopted the role of 'go-between' with her mother, uncle, and grandmother Sheila Kirkland Wilson; Celia Burnham (born Scott) of Boninyong station; P F B Alsop (Geelong Historical Society) and Dorothy Konig (Ararat Historical Society); C D McConnel, his sister Diana Rogers (Mary McConnel's great-great-granddaughter), and Susie Griffiths (Bulimba); Rose Scott Cowen's grand-daughters Shirley McPherson and Judith Hayne, and especially her great-niece, Rosemary Eckel (Tambo); Dave Nugent (Tambo station); Melvyn Dales (Longford station), Ray Wilson (Moyen station), who would have taken me into Longford in his helicopter if the winds had been lighter, and Ivy Rayment (Jundah); and Marie McCulloch, Research and Education Officer, Queensland Family History Society, Albion.

In the publishing of this book, I am grateful to my manuscript reviewers, whose comments helped me improve the work. I thank Rani Kerin, the editor of the Aboriginal History monograph series, and Melanie Nolan for initial discussions. I am also very appreciative to the staff of ANU Press, particularly Dave Gardiner and Nausica Pinar, and I especially thank copy-editor Geoff Hunt for his superb assistance.

To my patient husband, Graham, thank you for sharing (if not taking over the bulk of) the driving to outback locations (and particularly on the highways teeming with kangaroos between Charleville and Longreach at sunset)! I dedicate the book to my children Drew, Gregour, Angie and Dave to remind them that it has happened! 


\section{Introduction}

In the words of J J Healy, 'The destruction of the Aboriginal society went hand in hand with the formation of a European society'. ${ }^{1}$ My aim in this book is to help write the story of Indigenous Australians into the Australian legend by resurrecting pockets of insight of Aboriginal culture before, or soon after, its subjugation and reassessment after British settlement. In doing so, I look at aspects of Indigenous social and culture life at the time of first or early contact, as represented in the reports or published memoirs of six colonial women. The book probes how the perception of Aborigines was first set down and how their character was distorted by ignorance and, sometimes, deception.

From the broader scope of my PhD thesis, 'In the Eye of the Beholder: Representations of Australian Aborigines in the Published Works of Australian Women Writers', I have tweaked the analysis to favour the Indigenous people's own 'eye' on the white supremacists. In doing so, I have altered the emphasis from the white women's 'representations' of Aborigines to highlight the strength and authority of Indigenous Australians on inland locations at first and early contact, and into the first decades of the twentieth century.

The book introduces a set of quite obscure colonial women's writing (apart from Eliza Fraser) and interrogates them for what they reveal about the writers' (and broader society's) attitudes to, views on, and beliefs about Aboriginal people. The texts span the period from the 1830s to the early twentieth century and cross the colonies themselves. The selection and organisation of the six texts have enabled me to map a gradual dismantling of racial stereotypes and changing attitudes. My argument follows the line that this 'progression' was as much a product of the times, as it was of the force of personality of the writers and the Aboriginal women with whom they coexisted.

My interest in studying women on colonial frontiers ${ }^{2}$ began when I was writing a Master of Arts thesis on nineteenth-century land settlement on the New South Wales southern Monaro property, Bibbenluke. ${ }^{3}$ Immersed in the life of squatters, selectors, shepherds and shearers, I itched to answer the questions: Where were the women? What were they doing? What kind of life were they living? I later found from Joy Hooton and Kay Walsh's Australian Autobiographical

1 Healy 1978: 2.

2 Dr Gordon Briscoe has pointed out to me that 'frontier' — an Old French-Middle English word used in the United States of America to refer to that part of the country which formed the border of its settled or 'uninhabited' regions - is a term inapplicable to the notion of country for Indigenous people. It has been used, however, in Australian English since 1840 to describe the edge of occupation, Arthur 2003: 33. As it has become accepted in Australian colonial histories, I have used it in this book. Tom Griffiths offers Australian alternatives, including 'the outback', Griffiths and Robin 1997: 10.

3 Dawson 1996. 
Narratives: An Annotated Bibliography that many colonial women had recorded their experiences in rural outposts. I saw that a number had written about their contact with Aborigines, particularly with Aboriginal women. I subsequently chose six women (all British) whose narratives offered an examination of the relationships between non-Indigenous and Indigenous women (through the eyes of the white women). All wrote in some detail about their impressions, opinions and attitudes concerning Indigenous people.

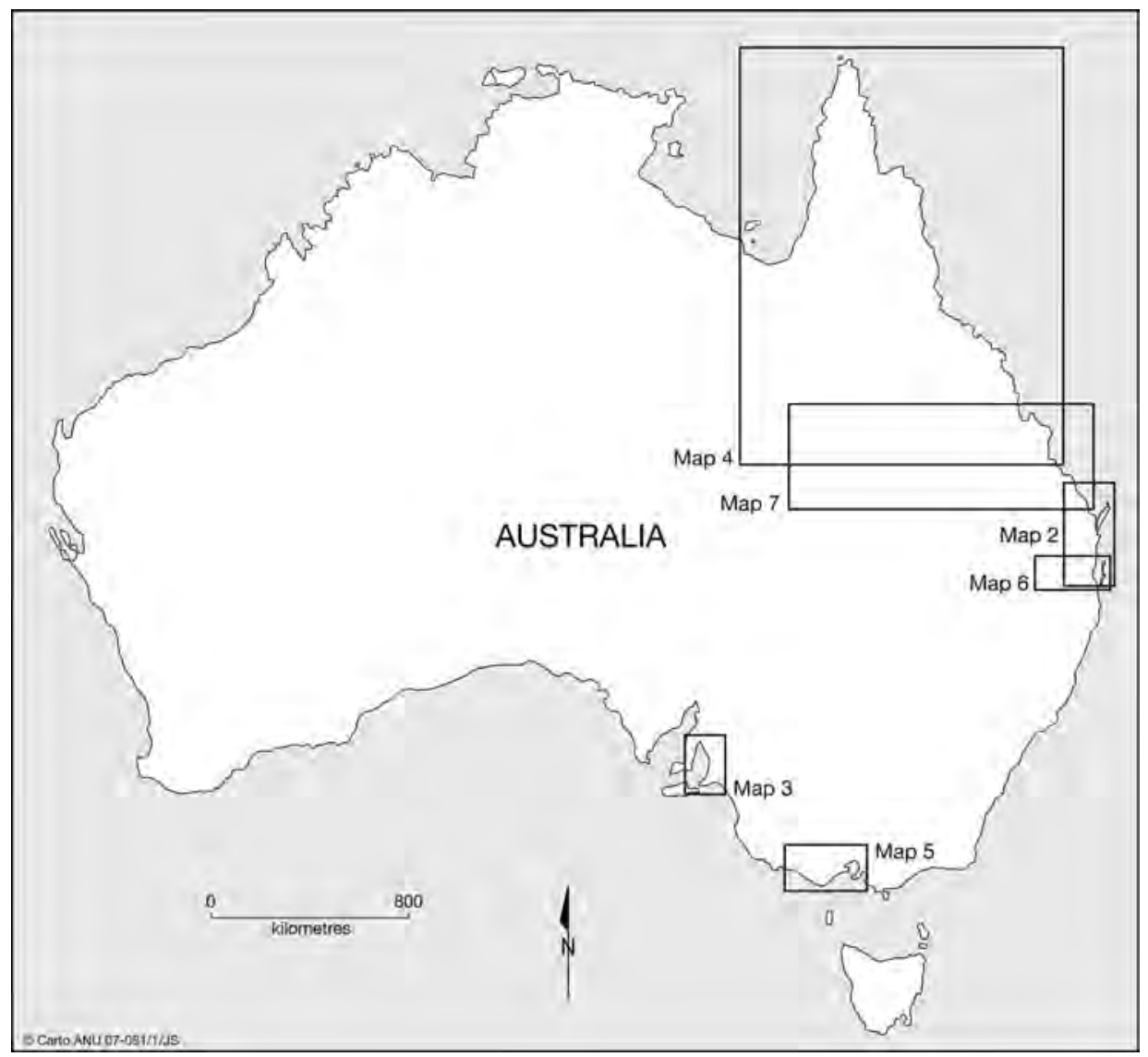

\section{Map 1. Location of regional maps.}

Note: Map 2, Eliza Fraser; Map 3, Eliza Davies; Map 4, Emily Cowl; Map 5, Katherine Kirkland; Map 6 , Mary McConnel; Map 7, Rose Scott Cowen.

Source: CartoGIS, College of Asia and the Pacific, ANU.

With the exception of Eliza Fraser — whose story I chose to examine as the iconic precursor of derogatory renditions of Indigenous Australians - these accounts of first-hand experiences on the frontiers came from previously unexamined 
historical texts. These are little known works that bring to light the negotiations of place and identity in a precise socio-historical context. A strong sense of regional and individual differences emerge and offer the opportunity for a detailed history that is attentive to the concepts of faith, values, experiences and belief. Within this cadre of writers I re-examine generalisations about gender, class, race and the Australian frontiers of settlement. In addition, I have been able to look at the way that thinking about self ${ }^{4}$ and others was reshaped.

My selection of writers was guided by narratives that either exemplified current social and racial attitudes, or moved in perception away from these constraints. I was interested in examining the extent to which the writers adhered to racial clichés or rejected them. My method was to undertake intensive historical research that took in relevant biographical details of the writer and her family, the historical context and 'straight' textual readings. The biographical investigation included the writer's social background and connections, her class position and religious views, changing literary tastes and access to education and literacy. Broader ideas about Indigenous Australians and racial hierarchies, historical contexts, such as frontier violence and its memory, phases of pastoral development and changes in land use, the expansion of settlement, legislative measures and individual characteristics and personalities - of both the writer and the Aboriginal people (especially the women, with whom close relations were formed) — were also factors and influences.

The division of the book into Adventurers and Settlers allowed me to differentiate between short-term 'visitors' or travellers to a frontier location, and women who settled in rural outposts. I was able to pose questions about how the timing and length of residence in Australia, and the time of writing and publishing, influenced the women's interpretation of Indigenous people. The differences between the three 'adventurers' and the three 'settlers' pivoted on the ephemeral nature of the adventurers' experiences with Indigenous people, compared with the settlers' longer-term relationship with them.

I need here to clarify that the Indigenous Australian people who related to settler women were 'civilised' or 'station' Aborigines, as opposed to 'wild blackfellows' or 'outsiders'. ${ }^{5}$ After colonisation, as the Aboriginal people assessed their situation, some resisted and fought for their land, and maintained that resistance; others adjusted to the prevailing white expansion by agreeing to work for the white man as a means of staying on their country. This reciprocal arrangement was sustained by the handing out of rations as the game and fruits

4 Cf. Dalziell 2002: 329, 338-339.

5 Tim Rowse, Bain Attwood and Robert Foster are among the historians who have written on this developed symbiotic relationship between Aborigines and settlers: Rowse 1998: 204; Rowse 1987: 81-99; Rowse 1986: 179; Attwood 1999: 28, 30; Foster 2000: 3; cf. also Morphy and Morphy 1984: 464, 473-474; Rowley 1971: $10-11$. 
of their land were replaced by livestock and planted crops. Diane Barwick found that Aboriginal women 'were invariably eager to come to the stations, and subsequently stayed even when their menfolk wandered'. ${ }^{6}$ Although Katherine Kirkland briefly refers to 'wild' Aborigines in the hinterland of Geelong in the 1830s, most of the references to Aboriginal people in these chapters are to 'station Aborigines'. The dependence of the settlers on Aboriginal people on pastoral properties and the use of services supplied by them significantly influenced the white women's representations.

The insights gained through the close readings of women's writing contained here resonates with important themes in Aboriginal history, such as frontier life, cross-cultural friendships, and Christianising and civilising. Violent conflicts at the frontier are either explicitly referenced (Emily Cowl, North Queensland; Rose Scott Cowen, central western Queensland) or 'hidden' (Katherine Kirkland, Western District, Victoria; Mary McConnel, south-east Queensland). These episodes or silences add to the historical interpretation of cross-cultural relations in early contact, particularly between men. The women's accounts join other contemporary texts that refer to interracial violence ${ }^{7}$ and add to the work of later historians who have concentrated their research on specific regions: R H W Reece (New South Wales), Michael Christie (Victoria), Neville Green (south-west Western Australia and the Kimberley), Lyndall Ryan (Tasmania), Raymond Evans (Queensland) and Noel Loos (North Queensland). ${ }^{8}$ Others, such as Henry Reynolds, Andrew Markus, Bain Attwood, Richard Broome and, again, Raymond Evans have applied a wider lens to conflicts on the frontiers. ${ }^{9}$

While the dynamics of frontier violence form a backdrop to the narratives studied, the focus is on the interracial relationships of the six women, each of whom channelled their insights on Aboriginal people into their writing. Each writer offers a different perspective, requiring a different interpretation. They thereby add to the work of historians such as Ann McGrath, Bain Attwood, Marie Fels, Bob Reece and John Mulvaney, who have explored the 'co-operative and collaborative aspects of past colonial black-white relations' ${ }^{10}$

The analysis of these narratives also involves literary criticism and literary history. Because I had begun my studies in the English Department of the University of New South Wales at the Australian Defence Force Academy (before transferring to the School of History at The Australian National University), I

6 Diane Barwick 1974: 53.

7 For example, The Way We Civilise; Black and White; The Native Police; A Series of Articles and Letters Reprinted from the Queenslander, 1880; and George W Rusden's History of Australia (1883).

8 Reece 1974; Christie 1979; Green 1984, 1989, 1995; Ryan, L 1996; Evans, Saunders and Cronin 1993; Loos 1982.

9 Reynolds 1987, 1990, 1993, 1996; Markus 1974, 1994; Attwood 1999, 2003; Broome 2002 [1982], 2005, 2010; Evans 2003, 2004.

10 Russell 2001: 5. 
was directed towards investigating published narratives. In drawing together this collection of texts, I have been able to plot changing literary treatments of relations between white and black women on the frontiers. The resultant interdisciplinary approach - although the crags and pitfalls were sometimes tricky to manoeuvre - has enriched the investigation, opening a wider field for further scholarly analysis and investigation. In the chapters on Eliza Davies and Emily Cowl in particular, I have situated the texts in their wider cultural context and within relevant discourses and genres, from where the representations of Aborigines can be viewed in terms of generic conventions, audience expectations and shifting racial attitudes.

During the 1980s and 1990s the literary genre investigating the lives of colonial Australian women consisted largely of the publication of letters and diaries, often presented as anthologies or accompanied by commentary. These included the works of Patricia Clarke, Dale Spender, Fiona Giles, Lynne Spender, Debra Adelaide, Elizabeth Lawson and Lucy Frost. The Letters of Rachel Henning, first published by The Bulletin in 1951-52, and Annabella Boswell's Journal: An Account of Early Port Macquarie (1965) were earlier publications in this genre. These studies form a foundational body of work about colonial women's experiences.

Since the 1970s historians have become aware of the need to write women, particularly Aboriginal women, into colonial rural histories. Anne Allingham regretted not adding women or Aborigines to the "male dominant squatting record' of North Queensland. ${ }^{11}$ In 1985, Marilyn Lake and Farley Kelly observed that: 'Perhaps the most consistently invisible women in conventional historical accounts ... have been Aboriginal'. ${ }^{12}$

Some of the historians who have addressed the subject of black-white female relationships between 1981 and 1993 are Patricia Grimshaw, Ann McGrath, Kay Saunders, Lyndall Ryan and Lyn Riddett. ${ }^{13}$ Historical, literary and anthropological studies, however, have tended to endorse the 'accepted versions $^{\prime 14}$ that white women were exploitative in their attitudes towards black women, or have chosen to focus on interracial female relationships which centred on shared outdoor activities, such as bush walks, Indigenous food foraging trips or swimming expeditions to the river or waterhole. Literary scholar, Helen Thomson identified this form of relationship with her comment that:

\footnotetext{
11 Allingham 1977: 221.

12 Lake and Kelly 1985: viii. Jan Pettman's study into 'intersections or race, ethnicity, class and gender' supports this statement, Pettman 1992: vii, 18.

13 Grimshaw 1981; Ryan 1986: 35-43; McGrath 1989; Saunders 1991: 157-160; Lake 1993: 377-386; Riddett 1993: 73-92.

14 Ferres 1993: 3.
} 
[White women's] sense of sisterhood with black women, imperfect though it may be, was expressed most powerfully through a shared, benign relationship with the natural world, in contrast to the exploitative violence of men. ${ }^{15}$

In Kay Saunders and Raymond Evans' Gender Relations in Australia (1992), Mary Anne Jebb and Anna Haebich threw out a challenge to understand 'fully' gender relationships on the frontier; and Jackie Huggins and Thom Blake lamented the comparative lack of studies by academic historians on interracial female relationships, while citing the growing body of work of Indigenous women writing about their own experiences. ${ }^{16}$ In 2005 Anna Cole, Victoria Haskins and Fiona Paisley's Uncommon Ground: White Women in Aboriginal History contributed to this latter genre. ${ }^{17}$

Patricia Grimshaw and Julie Evans in 1996 wrote of the 'injustice towards Aborigines ... involved in the process of settlement', seen in the writing of Rosa Campbell Praed, Mary Bundock and Katie Langloh Parker. Within what they described as the 'fragmentary alternative readings that contested aspects of the dominant colonial discourse', Grimshaw and Evans sought and found instances of Indigenous agency and authority. ${ }^{18}$ With Ann Standish, they wrote again in 2003 about Katie Parker's work, describing it as 'some of the few available sources of understanding Aboriginal women's experiences of colonization' within 'the paucity of sources on Aborigines coexisting with colonizers in the outback'. My study transcends the 'reciprocity and negotiation' operating between Parker and the Yuwalaraay women ${ }^{19}$ to reveal the dynamics of crosscultural associations between individuals.

Anthropologist Myrna Tonkinson in 1988 had bewailed the fact that there was 'surprisingly little detail in the literature on relationships of any kind between [black and white] women', other than those of individual settlers and an undifferentiated group of Aborigines ('natives'). She called for researchers to 'discover and explain evidence for and against relationships of sisterhood', which she defined as 'friendship based on equality' between Aboriginal and white women, particularly one-to-one relationships. ${ }^{20}$

Because of an assumed imbalance of power between black and white women in colonial settings, examples of affinity and equality between individuals have been hard to find. However, the memoirs of my three 'settlers' provide examples of close black-white female connections. Specifically, the relationship between

15 Thomson 1993: 35-36. Cf. Dawson 2002.

16 Jebb and Haebich 1992: 30, 53, 56-57.

17 Cole, Haskins and Paisley 2005. Cf. also McKellar 1984; Labumore 1984; Curthoys 1993: 169-170; Nelson,

Smith and Grimshaw 2002.

18 Grimshaw and Evans 1996: 81, 95.

19 Evans, Grimshaw and Standish 2003: 18, 31-32.

20 Tonkinson 1988: 39. 
Rose Scott Cowen, the sixth of my selected writers, and an Indigenous woman, 'Minnie', (albeit in the early years of the twentieth century) conforms to Sandra Lynch's defined characteristics of the necessary conditions and pleasures of friendship as 'toleration of difference' and '[s] hared activity, similarity of interest and of values and reciprocal services'.$^{21}$ This key example of interracial female friendship helps remedy the previous deficiency.

Kay Saunders plaint in 1991 was that 'no real understanding of the complexity of Australian history can emerge until question of the interrelationship of race, class, gender and region are systematically addressed', because '[u]ntil then all women will remain white and Black women will exist on the margins' ${ }^{22}$ This book goes some way in filling this gap.

The analyses of these six women writers contribute to the debate about history and fiction that has taken place between historians, literary scholars and creative writers. As Inga Clendinnen observes, it is necessary for writers dealing with the past to 'get inside episodes' in order 'to understand our subjects' changing motivations and moods in their changing contexts' ${ }^{23}$ This is no easy matter. Tom Griffiths, Kate Grenville, Alex Miller and Mark McKenna have all grappled with the question of how historians and creative writers can access the past through different forms of evidence, and how they can present their interpretations of past happenings through forms of representation, including writing.

Another consideration in play in my chosen narratives is the role of memory and its manipulation, a device investigated by Paula Hamilton. Robert Foster, Rick Hosking and Amanda Nettelbeck have discussed it in relation to the creation of silences that transformed the killing of Aborigines into benign - or comparatively innocent - encounters. ${ }^{24}$ In my selected texts, the time that lapsed between experience and publication influenced the women's representations, which were presented to fit changing social and racial attitudes and therefore audience expectation. Again, the role of storytelling - in Ann Curthoys' words, 'history's divided identity' ${ }^{25}$ _ also forms part of this debate. As 'life stories', presented as historical occurrences, these writings require a textual reading of their literary representations within the historical analysis.

While 'place' was not a criterion in my selection of the works, it was an important feature in the women's narratives. Five of them - the exception being Eliza

\footnotetext{
21 Lynch 2005: 76-77.

22 Saunders 1991: 160.

23 Clendinnen 2003: 287.

24 Hamilton 1994: 12; Foster, Hosking and Nettelbeck 2001: 1-2, 139; cf. also Richards 1925: 104, 106; Murphy 1986.

25 Curthoys 1997: 222. Cf. also, Curthoys and McGrath 2000: 1-13, 45-53; and Gunson 2002: 224-225. Many settler and Indigenous histories rely on reminiscences and storytelling as tools to evaluate and elucidate the past, cf., for example, Attwood and Magowan 2001.
} 
Fraser, whose focus was on her own sad plight - wrote about their surroundings. The representation of landscape in four of the writers contained literary tropes that informed and reflected their racial perceptions. Rose Cowen, the only Australian-born writer, was the exception. As the women's attitudes to the Australian landscape were associated with their attitudes towards Aborigines, Cowen's Australian birth and her love for the Australian countryside seemed to be allied to her different perspective of Indigenous people.

These texts are examples of 'women's' evidence that can add to and enrich the ever emerging picture of life on the Australian frontier. They help break 'the great silence about Australian colonialism' ${ }^{26}$ to offer new reinterpretations of frontier relationships. Except for Eliza Fraser, the women were writing for women, who made up a large percentage of the reading public. They write about their hardships and their coping strategies; they reflect women's interests and present the context of their life from a woman's viewpoint. The writers divulge small, private details of their everyday lives that, in the case of the settlers, included the intricate exchanges that take place between women, often recorded by way of reproduced dialogue. As the three chosen settlers were isolated from their white contemporaries, the women they drew close to were the Aborigines.

My 'primary' sources, then, are the autobiographical works of women, who wrote about - or, in the case of Eliza Fraser, recited - their colonial experiences of Aborigines. Although four of my authors published their work long after their frontier experiences, three of them (Eliza Davies, Emily Cowl and Mary McConnel) depended on diary notes to which they referred either directly or indirectly; McConnel reproduced entries from her diary into her text. Two others, Eliza Fraser and Katherine Kirkland, recorded their experiences soon after the events they discuss - Katherine Kirkland's letters to her mother are thought to have been her primary source. While not referring to the use of notes, the sixth woman, Rose Cowen, who lived most of her life in outback Queensland, has dipped into a wellspring of information about people and places that she knew well.

A short précis of the current colonial racial attitudes and the nineteenth-century utilitarian urge to 'educate' precedes the study. It involves discussion of the influences during the nineteenth century of the Enlightenment idea of 'man's place in nature', of evangelical Christianity and the role of underlying notions of race based on scientific theories. All these aspects inform the women's works in some way. Chapter 1 discusses this conceptual base, from which the women have translated their experiences into textual form.

26 Evans, Grimshaw and Standish 2003: 31-32. Anthropologist W E H Stanner first coined the term 'The Great Australian Silence' when he used it as the title of his second 1968 ABC Boyer Lecture. 
In Chapter 2, the well-known story of Eliza Fraser and her iconic captivity tale act as the precursor to the analysis of the following five texts. Shipwrecked in 1836 off the now Queensland coast, she was rescued and supported by the Ka'bi people of Fraser Island, until found and returned to white settlement. Recent scholarship has identified Aboriginal behaviour and motives towards the survivors as benign - even succouring - but seen by a white, middle-class woman in 1836 as 'cruel'.

The Eliza Fraser saga has a lot to account for, notwithstanding that it was a product of its time. It was a story far too exciting, and with far too many opportunities to extrapolate, than one that might explore a truth, or merely present facts. When Eliza Fraser gave her report on her 52 days spent with the Ka'bi people of Fraser Island and the nearby mainland, she opened a can of worms. On 6 September 1836, after two weeks of recovery from debilitation and exposure, she dictated an account of her ordeal to a clerk of Foster Fyans, captain of the 4th Regiment and commandant at Moreton Bay. She was still exhausted, frail and disoriented, and she could not have known the influence her words would have on later commentators. Relatively balanced and reasonable compared with subsequent interpretations, her story was soon embellished and distorted, to be aided and abetted by Eliza herself.

Eliza's initial report reflected the misunderstandings that abound when individuals from different races meet for the first time. This was particularly the case when British people first encountered the indigenous inhabitants of the Australian continent. In Eliza Fraser's case, extenuating circumstances, even at the time she told her tale, heightened her distress and increased her complaints that she sustained 'cruel abuse' at the hands of Aborigines.

The five women, who later presented for publication reminiscences of their experiences with Indigenous Australians, grappled with the dichotomy of stereotypical notions of Aboriginal 'savages' of the sort that Eliza Fraser's story fed upon, and the reality of kindly, cooperative and helpful co-inhabitants of the land on which they lived. Racial attitudes were mollified and modified on closer contact with Aboriginal people.

Chapter 3 looks at the work of Eliza Davies (formerly Arbuckle), who published in 1881, The Story of an Earnest Life: A Woman's Adventures in Australia and in Two Voyages Around the World. A clever and enterprising woman, Davies had her eye on producing an exciting story involving ugly savages. Emigrating from Scotland in 1838, she moved to South Australia where, as the servant of the explorer Charles Sturt's family - a position heavily disguised in her book - she accompanied Sturt and the South Australian governor, George Gawler, on an exploration of the Murray River in November to December 1839. In the chapter covering this adventure, she describes Aborigines as bestial and malignant. 
She inadvertently, however, also depicts the cordial welcoming, reciprocity, curiosity and humour of the Ngarrindjeri and Meru people. Elsewhere in her text, she presented a dispassionate, sympathetic and realistic view of Indigenous Australians. A devoted reader of the works of Sir Walter Scott, she may well have applied the words from Scott's Marmion to her own writing: 'Oh what a tangled web we weave, When first we practise to deceive!'.

Chapter 4 deals with Mrs T Holder (Emily) Cowl, who lived in the frontier town of Normanton near the Gulf of Carpentaria from August 1871 to March 1875, while her husband was setting up the Normanton telegraph station. Initially telling her tale to the members of a Pioneers Club in Brisbane, she published her two lectures in about 1912 as Some of My Experiences during a voyage to the Gulf of Carpentaria and three years' residence at Normanton in the early Seventies. As a town-dweller, Emily did not forge a close connection with the Kurtjar people and expressed an antagonism towards them, conforming to the expectations of her audience. Seemingly hoping to entertain, she concocted a boys' own annual, 'ripping yarn' style of narrative to describe the sort of escapade, popular in adventure narratives from the late nineteenth century. In it the Kurtjar were posed as the dangerous enemy. Emily, however, also included in her text the Aborigines' ingenuity and their humorous reactions to the white interlopers.

In Chapter 5, I look at the work of Katherine Kirkland, whose 'Life in the Bush' was first published in serialised form in 1842, in Britain. Writing of the same period as Eliza Davies, Katherine settled from 1839 to 1841 on a pastoral property in what is now the Western District of Victoria. Unlike Davies, she published her memoirs soon after her colonial experiences. Hiding behind her authorial title - 'a Lady' - Katherine was wary of divulging how close she had come to the Indigenous owners of her land, or of how much the Aboriginal women had helped her in the first months of settlement. Before she could plant a vegetable garden or form a dairy, Katherine had to somehow provide sustaining food for her husband, her brother and up to four workers, as they built huts and established a sheep station. She also had a two-year-old daughter and was in the early months of pregnancy. Although Katherine tried hard to maintain her silences, glimpses of the help she received from the Moner balug women peep through. She also recorded valuable insights into the culture and character of the Wathaurong people before their rapid demise in the wake of settler incursion.

The reminiscences of Mary McConnel, another settler woman, fill the pages of Chapter 6. Mary's aim is to Christianise and civilise the Dungibara people, who shared the land where David McConnel had established his Cressbrook estate. As the wife of a wealthy pastoralist, who in 1841 had become the first settler in the upper Brisbane River valley, Mary's sense of superiority is firmly in place. 
Yet she generously replicated the words of some of the Dungibara women when they proudly voiced their ownership of the land, or seemingly mocked the white woman's strange customs.

Chapter 7 deals with the only one of the six women that was Australian-born. Rose Scott Cowen (born Hamilton) grew up on the central western Queensland property, Tambo. After her marriage in 1900, she lived for 11 years in the Channel Country in far western Queensland. Writing later than the other women, and less bound by British middle-class conventions, Rose Cowen spoke openly of Indigenous morality, integrity, dignity and kindness.

A note on referencing. For ease of reference the works of the six women authors are placed separately in Appendix A. Similarly, Appendix B holds works of other Australian women mentioned in the text. The bibliography contains all other references cited in the work. Footnotes are set out with the first citation of a reference in full for works held in the appendices and also for archival and primary references. Subsequent citations are abbreviated to author date with references in the appendices including an abbreviated title. Secondary references are cited as author date.

Finally, a word about my own interpretative stance: As E D Hirsch observed, 'Every act of interpretation involves ... at least two perspectives, that of the author and that of the interpreter' ${ }^{27}$ The most significant influences of which I am conscious are my regret, as a non-Indigenous woman, for violence against Aborigines during the nineteenth century; and my recognition of the essential equality of all people whatever their race or social class. 



\section{Sowing the Seeds for Nineteenth- century and Early Twentieth-century Women's Writing}

The British, secure in the knowledge that they belonged to the world's greatest empire, considered themselves superior to native peoples in culture and understanding. This perception was bolstered by prevailing nineteenth-century attitudes and theories.

\section{Science and race}

Scientific racial theories about the place of humans in nature proliferated during the nineteenth century. The polygenist view, espoused by the social philosopher David Hume in 1742, was that there were different species of humans, exhibiting different characteristics, but all inferior to the white race. ${ }^{1}$ The monogenist idea was of a chain of being, linked in a one-dimensional natural progression from simplest animal to humans, originating from Aristotle's scala naturae. The publication of Charles Darwin's On the Origin of Species, available for sale in Sydney just four months after its publication in Britain in $1859,{ }^{2}$ resolved tensions between the monogenist and polygenist interpretations of human descent by affirming human unity, yet explaining racial diversity by relegating 'savages' to 'ape' status. ${ }^{3}$

Darwin had been formulating his theories of biological adaptation during his five-years voyage on the Beagle to South America and the Pacific Islands, from which he returned to Britain in 1836. In the 1872 edition of his Origin of Species, Darwin introduced the phrase 'survival of the fittest' - a term which Social Darwinists applied to the idea of victory by the strongest (organism or race) as a necessary condition for progress. Barry Butcher suggests that Darwin formed his views of race from his 'observations and experiences' during his visit to Australia in 1836 and was influenced by the 'scientific and exploration literature' emanating from this country. At this time Darwin mooted that the 'mechanism of natural selection might apply in the case of human beings' ${ }^{4}$

\footnotetext{
1 David Hume, 'Of national characters', in Essays: Moral, Political, and Literary, Scientia Verlag Aalen, Germany, 1964: 252, 244, 250, 249.

2 Charles Darwin, The Origin of Species By Means of Natural Selection or The Preservation of Favoured Races in the Struggle for Life, Claremont Classics, Australia, 1999 [1859]; Butcher 1999: 39.

3 Howard 1982: 10-19; Darwin 1999 [1859]: 17-25.

4 Butcher 1994: 380.
} 
Darwin's theories were strenuously debated in the Australian colonies. ${ }^{5}$ Mark Francis has pointed out that their application in Australia was varied and idiosyncratic, and dependent on interpretation. Prevalent, however, was the condoning of '[c]onquest and the takeover of Aboriginal lands', based on the belief that Aborigines were at the lowest level of humankind, a 'lost cause', unable to be civilised, and their culture 'primitive and destined to disappear' ${ }^{6}$ As these ideas could be applied to Darwin and Alfred Russel Wallace's 1859 evolutionary theories, they were reiterated and accepted as being scientifically valid. ${ }^{7}$ This conveniently served the interests of British pastoralists in Australia where the acquisition of land was paramount.

Contributors to the post-Darwinian discussion in Australia were the anthropologists Lorimer Fison, Alfred William Howitt, (Sir) Baldwin Spencer and Francis Gillen. Evolutionary theorists Thomas Huxley, J Lubbock (Lord Avebury), E B Tylor, Sir John Evans, A L Pitt-Rivers, L H Morgan, J F McLennan, Sir James Frazer and Andrew Lang all joined the debate. Findings from anthropological fieldwork were published in works such as Fison's Kamilaroi and Kurnai (1880) and Spencer and Gillen's The Native Tribes of Central Australia (1904). ${ }^{8}$

\section{'A book is a version of the world' (Salman Rushdie)}

Because education was more freely available for girls during the nineteenth century, reading became a popular pastime for middle-class women. Unable to participate in politics, business or financial administration, and excluded from the leisure pursuits of men, such as hunting and drinking, women turned to reading books. The predominant evangelical social climate forbade theatre going, dancing, music halls or even card games, but reading was encouraged as a means (together with prayer and moral purity) of attaining spiritual fulfilment. ${ }^{9}$ As reading flourished in Britain, public libraries increased in number: by 1838 there were also 38 circulating commercial libraries within three Westminster parishes. $^{10}$

Current scientific theories and the accounts of Englishmen observing or meeting members of the black races, and, seeming to cast them to inferior racial

5 Cf. Butcher 1988: 153-169.

6 Francis 1996: 90-105; Anderson and Perrin 2007: 26-27; Butcher 1994: 374.

7 Charles Darwin and Alfred Russel Wallace, Evolution by Natural Selection, Published for the XV International

Congress of Zoology and The Linnean Society of London, Cambridge University Press, Cambridge, 1958.

8 Mulvaney 1990: 24-42.

9 Altick 1957: 85, 86, 141, 99; Watt 1963: 45.

10 Brewer 1997: 177-180; Altick 1957: 217. 
positions, were therefore available to the women of this book-five of whom were born in Britain, the sixth classically educated on a pastoral property in central western Queensland. In the Australian colonies, racial theories that cast Aborigines to the lowest level of humankind were reiterated and accepted as being scientifically valid.

Other books, however, were also available. History and travel books were popular, particularly tales of seafarers and their adventurous voyages. Into this category sneaked Daniel Defoe's Robinson Crusoe, a book that challenged Pilgrim's Progress as the British public's most popular book. James Cook's Voyages joined these two to become in 1849 the trio of the most frequently borrowed books from English public libraries. ${ }^{11}$

William Dampier's A New Voyage Round the World, published in 1699, was an early best-seller, as were his later books, Voyages and Descriptions (1699), which dealt with his second voyage to the western Australian coast, and A Voyage to New Holland (in two parts, 1703 and 1709). Dampier's description of Aboriginal people from his first visit in January 1688 - thought to be the Bardi people from the area around Derby, Western Australia - set the scene for later depictions of 'savages' or 'odd' people in outlandish places, including Defoe's Robinson Crusoe (1719) and Jonathan Swift's Gulliver's Travels (1726). Because Dampier was an eyewitness, his 'factual' accounts replaced earlier vague and fantastical ideas of the sort reproduced onto navigational maps of the Southern Seas. His account described the Aborigines as:

the miserablest People in the World ... [differing] but little from Brutes. They are tall, strait-bodied [sic], and thin, with small long Limbs. They have great Heads, round Foreheads, and great Brows. Their Eye-lids are always half closed to keep the Flies out of their Eyes ... They have great Bottle-Noses, pretty full Lips and wide Mouths. The two Fore-teeth of their Upper-jaw are wanting in all of them, Men and Women, old and young ... They are long-visaged, and of a very unpleasing Aspect, having no one graceful Feature in their Faces. Their Hair is black, short and curl'd, like that of the Negroes ... The Colour of their Skins, both of their faces and the rest of their Body, is Coal-black, like that of the Negroes of Guinea. ${ }^{12}$

A study by Diana and Michael Preston of the unpublished draft of $A$ New Voyage has identified differences between Dampier's journal notes and the final publication. Consistent with his recognised objective style of observation, Dampier in his journal described the Aborigines as being 'of good stature but

11 Williams 1961: 158-159; Altick 1957: 258, 126, 220.

12 William Dampier, A New Voyage Round the World, Adam and Charles Black, London, 1937 [1697]: 312-

313 (italics in original). A version can be found in Flannery 1998: 8. 
very thin and lean', a condition which he attributed to 'want of food'. Their hair was 'matted-up like a negroe's' for 'want of combs'. The Prestons suggest that the inclusions of the emotive expressions 'Brutes' and 'unpleasing Aspect', which were not recorded in Dampier's journal, may have been included either by Dampier or his publisher to embellish the truth by sensationally augmenting the idea of Indigenous 'savagery', in the interest of an increased readership. ${ }^{13}$ The inclusion of racial stereotypes to sell books is evident in some of the autobiographies dealt with in this book.

James Cook's 1770 interpretation of Australia's Indigenous people followed JeanJacques Rousseau's Enlightenment concept of the 'noble savage'. Cook adopted the notion that noble savages lived a virtuous and happy life in harmony with natural laws. He wrote that the Aborigines were 'far more happier than we Europeans', living tranquilly without unnecessary possessions or the struggle of class hierarchy, in a temperate climate with unspoiled air. ${ }^{14}$

Joseph Banks' assessment, on the other hand, bears the strong influence of Dampier. In the Endeavour Journal, ${ }^{15}$ Banks assessed Aborigines as subjects to be analysed and categorised. Recently elected a Fellow of the Royal Society, he published his journal from the Endeavour voyage with Cook soon after his return to England in 1771, motivated by the growing utilitarian impulse for the 'advancement of useful knowledge' ${ }^{16}$ Deferring to Dampier's descriptions as a yardstick by which to assess Indigenous skin colour, Banks wrote that he saw through his binoculars, '5 people who appeard [sic] ... to be enormously black: so far did the prejudices which we had built on Dampiers [sic] account influence us that we fancied we could see their Colour when we could scarce distinguish whether or not they were men'. Subsequent entries strove to qualify and refine Dampier's observations, while continuing to underline Aboriginal differences in skin colour, habits and behaviour from civilised, refined white men. ${ }^{17}$

Banks' depiction included moral judgements. He stressed the primitive nature of Aborigines, describing them as 'coverd [sic] with their filth which I beleive [sic] they never wash of'. He stated that the dirt on their bodies seemed 'to have stuck to their hides from the day of their birth without their once having attempted

\footnotetext{
13 Preston and Preston 2004: 175.

14 Harrison 1998: 193-194; Smith 1985: 86, 87, 102, 169. In accordance with nineteenth-century patriarchal values, noble savagery usually applied to Aboriginal males who encapsulated the English Victorian value of 'manliness' in their tall, straight, healthy bodies, masculine energy and physical power, Reader 1974: 188; Gibson 1984: 183.

15 J C Beaglehole (ed.), The Endeavour Journal of Joseph Banks 1768-1771, Volume II, The Trustees of the Public Library of New South Wales in association with Angus and Robertson, Sydney, 1962.

16 Jeremy Bentham introduced this concept into British mainstream thinking in 1789 with the publication of Introduction to the Principles of Morals and Legislation. Moyal 1993: 10; Gascoigne 1994: 8-9.

17 Beaglehole 1962, Vol. II: 50, 55, 58.
} 
to remove it', thereby relegating Aboriginal people to an unenlightened and degraded status. Unable to detect any form of agricultural cultivation, he cast them to a rank 'little superior to that of monkies $[\mathrm{sic}]^{\prime} \cdot{ }^{18}$

Banks perceived Indigenous painted bodies and the 'uncouth' bone 'as thick as a mans [sic] finger and 5 or 6 inches long' through the nose as signifiers of savage aggression, underlining this image with a reference to their brandishing spears and boomerangs at the Europeans in what Banks interpreted as a menacing act. ${ }^{19}$ On his return to England, his racially slanted observations were readily accepted by the scientific community, and were freely available to the female reading population.

Like the women in this book, Watkin Tench discovered that an initial impression of Aborigines could change on closer acquaintance. A captain-lieutenant in the marines and official scribe of the first four years of British settlement at Port Jackson, Tench shows how an intimate understanding of Aboriginal individuals can change racial attitudes. In Sydney's First Four Years: A Narrative of the Expedition to Botany Bay (1789), ${ }^{20}$ he reiterated the derogatory racial attitudes of Dampier and Banks; disparaged Indigenous workmanship, except their skill in weaving - a trait which became stereotypically associated with Aborigines in the works of later colonial observers; criticised Aboriginal houses as 'rude in construction' and their canoes as being 'as despicable as their huts'. By implication, he deemed Aborigines to be unintelligent because they had no comprehension of 'the use or benefit of cloathing [sic]', despite the fact that he had seen them 'shivering, and huddling themselves up in heaps in their huts, or the caverns of rocks, until a fire can be kindled'.$^{21}$

Well-educated and living some time in France, Tench rejected Rousseau's noble savage imagery, writing that:

Notwithstanding the disregard they have invariably shewn for all the finery we could deck them with, they are fond of adorning themselves with scars, which increase their natural hideousness. It is hardly possible to see any thing in human shape more ugly, than one of these savages thus scarified, and further ornamented with a fish bone struck through the gristle of the nose. The custom of daubing themselves with white

18 Beaglehole 1962, Vol. II: 112, 123-124.

19 Beaglehole 1962, Vol. II: 91, 92-93, 53.

20 Tench's journals have been published in, Captain Watkin Tench, Sydney's First Four Years: A Narrative of the Expedition to Botany Bay and A Complete Account of the Settlement at Port Jackson 1788-1791, introduced and annotated by L F Fitzhardinge, Library of Australian History in association with the Royal Australian Historical Society, Sydney, 1979

21 Tench 1979: 47, 48. 
earth is also frequent among both sexes: but, unlike the inhabitants of the islands in the Pacific Ocean, they reject the beautiful feathers which the birds of their country afford. ${ }^{22}$

In A Complete Account of the Settlement at Port Jackson (1793), however, Tench's closer knowledge of the Darug ${ }^{23}$ people had changed his attitude to expose an appreciation of the universal human need for body decoration. He wrote:

Unsatisfied ... with natural beauty, like the people of all other countries, [the Darug] strive by adscititious [supplementary] embellishments to heighten attraction, and often with as little success. Hence the naked savage of New South Wales, pierces the septum of his nose, through which he runs a stick or a bone; and scarifies his body, the charms of which increase in proportion to the number and the magnitude of seams, by which it is distinguished. The operation is performed by making two longitudinal incisions, with a sharpened shell, and afterwards pinching up with the nails the intermediate space of skin and flesh, which thereby becomes considerably elevated, and forms a prominence as thick as a man's finger. No doubt but pain must be severely felt, until the wound be healed. But the love of ornament defies weaker considerations: and no English beau can bear more stoutly the extraction of his teeth, to make room for a fresh set from a chimney sweeper; or a fair one suffer her tender ears to be perforated, with more heroism, than the grisly nymphs, on the banks of Port Jackson, submit their sable shoulders to the remorseless lancet. ${ }^{24}$

Tench's description of Arabanoo, a young Darug man who had been forcibly captured during the first years of colonisation, demonstrated his growing understanding of Aboriginal individuality. He depicted not only the physical beauty of Arabanoo's robust body but also his 'gentleness and humanity', his 'vivacity and good humour' and his disgust at the inhumane practice of flogging. His appraisal of Arabanoo's physical and moral strength, his fine character and demeanour, complied with the nineteenth-century esteemed ideals of 'manliness and sensibility'. ${ }^{25}$

Women, as readers, had access to all these published theories and opinions. Unlike Hume, who had not seen Indigenous Australians, and Darwin, who had only superficial contact with them, women who lived among Aborigines over varying periods of time, could add to the accounts of previous writers with their own representations of Aborigines.

22 Tench 1979: 47, xxi, xvi.

23 I have adopted the name for the language group, used by Attenbrow 2002.

24 Tench 1979: 277.

25 Vance 1985: 1, 8; Tench 1979: 139, 143, 142, 145. 


\section{Evangelical Christianity}

By far the most influential book to the reading female population was the Bible. The Puritan aspect of religion had been fundamental to middle-class values since the seventeenth century. During the nineteenth century there was a resurgence of evangelical Christianity. Hugely popular were religious tracts, books on spiritual guidance and assurance, moralistic tales, autobiographies and didactic fiction. John Bunyan's Pilgrim's Progress and John Milton's Paradise Lost were two of the most read books, introduced to children as part of their regular Sunday devotions.

Forming the basis of nineteenth-century English morality, evangelicalism exerted an overriding influence on social and cultural values. It also promoted the idea of an 'elect people', justifying the accumulation of imperial wealth and power. Urged on by the creeds of industrialisation and progress, this perception was a principal element in imperial expansion, which encouraged attitudes of racial superiority, backed by cultural arrogance.

As the evangelistic urge to extend the Christian empire spread across the world during the first half of the nineteenth century, belief in God's call for 'improvement' encouraged the idea that racial differences in standards of civility and morality could be eradicated through the power of Christianity. Evangelists believed that by instruction and example 'uncivilised' people, who were different from the English in appearance, values, culture and behaviour, could be raised from ignorance to a level approximating (although probably never quite achieving) the superior status of English society and culture. The aim of civilising and 'cultivating' pagan savages was to be realised by the redeeming of their heathen souls through God's saving grace. ${ }^{26}$

\section{Middle-class respectability}

Another strong influence on nineteenth-century British women and their identity was the overriding power of the concept of 'class'. In Britain, genteel women differentiated themselves from the dissolute and irresponsible aristocracy and the feckless and irreligious urban poor. The middle class was usually defined as comprising property-owning groups engaged in manufacturing, trade and the professions. It was different from the aristocracy and gentry by virtue of active participation in the productive economy, and from the working class by abstention from manual wage labour. ${ }^{27}$

26 Cf. Marty 1970: 78-88.

27 Gunn 2000: 14-15. 
A British woman's identity was determined and judged by the way she looked and acted within class expectations. Respectable middle-class women adopted a form of genteel culture, described by Linda Young as 'a rigid structure of explicit and implicit rules'. ${ }^{28}$ Nineteenth-century perceptions of respectable womanhood involved decorous appearance and the 'civilised' behaviour of modesty, sobriety and adherence to strict Christian moral values. In extreme form, the adoption of Puritan sexual mores could result in undue propriety or prudery. Earnestness, 'duty', hard work, tidiness, thrift and respect for the law were esteemed attributes. ${ }^{29}$ These qualities were transposed even to the slab hut on remote colonial outposts. Because of the expected demands of gentility to maintain a respectable household, women strove to define the ideals of gentility by neatness, orderliness and cleanliness. Penny Russell has termed this behaviour the 'genteel performance' ${ }^{30}$ All the women writers in this book were (or espoused to be) members of the British middle class. Their core middle-class values slanted the way they viewed Aborigines.

Clothing was integral to maintaining a respectable appearance, serving to maintain a middle-class woman's position within the English class system. A 'refined' appearance not only identified her own status but also allowed her to identify other women of her class. It also nominated by implication her possession of the middle-class virtue, 'morality'. The stark difference between white, ornately clothed, controlled, Christian, civilised women and their binary opposite - black, naked, 'uncontrolled', heathen natives - fed into British racial assumptions that encouraged the stereotypical depiction of Aborigines as 'savage', 'ugly' and 'depraved'. Conversely, when Aborigines first clapped eyes on the over-dressed white women, their astonishment and curiosity often spilled over into hilarity or a quirky sense of fun.

Within the dynamics of the male power structure at the frontier, the investigation of the following female narratives offers another perspective on interracial relations. Despite the constraints on them of the middle-class code of respectability and the nineteenth-century's racial and religious concepts, the women began to replace racial clichés and stereotypes, and the literary imperatives to conform to an accepted view that editors and publishers often expected. As they grew to know Indigenous people as individuals, they revealed in their writing aspects of Indigenous humanity, agency and authority.

\footnotetext{
28 Young 2003: 189. Young explains that, behind this facade, there was a fluidity that enabled aspirants to join the middle class.

29 Samuel Smiles extolled middle-class virtues in his numerous publications, e.g., Self-Help: With Illustrations of Conduct and Perseverance (1859), Character (1871), Duty: With Illustrations of Courage, Patience and Endurance (1880), Thrift (1875). By 1953, Self-Help had been reprinted 71 times.

30 Russell 1994: 58-59. Cf. also, Russell 2010: 26.
} 


\section{Part A}

\section{Adventurers}





\section{Early Perceptions of Aborigines- Eliza Fraser's Legacy: 'Through a Glass Darkly'}

'At the outset we promised to render the history subservient to the cause of morality, and we trust that we have performed our promise.'

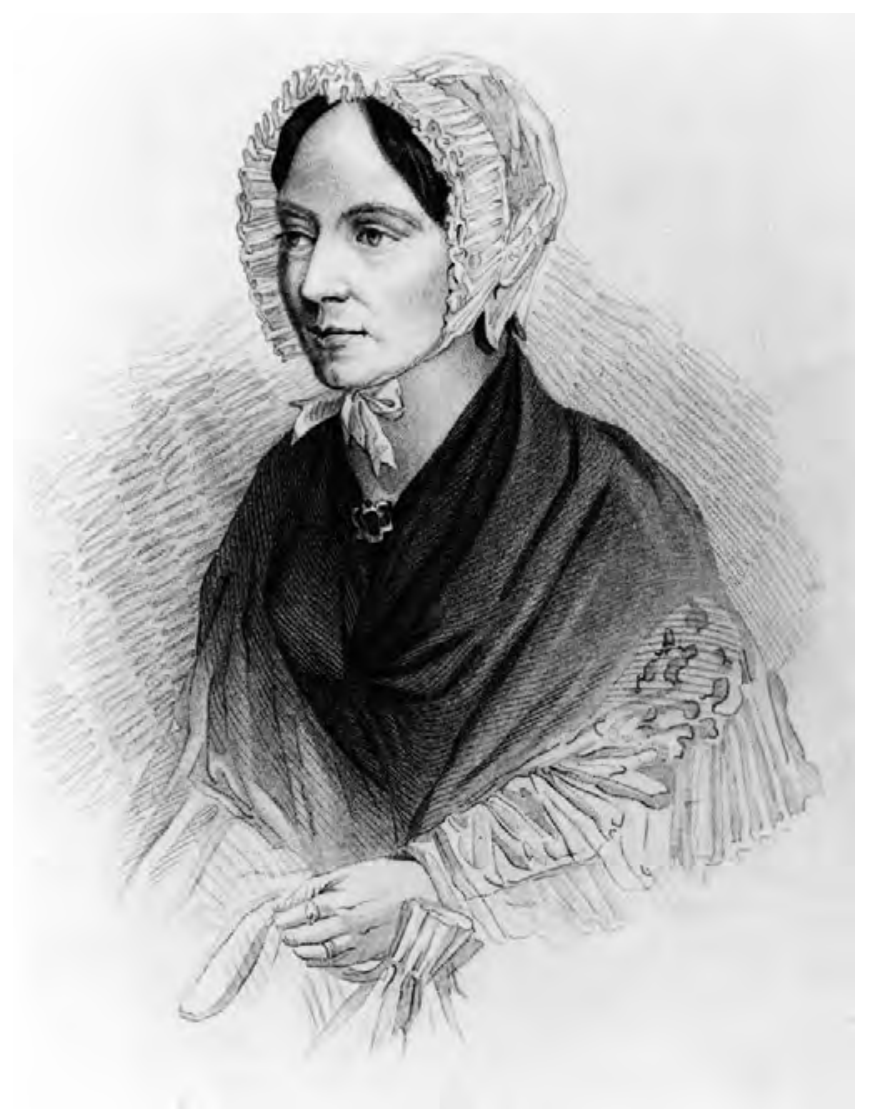

Illustration 1. Engraving of Eliza Fraser.

Source: John Curtis, The Shipwreck of the Stirling Castle, George Virtue, London, 1838.

\footnotetext{
1 John Curtis, Shipwreck of the Stirling Castle containing A Faithful Narrative of the Dreadful Sufferings of the Crew, and the Cruel Murder of Captain Fraser by the Savages. Also, The Horrible Barbarity of the Cannibals Inflicted upon The Captain's Widow, Whose Unparalleled Sufferings are Stated by Herself, and Corroborated by the Other Survivors. To Which is Added, The Narrative of the Wreck of the Charles Eaton, in the Same Latitude, George Virtue, London, 1838: 375.
} 


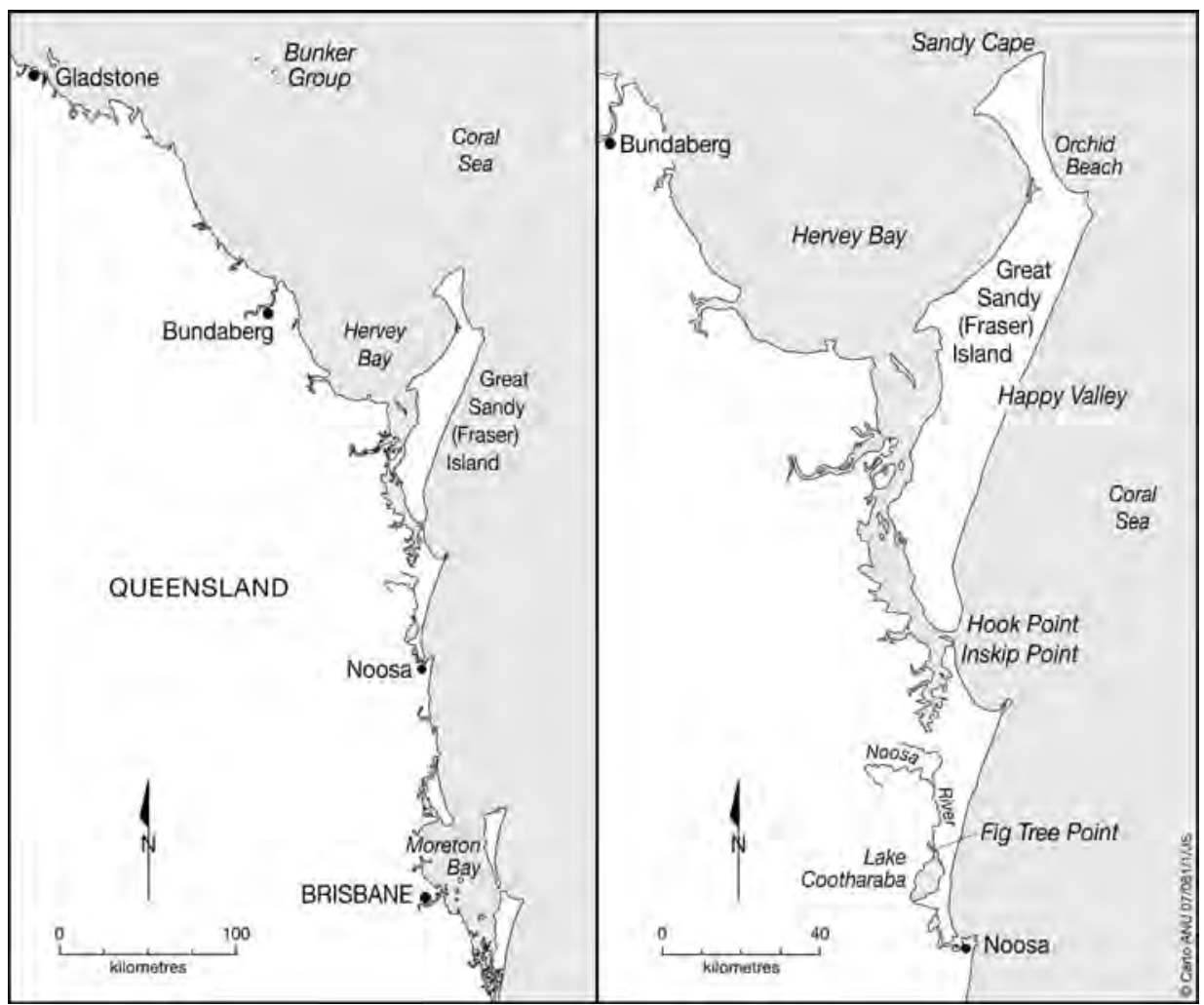

Map 2. Eliza Fraser. South-east Queensland coast showing location of Fraser Island and on the right detail of the immediate Fraser Island area.

Source: CartoGIS, College of Asia and the Pacific, ANU.

\section{The role of Eliza Fraser}

As the first white woman to meet Aborigines and to tell her tale, Eliza Fraser's story was bound to have an impact. It has become a famous, archetypal encounter between a white woman and Australia's Indigenous people and, from its earliest days, it was a powerful and influential tale that helped generate fear and prejudice about Aborigines and the frontier. Her tale of shipwreck on 21 May 1836, her 52 days with the Ka'bi people and her subsequent 'rescue' and return to white settlement on 22 August 1836 became so well known and so thoroughly worked over, that women writing later could not help but be influenced by it.

As an early example of colonial storytelling at work, particularly about white women and Aborigines, Eliza's story encapsulated the dread of shipwreck and the frightening prospect of travellers falling victim to unknown, though presumably savage, peoples. This fear fostered a vigorous genre of captivity tales 
during the late eighteenth and early to mid-nineteenth centuries, particularly in the United States of America. While usually based on fact, such narratives were written to suit a readership seeking vicarious adventure, and often contained the religious motives of the author or publisher.

Eliza's story was so popular that her history has been refracted into a collage of tellings and re-tellings, of contradictions and conflicting interpretations, and through later appropriations into art and literature. ${ }^{2}$ It has been transposed from its origins as a story of survival from shipwreck to the status or myth and legend. The women who later wrote of their own encounters could not have been immune to the seduction of its sensationalism.

\section{Background and shipwreck}

Early biographical details of Eliza are sketchy. She was born Eliza Anne Slack, perhaps in Derbyshire, England, in about 1798. Her childhood may have been spent in Ceylon (Sri Lanka), but she lived at least part of her adult life in Stromness, on the Orkney Islands. Here in 1835 she left her 15-year-old daughter Jane, and two sons, James (11) and David (six), in the care of the Presbyterian minister and set sail for Hobart Town on the brig Stirling Castle. Her ailing, 56-year-old husband, James Fraser, was its captain. ${ }^{3}$

On the return voyage, the Stirling Castle left Sydney with a crew of about 17 men; 11 or 12 new seamen had joined the ship at Sydney, where most of the former crew had deserted. On the night of 21 May 1836, while sailing along the north-eastern Australian coast, the vessel struck a coral reef. All on board took to the two lifeboats that could be saved. Both however were damaged in the attempt and badly leaking.

The survivors headed south, hoping to reach the convict settlement of Moreton Bay. Captain Fraser, Eliza, the first officer, Charles Brown, and eight crew members were in the longboat, together with as many provisions as could be salvaged. Eliza, who was heavily pregnant, gave birth in the boat some time between shipwreck and landing, to a baby who subsequently died. In the lighter pinnace were the Second Mate John Baxter (James Fraser's cousin), the boatswain Edward Stone and the remaining five men.

2 Patrick White's A Fringe of Leaves (1976), and Sydney Nolan's series of paintings on Eliza Fraser (19471978) are two examples.

3 Elaine Brown, 'Fraser, Eliza Anne (c. 1798-1858?), Australian Dictionary of Biography, National Centre of Biography, The Australian National University, http://adb.anu.edu.au/biography/fraser-eliza-anne-12929/ text23361, accessed 25 January 2013. 
For about three weeks, the two boats sailed south, stopping at islands to repair their leaking boats, and to search for water. Their own supply had been consumed in the first week. Lasting longer was a quantity of brandy and 13 gallons (60 litres) of beer. The ensuing drunkenness encouraged mutinous self-confidence in some of the crew. After one more week at sea, the castaways saw smoke, and threatened to drown Fraser if he did not 'put in'. Although Fraser had not wanted to beach the boats unless entirely necessary, fearing that 'the blacks would murder them all', ${ }^{4}$ the boats landed.

Here the boatswain took charge of the pinnace and set sail with six of the youngest crewmen, having exchanged Baxter for the ship's boy, John Fraser (James Fraser's nephew). ${ }^{5}$ He planned to sail and row to Moreton Bay, 300 kilometres to the south. However, the men mistakenly bypassed Moreton Bay, coming ashore at the Tweed River, in present-day northern New South Wales. From this group, there was only one survivor, who was to be picked up by a passing ship at the Macleay River and taken to Sydney.

\section{On Fraser Island}

The longboat with the remaining castaways sailed south for another week. On about 12 June, it came to land on Great Sandy Island (now, Fraser Island), 30 kilometres south of Sandy Cape in the vicinity of the modern site of Orchid Beach. Some time after landing (Baxter cites one day; Eliza, ten days), six of the men started to walk southwards, taking with them Fraser's shotgun, pistol, muskets, ammunition, and some of his navigational instruments. Of this group, three arrived at Moreton Bay on 8 August 1836; one drowned while attempting to swim to the mainland; and two were rescued when Eliza was 'rescued'. Baxter was also to be found alive and well with the Aborigines. A total of eight passengers from the Stirling Castle was to survive the shipwreck.

It was now impossible to launch the longboat. Alongside her unarmed male compatriots, Eliza realised that she was 'totally defenceless' ${ }^{6}$ Fraser, Eliza, Brown, Baxter, and Michael Doyle, the only crewman who had remained loyal to his captain, began their own long walk south, starving, dehydrated, wet,

\footnotetext{
4 Barry Dwyer and Neil Buchanan, The Rescue of Eliza Fraser: 150th Anniversary Edition, Eliza Fraser Commemorative Committee, Noosa, Queensland, 1986: 35, 33.

5 Details are confusing and hard to piece together. I have attempted it by incorporating Eliza and Baxter's first written recollections. Eliza and Baxter's accounts differ in the timing of the parting of longboat and pinnace. Baxter reported that the pinnace was 'taken away against the Captain's orders', whilst the survivors were on 'Bunkers Islands'; Eliza's version is that it occurred after 'a week or ten days after leaving the Island'. As Baxter took part in the exchange of boat occupants, and as this exchange would have been difficult to perform at sea, Baxter's report seems to be the accurate one, Dwyer and Buchanan, Rescue of Eliza Fraser, 1986: 33, 35.

6 'Mrs Fraser's Narrative', Dwyer and Buchanan, Rescue of Eliza Fraser, 1986: 35.
} 
cold, and exhausted from lack of sleep after rowing and bailing out water from the boats. Eliza had had to cope with childbirth in a lifeboat, surrounded by men, including the crew, and the death of her child, perhaps in the water at the bottom of the boat. Despite these parlous and extraordinary circumstances, the focus of her three-month ordeal in later works is centred upon the mystique of the 52 days during which she lived amongst the Ka'bi.

The glare from the sun reflecting from the white sand is intense, even in July, and blinding for a woman from a far northern island of Scotland. It was intense enough to give Eliza severe sunburn on her shoulders where, when rescued, her 'tender skins hung in scales'. ${ }^{7}$ That said, the weather can also be bleak, even 'frostily cold', in winter. In July, strong cool to cold winds blow, whipping up sand. There were also numerous varieties of mosquitoes, sandflies and biting March flies on the island. ${ }^{8}$ This is the setting on which the Eliza Fraser story has flourished.

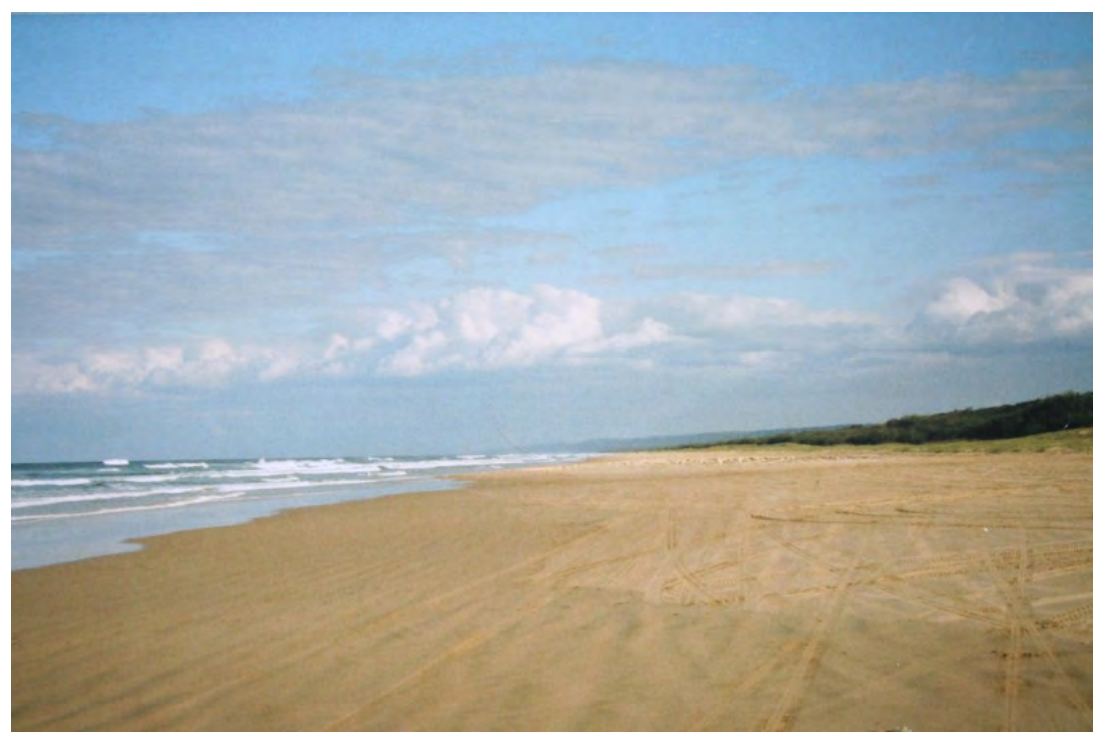

\section{Illustration 2. Ka'bi country: the long trek south, Fraser Island.}

Source: Barbara Dawson, July 2005.

7 'John Graham's Report', Dwyer and Buchanan, Rescue of Eliza Fraser, 1986: 31.

8 Queensland Naturalist: Journal of the Queensland Naturalists' Club, Vol. 19, November 1968: 47-50. I visited Fraser Island in mid-July 2005. Overnight rain fell and the temperature dropped to 8 degrees Centigrade. Maximum temperatures in winter are about 20 degrees Centigrade. 


\section{'Cruel abuse'}

While lacking the embellishments of Aboriginal barbarity found in later reconstructions, Eliza's accounts of her experiences are replete with cultural misunderstanding. ${ }^{9}$ Her first account, dictated in Moreton Bay on 6 September 1836, reflected her continuing debilitated state from three months' starvation and physical ordeals. On her return to the settlement on 22 August, she was emaciated, exhausted, weather-beaten, sunburned and disorientated. Although gently bathed, tended and nursed to a slight improvement in health by the ladies at the penal settlement, Eliza referred to Aboriginal 'cruelty', a term that corresponded with her indisposition from physical exposure, and exertion of a type to which a town-living woman would have been unaccustomed. This is evident in her emphasis of the forms of cruelty imposed on her, mainly the imposition of heavy manual work and the lack of protection from the elements. Weakened and ill, Eliza's lack of stamina had made her incapable of contributing to the tribal economy, and she had suffered accordingly.

Her summarised observations, recorded two weeks after her return to white society, also revealed the attitudes of a middle-class white woman, who has been asked by colonial government officials to tell her story. Her complaints about being induced to become naked, to undertake daily tasks of Indigenous life, and to find and subsist on predominantly bush tucker encapsulated the affront to her respectability, as well as reflecting the repugnance felt by civilised people towards Indigenous cultures. The use of the commandant's clerk to be her amanuensis calls into question her feelings at revealing the humiliating details of nudity and menial work. As a nineteenth-century woman who fell amongst 'savages', and lost her baby, husband and clothes, she would have needed to protect her virtue on her return to her own society; an aggrieved tone may have gone some way in redeeming her status. It is also possible that the male scribe may have introduced his own choice of words and suitable tone to the report. Whether the emphases came from him or Eliza, the brief account presented her ordeal in terms of racial affront with which her audience could readily identify. In addition, her self-portrayal as a victim, powerless in protecting herself and her companions, would have helped allay any hint of impropriety that might taint her respectable womanhood.

Unlike the various 'cruelties' that were later to pervade Eliza's account, her first encounter with the Ka'bi was tense but peaceful. She reported that:

9 Alan Atkinson has pointed out how mutual misunderstandings altered the humanitarian hope of Captain Arthur Phillip that relations with the Aborigines at Port Jackson in 1788 would be peaceful, Atkinson 2004: $145-167$. 
Directly we landed [on Great Sandy Island] the natives came down in crowds but were prevented at first from using any violence from the sight of our firearms. We procured some fish from them in exchange for articles of wearing apparel. ${ }^{10}$

While acknowledging that the Aborigines provided food for the starving castaways, Eliza presupposed Aboriginal violence, which she thought had been curbed only by the sight of European weaponry. A further assumption of brutality occurred during the next meeting with Indigenous people when,

The next day we met with a numerous tribe of natives who, finding us unarmed, took everything from us with the exception of the clothes on our backs, beating us severely at the least resistance; on one of these natives we observed a piece of Female dress which led us to enquire if any white people had been there before us. To which they replied by signs to the effect as far as we understood them, that a man, woman and child had been wrecked there and massacred. ${ }^{11}$

These presuppositions of savagery set the scene for exaggerated interpretations that were to follow. After this encounter, the stranded Europeans continued their walk along the beach '[hastening] day and night for two days without either food or water'. On the third day, at a place thought to be in the vicinity of the present resort of Happy Valley, 50 kilometres south of Orchid Beach, they saw another group of Aborigines. Eliza described the meeting, and subsequent events, in the following manner:

we then fell in with another tribe who stripped us perfectly naked and forced us to follow them into their camp. We were now portioned off to different masters who employed us in carrying wood, water and bark, and treated us with the greatest cruelty. With the exception of a small portion of fish which we but very seldom got, all we had to subsist upon was a kind of Fern root which we were obliged to procure ourselves in the swamps. ${ }^{12}$

Eliza was adopted into the Ka'bi; some men went with the Batjali (Butchala) people.

The formal tone of Eliza's report suggests a reworking, this time from colloquial speech to a version of prescribed conventional language. This again raises the possibility of the role played by the transcribing clerk in transmuting Eliza's

10 'Mrs Fraser's Narrative', Dwyer and Buchanan, Rescue of Eliza Fraser, 1986: 35.

11 'Mrs Fraser's Narrative', Dwyer and Buchanan, Rescue of Eliza Fraser, 1986: 36.

12 'Mrs Fraser's Narrative', Dwyer and Buchanan, Rescue of Eliza Fraser, 1986: 36. 
primary account with the Ka'bi into language chosen by the scribe. Whoever was in control of the narrative style, the essence of the account is one filled with British assumptions of class and race.

The misapplied term, 'masters', for example, demonstrates a class hierarchy, unconnected with Indigenous society. The apportioning to different 'masters' infers that the survivors were regarded as servants. This servile position is further evoked in Eliza's interpretation that the white interlopers were starved of food, and forced to perform menial tasks. The English Master-Servant Act of 1823 had supported and formalised the rigid class distinctions that characterised the hierarchical society of nineteenth-century Britain. To place Aborigines in the position of masters is a curious overturning of the British assumption of Indigenous people as racially inferior. In doing so, it added to the perceived 'insult'.

Twentieth-century anthropologists, Catherine and Ronald Berndt have pointed out the differences between European and Australian Indigenous societies. They identified the cooperative nature of Aboriginal society, which they found depended on the 'organisation of human resources'. The Berndts wrote that the autonomy of each societal group relied on the individual strengths of each person. In this grouping of 'skilled, semi-independent operators in a co-operative network', a lack of cooperation meant that 'survival [was] a hazardous and chancy business'. Each individual was 'dependant on others as those others depended on them'. The Berndts also observed that, because of 'complex arrangements of co-operation, this balancing of tasks and responsibilities and areas of authority, were too subtle for most of the European newcomers to envisage, or grasp'. ${ }^{13}$ Both Eliza's reports, and the commentaries and reconstructions that followed, failed to take into account her own inability to reach these Indigenous social standards.

Furthermore, on Fraser Island, different contingencies applied in midwinter from those in summer. The absorption of the Europeans into different Indigenous groups suggests that the Aborigines chose to share the burden that extra members of the group would impose on the viability of their society. On the other hand, the menial work that the adopted members were expected to perform was seen as an insult to civilised Britons, who regarded themselves as superior to black races. Later writers expanded on this apparent relegation to slave conditions to malign, judge and attack the Aborigines for their brutality and 'cruelty'. This apparent indication of their cruel intentions was embraced as another example of the savagery of black heathens.

13 Berndt and Berndt 1983: 81, 59, 42, 22; Berndt 1980: 36. 
The stripping naked of Eliza was a shocking concept for nineteenth-century British readers, perhaps the more so because for them clothing codes represented class respectability and racial identity. Proper dress was tied to British ideas of 'civilisation', as opposed to the lack of standards of savages, who presented themselves as black, naked bodies. However, John Graham, who found Eliza and brought her to Moreton Bay, had lived for six years amongst the Ka'bi and he knew of the Aborigines' dislike of a clothed white man. As 'Mootemu', Graham had taken an Indigenous 'wife', 'Mamba', whose embodied spirit he claimed for Eliza in his successful attempt to return her to white society. Graham took into account Indigenous fear of clothed Europeans by 'throwing off [his] Trousers' before entering the Ka'bi campsite. ${ }^{14}$

Another form of cruelty, in Eliza's report, was the paucity of food. If, however, the Europeans were unable to support the group, even when consigned the most menial, unspecialised tasks, their demand for food, especially during exigencies of midwinter, would have seemed unworthy. Eliza's situation created a conundrum: she was too weak to perform the arduous tasks and only food and rest could have strengthened her. Imbued with the British sense of propriety, she would not have been able to appreciate what the Aborigines expected of her. Similarly, Indigenous misunderstanding, and ignorance of her past trials, meant that the Ka'bi were likely to have goaded her to perform more efficiently. For Eliza who (unlike the Ka'bi) reported her side of the story, being assigned the demeaning tasks of a servant, and the further societal insult of disrobing in compliance with the cultural group, were perceived as emotional cruelties, in addition to the physical ones. She reported that:

During the whole of my detention among the natives I was treated with the greatest cruelty being obliged to fetch wood and water for them and constantly beaten when incapable of carrying the heavy loads they put upon me; exposed during the night to inclemency of the weather being hardly ever allowed to enter their huts even during heaviest rain. ${ }^{15}$

Eliza, however, was expected to do no more nor less than any Aboriginal woman would do: dig roots, find food and firewood, and live a Spartan existence. ${ }^{16}$

Eliza's complaint that the staple food was a fern root, which she had to procure for herself, with only small portions of fish granted to her, opens several lines of analysis. In the first place, her middle-class European expectation of ample food supplies, readily available to curb her hunger, collides with the Aborigines' daily food-gathering methods. The small portion of fish allowed her also complies with Indigenous food intake, which depended on vegetables

14 'John Graham's Report', Dwyer and Buchanan, Rescue of Eliza Fraser, 1986: 31.

15 Dwyer and Buchanan, Rescue of Eliza Fraser, 1986: 36.

16 Sinclair 1990: 77. 
and fruits. John Mathew, who lived on his uncle's station in Ka'bi country for over six consecutive years up to 1872 , and who made returned visits in 1884 and 1906, knew the Ka' bi well and spoke their dialect. He wrote that, when the $\mathrm{Ka}$ 'bi ate meat, it was a 'rather irregular meal'. ${ }^{17}$

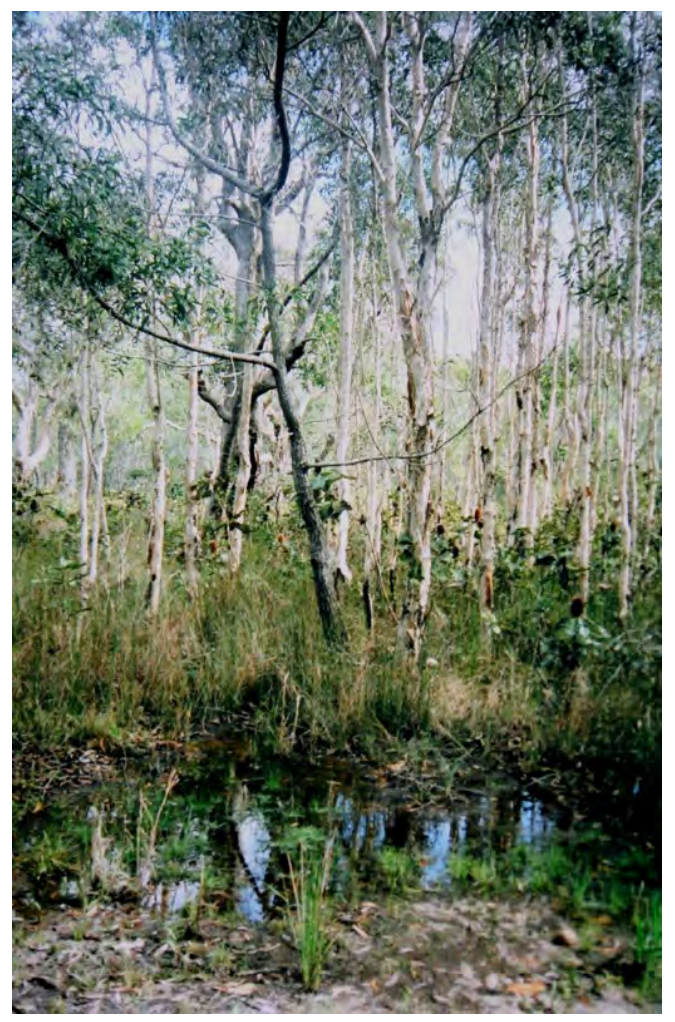

\section{Illustration 3. Marshy ground on the banks of the Noosa River near Fig Tree Point, where Eliza Fraser lived with the Ka'bi people.}

Source: Barbara Dawson, July 2005.

Furthermore, it is unclear whether the food supply for Eliza was the same for the European men. In colonial texts that refer to the social treatment of Aboriginal women, British writers often refer to the women having only occasional access to meat. Eliza's need for food and rest to recover from her debilitation after her various ordeals would have further compounded her plaintive account. Notwithstanding an attempt to analyse the reasons behind her report, the difficulty remains in explaining a text that may rely as much on the scribe as on Eliza's rendition for the terms and attitudes expressed. Nevertheless,

17 John Mathew, Two Representative Tribes of Queensland: With an Inquiry concerning the Origin of the Australian Race, T Fisher Unwin, London and Leipsic [sic], 1910: 85. 
the reference to the emotive word, 'cruelty', in Eliza's account has become the foundation stone for the Eliza Fraser 'industry' in which commentators around the world, including in Britain, North America and Australia, were to reconstruct and reinterpret Eliza's experiences within the context of the 'savage' treatment of a helpless white female.

Eliza's second complaint about lack of protection from the weather also needs to be taken into context. Firstly, Ka'bi dwellings were simple and small. Mathew stated that:

The ordinary style of house was a mere bark shelter. Three or four sheets of bark were set obliquely with the lower ends in a semicircle, on the ground, and the upper ends, overlapping, gathered together and supported by light saplings. This sufficed for a family ... each [dwelling] had its own small fire in front. ... Grass was strewn on the floor for a bed. If rain threatened, a rut was dug round the back of the humpy to serve as a drain. The warriors' spears were stuck in the ground, ready to hand, at the side of the rude shelter. ${ }^{18}$

Secondly, Eliza's position in the tribe was ambiguous. Who should take her in? Was she expected to fall back on her own devices and make her own shelter? As the Ka' bi considered white people to be 'ghosts from the world of Spirits', ${ }^{19}$ her physical needs may have been unrecognised. Did she in fact need shelter? If the Ka'bi did perceive her as a living, human form, they were unlikely to have seen settlers' dwellings, and therefore been unable to understand her needs. Perhaps, if she had complained, she might have been seen as ungrateful. She appears to have been left in an unresolved position, sometimes gaining shelter and sometimes, not.

Mathew described the Ka'bi as a lithe, fit people, with 'elastic tread and graceful bearing'. The men were fairly short (about $166 \mathrm{~cm}$ ) and, in proportion, the women 'rather tall'. The people were:

light in the bone. The lower part of the limbs was usually fine. The thighs, much more rarely the calves of the legs, were well developed. The muscles of the back and breast were often prominent. In walking, the head was thrown well back. ${ }^{20}$

18 Mathew 1910: 84.

19 'John Graham's Report', Dwyer and Buchanan, Rescue of Eliza Fraser, 1986: 30.

20 Mathew 1910: 73. 
An 'eight years' resident' of Queensland, writing in 1876, similarly stated that the Aborigines of the area were 'a fine race of men ... finely-formed and well-developed [with] a dignity of gesture, a firmness of tread, a litheness and gracefulness of motion'. He noted that their 'strength is very considerable'. ${ }^{21}$

Compared with these strong, energetic people, with a physique suited to walking, Eliza, already weakened, would have proved a liability to the Ka' bi as they moved through their marshy country, gathering wood and searching for the plants on which they subsisted.

\section{Death of James Fraser and Charles Brown}

Eliza also offered details of the deaths of her husband and of Charles Brown, both of whom were unable to keep up with the needs of the group, and who were to die during their time amongst the Ka'bi. In her initial account, she states that:

In consequence of [the] hardships [of lack of food and heavy work] my husband soon became so much weakened as to be totally incapable of doing the work that was required of him, and being on one occasion unable through debility to carry a large log of wood one of the natives threw a spear at him which entered his shoulder a little below the bladebone. Of this event he never recovered and being soon after seized with a spitting of blood he gradually pined away until his death which took place eight or nine days afterwards ... When he died they dragged him away by the legs and buried him. ${ }^{22}$

A version of Brown's death, which Eliza initially stated she did not witness, appeared in a second, sensational account, published in the Sydney Gazette on 18 October 1836. This report, presented to the public after Eliza's arrival in Sydney, relied on melodramatic 'quoted' dialogue and emotive language to lure the eye of the reader. In describing Brown's death, it introduced the popular trope of cannibalism, which had been developed by Daniel Defoe in Robinson Crusoe (1719). The newspaper account reads:

In eight days from this brutal affair [Captain Fraser's death] the same cannibals also killed Mr Brown, the chief officer, by holding firebrands

21 The Queen of the Colonies; or, Queensland As I Know It. By An Eight Years' Resident, Sampson Low, Marston, Searle, \& Rivington, London, 1876: 308, 309.

22 'Mrs Fraser's Narrative', Dwyer and Buchanan, Rescue of Eliza Fraser, 1986: 36. 
to his legs, and so burning him upwards! The cause of their destroying Mr B., was in consequence of his showing some signs of dissatisfaction in the death of his Captain. ${ }^{23}$

In later reconstructions, the descriptive 'cannibal' becomes synonymous with 'Aborigine'. This version had already introduced a motive for the killing.

The report in Bell's Weekly Messenger by Lieutenant Otter (who had led the rescue party) gives another interpretation. He states impassively that the sores on Brown's legs caused him to lie in a helpless state on the ground, and he therefore 'starved to death'. ${ }^{24}$

Recent research into the increasingly distorted representations of the 'Eliza Fraser Saga' has offered explanations of the Aborigines' actions. Elaine Brown, in Cooloola Coast, points out that Eliza not only indicated that the Ka'bi acted kindly towards Brown in the days before he died, but also offered extra fish to Fraser on the eve of his death - an action which Eliza regarded as treachery. Brown also suggests that the application of heat to ulcers on Charles Brown's legs and back was to treat his condition, and not to harm or torment him. ${ }^{25}$

Instead of the exaggerated reconstructions that depicted the deaths of these men to incorporate torture, torment and murder, Mathew presents a contrary picture of the Ka'bi. He contended that, 'On the whole, I would say they were a goodnatured, kind and gentle people'. Robert Darge, one of the men who chose to walk to Moreton Bay but who later stayed with Aborigines, also reported that: 'I cannot call them a cruel people'. Nor did Hobhouse, Wheeler and Ginsberg find any evidence of brutal tendencies in their study for London University's School of Economics and Political Science. Based on secondary sources, their statistical appraisal indicated that quarrels amongst the Ka'bi were settled 'by a duel of endurance'. The authors did not 'hear of homicide, and enter them only upon the more doubtful list'. John Graham also reported the Ka'bi's timidity, and fear of the white man. ${ }^{26}$

\footnotetext{
23 Sydney Gazette, 18 October 1836: 3. This account was reproduced in The Edinburgh Evening Courant, 27 March 1837: 4.

24 Bell's Weekly Messenger, 17 September 1837: 3.

25 Brown 2000: 109. Another valuable source is Brown 1994: 345-360. Numerous other twentieth-century commentators have endeavoured to unravel the inconsistencies, misconceptions and historical errors; cf. Drummond 1993: 15-25.

26 Mathew 1910: 24; Alexander 1981: 136; Hobhouse, Wheeler and Ginsberg 1915: 136. The latter study depended on anthropological reports from 'travellers, missionaries, explorers, and casual observers' and from ethnographers, Hobhouse, Wheeler and Ginsberg 1915: 7, 8; 'John Graham's Report', Dwyer and Buchanan, Rescue of Eliza Fraser, 1986: 29-32.
} 
In the light of these testimonials, a new interpretation of the behaviour of the Indigenous women, when they first met Eliza, can be mooted. Eliza's second account of her experiences, published in the Sydney Gazette, October 1836, states that:

Captain Fraser suggested giving themselves up quietly to the natives, as they were entirely defenceless, and, of course, already in their power. They had scarcely time to make the suggestions when several tribes came down upon them, one of whom immediately captured Captain Fraser, another tribe took Mr Brown, and a third Mr Baxter. The natives would not allow Mrs F. to go with either [sic] of them, and left her alone upon a sandy beach the whole of the day; and the next morning a number of old women came down to the beach, with some children - they gave Mrs Fraser to understand, that she must go with them and carry one of the children upon her shoulders, which Mrs Fraser of necessity complied with. Mrs Fraser states that she travelled many miles into the bush with these women and the child, and was frequently exhausted upon the road..$^{27}$

Knowledge of Indigenous culture can now explain Eliza's treatment at the hands of the Ka'bi women. Forced to remain behind on the beach when the men were led away by Aboriginal men, she had to wait until the women came to accept her next day. She had also been prevented from any contact with either her husband or Brown for at least three weeks, up to the time of Fraser's death. Elaine Brown's research into Ka'bi cultural practices has led her to believe that, during menstruation and after childbirth, Indigenous women remained separated from the men. ${ }^{28}$ When taken in by the Aborigines on about 26 June, only about one month had elapsed since Eliza had given birth. The stripping of Eliza's clothes would have revealed her physical state. By the time Graham reached her on 17 August, however, Eliza had joined the whole group, indicating that, about 11 weeks after childbirth, she was again socially acceptable in mixed company.

This second report also refers to the task of caring for an Aboriginal infant, which, in Eliza's post-partum state, most probably involved breast-feeding, a detail not mentioned either by Eliza nor by the male authors of the nineteenthcentury reconstructed narratives. The Ka'bi, however, sending not only their women, but also a child to Eliza, appeared to be aware of her potential usefulness to the group. Eliza's further complaints of having salt sand thrown over her, and

27 Sydney Gazette, 18 October 1836: 3. The editor in 1836 was ticket-of-leave convict, William Watt who, in February 1836, had married Ann Howe, proprietor and widow of former owner, Robert Howe, Sandy Blair, 'Howe, Ann (c. 1802-1842)', ADB, NCB, ANU, http://adb.anu.edu.au/biography/howe-ann-12994/text23487, accessed 3 November 2013.

28 Based on Indigenous taboos relating to women and blood, Brown 2000: 107. Mary Douglas also refers to this form of pollution within Indigenous societies, Douglas 1975. 
of having her body rubbed with charcoal, grease, resin and leaves are processes now known to be forms of cleansing, and of the Aborigines' means of protecting themselves from the elements. ${ }^{29}$

\section{Reconstructing the story}

The marketability of such a sensational story plunged Eliza into early deception as she sought to exaggerate her tale for financial gain. In Sydney she had already received $£ 400$ from a sympathetic and curious public, concerned about her welfare. On 3 February 1837, she married another ship captain Alexander John Greene and, after her return to Britain on his ship Mediterranean Packet, she and her husband capitalised on the publicity surrounding Eliza as a survivor of an extraordinary experience.

Falsely pleading a demoralised state of widowhood, destitution and cruel abuse, Eliza was assisted by the Lord Mayor of London, who organised a subscription campaign that resulted in the donation of $£ 50$ for Eliza, and $£ 482$ for her surviving children. Greene has been suspected as the instigator of further commercial manipulation by possibly parading Eliza as an attraction, along with an embellished story, for $6 \mathrm{~d}$ a look in London streets. ${ }^{30}$ The sensational message promoted and extended in each re-telling was of the cruelty of the barbaric savages and the 'miraculous' salvation of the civilised white woman.

Further distorted accounts quickly followed, feeding the folklore of 'savage' and 'cruel' Aborigines. By 1840, a plethora of pamphlets, chapbooks, broadsheets and monographs had been published on the theme of Eliza Fraser. In the first children's book to be published in Australia, A Mother's Offering to her Children (1841), the author Charlotte Barton includes the story of Eliza Fraser's plight, in which Aboriginal 'monsters' capture her and treat her with 'wanton barbarities'.31

One pamphlet, designed for the North American market, was Narrative of the Capture, Sufferings, and Miraculous Escape of Mrs Eliza Fraser, published in

\footnotetext{
29 Sydney Gazette, 1 February 1838: 2; also recorded in Dwyer and Buchanan, Rescue of Eliza Fraser, 1986: 43-44; Brown 2000: 107.

30 In about 1837, Henry Russell saw a woman in a London street, purporting to be Eliza, Henry Stuart Russell, The Genesis of Queensland, Vintage Books, Toowoomba, 1989 [1888]: 250. It may, however, have been one of the many 'Eliza' impostors who capitalised on her story.

31 A Mother's Offering to Her Children by A Lady Long Resident in New South Wales, Facsimile edition, The Jacaranda Press, Milton, Queensland, 1979 [1841]: 170-183; Patricia Clarke, 'Barton, Charlotte (1796-1867)', $A D B, \mathrm{NCB}, \mathrm{ANU}, \mathrm{http} / / / \mathrm{adb} . \mathrm{anu} . e d u . a u /$ biography/barton-charlotte-12787/text23073, accessed 2 February 2013. Charlotte was the mother of the writer Louisa Atkinson.
} 
New York, in $1837 .{ }^{32}$ This version included an account, typically in the first person and reputedly submitted by Eliza in Liverpool, England, on 2 July 1837. According to Kay Schaffer, who has extensively analysed and assessed the various versions of Eliza's story, ${ }^{33}$ this North American text joins the classic American captivity genre in which the myth involved European colonists versus the Indians. ${ }^{34}$

In a society strongly influenced by Christian evangelism, these discourses were presented as Puritan tales of religious deliverance, replete with the literary devices of melodrama, and the narrative elements of the sentimental novel and the psychological thriller. They followed early Puritan narratives in which the wilderness, inhabited by savage natives, was typically portrayed as the domain of sin, which tested the faith of its God-fearing victims. The recurrent miraculous escape becomes analogous with redemptive salvation. Intrinsic to the tales was the secular propaganda tract of good, white hero versus the treacherous, black native.

The 1837 pamphlet is full of North American terms and illustrations. Aborigines wear full togas or skirts, ankle-high moccasins and feathered headdresses. Their weapons are bows and arrows or the tomahawks of American Indians. They live in conical wigwams, surrounded by northern hemisphere trees. Indigenous women are called 'squaws' and their society has a chief - a societal structure characteristic of American Indians, but not known as a usual part of Australian Aboriginal culture. The idea of miscegenation is introduced, providing a touch of intrigue and titillation, as James Fenimore Cooper's The Last of the Mohicans (1826) had done. An honour duel adds heroic tension to the plot.

Furthermore, the text implies a forced capture and imprisonment. This argues directly against Eliza's statement in the Sydney Gazette in October 1836 that, when the Aborigines first approached the survivors on the beach, Captain Fraser 'suggested giving themselves up quietly to the natives, as they were entirely defenceless'. The fictitious nature of this version can be seen in the contradiction within the pamphlet, where Eliza 'stated' that, 'my husband suggested the propriety of our quietly surrendering ourselves prisoners to them, as we possessed not a single weapon with which to defend ourselves' ${ }^{35}$

Throughout the American text, Eliza is attributed with the faith that God would rescue her from brutal captivity. She makes daily prayerful supplication for

32 Narrative of the Capture, Sufferings, and Miraculous Escape of Mrs Eliza Fraser, Charles S Webb, New York, 1837.

33 Includes Schaffer 1995; Schaffer 1989: 1-15; Schaffer 1991: 114-119; Schaffer 1993; Schaffer 1994: 117-

140; Schaffer 1998: 79-96.

34 Schaffer 1993: 6-7; Slotkin 1973: 6-7, 26

35 Dwyer and Buchanan, Rescue of Eliza Fraser, 1986: 41; Narrative of the Capture, 1837: 7. 
deliverance and serves as a testimony to God's miraculous intervention on behalf of the pious. ${ }^{36}$ This version of events extended the derogation of Australian Aborigines to North American readers.

\section{John Curtis' version}

The next year, in 1838, the London newspaperman and court reporter John Curtis wrote the official English account of Eliza Fraser's 'ordeal', Shipwreck of the Stirling Castle containing A Faithful Narrative of the Dreadful Sufferings of the Crew, and the Cruel Murder of Captain Fraser by the Savages. Also, The Horrible Barbarity of the Cannibals Inflicted upon The Captain's Widow, Whose Unparalleled Sufferings are Stated by Herself, and Corroborated by the Other Survivors. Curtis had been commissioned to write the account as a defence and apology for Eliza, and as a justification of her cause, after her deception resulted in considerable charitable contributions being made to her. Its political aim was to save from embarrassment the Lord Mayor of London, who had opened the subscription campaign. Although Curtis attended the inquiry which investigated Eliza's claims of destitution, and from which he gained first-hand information from Eliza, Baxter and Darge, his written version of events was dependent on the message he aimed to transmit. Out of Eliza's reports, and Baxter and Darge's testimonials, this armchair theorist created a 270-page narrative.

In his representation of Aborigines, Curtis relied heavily on the established literature that depicted their primitive behaviour and 'fiendish cruelty'. Another layer to his work, however, was to convey a moral lesson to civilised Englishmen and, further, to encourage missionary work among the pagan Aborigines. His book was published one year after the founding of the British and Foreign Aboriginal Protection Society, and coincided with the establishment of the Aboriginal Protection Society in Sydney. Within the same volume is found the Narrative of the Melancholy Wreck of the Charles Eaton, the publication of which had been made possible by the 'kindness of the highly-respected Secretary of the London Missionary Society'. His stated confident aim was 'to render the history subservient to the cause of morality, and we trust that we have performed our promise. ${ }^{37}$

Curtis used Biblical quotations to gear his evangelical message. Quoting incongruent references from the Old Testament, Curtis extrapolated that Aboriginal men are 'blood-thirsty and wicked ... whose tender mercies are

36 Narrative of the Capture, 1837: 22, 19.

37 Curtis 1838: 375-376, i-ii; Schaffer 1993: 9-10; Schaffer 1995: 74. 
In the Eye of the Beholder

cruelty, and whose habitations are polluted with blood' ${ }^{38}$ He wrote that they are 'demons in human form [who] employed every method which they could devise, to torture and annoy their miserable captives'. Indigenous women were 'heartless brutes' with 'fierce, shrill yells'. He quoted Eliza as asserting that Aborigines 'all delight in cruelty' ${ }^{39}$ His religious tone in the text is emphasised by exhortations and supplications to God from the suffering protagonists.

Curtis's contribution to the Eliza Fraser saga was his production of an exaggerated sham. Once again, and not for the last time, Indigenous Australians were the victims of a very bad press.

38 Curtis 1838: 82-83; Proverbs XII, 10: 'A righteous man regardeth the life of his beast: but the tender mercies of the wicked are cruel'; Lamentations IV, 14: 'They have wandered as blind men in the streets, they have polluted themselves with blood, so that men could not touch their garments', Old Testament, King James version.

39 Curtis 1838: 78, 143, 156. 


\section{Literary Excesses-Eliza Davies: Imagination and Fabrication}

'Oh what a tangled web we weave, When first we practise to deceive!'

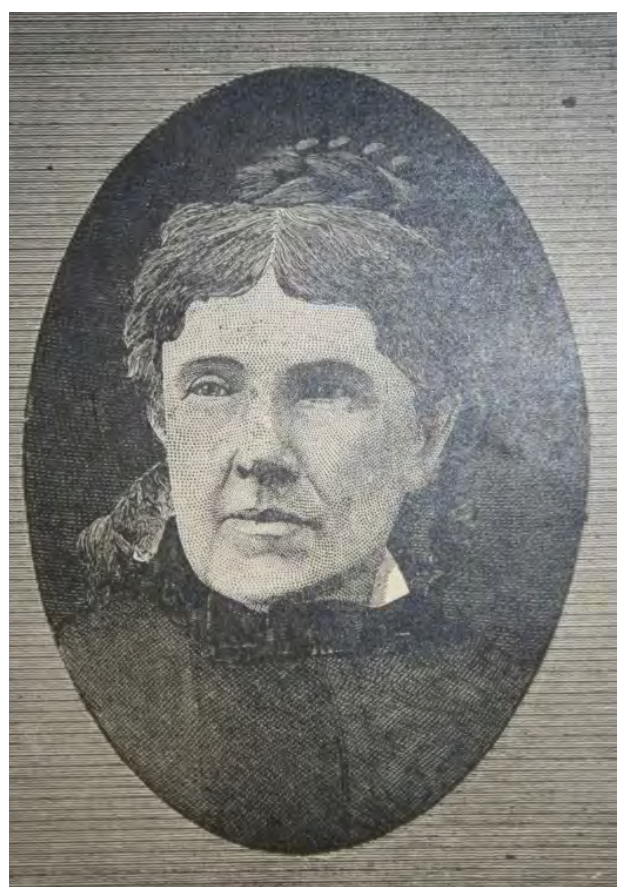

Illustration 4. Eliza Davies.

Source: Frontispiece, Mrs Eliza Davies, The Story of an Earnest Life: A Woman's Adventures in Australia and in Two Voyages Around the World, Central Book Concern, Cincinnati, 1881.

1 Sir Walter Scott, Marmion, Canto VI, 17. 


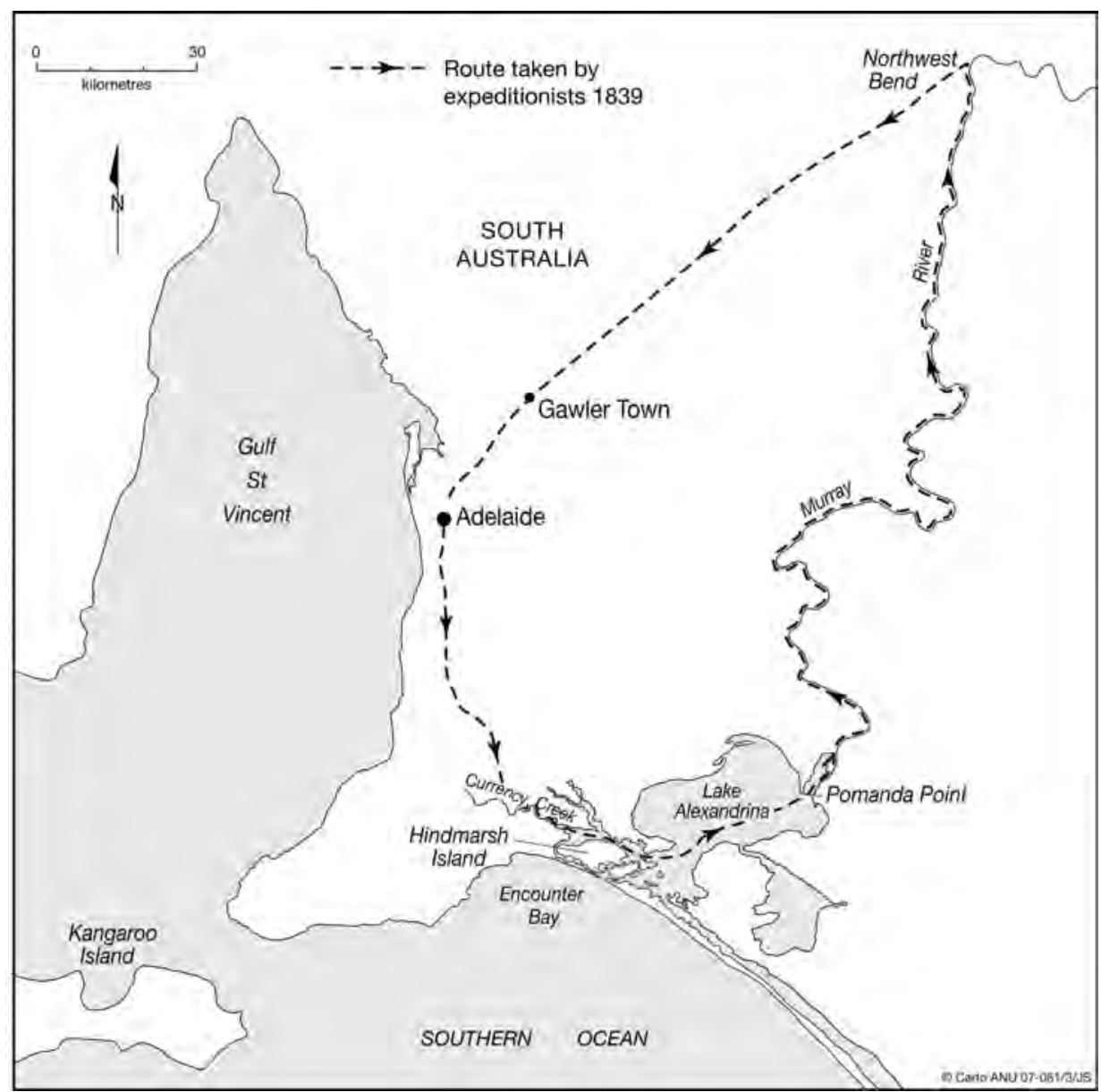

Map 3. Eliza Davies. South central South Australia in the vicinity of Gulf St Vincent and the lower course of the Murray River showing the route of the Sturt expedition in 1839.

Source: CartoGIS, College of Asia and the Pacific, ANU.

Eliza Davies (formerly Arbuckle) was well educated, well read and well travelled. All these factors influenced the way she wrote about Indigenous Australians in her 570-page autobiography, The Story of an Earnest Life: A Woman's Adventures in Australia and in Two Voyages Around the World. ${ }^{2}$ Eliza met Aborigines briefly when, in 1839, aged 18 years, she joined the explorer Charles Sturt and the South Australian governor, George Gawler, for a five weeks' tour of the lower reaches of the Murray River. At the time, she was employed by Sturt as a servant, or second nursemaid. Keen to promote inland settlement by allaying fears that

2 Mrs Eliza Davies, The Story of an Earnest Life: A Woman's Adventures in Australia and in Two Voyages Around the World, Central Book Concern, Cincinnati, 1881. 
travel into the interior was unsafe for women, Sturt included his wife, Charlotte, in the group, and Gawler, his 15-year-old daughter Julia - whose participation is thought to have been the reason for the inclusion of the similarly-aged 'servant maid', Eliza Arbuckle. ${ }^{3}$

Forty years after this adventure and by then living in the United States of America, Davies incorporated her long ago experience in a faraway country into her extensive life story. By the end of her life, she had established and taught in schools in two Australian colonies and in America. She had circumnavigated the globe twice - a feat she proudly proclaimed in the title of her book-lived in New South Wales on four different occasions, in South Australia three times and the United States, twice, where she published her book, and where in Lexington on 27 March 1888, she died. Her version of Australian Aborigines was written for North American readers, having absorbed over the years the racial views and interpretations of others. In presenting her tale she experimented with a variety of styles and narrative forms, involving dramatic shifts in narrative focus.

\section{'A wild man is a miserable animal'}

A voracious reader, Eliza had read in those intervening years the current scientific works on racial theory that were to influence her depiction of Aborigines. Among these were Charles Darwin's Journal of Researches into the Natural History and Geology of the Countries Visited During the Voyage of H.M.S. "Beagle" Round the World, first published in 1839, and Josiah Nott and George Gliddon, Types of Mankind: or, Ethnological Researches, Based Upon the Ancient Monuments, Paintings, Sculptures, and Crania of Races (1857).

In his diary, kept while on board the Beagle from 1831 to 1836, Darwin had recorded that 'A wild man is a miserable animal'. He described the people of Tierra del Fuego as 'untamed' savages, who were 'wretched looking beings' with no proper clothing, no fit language and no decent homes, writing that:

I would not have believed how entire the difference between savage \& civilized man is. - It is greater than between a wild \& domesticated animal ... I believe if the world was searched, no lower grade of man could be found. ${ }^{4}$

\footnotetext{
3 Davies underlined this idea with her statement that: 'Capitalists would not fear the savages when ladies had traversed the country in safety', Davies, The Story of an Earnest Life, 1881: 121.

4 Richard Darwin Keynes (ed.), Charles Darwin's Beagle Diary, Cambridge University Press, Cambridge, 1988: 122, 125. Also cf. Desmond and Moore 1991: 132-133.
} 
During a visit to Sydney in January 1836, Darwin met some Aborigines in the Blue Mountains on his way to Bathurst. In about 1867, Davies visited the Blue Mountains, having been inspired by Darwin's description of the 'Weatherboard Falls'. Darwin wrote of the Aborigines that:

They were all partly clothed, and several could speak a little English: their countenances were good-humoured and pleasant, and they appeared far from being such utterly degraded beings as they have usually been represented. In their own arts they are admirable. A cap being fixed at thirty yards distance, they transfixed it with a spear, delivered by a throwing-stick with the rapidity of an arrow from the bow of a practised archer. In tracking animals or men they show most wonderful sagacity; and I heard of several of their remarks which manifested considerable acuteness.

This was faint praise, for Darwin concluded that, 'On the whole they appear to me to stand some few degrees higher in the scale of civilization than the Fuegians'.5

Nott and Gliddon's Types of Mankind (which Davies had read after her return to the United States in 1874) promoted the idea that anatomy and physiognomy were important factors in assessing different racial groups. These elements entered Davies' descriptions of Aborigines. One paper by Dr Samuel Morton was entitled 'On the Size of the Brain in Various Races and Families of Man'. Another, 'On the Origin of the Human Species', assessed the influence of 'climate, locality, civilization, and other physical and moral agents, acting through long periods of time'. Diagrams and sketches of a Roman head of Apollo, a 'Negro' and a 'Young Chimpanzee', placed adjacent to each other, graphically compared skull shapes, particularly of jaw and forehead. The inclusion of the chimpanzee skull plunged the comparison into the realm of hierarchical evolutionary theory. ${ }^{6}$ Hints of the influence of these works appear in Davies' narrative.

Davies also replicated in her text the racial clichés of Joseph Banks. Like Banks, she extended the connection between Aborigines and beasts when she depicted Ngarrindjeri and Meru people as animal-like people with the physical skills

5 Charles Darwin, Journal of Researches into the Natural History and Geology of the Countries Visited During the Voyage of H.M.S. "Beagle" Round the World, Sixth Edition, Ward, Lock and Co., London, New York, and Melbourne, 1889: 315.

6 Davies, Story of an Earnest Life, 1881: 317; Josiah Nott and George Gliddon, Types of Mankind: or, Ethnological Researches, Based Upon the Ancient Monuments, Paintings, Sculptures, and Crania of Races, 8th edition, J B Lippincott, Philadelphia, 1857: 298, 305, 458. 
of agility and speed in running. Edward Long's descriptions of Negroes, the Hottentots of southern Africa and orang-outangs (the newly discovered 'wild man' or 'missing link') had added to current perceptions. ${ }^{7}$

The ideas of Australian commentators also entered her prose. In The Aborigines of Australia, Roderick Flanagan depicts Aborigines as 'degenerate', cannibalistic and low in the human scale of existence, without a system of government or religion understandable by nineteenth-century British codes. Flanagan includes a description of an Indigenous 'future wife' being 'carried off by her admirer by main force', ${ }^{8}$ an episode that Davies also incorporated in her story.

Two nineteenth-century crazes may have skewed Davies' interpretation of Indigenous people. The first was the popular 'science' of phrenology, founded by the German, F J Gall, and introduced to English-speaking readers by George Combe in Elements of Phrenology (1824) and The Constitution of Men (1828). Phrenology, as seen in Nott and Gliddon's Types of Mankind, relied on the theory that specific parts of the brain were responsible for particular moral and intellectual characteristics; and the shape of a person's skull was assumed to be associated with certain racial attributes. It was often invoked to cast Aborigines into an inferior social and racial position. Australian commentator J O Balfour had decreed that Aborigines' heads were 'all much larger behind than in front [and] are certainly not such as a phrenologist would admire'. He loathed their 'low ... almost ... the no forehead ... the shaggy eyebrows protruding over and almost hiding the small keen eyes - the flabby nose ... the thick lips and the snow-like teeth, common to cannibals'. Even Godfrey Mundy, more sympathetic towards Aborigines than Balfour, felt that the 'Australian cranium is exceedingly ill-shaped - the animal bumps largely preponderating over the intellectual'. ${ }^{9}$

The travelling circuses of American showman and entrepreneur Phineas Taylor Barnum were also hugely popular in the nineteenth century. As proprietor of the American Museum of Natural History in New York from 1841, P T Barnum

7 Cf. Edward Long, The History of Jamaica, Or, General Survey of the Antient and Modern State of that Island: with Reflections on its Situation, Settlements, Inhabitants, Climate, Products, Laws, and Government, Volume 3, T Lowndes, London, 1774: 351-355, 363-365; Walvin 1973: 163, 168-170.

8 Roderick Flanagan, The Aborigines of Australia, first published as a series of articles in 1853-54 in the Sydney Empire, Edward F Flanagan and George Robertson and Company, 1888: 17-18. This, however, may have been a well-known trope: Godfrey Mundy in 1852 had similarly written that Indigenous women were '[w]ooed, as it is said, by dint of blows', Lt. Colonel Godfrey Charles Mundy, Our Antipodes: Or, Residence and Rambles in The Australian Colonies. With A Glimpse Of The Gold Fields, In Three Volumes, Second Edition, Revised, Richard Bentley, London, 1852, Vol. I: 219. In contrast to these views, Peter Cunningham (naval surgeon on convict transports and short-term settler) referred to Aborigines as 'lively, good-humoured, inquisitive, and intelligent', quick to learn to read and write and to speak English, P Cunningham, Surgeon, RN, Two Years in New South Wales; A Series of Letters, Comprising Sketches of the Actual State of Society in that Colony; Of Its Peculiar Advantages to Emigrants; Of Its Topography, Natural History, \&c. \&c., In Two Volumes, Henry Colburn, London, 1827, Vol. II: 45, 21.

9 Reynolds 1996 [1987]: 113-115; J O Balfour, A Sketch of New South Wales, Smith, Elder and Co., London, 1845: 7-8; Mundy 1852, Vol. I: 219. 
presented to the public 'living curiosities', including a 'mermaid'. Capitalising on the current curiosity about native peoples, he also exhibited 'freaks of nature' from around the world. Within this display mentality, Indigenous people were viewed, like the eighteenth-century Negro, as fascinating (so-called) 'missing links'. The height of Barnum's success coincided with the time that Davies was living in the United States. ${ }^{10}$

\section{'A sad and lonely ... childhood'}

With a large reading repertoire, Davies was particularly devoted to nineteenthcentury melodramatic romantic literature. This was characterised by pathetic accidents or occurrences, reliance on cliché, and shallow and exaggerated emotion from which the author extorted more feeling than a situation warranted. Popular themes were unrequited love, true love involving a disharmony of race or class, conflict between ideals and circumstances, and forced captivity and providential escape from the clutches of unsuitable suitors, evil doers (or savage heathens). Sympathetically drawn women were often the heroines. Charlotte Bronte's Jane Eyre (1847), which included enforced captivity, and Emily Bronte's Wuthering Heights $(1847)^{11}$ are well-known examples.

Even from the first pages of Eliza's story, melodrama intrudes. Depicting herself as a somewhat lost soul (although not later, after she found the Lord), she was born Eliza Arbuckle at Paisley, a town 11 kilometres west of Glasgow, Scotland, and baptised on 11 February 1821 in the parish of Renfrew. After her father's death and her mother's precipitate remarriage, Eliza was sent to school at an early age. Feeling unloved and rejected by her mother, she described her childhood as 'sad and lonely'. Her happiest days were spent on visits to the home of her nanny, Maggie Campbell, in the mountains of the Western Highlands. The sights and sounds of the Scottish Highlands and the myths and legends told to her by Maggie enriched her interest in Scottish history, and English and Scottish literature. After her nanny's death, feeling 'as much alone in my thoughts as was Robinson Crusoe on his island', she turned to reading for comfort. Soon 'charmed' by romantic novels, particularly those of Sir Walter Scott, she wrote that 'every one of Scott's heroines I admired and tried to imitate'. ${ }^{12}$

In her autobiography, Davies adopted the literary style of the romantic novels that she so admired. Charles Dickens' Oliver Twist (1838), Nicholas Nickleby (1839) and The Old Curiosity Shop (1841) are examples of early nineteenth-century novels that contain sentimentality or excessive emotionalism, with a heightened

10 Cf. Ritvo 1997; Goodall 2002: 21; Poignant 2004: 148-153.

11 Stringer 1996: 578.

12 Davies, Story of an Earnest Life, 1881: 50, 27. 
sensibility to human suffering. In order to find a market, writers conformed to the rigid, moral expectation of public taste, ruled by evangelicalism. To instruct, while offering 'wholesome' and religiously pure topics, therefore remained strict literary requirements.

\section{Christian Evangelism}

The other great influence in Eliza Davies' life was her religion. It underlay all parts of her narrative and geared her life's choices and direction. During her unhappy childhood she had turned for comfort 'from [her] earthly to [her] heavenly parent'. ${ }^{13}$ A member of the Scottish Baptist Church in Paisley, Eliza decided to emigrate with a family from her church. She wished to escape her mother, who planned to marry her to a much older man. Aged 17, she left Greenock for New South Wales on 24 August 1838. The strength of her Christian commitment from this early age is seen in her elected choice of 'religion'. Out of the 253 mainly Protestant passengers on board the barque, Portland, which sailed into Port Jackson in December 1838, Eliza was the only person who chose 'Dissenter' ${ }^{14}$ as her religion.

After the exploratory expedition in South Australia, Charlotte Sturt had determined, against Eliza's will, that in 1840 she marry William Davies, ${ }^{15}$ a man who turned out to be violent and abusive. Eliza left him in 1842 and returned to Sydney. In 1847 she went back to Scotland with the family that employed her, expecting to stay for two years. It was there, however, that her vocation as a devout member of the Church of Christ was established and her life's direction forever changed.

From the pulpit of her Baptist church in Paisley in August 1847, Davies heard the missionary message of the Reverend Alexander Campbell, who was visiting from the United States. A former Scot, in 1826 Campbell had preached his new Bible-based doctrine to the congregation of the Cincinnati Sycamore Street Baptist Church. In response, nearly the entire new and flourishing congregation

\footnotetext{
13 Davies, Story of an Earnest Life, 1881: 67.

14 Dissenters, who included Wesleyan Methodists, some Presbyterians, the Independents, Congregationalists, Baptists and Quakers were nonconforming Christians who sought their own direct relationship with God, outside and at variance with the established tenets of the accepted state religion of the Church of England. They were particularly strict in their practices and in their moralising attitudes, Gunson 1978: ix; Young 1953: 4, 8; Bolt 1971: 209; Sydney Herald, 24 December 1838: 2-3; Index to Passengers to Sydney 1838-1842, Habart Samuel - Justus John, Archives Authority of New South Wales, AO Reel 4; Immigration Agents' Immigration Lists, April 1838-November 1841: Assisted Immigration, NLA mfm N229, Archives Authority of NSW, Reel No. 2134.

15 Copy of certificate of marriage to William Davies on 17 April 1840, in Ward 1994: 43.
} 
joined with Campbell to form the 'Disciple' society (later the Church of Christ). ${ }^{16}$ In 1847, Davies was similarly moved. Although planning to remain in Scotland for two years, inspired and encouraged by Campbell she sailed for America after only three months, arriving in the United States in November 1847.

Living first with the Campbell family in Bethany, West Virginia, Davies then worked until 1853 as associate principal and assistant matron at the Kentucky Female Orphan School in Midway. She afterwards privately taught the children of the Kentucky evangelist, John Gano. In 1857, at the request of her half-sister, who lived in Sydney, she sailed again for New South Wales. Her proselytising mission, strengthened and focused during ten years in the United States, now went hand-in-hand with her vocation as a teacher.

Although originally hoping to open an orphans' school along similar lines to the Female Orphan School in Kentucky, Davies travelled 120 kilometres south of Sydney to Kiama where, in 1858, she established a school at Mount Pleasant for the children of workers on the pastoral property, 'Omega Retreat'. Davies coined this school 'Hurricane Hill', because of the winds, rains and storms that beset the wooden slab schoolhouse in $1860 .{ }^{17}$ Her main mission in Kiama had been to introduce to the residents of Kiama the American revised version of the Bible's New Testament.

In 1861, Davies sailed for South Australia, apparently seeking out Christian companionship in Adelaide, where a Church of Christ community had developed around New Zealand immigrant, Thomas Magarey. ${ }^{18}$ Alarmed to hear that her husband was still alive (although having bigamously remarried), she successfully filed for divorce, then fled back to what she described as 'the crimestained' colony of New South Wales. Although craving the camaraderie of her American Christian friends, Davies' return to Kentucky had been prevented by the commencement of hostilities in the American Civil War of 1861 to 1865.

Davies again turned to teaching, establishing the Bethany School in the undeveloped bush of North Sydney. The site is now Willoughby Public School. ${ }^{19}$ In 1862 North Sydney was a 'destitute and wicked' place, where the 'people are so wicked, and the young people perishing for instruction, and plenty of wild children there'. Davies described the adults as 'low, ignorant,

16 Henry A Ford and Mrs Kate B Ford, History of Cincinnati, Ohio, With Illustrations and Biographical Sketches, L A Williams \& Co., Cleveland, Ohio, 1881: 167.

17 The Illawarra Mercury, 3 August 1860: 2, 3, reported that the region had suffered wild storms, heavy rain and floods for the past six months.

18 Cf. Stephenson 1940: 19-20; Taylor 1946: 12-16.

19 Although Barbara Ward suggested that the Naremburn Public School was the site of Davies's Bethany School, her later research identified Willoughby Public School as the correct location, Ward 1994: 118, note 1, citing Naremburn Public School 1887-1987, Management Development Publishers Pty Ltd for The Centenary Committee of the Naremburn Parents and Citizens Association, Sydney, 1987: 14; Personal communication with B Ward, May 2006. A plaque in the pavement in Oakville Rd, Willoughby, acknowledges Davies' work. 
vicious and drunken, living by stealing. They were liars and swearers; the fear of God was not before their eyes, nor did they regard the laws of man'. Davies taught the children of this rough, criminal class of 'reprobates' from June 1862 to December 1869, introducing to them 'hymn singing, Bible reading and prayer meetings'. Bethany National School became a public school on 1 January 1867 after the passing of the Public Schools Act, 1866 (NSW), when William Wilkins was secretary of the Board of National Education and Henry Parkes was president of the New South Wales Council of Education. ${ }^{20}$

Sailing once more for Adelaide, Davies' final teaching position was at the Bowden Public School in the suburb of Hindmarsh, where she taught poor children of all denominations. ${ }^{21}$ The philanthropist, George Fife Angas, who is said to have contributed $£ 10,000$ a year to religious and educational causes during his last years, ${ }^{22}$ converted a granary into a schoolhouse and provided a house for her use on the site of a former flour mill, owned by Thomas Magarey, who also provided financial support. In December 1872, the South Australian Advertiser reported that the 'behaviour of the scholars, and their attainments in general knowledge reflected great credit upon Mrs Davies, the Superintendent of the school' ${ }^{23}$ Davies then returned briefly to New South Wales before sailing for the United States on 9 May 1874.

Story of an Earnest Life was published in Cincinnati, a city that was a centre for the Churches of Christ. In 1881 it boasted 210 churches of various denominations for a population of $255,000 .{ }^{24}$ Davies' story fitted the evangelical genre that flourished at the time. Among the Central Book Concern's other evangelical works were Joseph Martin's The Voice of the Seven Thunders: Or Lectures on the Apocalypse (1870) and T S Arthur's fictional evangelical book, Woman to the Rescue: A Story of the New Crusade (1874).

\section{The Ngarrindjeri and Meru}

The day that Davies arrived at Sydney on board the Portland on 18 December 1838 was significant in Australian history. Seven white men-Davies nominates the number as eight - were hanged for their part in killing 28 Aboriginal men, women and children in the Myall Creek massacre. By decrying the murders,

\footnotetext{
20 Davies, Story of an Earnest Life, 1881: 435, 436, 440; Fletcher and Burnswoods 1988: 9, 218-219.

21 This appears, nevertheless, to be a Church of Christ school, Stephenson 1946: 105; also Taylor n.d.: 107.

22 George Fife Angas left an estate of $£ 443,000$, 'Angas, George Fife (1789-1879)', ADB, NCB, ANU, http:// adb.anu.edu.au/biography/angas-george-fife-1707/text1855; Sally O'Neill, 'Angas, John Howard (1823-1904)', $A D B$, NCB, ANU, http://adb.anu.edu.au/biography/angas-john-howard-2890/text4141, both accessed 14 February 2013.

23 South Australian Advertiser, 16 December 1872: 3.

24 Ford and Ford 1881: 146.
} 
Davies appears to sympathise with the Aborigines, unlike many New South Wales pastoralists, who penned their angry reactions over several months in the pages of the Sydney Herald. Davies' first-hand account reads:

A famous day in the annals of crime was this day, in which we anchored in Port Jackson. A fearful tragedy was being enacted in the city about the time we were throwing out our anchor. Eight young men were thrust out of this world into eternity from the gallows. These men had made a quarrel with the blacks at Miall [sic] Creek, and had killed twenty-eight of them; for which barbarous crime they did not long escape the fearful doom that befell them. They hung all day for their own crimes, and as a warning for others to beware of committing such outrages. ${ }^{25}$

Her representation of Aborigines on her inland trip takes a different approach. In the 48 pages that record her travels with Charles Sturt and Governor Gawler from 22 November to 28 December 1839 and her experiences with the Ngarrindjeri and the Meru people, Davies adopts a narrative style laced with racial clichés and the literary devices of a melodrama. She sets the scene from the first words of her account, informing her readers that:

Captain Sturt told me that I was to take up my quarters at Government House until [the exploratory group] returned. At this arrangement I demurred.

"What! do you object to going to Government House?" I was asked.

"No," I said; "but I would much rather go with you."

"What! go among the savages and be killed and eaten by them? You would be a tempting little morsel for them."

This was rather startling to be sure; but then I said:

"Captain Sturt, if you take me I know that you will take care of me, and not let them kill or eat me. I have faith in your protecting care, and I have no personal fear."

“Well said, brave little girl; you shall go, as you are so courageous." 26

The expeditionary group comprised 20 to 30 people and included the colonial marine surveyor in the Department of the Surveyor General, Gawler's assistantprivate secretary, the superintendent of police, aides to Gawler, and Henry Guy Bryan, a house guest of the Gawler family. Inland from the Great Bend of

25 Davies, Story of an Earnest Life, 1881: 85-86. The Aborigines received justice under Crown law officer, John Hubert Plunkett.

26 Davies, Story of an Earnest Life, 1881: 128-129. 
the Murray River (near the present town of Morgan), Bryan was to disappear without trace, while exploring the country with about five other men from the group.

The tourists first travelled overland from Adelaide to Currency Creek, which enters Lake Alexandrina, south-east of Adelaide. Governor Gawler, Charlotte Sturt, Julia Gawler and Davies went aboard one of the three whaleboats and entered the lake via the Goolwa Channel, in preparation for proceeding up the Murray. Despite her lowly position within vice-regal company, Davies proclaimed in her autobiography that she was the first white woman on the Murray River, because she was 'the width of myself nearer to the bows of the boat' than Mrs Sturt or Miss Gawler. Amid episodes that seem to be pure fiction, this configuration may be verified..$^{27}$

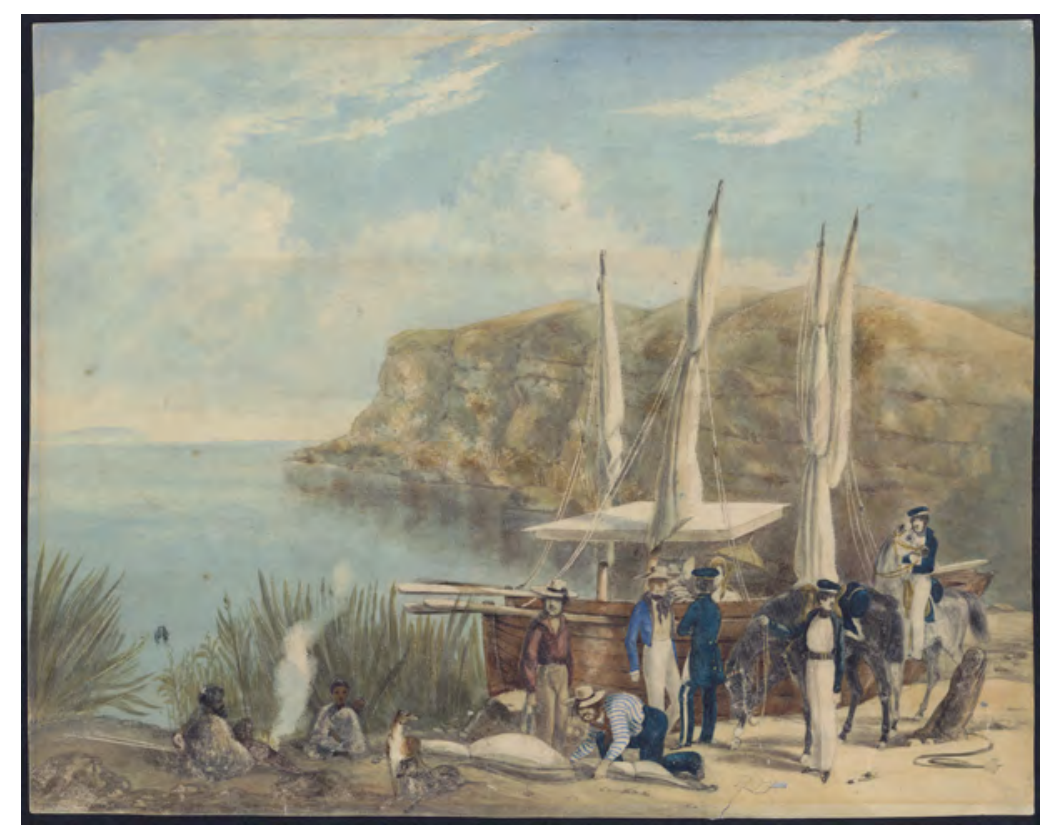

\section{Illustration 5. Eliza Davies in boat, Ngarrindjeri family left foreground.}

Source: John Michael Skipper, 'Extreme point at the junction of the Murray with Lake Alexandrina. Victoria the Lake in the distance. Expedition going up the River, December 1839', PRG 50/34/6, Papers of Lieutenant-Colonel George Gawler, State Library of South Australia. With permission of Ngarrindjeri Regional Authority.

27 Charlotte Sturt and Julia Gawler 'sat with their backs to the stern of the boat'; Gawler and Davies 'sat opposite to each other at the side of it', Davies, Story of an Earnest Life, 1881: 128. The configuration (although a little different) of the three women in the watercolour, 'Extreme point at the junction of the Murray with Lake Alexandrina. Victoria the Lake in the distance. Expedition going up the River, December 1839', (see illustration) may support Davies' claim. The work is also reproduced in Charles Sturt, Mount Bryan Expedition 1839, Sullivan's Cove, Adelaide, 1982, frontispiece. 
Going along with them were two Aboriginal men, the Raminyeri (Ra:Mindjeri) man 'Encounter Bay Bob', and Tom, who would act as the colonists' interpreters. Tom was a Porta' ulun man from Pomanda Point, to the north of Lake Alexandrina. Bob was the colonists' main interpreter; Tom joined the group to act as interpreter between Bob and the northern clans of the Jarildekald (Jeraldkeld), the Ngaralta, the Nganguruku and the Ngaiawang, the latter two being small Meru clans. The language groups of the Jarildekald, Ngaralta, Porta'ulun and Warki were collectively known as the Narrinyeri (Ngarrindjeri). ${ }^{28}$

According to Davies, the Ngarrindjeri men had gathered to offer ceremonial welcome to the exploratory group onto their land. She wrote that, when she first saw the large group, she was filled with 'terror and horror' at the sight of 'painted savages, armed with spears, waddies and towerangs'. Davies shares with the reader that she 'screamed and cowered down in the boat'. Hinting already at providential escape, she is 'saved' by two 'young gentlemen', who take her hands with the words, 'Come, we will guard you'. When she landed,

the yell that escaped from the throats of these nude savages was so terrific that my flying feet hardly ... touched the ground till I reached Captain Sturt's side. The savages were still yelling and beating on their towerangs with waddies. I had never seen savages, and their yells frightened me.

Sturt is said to have consoled her with the words,

Eliza, you have nothing to fear from these savages, they will not hurt you; they have given you a right royal welcome. You are the first white creature with petticoats they ever saw. ${ }^{29}$

Sturt and George and Julia Gawler kept accounts of their experiences-reports against which Davies' exaggerated prose can be assessed. Julia Gawler kept to factual points, while Sturt and Gawler cast an optimistic gaze over the Aborigines, perhaps in the hope of encouraging inland settlement. Sturt recorded that the Ngarrindjeri welcomed Encounter Bay Bob 'in the most cordial manner' and wrote of them that:

They were fine men all of them, with a good and almost European expression of countenance. They were extremely curious and unintentionally though perseveringly troublesome for some time. On the whole, however, they behaved extremely well. ${ }^{30}$

28 Tindale 1974: 212, 214-215, 217-219, and map.

29 Davies, Story of an Earnest Life, 1881: 129. A towerang was a small bark shield.

30 'Captain Sturt's Report', in Sturt 1982: 21. Sturt had reason to think kindly of the Indigenous people. In December 1828, Aborigines had assisted his progress along the Macquarie River in New South Wales. In 1830, he wrote of his 'friendly relations' with the Aborigines that had acted as emissaries between one tribal group and the next to smooth his passage along the Murray River, Flannery 1998: 10; Mrs Napier George Sturt, Life 
Julia Gawler, whom Davies presents as having landed before the arrival of the large Indigenous group, merely noted in her diary: 'Saw some natives, and one of the men started a kangaroo, but it hopped off, and we saw no more of it'. ${ }^{31}$

Governor Gawler, while acknowledging the part played by white overlanders in inciting racial conflict, concluded that the 'natives are neither a ferocious nor a warlike race. Europeans, reasonably armed, cool and cautious, have little to fear from the worst of them in the worst situations'. He expressed a high opinion of the Indigenous people he met, recording that they were:

lively, intelligent, good-tempered people - full of the general native sense of propriety - doubtful of the disposition of Europeans, of the extent of the powers of their warlike weapons, and consequently often timid.

They behaved ill on one occasion only, and the cause of their misconduct was injudicious treatment on our part. Some of them exhibiting great curiosity and intelligence were admitted freely among the luggage and allowed to handle different articles. The consequence was, that in the evening they were lurking about the camp, and a coat and some other trifling things disappeared. After this event the principle was acted on of not throwing temptation in their way or of admitting them to undue familiarity, and no men could have behaved better or have appeared more grateful for the presents they received. ${ }^{32}$

Davies expounded on the Aborigines' curiosity, mentioned by Sturt and Gawler. While depicting the Ngarrindjeri as 'wild men of the woods' and the 'fiercest savages that roamed the forests' - images that bespoke her American readership - she nevertheless also described the men as seated on the ground, watching with interest as Sturt showed them his watch, a box of matches and the use of the European fishing line and hook.

Davies, however, spent many more words in drawing a picture of an Aborigine (the 'chief' of the tribe) with a 'demon-like ferocious countenance'. In her description, phrenology, racial clichés and melodrama converge. She wrote that:

On a rock above me sat, in solitary grandeur, a grim savage, with a shirt on and a white cockatoo's feather in his hair. He sat aloof, alike from his own tribe and the white invaders, watching with scowling brow and

\footnotetext{
of Charles Sturt, Sometime Capt, 39th Regt and Australian Explorer, Smith, Elder, \& Co., London, 1899: 33. Sturt's 1839 account, despite the tone of perceived racial superiority, similarly expressed admiration for the Ngarrindjeri people.

31 'Julia Gawler's Narrative', in Sturt 1982: 41, 27 November.

32 'Governor Gawler's Letter', in Sturt 1982: 39. Gawler would have been conscious of allaying fears that might hamper settlement.
} 
malignant eye their every act ... He had coarse, frizzy black hair, not wool, standing away from his head like a sombrero or mop; his forehead was so low that his hair and eyebrows nearly met, his head receded from front to back, so that his head behind was enormous in size; his eyes were large, black, deep-set, glittering and fierce, and overhung by beetling, shaggy brows; his nose large and flat; his mouth huge, with gleaming teeth; his lips thick and hanging ... he was a picture of ugliness that fascinated me, but when he moved his great glittering orbs from one side to the other ... and moved his thick lips, I felt sick, as if he were about to tear me to pieces and eat me.

She assumed the man's moral depravity with the rhetorical question: 'Who knows what his dark mind was cogitating, when he sat alone in his ugliness on the rock?'. ${ }^{33}$

\section{'Spell-bound with horror ... at the disgusting scene'}

Like many other visitors to the Australian colonies, Davies incorporated a description of a corroboree into her writing. Her account combines factual details with subjective expressions of disgust and horror.

Without understanding the importance of reciprocity in Aboriginal life, ${ }^{34}$ Davies nevertheless understood and acknowledged the concept. She wrote that:

No doubt music hath charms to soothe the savage. One of our party had a flute, and after frightening these fierce denizens of the woods, excited their curiosity, and finally quieted and subdued their excitement, and they were seemingly charmed listeners to the dulcet strains.

The savages had been well entertained by the whites, and they returned the civility by showing us their war-dance. ${ }^{35}$

However, ignorant of Indigenous ceremony, Davies assumed that 'war' was the essence of the entertainment. She adopted corresponding language and tone to describe what she saw as a dance of savages:

There were two parties of savages, one painted white, the other red. They were nude, with long white or red stripes down their arms and legs and across their ribs: their faces and heads painted with white and red

33 References from Davies, Story of an Earnest Life, 1881: 129-130, 135.

34 Cf. Berndt 1980: 35.

35 Davies, Story of an Earnest Life, 1881: 131. 
ochre, were hideous. Spears, waddies and towerangs were their weapons (a waddy is a knotted club about twenty-four inches long; a towerang is a small bark shield). In this terrific garb the men were arranged on either side of the fires. One of each party advanced, a red one and a white one, toward each other, struck waddies, sang and gesticulated, and kept time to the music made on the skins. Another pair advanced, struck and crossed spears, then struck the towerangs. Another pair advanced and another, till all had entered the lists. Then was pandemonium let loose; nothing could be more horrible. The glittering eyes rolled around, showing little but the whites; their huge mouths were wide open, and their teeth were gleaming, and their big red tongues were hanging out. Their disgusting, hideous gestures; their skeleton-like bodies leaping over and around the fires with their terrific yells, are things never to be forgotten ... When they had finished their horrible fiendish dance, they marched up with the measured tramp of the warrior. ${ }^{36}$

Davies provided stereotypical descriptions common to the accounts of other observers in other places. Harriet (Mrs Dominic) Daly and Margaret Elizabeth Leigh Child-Villiers Jersey (The Dowager Countess of Jersey) both used the clichés of wildness and savagery. Daly, who was a short-term resident of Palmerston (Darwin) in the early 1870s, described a 'weird' scene resembling an 'unearthly demoniacal orgie' and feathered headdresses of 'true barbaric fashion'. The Countess of Jersey, who visited Port Darwin in 1893, depicted a 'scene [which] might have come out of the infernal regions or of a Witches' Walpurgis Night'. ${ }^{37}$

The latter part of Davies' account suggests plagiarism in the replication of the language and tone used in Thomas Mitchell's description of a corroboree, observed, like Davies, during the 1830s. Mitchell, who explored the Murray and Darling Rivers in 1835 and 1836, recorded Aborigines',

hideous crouching postures, measured gestures, and low jumps, all to the tune of a wild song, with the fiendish glare of their countenances, at all times black, but now all eyes and teeth, seemed a fitter spectacle for Pandemonium ... ${ }^{38}$

\footnotetext{
36 Davies, Story of an Earnest Life, 1881: 131-132.

37 Mrs Dominic Daly, Digging, Squatting and Pioneering Life in the Northern Territory of South Australia, Sampson Low, Marston, Searle \& Rivington, London, 1887: 71-72; Margaret Elizabeth Leigh Child-Villiers Jersey (The Dowager Countess of Jersey), Fifty-one Years of Victorian Life, John Murray, London, 1922: 326. Harriet Daly was the daughter of William Bloomfield Douglas, Government Resident of the Northern Territory of South Australia from 1870-73. The Countess of Jersey was the wife of the governor (1891-93) of New South Wales.

38 Thomas Livingston Mitchell, Three Expeditions into the Interior of Eastern Australia: with Descriptions of the Recently Explored Region of Australia Felix and of the Present Colony of New South Wales, Volume 1, Second edition, T \& W Boone, London, 1839: 247-248, in Ryan, S 1996: 141.
} 
True to the demands of a melodrama, Davies expressed her feelings of being 'spell-bound with horror [as she looked] at the disgusting scene'. ${ }^{39}$

Davies nominated the scene of the corroboree to introduce the popular nineteenth-century literary theme of miscegenation. The idea of a sexual relationship between a white woman and a black man had previously become part of the American version of Eliza Fraser's story. The popular nineteenthcentury American novelist James Fenimore Cooper had developed the topic in The Last of the Mohicans (1826). Davies claimed that, during her travels on three continents, she received many proposals of 'marriage', three of them during the course of the inland tour. On the dark night of the corroboree, however, with the assembled groups - both black and white - gathered closely together, Davies 'felt something grip [her] foot with a tight grasp [whereby she] screamed and staggered back'. She saw a 'hideous', 'wriggling animal' scurrying away and realised that it was the black interpreter, Tom. ${ }^{40}$ Was he perhaps checking if Eliza had legs under her petticoats?

Davies extended this episode, perhaps to bring in her representation of Indigenous courtship practices. She described how, on the day after the corroboree, Tom stealthily, and with waddy in hand, crept towards the unsuspecting Davies, bent on hitting her on the head and abducting her as his 'lubra'. This depicted brush with death was again providentially circumvented when Governor Gawler intervened to warn her.

Feeding the category confusion in current racial debates, expressed by Darwin and Banks, and manipulated by Barnum, as to whether Indigenous people belonged to the supposed lowest form of humans or were at the highest level of apes, Davies included animalistic terms when she described Aborigines. In another of her idiosyncratic episodes, not mentioned by Julia, Sturt or Gawler, she noted that some Aboriginal women were,

uncouth looking creatures. They were hidden away in a nook in one of the cliffs, jabbering at a great rate, just like monkeys, which they very much resembled. They were hideously disgusting. We were afraid of them at first, but they did not offer to hurt us. I patted one of the monkey-like babies, and gained the favour of the mother right away. She grinned, and went through some antics, which were not the most graceful. ${ }^{41}$

Davies referred to the associated ideas of physiognomy and racial hierarchy to compare the physical attributes of Tom ('the ugliest savage of the tribe save its 
chief, who was monstrous ${ }^{\prime 2}$ ) and Henry Bryan. Bryan's idealised image, as fated victim of the 'wilderness', shines in contrast to the depiction of treacherous savagery inherent in Tom's black and ugly body:

Here were two men between whom a greater contrast could hardly be presented. In their physical appearance they were as distant as the poles, both had black hair, black eyes and white teeth. Tom with beetling brows, deep-set, restless, crafty eyes, his black hair red with ochre, and teeth a great mouthful; and though he donned his four shirts after his descent from the tree, he looked every inch a hideous savage. Bryan with black hair waving over a broad, white, intellectual brow, nose slightly Roman, mouth well-formed and fascinating when wreathed in a smile, beautiful white teeth, eyes large, lustrous, speaking, sparkling, seemed to look into you while looking at you; a square chin, a tall, well-formed, athletic figure, handsome and noble ... handsome, hapless, gentlemanly young Bryan. ${ }^{43}$

\section{'Providential escape'}

When given an opportunity to highlight the Aborigines' curiosity, cooperation and sense of fun, Davies instead manipulated a possible first-hand experience with Aborigines into a scene of 'captivity' and providential escape. Here she again follows James Fenimore Cooper, who threaded the excitements of captivity and escape into his novels, which he set within the solitude and danger of the American frontier. ${ }^{44}$ By transposing into the minds of the Aborigines her own interpretation of intent, Davies clearly enters the realm of historical fiction. ${ }^{45}$

Davies writes that, during an evening stroll, she and Julia encountered 20 'nude savages', who gathered around the girls. Davies called this 'an ambush'. Resorting to the kind of language characteristic of survival literature, she used emotive words to build tension - fear from descriptors of ugly 'savages' and the threat of cannibalism; sexual titillation with the picture of nudity and the prospect of a fate 'a thousand times worse than death'. Her introductory statement of the men as 'glistening in grease and war paint, and armed with war weapons' succinctly introduced both prospects. ${ }^{46}$

\footnotetext{
42 Davies, Story of an Earnest Life, 1881: 134.

43 Davies, Story of an Earnest Life, 1881: 145-146.

44 Cf. The Pioneers (1823), a part of James Fenimore Cooper, The Leatherstocking Saga. Cooper was an influential writer whose literary career spanned the years from 1820 to 1850 . His novels ran to many editions and reached a wide readership, being translated from the English versions into French and Italian.

45 Inga Clendinnen argues that, in representing the past, it is impossible to understand or empathise with actions, thoughts or intent, Clendinnen 2006: 19-28.

46 Davies, Story of an Earnest Life, 1881: 138-139.
} 
The protagonist of a melodrama must share her feelings. Davies felt 'faint and sick' at the 'hideous sight' of the naked men. Instead of running away, she gained inspiration from the source of salvation available to other maidens, whose adventures grace the pages of captivity narratives. For miraculous intervention, she appealed to God: 'in that moment of utter helplessness and terror, I remembered that I had a Father in heaven, Almighty to save, whose arm could shield us'. In the same way as John Curtis reported Eliza Fraser's pleas for salvation, Davies prays, and receives, God's redemptive grace:

In a moment I felt that whatever befell us we were in His hands who doeth all things well. As I looked at the grinning, painted savages, I felt horrified at our helpless state, but I knew that if God did not permit these monsters to harm us, a hair of our head would not be injured, but if God allowed them to kill us, we were still in his hands. I felt secure under His protecting care. I then had no fear, though we were only two helpless girls completely in the power of these painted demons. I felt also that God was very near to protect His poor helpless children. ${ }^{47}$

Davies's sexually-charged images of Aboriginal masculinity and her melodramatic asides suggest potential physical and sexual brutality as if, 'Life and death were in the balance'. Like a damsel in distress, she fears the (unspoken) worst:

Thoughts as quick as lightning flashes passed through my brain; first I feared being killed and eaten; then, O horror! I thought they might not kill us, but what would be a thousand times worse than death, they might carry us away and hide us. ${ }^{48}$

The portrayal of suspense and horror vie oddly with Davies's account of what appeared in her narrative to be a group of innocuous, curious and good-natured Aborigines. She described how:

one of these panther-like monsters came close up to me (they had never seen any creatures like us before, and their curiosity was excited) and took my hand, pushed up my sleeve, and put his great horny hand and arm close to mine. His touch made my flesh creep. He then pushed my bonnet from my face, and put his face close to mine, and looked at my neck. The close proximity of his great jaws and gleaming teeth made me shiver, but when he pulled the dress off my feet to look at them, I gave him a push which drove him from me staggering to a distance, and he nearly fell. This made all the uncouth savages relax and yell

47 Davies, Story of an Earnest Life, 1881: 139.

48 Davies, Story of an Earnest Life, 1881: 139. Davies' melodramatic devices would have been familiar to readers of Samuel Richardson's Pamela (1740). 
most hideously. While Julia and myself were being examined by two of these horrid men, all the others were grinning and looking on deeply interested in the investigation. ${ }^{49}$

Davies was brave enough to interact with the compliant Aborigines, when she demonstrated the use of scissors. The men sat on the ground with 'quiet expectancy' and assented as Davies cut their beards and hair from their heads. Taking the hair as 'a trophy' and 'a memento of our providential escape', the girls bounded 'like two hunted kangaroos' back to the camp.

In keeping with the theme of captivity narratives, providential escape was equated with salvation. Davies therefore wrote that:

We had just had an escape from death with all its torturing details, and, oh, worse than death with all its horrors ... Life, death, eternity, bodily pain, and worse than all these, ten times told, were all presented to our senses ... My heart was full to overflowing with gratitude for our preservation. I thought of my orphaned state, and what would have become of me in the wilds of this great land, if I had not a kind, heavenly Father to protect me. O God, my refuge and defense in a perilous hour! I cried unto the Lord, and he heard my heart's cry, and saved me. It is a good thing to trust the Lord. ${ }^{50}$

Davies made sure that she incorporated the concepts of ugliness, heathenism and the perceived low racial status of Aborigines, writing that these men were:

the worst looking of all the hideous savages of the Murray, or even of the earth. They belong to the lowest types of humanity. They have no idea of an overruling providence. ${ }^{51}$

Her choice of 'panther-like' to describe the Ngarrindjeri conveniently placed the scene in an American landscape.

Julia Gawler made no reference to this episode. Two days earlier, however, she had dispassionately recorded: 'Saw plenty of natives in the camp. Very harmless and quiet'. Several days later, she wrote: 'Plenty of natives, very good tempered men showed their astonishment at every[thing] they saw by calling out "yar" ". ${ }^{52}$ Perhaps by publisher's demands, Davies had been encouraged to resort to melodrama in order to erase the favourable depiction of 'grinning', friendly Aboriginal people.

49 Davies, Story of an Earnest Life, 1881: 139-140.

50 Davies, Story of an Earnest Life, 1881: 141-142.

51 Davies, Story of an Earnest Life, 1881: 142.

52 'Julia Gawler's Narrative', in Sturt 1982: 42, 2 December, 30 November, 5 December. 
Davies' publication in the United States meant that her rendition fitted a current genre of North American captivity narratives, written by women. Western expansion across the United States, particularly after the 1862 Homestead Act, which encouraged and formalised the process of settlement, stimulated stories of the 'wild west'. Hardship, endurance and threat of or actual attack by the Indians became the stuff of folklore. Appealing to her American readers, Davies taps into women's fear of Indian attack at the frontier with her similarly frightening textual pictures of Aborigines. Glenda Riley found that American frontierswomen from 1825 to 1915 portrayed, like Davies, racial biases and distorted perceptions in their interpretations of Native Americans. Riley also found that works that included inferences of sexual mistreatment appealed to a wide market from the time that they first appeared in the American colonial period. The Indian Wars waged in Oregon from 1855 to 1858, during the time of Davies' first period of residence in America, were seen as an example of the so-called inferior race striking out in a deadly fashion against white settlers and their families. Rumours and fears of Indian attack in the state of Iowa continued well into the 1870s - the period during which Davies took up permanent residence in the United States. ${ }^{53}$

\section{Qualified appreciation}

While Davies acknowledged some exceptional Indigenous skills, her praise was expressed in racial terms. Bob and Tom were not only expert language interpreters, they were also indispensable trackers, particularly in their exhaustive searches for Bryan. Davies, however, qualified her report by degrading their ability to 'follow a trail over a naked rock' to the level of animal attributes, describing Bob and Tom as having 'the instinct of hounds', 'the sight of a grayhound, and the scent of a bloodhound'. This stereotype pandered to the expectation of her readers. George Gawler, on the other hand, refers succinctly and objectively, in a letter to his brother-in-law Henry Cox on 20 December 1839, to being led by 'a very intelligent native'. ${ }^{54}$

The Aboriginal men generously shared their knowledge of country. Davies accepted unquestioningly their assistance in finding food during the first stages of the return overland trip to Adelaide, when provisions and water were almost exhausted. Bob identified for the tourists the edible quandong fruit. However, when admiring Tom's 'marvelous' agility at tree climbing, Davies stated that

53 Riley 1984: xv, 81, 39-40; Riley 1988: 10; Jeffrey 1979: 55. Davies' writing was also typical of the nineteenth-century tradition of travel writing, Pratt 1992: 86.

54 Davies, Story of an Earnest Life, 1881: 151, 152; Letter from George Gawler to (his brother-in-law) Henry Cox, 20 December 1839, D 3063(L), State Library of South Australia, re the death of Henry Bryan, the son of Rev'd Guy Bryan, Rector of Woodham Walter, in Essex. 
this skill was 'the agility of an Australian Black' — a reference perhaps aimed to remind readers of the hypothesised link between humans and apes. Both Bob and Tom climbed trees and caught birds for classification by the zoologist, John Gould, and for preservation by a taxidermist, Mr Strange, both of whom had temporarily joined the group for these purposes. ${ }^{55}$ Davies' perfunctory reference to Bob and Tom exposes the previously undervalued or unknown Aboriginal role in early Australian natural science, within the more general sphere of Indigenous people's integral part in advancing modern Australia.

In applauding the ingenuity of boomerang throwing, Davies was following an accepted ethnographic inclusion in colonial works. Giving credit where it was due, however, she wrote that:

The dexterity and precision with which [the boomerang] is thrown by these Blacks is a marvel to the whites. They hurl it so as to strike the object at a distance of over one hundred yards, and it can be thrown so as to return to the thrower. They can make it describe a circle round a tree and strike a looker-on. This singular, simple-looking weapon is found only among the Australians, and it has excited the wonder of all Europeans. It is no less strange than true, that white men have never learned to make or throw the boomerang, though they have made the attempt. ${ }^{56}$

Davies chose to remain ambivalent about the subject of cannibalism. She mooted the possibility that Bryan's 'grave was in the stomachs of the savages', yet her rational voice qualified that idea. She observed that:

Some authors say that the Australian blacks are not cannibals. I believe they were, in the days I speak of, not from actual observation, but from reading and hearing so much of the practice of cannibalism. ${ }^{57}$

The apparent hardship endured on the tour's last days evoked for Davies images of civilisation and Christianity, centring on the colonists' code of a 'high and holy purpose of worshipping the true God', compared with those of the 'pagan' Aborigines. She developed the common nineteenth-century idea of 'wilderness' as an uncivilised, empty environment when she referred to 'the solitude of these spots [in inland Australia] forsaken and alone in their sterility, and weird in their silence'. In language reminiscent of John Curtis' account of Eliza Fraser, Davies

55 Dawes 1991: 88.

56 Davies, Story of an Earnest Life, 1881: 130-131.

57 Davies, Story of an Earnest Life, 1881: 152, 134. 
observed of the trip that, 'We were far away from the habitations of civilized men, in the midst of a wilderness, where the savage roamed in ignorance and moral debasement' ${ }^{58}$

In the 40 years that had elapsed between Davies' experiences and her published version, the social and political constraints that had informed the contemporary accounts of 1839 no longer applied. The fading memories of the Indigenous inhabitants, who had subsequently been subdued or displaced, allowed Davies to weave into her story an exciting account of these formerly 'fierce' Aborigines. For her northern American readers, the veracity of her interpretation of events long past was essentially irrelevant. The free play of Davies' imagination, alongside details that formed the structural background of her life story, resulted in textual ambivalence, in which a factual account of Aborigines vied with a distorted depiction, heavily reliant of literary tropes. Perhaps Eliza Davies had adopted her own ending to the lines in Scott's Lay of the Last Minstrel, which reads: 'I cannot tell how the truth may be / I say the tale as 'twas said to me'.

Under her penmanship, her South Australian story could well be summed up with the words:

'I cannot tell how the truth may be / I say the tale as 'twas [told by] me' 


\section{Queensland Frontier Adventure- Emily Cowl: Excitement and Humour}

'They were wearing my things in a most grotesque and laughable way'. ${ }^{1}$

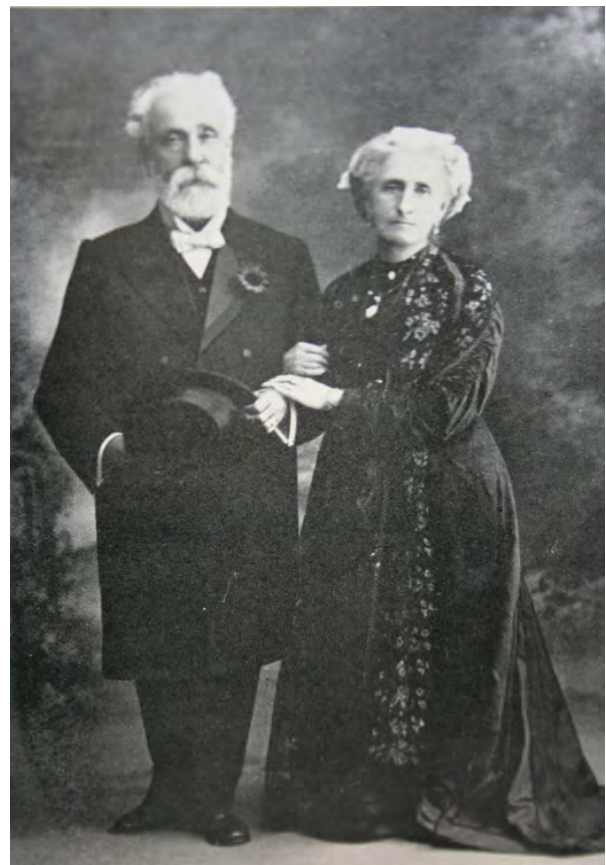

Illustration 6. Thomas and Emily Cowl, 'The Event of their Golden Wedding'.

Source: Mrs T Holder Cowl, Some of My Experiences during a voyage to the Gulf of Carpentaria and three years' residence at Normanton in the early Seventies, Besley \& Pike Ltd, Brisbane, n.d.

Just as Eliza Davies sought to entertain her North American readers with an exaggerated depiction of Aborigines, so Emily Cowl's aim was to evoke the excitement of living amongst Indigenous Australians on the Queensland frontier in the 1870s. Initially presenting her tale to a Pioneers Club in Brisbane, her two lectures were published as Some of My Experiences during a voyage to the Gulf of Carpentaria and three years' residence at Normanton in the early Seventies in about 1912. ${ }^{2}$ Her publisher, Besley \& Pike Ltd, printed works into the mid-twentieth century on politically conservative topics such as the Australian (later Federal)

1 Mrs T Holder Cowl, Some of My Experiences during a voyage to the Gulf of Carpentaria and three years' residence at Normanton in the early Seventies, Besley \& Pike Ltd, Brisbane, n.d.: 28.

2 Just prior to publication, Thomas and Emily Cowl celebrated their fiftieth wedding anniversary. This date was 19 February 1912. As the Cowls lived in Thorroldtown, now the north-eastern Brisbane suburb of 
Country Party and the 1935 Silver Jubilee celebrations of King George V. As well as substantial imperial works relating to World War I and missionary activities in Burma, ${ }^{3}$ publications on sea travel were also produced. It was in this genre that Some of My Experiences found its place.

Emily's text is a complex mixture of stereotypes of Indigenous 'savagery' and enlightening pictures of Aborigines' individualism and humanity. The backdrop to the action is the brutal frontier of colonial Queensland, with the menacing presence of the Native Police. Like Davies, however, Emily enlivened her text with the literary conventions of popular nineteenth-century novels. Although she presents a confused melee of messages, she is so firmly in control of her well worked-over material that her stories and her self-identity are projected with a keen and steady eye on effect. Her prime aim is to entertain her audience.

Unlike Eliza Fraser and Davies, Emily was a long-term colonial resident. As a town-dweller, however, she differs also from the three settlers that follow, by being removed from direct involvement with Aborigines. Comprising 37 pages, Emily's text melds historical details relating to her voyage to northern Queensland and her three and a half years' residence in Normanton with her own version of Aboriginal behaviour, presented in thrilling escapades. These represent the Kurtjar ${ }^{4}$ as opportunistic, daring and fun-loving people, their light-heartedness often aimed at the newly arrived settlers. At the same time, Emily appears to take care to accommodate her audience, many of whom had pastoral connections, by incorporating in her text the presiding racial attitudes that Aborigines must be 'controlled' and white men and women protected from their depredations. The result is an ambivalent picture in which the innocuous Aborigines nevertheless earn the epithets, 'dangerous' and the euphemistic, 'mischievous'. Within this mixed presentation, Emily's own racial attitudes are difficult to discern, remaining masked behind her motivation to amuse and her care not to offend the supposed racial perceptions of her audience.

\footnotetext{
Wooloowin, from 1888 to 1899, and from 1901-1905, the Pioneers Club at which Emily spoke, would appear to have been in Brisbane. In 1900, the Cowls' address was, 'Hyde Park, Townsville', Wise's Queensland Post Office Directories.

3 Owen Wildman, Queenslanders Who Fought in the Great War, c. 1920 and Gordon S Seagrave, Burma Surgeon Returns, 1946, are two examples. Besley \& Pike Holdings Ltd was registered as a public company in Queensland in 1957 as an envelope manufacturer and printer, Jobson's Year Book: Public Companies of Australia and New Zealand, 1972.

4 Kurtjar territory stretched from the coast of Gulf of Carpentaria to the Smithburne River in the south, to the Staaten River to the north, and inland as far as the present homesteads of Delta Downs and Macaroni station. Normanton is situated on the southern boundary of this land. While the Kurtjar have been nominated in this chapter as the representative group in the Normanton region, six other Indigenous groups, including the Areba people, also lived in the area, Charles Bynoe, Memories of Normanton: An Aboriginal Perspective, Normanton State School, 1992, Author's Note: 1-2.
} 
4. Queensland Frontier Adventure-Emily Cowl: Excitement and Humour

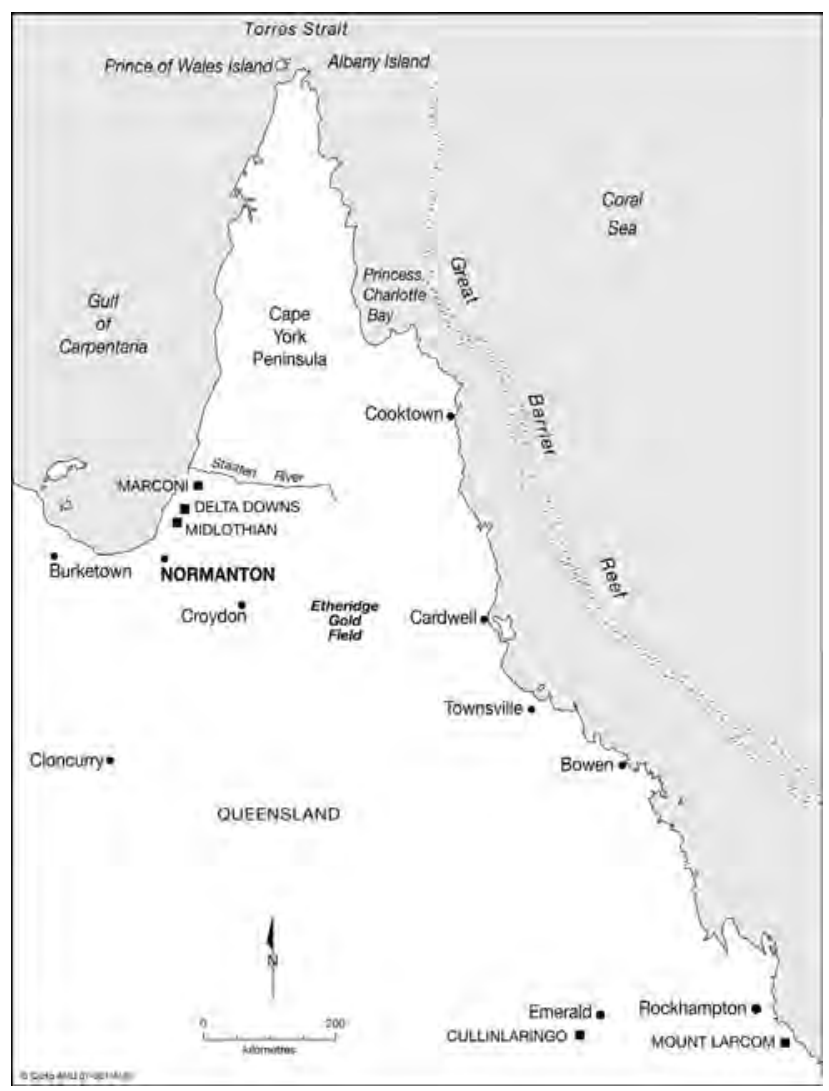

Map 4. Emily Cowl. Northern Queensland showing places mentioned in the text around Normanton near the Gulf of Carpentaria, the Etheridge Goldfield and the Rockhampton district.

Source: CartoGIS, College of Asia and the Pacific, ANU.

Emily took pains to present herself as a respectable, middle-class lady, of sober tastes and tidy habits. These middle-class values she struggled, but succeeded, to maintain in the harsh environment of far northern Queensland. In August 1871 she travelled to Normanton on the Norman River, 80 kilometres inland from the southern coast of the Gulf of Carpentaria, after her husband, Thomas Holder Cowl, had been appointed manager of the Normanton telegraph station. ${ }^{5}$ A civil servant with the Queensland Electric Telegraph Service, and previously based in Toowoomba, Cowl was directed to establish a new branch station in Normanton, oversee the proposed connection through Normanton of a submarine cable from Java and, thereafter, to perform the important task of transmitting telegraphs

5 'Thomas Holder Cowl J.P., telegraph-station master, telegraph-station, Normanton', R R Whitworth Compiled Under the Authority of the Postmaster-General, The Official Post Office Directory (Professional, Squatting, and Trade) of Queensland, F F Bailliere, Brisbane, Sydney, 1874: 154. 
from the wider world to the Australian colonies. Hoping to gain the contract, the Queensland government had approved the construction in June 1869 of an overland telegraph line that traversed Cape York Peninsula from Cardwell on Queensland's eastern coastline. It was opened, in preparation for the overseas connection, in January 1872. The subsequent decision, however, to connect the telegraph along the Port Darwin to Adelaide line, and not through Normanton ${ }^{6}$ resulted in the Cowls' move to Cooktown in March 1875.

In spite of her public persona, Emily's beginnings were comparatively lowly. Born Emily Jane Ferguson in County Fermanagh, Ireland, in 1844, she was the daughter of a cashier. Thomas Cowl, born in Hull on 7 July 1843, appeared to have had similar working class connections. The son of a merchant, his occupation on marriage was registered as 'Purser'. ${ }^{7}$ After Thomas's working life at telegraph stations in the coastal towns of Bowen and Townsville the Cowls retired to their home, Cooyah, in Dickson Street, Thorroldtown, near Brisbane. ${ }^{8}$

\section{Setting the scene}

Adventure was the primary theme of Emily's presentation. Her first talk dealt with the trip from Brisbane along the east coast of Queensland and around Cape York to Normanton. In this initial lecture, which formed the first section of her published work, she set the scene for her first-hand experiences with Aborigines. Revealing her knowledge of the literary tradition of captivity narratives, she referred to the legendary adventures of white men and women who had been castaways after shipwreck and who trusted their lot with the Indigenous peoples of the coastal regions.

Setting sail from Brisbane on 9 August 1871, the Countess of Belmore finally gained favourable winds and a high tide that freed her from a Moreton Bay sandbank, and propelled her into the open sea. As the 60-ton schooner sailed north along the Queensland coast, she passed bays, inlets and towns, which Emily tracked and described. A secondary theme in this part of her story was

\footnotetext{
6 For a discussion on the rivalry between Queensland and South Australia for the Overland Telegraph connection, cf. Bauer 1964, Appendix I: 263-265.

7 Although Emily Cowl's marriage certificate states her age at marriage in Sydney in February 1862 as 22 years, her death certificate records that, on her death on 3 June 1925, she was 81 years of age, suggesting that she married at 17 or 18. On her death certificate, her age at marriage is recorded as 18 years. Emily's birth year can be most closely identified as 1844. Thomas Cowl's stated age of 23 years on his marriage certificate was similarly inflated from his correct age of 18. He died on 24 January 1916, aged 73, New South Wales Births, Deaths and Marriages Registration, Marriage Certificate registration number 1862/000149; Queensland Death Certificates, 1925/B45859 and 1916/427; The Historical Society of Queensland Journal, Vol. 1, No. 2, February 1916: 63.

8 Wise's Queensland Post Office Directory, 1895 to 1900. Thomas Cowl retired in 1900. In 1913, he and Emily lived at 'Balma Carra', Eagle Junction, Brisbane, HSQJ, Vol. 1, No. 1, August 1914: 11.
} 
the primitive nature of the coastal settlements compared with the progress of the ensuing 40 years. Here she weaves into her descriptions of the passing landscape the legends of shipwreck survivors, who were taken in by and who lived among Aborigines in various locations along the northern Queensland coast.

The peril of sea voyages was a theme that had captured the imagination of European writers at least since Daniel Defoe took the marooning of Alexander Selkirk on Juan Fernandez Island in the Pacific Ocean in 1704 and turned it into the story of Robinson Crusoe. ${ }^{9}$ Emily evoked the danger of her own voyage, which took place before 'lighthouses, lightships, buoys and beacons mark[ed] the dangers all along the Inner Route between the Great Barrier Reef and the mainland' ${ }^{10}$ She described how the Countess of Belmore struck the coral reef but was freed by the efforts of crew members.

The association of shipwreck and the mystique of 'captivity' by 'savage' Aborigines was a particularly potent recipe for storytellers. The Eliza Fraser saga exemplified its fascination. Eliza Davies, too, had encountered stormy seas in gales in the Irish Sea, in the Australian coastal waters, and when rounding Cape Horn during her return to Scotland in 1847, fearing shipwreck and, in her case, death in the watery depths. Emily Cowl incorporated the exotic mix of castaway and capture into her narrative with her own examples. She drew attention to the site between Bowen and Townsville where James Morrell lived for 20 years with the Jurn and Bindal people after shipwreck in $1846 .{ }^{11}$ She recounted the story of the Frenchman, Narcisse Pierre Pelletier, who was shipwrecked as a 14-year-old cabin boy on board the St Paul and rescued in October 1858 by members of the Makadamas at Princess Charlotte Bay on the far north coast. He lived for 16 years with the Makadamas until forcibly 'rescued' by a seaman in 1875 and returned to France. He is believed to have returned in about 1881 to live with the Makadamas, remaining with them until his death in the $1920{ }^{12}$

Emily also recalled the fate of Barbara Thompson, ${ }^{13}$ who was rescued after shipwreck in 1844 by the Kaurareg people of Muralag (Prince of Wales Island), off the northern tip of Cape York Peninsula), where she lived with the Aborigines for almost five years. Her story has become part of Australian folklore, replicating although not surpassing, the tale of Eliza Fraser. Emily states that Thompson

\footnotetext{
9 Selkirk requested to be put off the Cinque Ports after quarrelling with the captain and was rescued four years and four months later by William Dampier, Preston and Preston 2004: 313.

10 Cowl, Some of My Experiences, n.d.: 6.

11 Cowl, Some of My Experiences, n.d.: 6. Henry Reynolds cites 17 years, Reynolds 1990: 19.

12 Cowl, Some of My Experiences, n.d.: 9; Murray 1969: 14-15; The Sun, Sydney, 5 August 1974: 14.

13 Cowl, Some of My Experiences, n.d.: 3, 7-8. Barbara Thompson's maiden name, 'Crawford', is the nominated term used by Emily Cowl, who has also heard her name as 'Margaret'. Barbara Crawford had eloped, aged 16 years, with seaman, William Thompson. In October 1849, Barbara was 'rescued' by the crew of the survey ship, H.M.S. Rattlesnake, commanded by Captain Owen Stanley from whom the account was handed down, Goodman 2005: 254-262; Moore 1978: ix, 9, 229-230.
} 
was 'not ... molested or in any way harmed by the blacks. [The Kaurareg] had merely fed and looked after her, taking her with them as they moved from one hunting ground to another'. ${ }^{14}$

Emily's representation of the Yadhaigana people of Albany Island on the northern tip of Cape York Peninsula was of friendly, calm and courteous individuals. When she bartered a piece of tobacco for an Indigenous necklace, she praised the use of 'pretty pieces of nautilus shell'. She admired the 'beautifully made' spears, purchased by the passengers as benign items of trade-transactions that denoted peaceful intent, not warfare. In similar fashion, she described an intricate outrigger canoe, with its grass matting sail and central wickerwork platform, implicitly appreciating Aboriginal ingenuity. She also recorded the generosity and cooperation of the Yadhaigana, who returned to the schooner in the evening with gifts of a turtle and fish, although failing to elaborate on whether the gesture may have emanated from courteous rites of welcome or reciprocal obligation rules. This action replicates the observation of Joseph Banks at Cooktown in 1770 when the Kuku-Yalanji people offered fish to the crew of the Endeavour, after a fish had accidentally been thrown to them. ${ }^{15}$

In this first section of her work, Emily presents her conflicting messages. Along with the accounts of Indigenous care for needy white men and women and the 'intelligent and courageous' Yadhaigana, she also endeavoured to portray the idea of fearsome, dangerous Aborigines who, during the time of the Cowls' voyage in August and September 1871, were said to be lurking in the bushland along the Queensland coast. Emily builds up this picture by referring to the 'numerous and hostile' Aborigines 'hiding in the scrubs'. She expressed to her audience her alarm that she would be 'at the mercy of the blacks' if the passengers were required to land. When the captain and crew went ashore to find firewood on Prince of Wales Island, Emily reported that they were 'well armed, because the natives on the island were well known to be dangerous' ${ }^{16}$ This ambivalent assessment of Indigenous intent is characteristic of her attitude throughout her tale, similarly applied to the second part of her presentation that deals with her adventures in Normanton.

\section{Into isolation and desolation}

Emily and Thomas Cowl arrived in Normanton on 5 September 1871. An outpost of empire, new and remote, Normanton had been declared a town in August 1868. Settlement was established as an alternative site for Burketown,

14 Cowl, Some of My Experiences, n.d.: 9-10; Cf. Darian-Smith 1996.

15 Cowl, Some of My Experiences, n.d.: 12-14; Beaglehole 1962, Vol. II: 92.

16 Cowl, Some of My Experiences, n.d.: 5, 8, 17, 14, 11-14; Beaglehole 1962, Vol. II: 92. 
150 kilometres to the west, after an outbreak of fever, brought by boat from Java in 1866, had decimated that town's population. Building in Normanton began in May 1867 after William Landsborough had navigated the Norman River earlier that year. The town served as a depot for goods transported between the port and the cattle runs and mining ventures in its hinterland. The successes of the recently discovered, although ultimately short-lived, Etheridge Gold Field, 300 kilometres east of Normanton and the Cloncurry copper mines, 400 kilometres south of the town, had contributed to Normanton's growth during the 1860s and 1870s.

Although in October 1868, 43 purchasers of land at auction registered their address as Normanton, in 1871 there seemed to have been only seven residential dwellings, some unoccupied, and a few huts. According to Emily, the European population, including children, was about 40. The town consisted of one long, wide road (Landsborough Street), on which stood the Commercial Hotel, the Prince of Wales Hotel, the Court House and Police quarters, the Lands Office, the Land Commissioner's house, the Telegraph Office (with the Cowls' house attached), and a general store. Residents included the inspector of police, two acting assistant police inspectors, a land agent, customs officer, postmaster, cattle-brand inspector and telegraph officers, working under Thomas Cowl. ${ }^{17}$ Among these male officials, Emily was one of the few women in the town, a factor that she utilised to enhance the interest of her story.

Emily's descriptions of Normanton as 'almost beyond the pale of civilisation' and 'far, far away from the comforts of civilisation' brought into focus the isolation into which a respectable urban resident had been cast. She depicted it as a 'wild, unsettled' place with 'many hardships to be endured', manipulating its desolation and remoteness by inflating the distances from Cloncurry and Townsville. ${ }^{18}$ The themes of isolation and hardship tie into the idea of exile and wilderness, which in nineteenth-century literature was associated with the concept of Biblical banishment into which colonists brought the progress of civilised society and British law.

Her attitudes to landscape also complied with the current European perceptions of Australian scenery as barren and unattractive. While confirming the characteristic northern Australian estuary country of 'low mangrove swamp and salt pans', Emily described the environment around Normanton as 'devoid of scenery' in contrast to the 'lovely scenery of Toowoomba'. She depicted the flat terrain as boggy and mosquito-infested in the wet season, and bleak and barren in the dry season, except for sporadic clumps of coarse spinifex. ${ }^{19}$ Emily

17 Cowl, Some of My Experiences, n.d.: 20; Normanton Centenary 1868-1968, 1968: 5; The Official Post Office Directory of Queensland, 1871: 125.

18 Cowl, Some of My Experiences, n.d.: 2, 31.

19 Sullivan 1996: 4-5; Cowl, Some of My Experiences, n.d.: 2, 18; Normanton Centenary 1868-1968, 1968: 5. 
seemed to compare the sterility of Normanton with the civilised landscapes of the surrounding pastoral properties that had spread north from the Moreton Bay region from the 1830s. The underlying themes of hardship, danger and isolation at Normanton came together in Emily's first image of the town: the funeral of a young woman who had died from the complications of childbirth, because of the lack of medical care. It was in this frontier existence that hazardous adventures were waiting to happen!

In Normanton during the 1870s, disease and death were close at hand. The Norman River was crocodile-infested and fevers were rife. Emily wrote that she was to suffer from intermittent malarial fever for 17 years. The practical part she played in the civilising process was to bring into this inhospitable environment her medicine chest, along with her considerable resourcefulness, endurance and fortitude. She illustrated her success in medical emergencies with examples of her capable application of remedies and her overall expertise. Her intervention (unspecified by detail) in a case of threatened miscarriage, for instance, ensured that mother and baby were saved. This example-as well as the earlier reference to death in childbirth-reminded her audience of the tragedy that might befall women who ventured onto the desolate frontier of colonial Queensland. ${ }^{20}$ Despite her succumbing to malaria, Emily leaves no doubt in the reader's mind that she is equal to men in robustness and enterprise, whatever her location.

Tony Roberts both confirms and qualifies the Cowls' medical skills. In Frontier Justice, Roberts relates that a traveller on his way to Normanton in November 1871 sustained multiple fractures to his collarbone after his horse bolted and dashed him against an overhanging branch. In agony, the horseman arrived in Normanton, where 'the Telegraph Master tried to set my bone but after six tries he gave up, telling me to go to the Bay (600 miles) ${ }^{\prime} .^{21}$

To highlight the harsh environment of Normanton, and as a way to promote her public image, Emily referred to her previous genteel activities in Toowoomba where she enjoyed Christian fellowship in the company of her respectable female friends. Although both married and buried with Presbyterian Church rites, she taught in Church of England Sunday schools, recalling with pride the social success of some of her former pupils. ${ }^{22}$ The only Christian clergy to visit Normanton was a Catholic priest to whom Emily extended an ecumenical

20 Nikki Henningham has examined public concerns in the years following Federation about the suitability of women to live in tropical regions and the effect that might have in maintaining a 'White Australia', Henningham 2001: 311-321.

21 Reeves 1985: 171; Roberts 2005: 34.

22 Two prominent Queenslanders, who were children in Toowoomba between 1868 and 1871, were Henry Littleton Groom (1859-1926), member of the Queensland Legislative Council for 16 years, and his brother, (later Sir) Ernest Littleton Groom (1867-1936), member of the House of Representatives for Darling Downs, succeeding his father, William Henry Groom, D B Waterson, 'Groom, William Henry (1833-1901)', ADB, NCB, ANU, http://adb.anu.edu.au/biography/groom-william-henry-3675text5741, accessed 2 November 2013. 
welcome. Otherwise, her Christian identity relied on the recounting of her past religious duties in Toowoomba. Together with wifely devotion, sobriety, cleanliness, and a Protestant work ethic, her allusions to religion project an image of a lady who has been cast out of a civilised environment onto a wild frontier.

\section{Tying the text to history}

In her representation of the wild, uncivilised existence in Normanton during the 1870s, Emily evoked a past time in Queensland's history. Her story, set before the Aboriginals Protection and Restriction of the Sale of Opium Act 1897 (Qld) (amended in 1899 and 1901), harked back to the period before Indigenous people were settled on reserves in the manner practised in other British colonies, including North America and South Africa. ${ }^{23}$ In the early years of the twentieth century, Aborigines were rarely the topic of public concern, remaining out of sight and out of mind of city dwellers. The Brisbane Courier in 1905, for example, focused its attention on matters of the Australian Commonwealth, the British Empire, and news of the wider world, opened up by the electric telegraph. ${ }^{24}$ Emily revived this historical amnesia by projecting images of Indigenous people in their 'native' state. On her northerly voyage, for example, she depicted the 'uncivilised' Yadhaigana people as 'all quite naked, [with] not a stitch of clothing of any kind on men, women, or children' ${ }^{25}$

Racial conflict forms the backdrop to her story. The writers of Creating $A$ Nation represent the frontier of white settlement in the Australian colonies as 'a place of fear and desire, of struggle and survival where indigenous people and colonisers came into contact, interacted and clashed'. ${ }^{26}$ According to Raymond Evans, 'both sides [of the Queensland frontier] bristled with weaponry. The passions of fear, anxiety and vengeance were running high ... and European attitudes towards Aborigines as the hated and despised "other" were intense'. G S Lang wrote in 1865 that in Queensland there was "more destruction of the blacks in occupying new country than in any other colony'. ${ }^{27}$ Aborigines died violently from the time when settlers ventured inland from Moreton Bay in search of new country for grazing and agriculture in the 1830s and 1840s. In 1841, for example, over 50 Aborigines were poisoned by flour laced with

\footnotetext{
23 Queensland Government Gazette, 16 December 1897: 1387-1394. According to Edward Palmer, Aborigines were still living 'in their original state' on Cape York in 1903, and 'on some of the rivers flowing into the Gulf [were] still numerous', Edward Palmer, Early Days in North Queensland, [Angus \& Robertson, Australia], Queensland Classics edition, 1983 [1903]: 214.

24 Based on research of the Brisbane Courier, January to May 1905.

25 Cowl, Some of My Experiences, n.d.: 13.

26 Grimshaw, Lake, McGrath and Quartly 1994: 131.

27 Evans 2003: 63; Palmer 2000: 45.
} 
strychnine on Kilcoy station in the upper Brisbane Valley - killings that added to Indigenous resentment towards the British, already developing after their 1836 contact with Eliza Fraser and the other Stirling Castle castaways on Great Sandy Island to the north-west. ${ }^{28}$

Certainly, racial attitudes in nineteenth and early twentieth-century rural Queensland reflected the turbulent history of race relations in that colony. To build up her picture of perceived Indigenous savagery, Emily recounted the precautions taken by white settlers against Aboriginal attack, stating for instance that: 'All who left the town for the bush carried arms. It was not safe when travelling to camp alone'. Telegraph line repairmen worked in pairs for protection and travellers venturing outside Normanton made a practice of sleeping some distance from their camp fire, so as to disguise their actual location at night. Correspondence to the Colonial Secretary supports Emily's evidence. In 1874, officials based in Normanton wrote that it was 'positively unsafe to be out of doors after nightfall unless provided with firearms'. There were also fears that Aborigines would burn the town. Roberts, too, provides examples of white men afraid to travel alone during the 1870 s for fear of Aboriginal attack. ${ }^{29}$

\section{Appeasing the audience}

Emily's audience at the Pioneers Club most likely consisted of people who considered themselves to be superior members of colonial society and superior especially to Aborigines. Pioneers Clubs formed from ideas about national identity, which heightened during the 1880s. The concept of an Australian identity had begun around 1872 with the development a 'political training ground for the Australian-born' - the Australian Natives Association. Indicative of growing nationalistic sentiments, its membership by 1886 had risen to over 4,000 in nearly 60 branches. This early national feeling incorporated the notions of an 'Australia for the Australians' ${ }^{30}$ and the exclusion from citizenship of 'aliens' such as the Chinese. National pride and exclusiveness therefore went hand and hand, and the development of Pioneers Clubs following the federation

\footnotetext{
28 Evans, Saunders and Cronin 1993: 49; Yarwood and Knowling 1982: 195. Elaine Brown refers to a 'tradition of resentment towards Eliza Fraser' passed down to the Indigenous descendants of her rescuers, Brown 2000: 118.

29 Cowl, Some of My Experiences, n.d.: 29; Evans, Saunders and Cronin 1993: 45; Reynolds 1993: 49; Roberts 2005: 34, 38.

30 Coined by an Australian Natives Association (ANA) member. The ANA, membership of which was confined to white Australians born in Australia, grew out of the Friendly Society of Victorian Natives, Buxton 1977: 204-205.
} 
of the Australian colonies on 1 January 1901 epitomised this marriage. The imperial attitude of white racial superiority necessarily prevented Indigenous people from being considered worthy of inclusion. ${ }^{31}$

The attitudes of separate racial identity and racial superiority found in the language and style of Some of My Experiences were therefore closely aligned to the supposed inherent values of Emily's assembled audience. She very likely pitched her representation of Aborigines in response to an expectation that her listeners were sympathetic to the views of settlers that saw Aborigines as barbarous subhumans without ethics or compassion.

The Pioneers Club that Emily Cowl addressed appears from her tone of reference to have consisted of female pioneers. An inclusive voice of mutual understanding with her audience, in relation to such feminine matters as a knowledge of female undergarments, the dangers of childbearing (although Emily herself was childless), and the foibles of husbands who knew nothing of the culinary arts, indicates a sharing, not only of cultural, but also of gender knowledge. She nevertheless adopted a 'Boy's Own' style of adventure writing, popular among men and women alike, to entertain her audience. This type of writing tapped into the nationalistic feelings of patriotic citizens of the newly established Commonwealth of Australia.

\section{'Exciting' escapades}

Physically separated from the Kurtjar, and not reliant on them as workers, Emily represented them as nuisances, who entered the town to pilfer 'buckets, tubs, pots, axes, tomahawks, clothes lines, anything portable'. ${ }^{32}$ This observation complies with contemporary reports of the prevalence of Aboriginal looting in Normanton, a local official writing that, in 1874, 'nearly every house in the town' had been robbed..$^{33}$ To amuse her audience, however, Emily also included humorous anecdotes of Kurtjar daredevilry and sense of fun.

One example of theft was of four ducks, hanging from the Cowls' veranda, awaiting a Sunday roasting. This occurred during the four to five monthslong wet season, when food supplies ran low for blacks and whites alike. Ancestral memory and current research have established that the Kurtjar were largely coastal and river dwellers, heavily dependent on fishing. During the wet season, fishing became difficult because the Kurtjar were forced to move

\footnotetext{
31 Lark and McKenzie 1988: 1, 3; Memorandum of Association of the Australasian Pioneers' Club, H J Gurd and Co., Sydney, 1915: 3-4. The term 'White Australia Policy' had been first enunciated in the Brisbane radical newspaper, the Boomerang, in 1888, Donegan and Evans 2001: 98.

32 Cowl, Some of My Experiences, n.d.: 27.

33 Evans, Saunders and Cronin 1993: 45.
} 
to higher ground away from the coast. After colonisation, competition with superior European weaponry in the hunt for available food resources increased the Aborigines' vulnerability to hunger and malnutrition. ${ }^{34}$ In the case of the white settlers, impassable roads meant that fresh provisions could not arrive, so Thomas Cowl resorted to shooting wild birds for the table. Displaying an ethnocentric attitude typical of white settler discourse in which Aborigines were seen to encroach on spaces 'owned' by settlers, Emily recalled that:

On this occasion ... [we] reserved two pairs [of ducks] for ourselves and gave the rest away. I plucked and prepared ours ready for Sunday and hung them under the back verandah in a cool place in front of our bedroom window. We left the window open when we went to bed, trying to get the room cool. Soon after midnight, we were lying awake feeling half dead in the sultry heat; the moonlight was streaming in the window; we saw a blackfellow fully armed with spears, etc., make a grab at the ducks; the string with which they were tied did not break, so he quickly snaped [sic] the legs with his fingers, and made off with the ducks - leaving the feet only for us. ${ }^{35}$

While the language of petty theft, the evocation of stealth, and the suspense of midnight lurking create an atmosphere of danger in Emily's retelling, the deed is nevertheless represented as having been performed quietly and innocuously.

The return of the Kurtjar a few weeks later provided Emily with her piece de résistance. She portrayed the moment with the immediacy of colloquial language and the tension of suppressed fear, recounting to her audience that:

We were in bed, my husband asleep, and there was no moon. Presently black forms appeared at the window. I awoke my husband and whispered to him not to move. The least motion in the curtains would have attracted the attention of the blacks who were armed with spears, and could easily have speared us where we were lying in bed. My clothes were on a sort of settee, placed under the window just as I had taken them off when retiring. We saw the blacks lean over the window-sill, take possession of all my clothes, and make off. ${ }^{36}$

Thomas Cowl ineptly gave chase. More successful were the Native Police, the armed and mounted Aboriginal policemen, led by European officers, who operated in the 'unsettled districts' against Indigenous peoples. As a selfgoverning British colony, Queensland had its own Native Police force, established under the guidance of the Commissioner of Police following the passing of the

34 Bynoe 1992: 1-2, 24

35 Cowl, Some of My Experiences, n.d.: 27.

36 Cowl, Some of My Experiences, n.d.: 28. 
Police Act of 1863. Operating as a cheap form of law enforcement, it performed a similar role to various native mounted forces in African colonies and the native irregular cavalry in India. It had 'no powers of law enforcement or crime prevention except in the case of indigenous people, and it actively participated in dispersion and decimation'. Notorious in Queensland, the Native Police force was, according to the nineteenth-century historian, William Rusden, a 'machine for murder' ${ }^{37}$ During the early 1870s, two detachments of Native Police were stationed at Normanton.

When the Native Police found the Kurtjar,

They were wearing my things in a most grotesque and laughable way. One black fellow had on a certain garment of mine (no combinations in those days). I will leave to your imagination the result. Just fancy his black skin showing prominently - in the opening below the waist band of my white garment. A black gin had laced up my corsets and was wearing them on her head as a helmet and my stockings on her arms; another had on a skirt, another my bodice and no skirt, my chemise worn by another, and so on. This laughable description was given to my husband by the police officers. ${ }^{38}$

By referring to her 'drawers' and corset, Emily appears to have eschewed, in the interest of a good story, the strict moral code of modesty beholden of respectable women. Her sexual innuendo aims to titillate and perhaps shock her audience, and suggests that ladylike propriety was relevant only whilst in mixed company.

The Native Police 'punished' the Kurtjar. This term was one of the most common euphemisms for the murder of Aborigines. Emily's reversion to a bland tone of explanation to describe this action indicates her confidence that she is complying with her audience's racial views. In depicting the part played by the Native Police, she may also have been motivated by a utilitarian urge to provide her audience with an accurate account of events.

Emily's story joins a rich literature of colonial reports of Aboriginal response to English clothing. An account by Janet Millett, wife of the Church of England chaplain at York, Western Australia, from 1864 to 1868, comes closest to the sort of hilarity, described by Emily, when Aborigines saw pieces of British female costume. Explaining a Balardung man's reaction to her strange hat, Janet wrote that:

At the sight of me, (Isaac) burst into a loud guffaw, the cause of which was explained by his mistress, who said that I was the only woman

37 Richards 1999: 1-2. Cf. Enders and Dupont 2001: 96-106; Roberts 2005: 259.

38 Cowl, Some of My Experiences, n.d.: 28. 
whom Isaac had ever seen in a black beaver riding-hat, of the shape commonly called in the colony a "bell topper" ... he continued to stare at me and my hat ... and to chuckle merrily to himself. ${ }^{39}$

Emily's third example of Aboriginal pilfering reveals the traits of high spirits and risk-taking, recognised in young men of all cultures and times. She described how some Kurtjar men entered her house while the Cowls were entertaining friends:

[A] party of men were sitting on my front verandah enjoying a smoke. I went inside to fetch something my husband asked for, and caught sight of a couple of black fellows in the half-hall, stealing the coats and hats hanging there. I raised the alarm and chase was given. The blacks were so closely pursued, they threw away what they had taken. They were all recovered, but the blacks got away. ${ }^{40}$

The uselessness of the garments to the Aborigines indicates that the Kurtjars' motivation was not theft, but was driven by an exuberant burst of excitement to indulge in adventure and fun. Given the results from previous bouts of merriment, this escapade showed bravery, if not foolhardiness.

The recognition of Indigenous ingenuity in stealing the cast iron flanges, which were used to hold the iron telegraph poles in the ground, is a surprising admission. Ignorant of the function of the line as a form of white man's communication, the Kurtjar used the iron to construct axes by securing it to a handle with vines and adhesive tree resins. Telegraph wire was similarly removed and used as spear points or as a valuable commodity for bartering. With the removal of the flanges, however, the poles fell down, breaking the line and forestalling Thomas Cowl's efforts to forge colonial progress in the north. Emily's failure to mention retribution is perhaps stranger, although in these cases the culprits were unseen and unknown, and blame unsubstantiated, making 'arrests' difficult. Conversely, Emily's outrage after the petty thefts at her house may have been fuelled by the insult of an intrusion by Aborigines into the sacrosanct spaces of her home, whether veranda, bedroom or hallway.

\section{H Rider Haggard or the American West?}

Emily's final tale, her 'most exciting experience', replicates the sort of 'ripping yarn' of the romance genre of 'New Imperialism' adventure tales, popular between 1875 and 1914. H Rider Haggard, Robert Louis Stevenson and Rudyard

39 Mrs Edward Millett, An Australian Parsonage or, The Settler and the Savage in Western Australia, Facsimile Edition, UWA Press, Nedlands, 1980 [1872]: 87.

40 Cowl, Some of My Experiences, n.d.: 28. 
Kipling's stories and, in Australia, Rolf Boldrewood's Robbery Under Arms ${ }^{41}$ are examples. By 1895, in a survey from an English school library, Haggard had far surpassed Sir Walter Scott in reader popularity. ${ }^{42}$

Robert Dixon has described these romantic adventures as 'a willed re-assertion of an imperial ideal on the wane' and declares that renewed vitality in the British race was most promising at the colonial frontier on the 'outskirts of Empire', where the 'machine is relatively impotent and the individual is strong' ${ }^{43}$ Characteristically romantic adventures of vigorous manhood, novels of the New Imperialism incorporated a masculine code of adventure and vitality. In Emily's exciting tale of escape from pursuing Aborigines, she chose to take equal precedence in the action with her husband-both partners fitting the stereotype of ennobling and invigorating figures at the outpost of British Empire and endeavour, in the mould of Haggard's protagonists.

Emily writes that, while enjoying an idyllic picnic, she and her husband were startled by an apparent Aboriginal 'attack' :

Suddenly my eye caught sight of several large rolly-pollies of grass moving on the opposite side of the river towards the bank. We watched them for a few moments, then my husband exclaimed. "By Jove, wife! There's something wrong there - they are rolling against the wind." "Yes," I said, "and look - what are those black objects not far from yonder bank? Look! - each roll stops on the bank and then another black object can be seen in the river. See! - the objects are coming nearer - they are blackfellows swimming this way, evidently to attack us in this lonely place." Quick as thought we threw everything into the buggy, caught the mare, got her harnessed up were jumping on board when the first black made his appearance on the bank, our side of the river, a few hundred yards away. Others soon joined him.

They took a short cut for the Bluff under which we must pass by a more circuitous route to avoid being bogged in the salt pans. It was a race for life. If they reached the bluff first we were helpless. They would be above us - could hide, shower their spears and heavy stones upon us. Quite a number of blacks; they ran their quickest; we lashed our mare

\footnotetext{
41 Rolf Boldrewood (Thomas Alexander Browne), Robbery Under Arms, first published in serial form by the Sydney Mail in 1882; and in book form by Remington, London, 1888.

42 In a list of books taken from a school library in a single term, published in Longman's Magazine in 1895. No details of the name or location of the school are provided, H Rider Haggard, She: A History of Adventure, Macdonald \& Co., London, 1969 [1886], Introduction: p. xxi.

43 Dixon 1995: 62, 2-3.
} 
until she galloped like fury, covered with white foam. We managed it. Got under the Bluff and passed, just as they began to ascend. We were safe. $^{44}$

Replicating Haggard's literary style, Emily builds suspense by the use of short, sharp sentences and emotive expressions of panic. While Haggard's works are 'saga-like stories of adventure', Emily compressed her tale into a potted account, in which she imitated the tone of Haggard's 'dramatic vitality' by resorting to the same literary devices of 'rapid narrative, abundant incident, fertility of invention, and a strong sense of dramatic effect' ${ }^{45}$ After the chase, the heroes emerge happy and safe from the black man's potential brutality and subterfuge.

The elements of the chase and split-second escape in this tale are also reminiscent of formulaic American Western adventures: the Cowls flee for their lives just as American frontiersmen fled from Native Americans in stories of the Wild West. Emily appears also to have adopted the landscape associated with northern American stories of escape, incorporating craggy outcrops and, curving beneath them, a winding track on which white victims were open to Indigenous attack, and beyond which they raced to freedom.

The idea of the hostile alien on the other side of the frontier is a literary convention, independent of the reality of contact in different localities. For the sake of a good story, Emily has connected to this ingrained perception. Obscure as she was, Emily was not the first writer to have exaggerated, even lied, for effect: William St Clair's biography of the novelist and adventurer Edward John Trelawny observes that Trelawny invented stories about his life in the navy, refers to his 'daring deception' and notes that the 'lies acquire a life of their own'. ${ }^{46}$ Malcolm Elwin, writing in the introduction to She, states that the 'fanciful improbabilities of Haggard's romances derive[d] from the habit of imaginative speculation developed during his years in Africa' ${ }^{47}$

Clara Sue Kidwell's discussion on the creation of myth shows how historical reality was obscured in the case of the Native American women, Pocahontas (who 'saved' the life of John Smith, leader of the Jamestown colony), Sacagawea, the leader of the Lewis and Clark expedition, and Dona Marina (La Malinche), Cortés' mistress. According to Kidwell, American Indian women have been converted in literary reconstruction to the stereotypes of 'hot-blooded Indian princess, a la Pocahontas, or the stolid drudge, the Indian squaw plodding behind her man'. Kidwell points out, however, that these are 'not real people'.$^{48}$

\footnotetext{
Cowl, Some of My Experiences, n.d.: 29.

Haggard 1969 [1886]: xviii, xix, xii.

St Clair 1977: 1.

Haggard 1969 [1886]: vii.

Kidwell 1992: 98.
} 
Like the representations of Native American women, Emily's image of treacherous Aborigines complied with Australian colonial settler values. Her audience and later readers would have been receptive to the idea of Aboriginal attacks on unsuspecting couples or family groups. Emily, however, may have sought inspiration in one such event. In 1875, the year that the Cowls moved to Cooktown, Aborigines killed William and Elizabeth Conn on their farm near Cardwell, 400 kilometres south of Cooktown. These notorious murders were 'talked about for years and written about for decades' ${ }^{49}$ In what seems to be her contribution to the now vast collection of historical fiction, Emily was perhaps fantasising that, 'This is how it might have happened to me'.

Whatever the historical or literary basis of Emily's tale, the denouement of her story involved brutal retribution against the Kurtjar by the Native Police. According to Emily, these police contingents "punished [the Aborigines] severely - or rather, to use the correct phrase "dispersed" the tribe to which they belonged'. 'Dispersal' was, like 'punishment', another nineteenth-century euphemism for 'murder'. Striving to embrace the supposed attitude of her audience, Emily writes: 'You will understand how troublesome and dangerous the blacks were in those days' ${ }^{50}$

Emily's projection of the Kurtjar as dangerous and violent is unsubstantiated in other parts of her narrative, where no actual attack, injury or death occurred at the hands of the Aborigines. The only injuries mentioned in her text are a gunshot wound to the hand of a white man, shooting at the Kurtjar, and a damaged leg, when Thomas Cowl chased Aborigines in his bare feet, revolver in hand, and fell over a log. Tony Roberts' research verifies low European mortality rates from Indigenous attacks in the Gulf Country. Whereas the known murders of Aborigines were numbered in the hundreds, Roberts cites the deaths of Europeans by Aborigines from 1874 to 1901 to be 21 . None of these involved women or children. The unprovoked nature of the portrayed potential attack on the Cowls, while fitting the British perception of savage Indigenous behaviour, has been found by Roberts to be an element seen rarely in Indigenous culture. ${ }^{51}$

\section{Kurtjar point of view}

In contrast to Emily's exciting tales in which malignant Aborigines terrorised white settlers, two direct descendants of the Kurtjar present a different story.

\footnotetext{
49 Richards 2008: 28; Jones 1961: 201-202.

50 Cowl, Some of My Experiences, n.d.: 29. For other common euphemisms for 'murdered' cf. Reynolds 1996 [1987]: 48-50.

51 Roberts 2005: 263-264. Roberts found that the majority of attacks on Europeans in the early years of contact resulted from the interference of white men with Aboriginal women, Roberts 2005: 108.
} 
Collective ancestral memories compiled by Charles Bynoe in Memories of Normanton, and Rolly Gilbert, born in about 1901, have identified the pressures on the Kurtjar people after settlers began to compete with them for sources of food and freshwater. The Aborigines were driven away from their hunting grounds and their freshwater 'soaks', which they had dug for their own use. Privations, exemplified by the theft of Emily's soon-to-be-roasted ducks, became acute at the end of months of flood when food supplies were depleted and when all inhabitants, whether black or white, strove to survive in the landscape's boggy aftermath..$^{52}$ Emily provided an insight into Kurtjar need with her report that domestic fowls and pigs were popular targets for theft.

Indigenous memory confirms Emily's reference to the attacks made on their people by both settlers and the Native Police force. This period, beginning in the late 1860s, is remembered as the time of 'no good', when hundreds of Kurtjar men, women and children were killed by Europeans. Sometimes, the Native Police massacred whole camps. Gilbert's 'The Massacre at Wamakee' provides a graphic account of white men's killing of Aboriginal men and children. Some of the women were abducted by the men, only to be killed when signs of pregnancy became obvious. Any children who might have been born from these liaisons were killed at birth. Evidence of violent Aboriginal deaths, noted in Roberts' Frontier Justice, confirms Indigenous reports that the Gulf Country was a wild and dangerous place for Aborigines well into the twentieth century. Gilbert succinctly summarised: 'We were unhappy because the white people were bad'. ${ }^{53}$

Gilbert described those white landholders, who handed out flour and sugar to make damper, as 'good' ${ }^{54}$ The Cowls, however, would not have qualified, either in location or generosity. Emily was essentially a townswoman, venturing only occasionally outside the town's confined limits where, as she explained, she felt that she was likely to be at the mercy of threatening Aborigines. She had no direct contact with the Kurtjar, considering them as outsiders that disturbed the local peace, albeit at times amusingly.

\section{Conclusion}

Like Eliza Davies, Emily Cowl presented her exciting experiences at the frontier about 40 years after the events. While Davies engaged her readers with

\footnotetext{
52 Bynoe 1992: 2, 26; Melba Casey and Rolly Gilbert, 'Kurtjar Stories', School of Australian Linguistics, Darwin Institute of Technology, 1986: 66.

53 Bynoe 1992: 2, 24; Gilbert, 'The Massacre at Wamakee', 'Living with the White Man', in Casey and Gilbert 1986: 77-80, 91; Roberts 2005: 1-2, 232-233, 258, passim.

54 Casey and Gilbert 1986: 64-65.
} 
melodramatic language and exaggerated images of a 'different' type of humanity, Emily entertained her audience with humorous anecdotes, and with a story replicating a currently popular genre of frontier adventure tales. One enduring literary trope included in both texts (imitating the archetypal Eliza Fraser story) was 'providential escape'. Emily's suspenseful race against death was depicted, like Davies' miraculous salvation, as a lucky escape from fearsome Aborigines.

Although Emily Cowl assumed racial difference and highlighted a dangerous black-white frontier, her humorous accounts showed Aboriginal people as non-violent individuals. The ambivalent picture presents to the reader the disquieting image of settler violence aimed against frivolous and essentially harmless escapades, emanating from Indigenous high spirits and sense of fun. While Emily's own sense of humour could identify with the fun, she nevertheless compromised her tone in deference to the perceived expectations of her audience, and possibly her conservative publisher. To make her experiences palatable to her audience, Emily has deemed it wise to serve them on the imperial salver of British superiority. The representation of Aboriginal people therefore vacillates between vivid examples of Indigenous risk-taking, ingenuity and sense of the ridiculous to stereotypical interpretations of their dangerous, savage habits, worthy of the white man's retribution.

Because Emily was a town resident, who had refused any contact with Aborigines - she had declined to employ Indigenous domestic help-she was unable to bridge the gap to interracial understanding that characterised the writing of the three pastoral women, whose work is investigated in the following chapters. Emotionally distant as well as physically separated from the Kurtjar, she failed to accept them as people. By way of contrast, Jane Bardsley, a Normanton woman who lived on Midlothian station, north-east of Normanton, after her marriage to Thomas Atherton in 1895, interacted with the Indigenous women on whom she relied for help in household tasks - a shared endeavour which developed into a friendly female relationship. ${ }^{55}$ Excluded from Emily's day-to-day experiences, the Aborigines were seen essentially as unwelcome intruders, who frequently encroached on what Emily perceived to be her own territory within the confines of Normanton. Having been insulated and isolated from the Kurtjar, she fostered an empathy with her audience and failed to identify with the Kurtjars' plight.

The appeal of Emily's presentation, however, depended on the power of her exciting stories, which she was determined to portray. In spite of her attempts to impose a contrary interpretation, Emily's selected episodes provide insights into the relaxed attitude of the Kurtjar towards the white settlers in the

55 John Atherton Young (ed.), Jane Bardsley's Outback Letterbook Across The Years, 1896-1936, Angus \& Robertson Publishers, North Ryde, NSW, 1987. 
Normanton region during the 1870s. Although expelled from their land and already experiencing the nutritional privations that were later to debilitate the race, Emily's chosen examples depict the Kurtjars' non-violent actions and reactions in the face of colonisation. At least some of the Kurtjar could exhibit the hilarity of ridiculing British customs.

In spite of the clear vision of easygoing, carefree Aborigines, the strength of the colonial discourse of dangerous Aborigines prevailed in Emily's story. As if to quash any misunderstanding in her contradictory presentation, she included a reference to her own encouragement to exact retribution against the 'troublesome' Aborigines. Implicit in Emily's depiction, however, is Aboriginal authority, vibrant despite the settlers' attempts to control Indigenous actions with retributive violence against apparently innocuous behaviour. 


\section{Part B}

\section{Settlers: Changing the Racial Landscape}





\section{An Early, Short-term Settler- Katherine Kirkland: Valuable Insights Through the Silences}

'I put him in a basket and hung him at my side, as I had seen the native women $\mathrm{do}^{\prime}{ }^{1}$

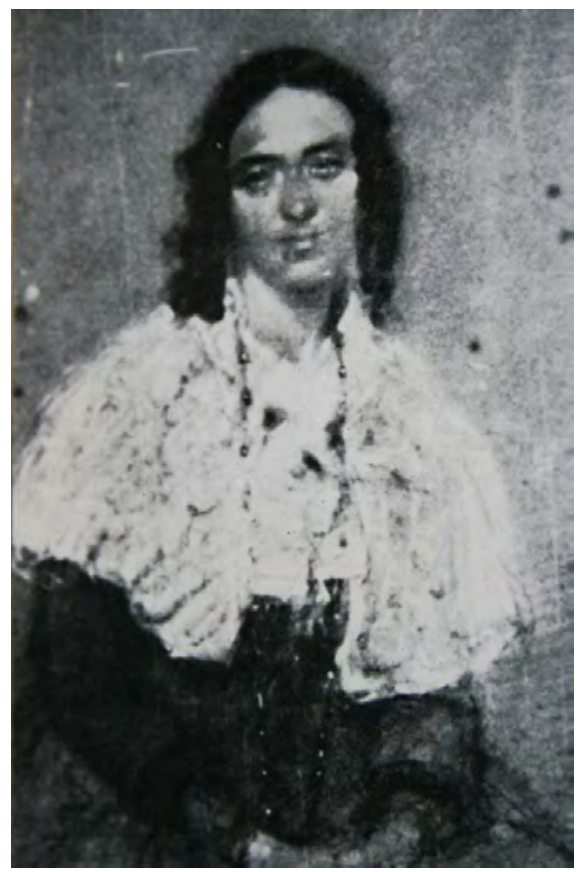

Illustration 7. Katherine Hamilton, later Kirkland.

Source: Hugh Anderson, The Flowers of the Field; a history of Rippon Shire together with Mrs Kirkland's Life in the Bush for Chambers's Miscellany,1845, Hill of Content, Melbourne, 1969.

1 Katharine [sic] Kirkland, Life in the Bush, published by Kenneth W. Mackenzie, "Trawalla", Beaufort, Victoria, c. 1995: 15-16; reprinted from Chambers's Miscellany of Useful and Entertaining Tracts, William and Robert Chambers, Edinburgh, Vol. 1, No. 8, printed in 1844. 


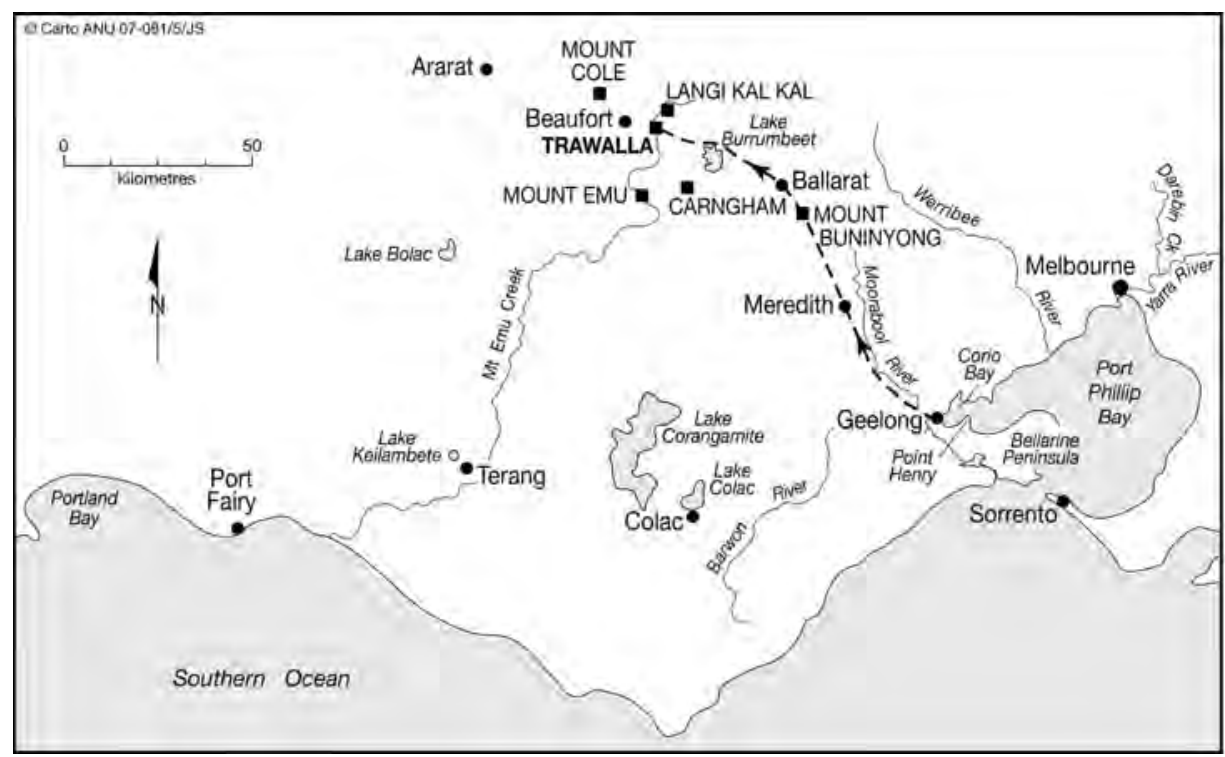

Map 5. Katherine Kirkland. South central Victoria west from Melbourne including route taken by Katherine Kirkland to Trawalla.

Source: CartoGIS, College of Asia and the Pacific, ANU.

Just as Indigenous authority shone through in the literary representation of Emily Cowl, so too did Wathaurong curiosity and humour, pride in country and authority over their land find their way into the work of the short-term settler Katherine Kirkland.

Like Eliza Davies, whose five-week exploratory tour took her through Indigenous lands, Katherine Kirkland entered the country of the Wathaurong (also known as Watha wurrung or Wada warrung) in 1839. For a little over two years, she lived among the Moner balug clan at Trawalla, now in the Western District of present day Victoria. Unlike Davies, who waited for 40 years before publishing her memoir, Katherine's story appeared soon after her return to Britain in September 1841. Her memoir 'Life in the Bush' appeared anonymously as five serialised articles in volume XI of William and Robert Chambers' penny weekly magazine, Chambers's Edinburgh Journal, from 18 June to 16 July $1842 .^{2}$ In 1845 the complete text was published in the popular Chambers's Miscellany of Useful and Entertaining Tracts. ${ }^{3}$

2 Correspondence to Professor Pike from John Kirkland Wilson, great-grandson of Katherine Kirkland, 7 December 1965, 'Katherine Kirkland Biographical File', Australian Dictionary of Biography files, ANU Archives, Noel Butlin Archives Centre, Canberra.

3 Chambers's Miscellany, Vol. 1, No. 8. The date of the edition in which Katherine Kirkland's 'Life in the Bush' appeared is usually cited as 1845 . 
Because Katherine was an early female chronicler of Australian colonial life, she lacked precedents that might guide her own representation of interracial experiences. Publishing her work in Britain for a local readership, she was careful to project herself as a respectable, middle-class lady, amazed and sometimes disgusted at the 'wild' and 'strange' life she encountered in the colony. Her authorial identity of 'A Lady' (the accepted nom de plume for nineteenth-century women writers), protected her anonymity in her references to connections with Aborigines - a subject that might compromise her respectability. It also distinguished her from her readership, a large percentage of the targeted audience being the British working class. She further guarded her privacy by adopting the surname, 'Thomson', before discarding the thirdperson voice for the immediacy of a first-person narration. While hiding her own and her husband's identity throughout her story, she nevertheless divulged the names of her daughter, brothers, neighbours and friends.

Without the passing of time to qualify or adjust her impressions, or to incorporate religious dogma or scientific theories of race that might give her text strength and purpose for eager readers, Katherine offered fresh images of Aboriginal people - although often couched in cautious terms to preserve her image. Somewhat episodic, her commentary is believed to have been based on the letters sent to her mother. ${ }^{4}$ This first-hand, snapshot account of settlerIndigenous relationship holds valuable historical insights of the time before the rapid decline in the population of the Wathaurong by the mid-1840s. Instances of Indigenous reaction and adaptation to white incursion emerge distinctly from Katherine's restrained prose.

\section{From bustling Glasgow}

Born Catherine Hamilton in Glasgow, Scotland, on 23 February $1808,{ }^{5}$ Katherine was the second child of her family, a twin sister of Gilbert, and second eldest daughter of 14 children. Her childhood and early adulthood were spent in Glasgow where, as the daughter of a merchant, her life was tied to the activities of a city that, during the first decades of the nineteenth century, exemplified the mercantile energy of the flourishing, progressive, industrial British economy. Civil service and civic enterprise were part of Katherine's family heritage, her paternal grandfather, Gilbert Hamilton, having been provost of Glasgow and a

4 Information from Mrs Agnes Crossley, grand-daughter of Robert Hamilton in Anderson 1969: 187, note 1.

5 Katherine Kirkland's birth was registered as 'Catherine', Eaves Walton \& Stewart, Legal \& Historical Research papers, in 'Kirkland Biog. File', ANU Archives. Her death notice registers her name as 'Katharine'. Secondary sources and family members refer to either 'Katharine', or 'Katherine', the spelling that I have adopted. Cf. also, Jean Hagger, 'Kirkland, Katherine (1808-1892)', ADB, NCB, ANU, http://adb.anu.edu.au/ biography/kirkland-katherine-2312/text2997, accessed 5 March 2013. 
founder of the Glasgow Chamber of Commerce - a first in the British Isles. When thrust onto a colonial frontier, Katherine showed the corresponding family traits of enterprise, energy and enhanced organisational skills.

On 14 April 1835, Katherine married Kenneth William Kirkland, two years her junior, the youngest son of a family that owned a large Glasgow sugar refinery. Established by Kenneth's grandfather, John Kirkland, it was reputed to be the first sugar refinery in the British Isles. Before emigrating, Kenneth worked in the family business under the management of his eldest brother, Alexander, 12 years his senior. Family testimony suggests that Alexander's overbearing and autocratic attitude towards Kenneth motivated his decision to emigrate.

Katherine and Kenneth Kirkland, their two-year-old daughter, Agnes, Katherine's brothers, James and 18-year-old Robert, set sail from Greenock on the barque, Renown, on 8 June 1838, bound for Van Diemen's Land. Accompanying the family were fellow Scots, Sandy and Mary Forrester. The group travelled north to Launceston, the four men, including Forrester (who was later employed as a shepherd), sailing to the mainland in October 1838 in order to 'secure a sheepfarm'. The Eurocentric attitude to sheep-farming is reflected in Katherine's comment that people simply 'planted themselves as sheep farmers'. Katherine, Agnes, and Mary Forrester, who later (reluctantly) became Mary's servant, stayed at a farm near Launceston, where Katherine 'gained some insight into dairy management and other branches of rural economy' in preparation for her future role as economic helpmate to her farming husband. ${ }^{6}$

Kirkland and the Hamilton brothers were among the earliest seekers of land in the Western District of Port Phillip. The first prospective settlers had pushed inland in 1836 to take up their runs on Wathaurong land. The earliest in the Geelong area were Dr Alexander Thomson, George Russell, and David Fisherlater manager of the Derwent Company, previously the Port Phillip Association. Russell was the founder and manager of the Clyde Company, set up to organise finance for the establishment of pastoral properties in the hinterland of Port Phillip. ${ }^{7}$ In December 1838, Kirkland and James Hamilton purchased 200 ewes and 20 wethers in preparation for settlement at Trawalla, situated on Mt Emu Creek, 40 kilometres west of Ballarat. Over time, their stock numbers grew to 20,000 sheep and 200 cattle. Young Robert Hamilton went to work as overseer at nearby Burrumbeet station. ${ }^{8}$ While both the Kirklands and James Hamilton later returned to Britain, Robert remained and was to become a notable pioneer of the district.

6 Kirkland, Life in the Bush, c. 1995: 1, 2.

7 Croll 1937: 19; Brownhill 1955: 9.

8 R V Billis and A S Kenyon, Pastoral Pioneers of Port Phillip, Second Edition, Stockland Press Pty Ltd, Melbourne, 1974 [1932]: 250; Brown, P L (ed.), Clyde Company Papers, Vol. III, 1841-45, Oxford University Press, London, 1958: 233; Kirkland, Life in the Bush, c. 1995: 37. 
On 21 January 1839, Katherine joined the menfolk. ${ }^{9}$ Arriving with her husband at Point Henry, on the southern coast of Port Phillip Bay, she landed from the brig Henry - moored 400 metres offshore because of a sandbank - first by way of a boat and then carried ashore by her husband. There was no pier. The stock, horses and small animals (goats, pigs, geese, ducks, hens and rabbits) landed in similar fashion: the bullocks were hoisted in the air with a belt and pulley and pulled along beside a boat; the sheep were thrown overboard to make their own way to shore. Ten kilometres away, the nascent settlement of Geelong consisted of three stores, the inhabitants of the village living in tents and rough shacks.

The Kirklands joined a wave of Scottish immigrants who were arriving during the later years of the 1830s, many of them, like the Kirklands, via Van Diemen's Land. In 1839, there were 1,664 such arrivals. Ballarat resident, Nathan Spielvogel, termed the influx, 'the Glasgow Invasion'.$^{10}$ This established network of west-coast Scots gathered at Point Henry to help the Kirklands disembark, load their own drays with the Kirklands' farming equipment and provisions and act as their guides during the seven-day trek inland. By 1839, land had been settled so far to the north and west that the run at Trawalla was 130 kilometres inland. Katherine could legitimately claim that, at the time of their settlement, she was the 'first white woman who had ever been so far up the country'. ${ }^{11}$

\section{First impressions}

Katherine's narrative deals with first contact experiences. Recognition of difference is the theme of the early part of her narrative, which begins with the sentence, 'The wilds of Australia present at this time some strange scenes'. The idea of uncivilised wilderness around the shores of Port Phillip Bay evoked for her a 'primeval solitude', where settlers lived a 'strange kind of life' and (compared with genteel Glasgow) a 'wild kind of existence'. Aborigines enter her

\footnotetext{
9 Alexander Romanov-Hughes (compiler), Coastal Passengers to Port Phillip, 1839, Romanov-Hughes, Taradale, Victoria, 1995, NLA men 1351.

10 Boys 1959: 99; Nathan F. Spielvogel, ‘When White Men First Looked on Ballarat', NLA MS 3776; Weston Bate, 'Spielvogel, Nathan Frederick (1874-1956)', ADB, NCB, ANU, http://adb.anu.edu.au/biography/ spielvogel-nathan-frederick-8607/text15033, accessed 9 March 2013.

11 Kirkland, Life in the Bush, c. 1995: 9. This claim is supported by a contributor in 1853 to Thomas Francis Bride's edition, Letters from Victorian Pioneers: A Series of Papers on the Early Occupation of the Colony, the Aborigines, Etc, Lloyd O'Neil Pty Ltd, South Yarra, Victoria, 1983 [1898]: 182, that '[i]n 1839 the squatters in Portland Bay District were very limited in number, not exceeding a dozen'. Though not signed, Bride noted (p. 197) that the letter had 'evidently been written by Captain Foster Fyans'; and by Isaac Hebb, who lived in the Western District from the time of his arrival as a one-year-old in 1853 until his death in 1939. Hebb's research found that, in 1839, there were only three squatters' wives residing in the area between Port Fairy and Colac, south of Trawalla: Mrs Alexander Dennis, Mrs Hugh Murray and Mrs Thomas Manifold, Hebb 1970 [1888]: 60.
} 
narrative as surreal beings like characters in a novel. She wrote that, 'Occasional adventures with the savage aborigines streak the loneliness of the picture with something like the hues of romance'. ${ }^{12}$

Katherine fell back onto the literary record to describe a landscape lacking the structures and visual cues of a developed Western society. Well educatedbelieved to have attended boarding school until at least the age of $19^{13}$ - she alluded in her text to the words in the English classics. In this case, it was the concepts of barrenness, emptiness and loneliness in Robinson Crusoe that provided the literary construct on which to evoke the strangeness of her surroundings:

When landed, we looked like a party thrown on a desert island, the shore was so barren, and not a trace of human habitation to be seen, or any of the works of man. All was in a state of nature. ${ }^{14}$

On arrival Katherine was dismayed at the uncouth appearance and habits of some of her fellow Scots. She described George Yuille, a recent immigrant, whom she had known in Glasgow, as:

such a strange figure. He had allowed his beard to grow to a great length; he wore very rough-looking clothes, and a broad black leather belt round his waist, with a brace of pistols stuck in it. ${ }^{15}$

Though understated, this is her first textual reference to male violence.

Katherine was also disgusted by the Aborigines' appearance. She first saw them while staying at David and Charlotte Fisher's farmhouse, situated on a hill near the Barwon River - a site now close to central Geelong. ${ }^{16}$ Here the Wathaurong were curious, friendly and unafraid. Katherine wrote that, 'They kept peeping in at the windows to see us, and were always hanging about the huts'. Charlotte Fisher explained that these people were 'civilised natives' and that they were 'always about the place'. Katherine's opinion was that:

12 Kirkland, Life in the Bush, c. 1995: 1-2.

13 Correspondence to Pike from Wilson, 7 December 1965, 'Kirkland Biog. File', ANU Archives. The length of her school attendance may have been because she attended a kind of 'Finishing School' to complete her education.

14 Kirkland, Life in the Bush, c. 1995: 3.

15 Kirkland, Life in the Bush, c. 1995: 3. George Yuille was the brother of William who had arrived in Port Phillip in February 1837 and taken up the Ballaarat run in March 1838, Billis and Kenyon 1974 [1932]: 164, 170. 16 David and Charlotte Fisher's house was later referred to as 'the first house in Geelong worthy of the name', Brownhill 1955: 69. 
they are very ugly and dirty. Some of them wore skins sewed together, and thrown over their shoulders; a few of them had some old clothes given them by the settlers; and some were naked. ${ }^{17}$

Her first description of an encounter with a Wathaurong man revealed him to be good-humoured and innocuous. Talking a walk in the bush with Agnes, she reported that:

I was keeping a good look-out for snakes, and was just stepping over what I fancied, by a slight glance, to be a burnt log of wood, but a second look showed me my mistake; it was a native lying on the grass, grinning in my face with his large white teeth. I was rather afraid, but he looked rather good-tempered, and laughed. He seemed to [sic] lazy to move, so I gave him a nod, and walked on, well pleased he did not think it necessary to accompany me home. ${ }^{18}$

At the end of their first day's travel, the Scottish entourage had trekked 40 or 50 kilometres inland, to reach the run of George Russell, near the present town of Meredith. Here some 100 Wathaurong enacted for the Scots a traditional courteous welcome to country, in the form of their corroboree. Katherine's close observation indicates that she had a ringside view of proceedings:

They had about twenty large fires lighted, around which were seated the women and children. The men had painted themselves, according to their own fancy, with red and white earth. They had bones, and bits of stones, and emu's feathers, tied on their hair, and branches of trees tied on their ankles, which made a rushing noise when they danced. Their appearance was very wild, and when they danced, their gestures and attitudes were equally so. One old man stood before the dancers, and kept repeating some words very fast in a kind of time, whilst he beat together two sticks. The women never dance; their employment is to keep the fires burning bright; and some of them were beating sticks, and declaiming in concert with the old man. ${ }^{19}$

As the linguist and anthropologist T G H Strehlow has noted, Aborigines had been 'trained from childhood to share what they possessed with others, and to co-operate with others in the expectation that others would in turn cooperate with them'. He described a corroboree as a form of expression realised 'in deeds, not words'. ${ }^{20}$ Anthropologists Ronald and Catherine Berndt also identified the importance of reciprocity in Aboriginal life. Their research found

17 Kirkland, Life in the Bush, c. 1995: 4 (italics in original).

18 Kirkland, Life in the Bush, c. 1995: 4.

19 Kirkland, Life in the Bush, c. 1995: 5.

20 Strehlow 1956: 20. 
that responsibility for others formed the basis of group existence, and that reciprocity signified the willingness to cooperate and to extend mutual help. According to Catherine Berndt, 'One of the strengths of Aboriginal society was its emphasis on co-operation in all aspects of living - between persons and between groups, within a defined area where the intermeshing of rights and duties made up a rich social fabric' ${ }^{21}$

When the Wathaurong 'were very anxious that we white people would show them how we coroberied', George Yuille was nominated to present the white man's ritual, performing a Scottish dance and reciting a 'piece of poetry, using a great many gestures'. The Wathaurong 'watched ... most attentively, and seemed highly pleased'. ${ }^{22}$

Like Katherine's first meeting with the Wathaurong man, the corroboree opened another door to cultural confusion. Totally failing to understand Indigenous culture or needs, the Scots gave the Wathaurong 'some white money' and, maintaining British courtesy, politely bade them goodnight before returning to George Russell's humble hut.

'First impressions' were also having an impact on the Wathaurong. On the morning after the corroboree, curious and friendly Indigenous family groups came to investigate Katherine and Agnes and, more particularly, their clothing. Katherine recorded a delightful, perhaps essentially female, interchange:

Numbers of natives came this forenoon to see us. They examined my dress very attentively, and asked me the name of everything, which they tried to repeat after me. They were much amused with my little Agnes, and she was as much pleased with them. I wondered what her grandmamma would have thought, could she have seen her in the midst of a group of savages, and the life of the party. Whenever Agnes spoke, they all laughed aloud, and tried to imitate her voice; the pickaninny leubra's dress was well examined. I put a little night-cap on a native baby, with which its mother was much pleased, and many a little black head was thrust out for one also. ${ }^{23}$

As a newly arrived Scottish lady, Katherine would have been careful to maintain what Penny Russell has described as the 'display of gentility'. Keeping up appearances by 'genteel performance' was of paramount importance to middleclass women, and particularly for Katherine, who was in the early stages of

21 Berndt 1980: 35.

22 Kirkland, Life in the Bush, c. 1995: 5.

23 Kirkland, Life in the Bush, c. 1995: 5-6 (italics in original). The use of 'pickaninny' (also used by Eliza Davies) appears to be part of the lingua franca of the British Empire. 'Piccaninny' referred to a Negro child in Negro pidgin English and stemmed from the Portuguese 'pequenino' (very little), Macquarie Dictionary, 1981. J C Hamilton, Pioneering Days in Western Victoria, n.p., n.d.: 4, tells a similar story. 
pregnancy. She was certainly overdressed in the open bullock dray that took her along bumpy tracks in the heat of summer. She admitted that she 'could scarcely bear' the heat and nearly 'died of thirst' ${ }^{24}$

Ladies travelling in the 1830s, particularly if they were new arrivals, dressed formally, as deemed by British codes of respectability. When Elizabeth Fenton (born Knox) journeyed in 1830 from Hobart to her new home in New Norfolk, Van Diemen's Land, she lamented that her fashionable black satin boots were ruined on the rough, muddy roads. Even colonial-born women were expected to dress appropriately in public. Louisa Atkinson, who was born in 1834 near Berrima in the Southern Highlands of New South Wales, wore practical, 'unfeminine' clothes in the bush, instead of conventional long skirts, a move from proper dress codes that scandalised the locals. ${ }^{25}$

Female clothing served to maintain a woman's position within the English class system. A 'refined' appearance not only identified her own status but also allowed her to identify other women of her class. It also nominated by implication her possession of the middle-class virtue, 'morality'. ${ }^{26}$ Penelope Selby of the Station on the Yarra Yarra did her best to maintain proper procedure. On 26 January 1841 she confided to her sisters in England that, inside the house on hot days, she wore a shift, cotton gown, stockings and shoes, but seemed to reassure her family that, in the evening when it was cooler, she resumed full dress, with all her petticoats. In 1851, Louisa Meredith's sister-in-law criticised Louisa's flouting of society's dress rules, when she wore a 'jacket affair' and a 'dowdy looking bonnet' when out riding. ${ }^{27}$

Colonial men, by contrast, had soon adapted their clothing to accommodate the heat and outdoor activities of country life. John Cotton, of Doogallook station, 80 kilometres north of Melbourne, arrived in the colony in 1843 and wrote in January 1844 that:

We cannot be too lightly clad during this hot weather ... A waistcoat is quite a superfluous vest here and I seldom wear anything over my shirt during the heat of the day. Braces, too, are thrown on one side, and a leather strap round the waist answers the purpose ... [Cabbage-tree] hats ... are generally worn throughout the colony; a handkerchief, tied loosely around the neck, with white or other trousers, socks and shoes ... complete the costume. ${ }^{28}$

24 Russell 1994: 58-59; Kirkland, Life in the Bush, c. 1995: 6.

25 Mrs Fenton's Tasmanian Journal 1829-1830, Sullivan's Cove, Adelaide, 1986: 63; Swann 1929: 18, cited in Clarke 1988: 40.

26 Altick 1973: 174; Schneewind 1970: 99.

27 Frost 1984: 119; Rae-Ellis 1979: 114-115.

28 R V Billis and A S Kenyon, Pastures New: An Account of the Pastoral Occupation of Port Phillip, Stockland Press Pty Ltd, Melbourne, 1974 [1930]: 247. 
Little girls like Agnes, however, were constrained to suffer along with their mothers in similarly elaborate clothes. Katherine's clothing consisted of a series of layers, both on the outside and underneath. Tightly laced corsets pulled in a tiny waist above a wide skirt. Neck ruffs and frilly sleeves were popular forms of ornamentation. Shawls were an essential part of outdoor attire, as were bonnets. Decorative large veils of lace, embroidered net or figured gauze were often worn draped over the sides and back of the headdresses, particularly when travelling. Girls would usually have a pinafore over the top, sometimes trousers underneath, as well as their petticoat. Like their mothers, they wore frilly caps or fussy bonnets. Short ankle boots with side-buttoning or lacing might also have been worn by girls as young as two-year-old Agnes. ${ }^{29}$

On her return trip from Melbourne to Trawalla three months after the birth of her son in September 1839, Katherine met the same Aborigines, who came to investigate her baby boy:

One morning I got into a little hut with the roof half off; it was empty, and I thought I could wash and dress my baby more comfortably than in the dray. I had not been long in the hut when we were surrounded by natives, all anxious to see what we were about. One or two of the women came into the hut, and touched the pickaninny cooley, as they called it: they seemed much amused at his different pieces of dress, and all the little black pickaninnies tried to cry like him. ${ }^{30}$

Like his mother and sister, the two-month-old Kenneth Kirkland would have been encased in layers of clothing. A basic layette in the early nineteenthcentury, consisted of four little shirts, four little caps, two frocks, two bedgowns, two flannel blankets, two rollers, two pairs of 'stays' and flannel coats, two upper petticoats and 24 napkins. In the 1830s, a baby in Britain wore an upper petticoat, wide flannel band wound around its abdomen and hips, a long frock with a low neck, short bodice and short puffed sleeves tied round with a ribbon and bow on the shoulder, flannel pants over the diaper napkins, and socks. Newborn babies were carried around in an extra square of flannel and may also have been draped in a fine knitted shawl. They wore, day and night, plain undercaps and decorative 'outer' caps. Over the cap was a silk-lined hood, with a rosette of satin ribbon in the front, for a girl, and on the left, if a boy. Katherine's observation that little Kenneth was a 'delicate baby' but that, in the

29 De Courtais 1988: 116; Kiddle 1983 [1961]: 90; Cunnington and Buck 1965: Plate 22, opposite p. 149; 163, 166-167, 195, 198, 203.

30 Kirkland, Life in the Bush, c. 1995: 13-14 (italics in original). Like 'piccaninny', 'cooley' also appears to have been part of the language of empire. Probably a variant of the western Indian tribal name, 'koli', it was the Indian term for an unskilled native labourer and, elsewhere, for a labourer employed for cheap service, and possibly a variation of the Tamil term 'kuli' for 'hire' or 'wages', Macquarie Dictionary, 1981. 
words of Laurence Sterne, 'God tempers the wind to the shorn lamb', reinforced the probability of her attention to warm clothing. ${ }^{31}$ The Aborigines had good reason to be amused.

Aboriginal babies were simply carried around in the warm cloak of the mother, hanging at her shoulder. William Russell (1830-1914), the Chief Man of the Gundungorra of the Burragarong Valley, west of Sydney, recalled his mother's 'carrying me on her back cuddled down in a fold of her 'possum rug folded across her shoulders, I felt quite safe and comfortable, as any young Burru (Kangaroo) in his mother's pouch'. By the 1870s, in the Braidwood area of New South Wales, a blanket had replaced the animal skin, but the same combination of cloak or blanket and maternal body heat sufficed to keep the baby warm, protected and comforted. Alice Duncan-Kemp noted that, in the warmer climate of Queensland's Channel Country, newborn babies were carried in the mother's coolamon or fish net, but still kept close to the maternal body, with the head rubbing against the mother's side or back. ${ }^{32}$ Katherine was later to adopt this method for carrying Kenneth.

\section{Trawalla: A shared home}

An addendum to Katherine's text by Robert Hamilton tells how sanguinely the settlers took over Indigenous land as their own. Henry Anderson from the nearby Mt Emu run directed Kirkland and the Hamiltons to 'a pretty spot on the Mt Emu creek'. ${ }^{33}$ The Moner (Kalkeknerkneet) balug clan ${ }^{34}$ told the Scots that it was called 'Trawalla', meaning 'flood', 'much rain' and 'wild water'. Bailliere's 1865 Gazetteer describes it as possessing 'magnificent sites for reservoirs of an extensive character, the available water being pure and plentiful'. Spring-fed waterholes in the creek, one of which reaches a depth of six metres, were a constant water source. After rainfall, these waterholes join up to form a fastflowing stream. ${ }^{35}$ Here the Kirklands established a 40,000-acre sheep station. The homestead site, on the banks of Mt Emu Creek in its northern reaches, was

\footnotetext{
31 As stated in requirements for a newborn of 'poor lying-in women', The Lady's Economical Assistant, in Cunnington and Buck 1965: 147, 148-151, 153; Kirkland, Life in the Bush, c. 1995: 15.

32 Cf. Louisa Atkinson, Sydney Mail, 19 September 1863, in Lawson 1989: 53; William Russell, My Recollections, The Oaks Historical Society, Camden, NSW, 1991 [1914]: 10; Mary Moore-Bentley, Journey to Durran Durra 1852-1885: A Story of the Bentley Family and the Gold Rush Era, Jeanne M Bow, Connells Point, NSW, 1984: 19; A M Duncan-Kemp, Our Sandhill Country: Nature and Man in South-Western Queensland, Angus \& Robertson Ltd, Sydney, 1933: 144.

33 Kirkland, Life in the Bush, c. 1995: 37.

34 Within the Wathaurong territorial name there is thought to have been from between 14 and 25 smaller clans, who traversed a wide area in groups of up to 100 in response to seasonal food sources, ceremonial obligations and trading relationships, Clark 1995: 169.

35 Massola 1968: 48; Banfield 1955: 189; R Brough Smyth, The Aborigines of Victoria: with Notes Relating to the Habits of the Natives of other Parts of Australia and Tasmania, George Robertson, Melbourne, 1878,
} 
also the focal point for the Moner balug. Middens of freshwater shells at the edge of the watercourses attest to its importance as a rich source of food. Other Wathaurong clans used Mt Emu Creek as a north-south route for travelling to and from meetings and ceremonies. ${ }^{36}$

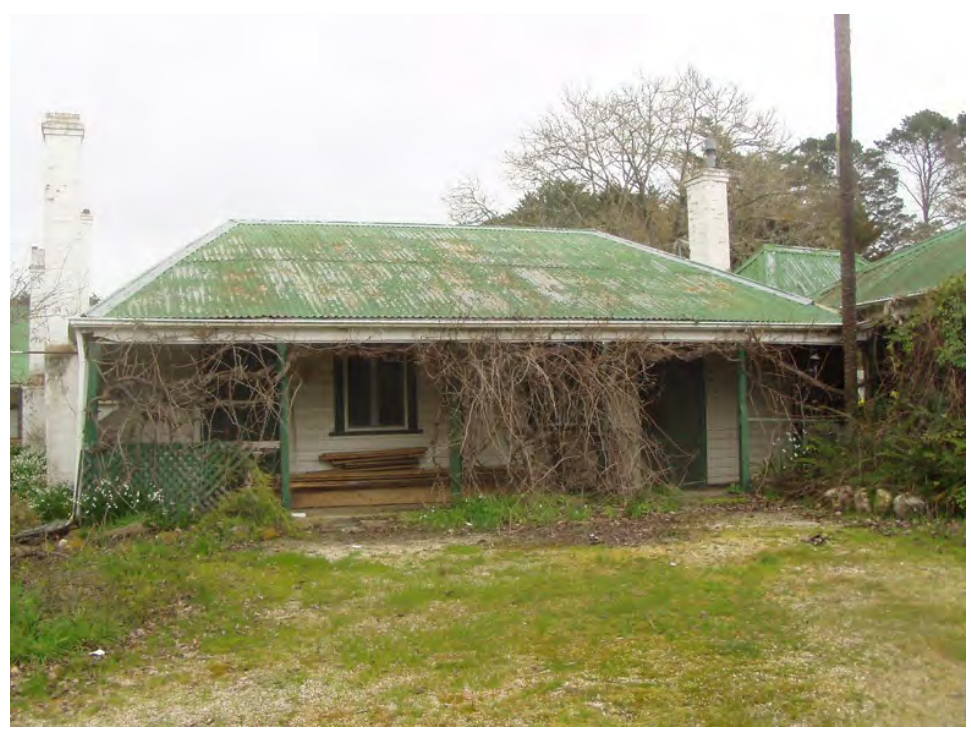

\section{Illustration 8. Trawalla homestead.}

Source: Barbara Dawson, August 2004.

Assuming the privileged position of whiteness, the Kirklands exerted their colonial authority over the Wathaurong. They tried to 'turn away' the Aborigines, allowing (and encouraging) only 'Tom' to remain overnight, as the Kirklands hoped that this 'big boy' would be 'useful in finding stray animals'. They were to be disappointed. Not able or willing to comply with the Kirklands' Protestant work ethic, Tom was thought to be 'very lazy, but he was always obliged to chop wood or do some work, else he got nothing to eat; which we found to be the only way to make the natives active'.$^{37}$

Implicit evidence that the Aborigines resisted the attempted banishment from country is found in Katherine's observations of Indigenous family life, seen at close range. She wrote that:

Vol. II: 192; Bailliere's Victorian Gazetteer and Road Guide Containing the Most Recent and Accurate Information as to Every Place in the Colony, Compiled by Robt P Whitworth, F F Bailliere, Melbourne, 1865: 386; Personal communication from Fiona Mackenzie, Trawalla homestead, August 2004.

36 Billis and Kenyon 1974 [1932]: 292. The original holding of 40,000 acres is an estimated area, Spreadborough and Anderson 1983: 139. Fiona Mackenzie, occupier of Trawalla in 2004, cited the property as 42,000 acres.

37 Kirkland, Life in the Bush, c. 1995: 23, 17-18, 19. 
In the evening they meet at their mi mi; the men eat first, and whatever they choose to leave, the leubras and pickaninnies may eat afterward. Sometimes a very affectionate cooley may now and then, while he is eating, throw a bit to his leubra, as we should do to a dog, for which kindness she is very grateful. ${ }^{38}$

She also witnessed that:

The natives will eat anything that comes in their way. I saw a woman take a piece of sheep-skin, singe the wool off, and then begin to eat it, giving her baby a piece of it also. Much to my surprise, they actually ate a large piece of the skin. ${ }^{39}$

The continued presence of the Moner balug at Trawalla is perhaps best demonstrated in the reaction of three-year-old Agnes to the arrival of a white lady at Trawalla, about one year after the Kirklands' settlement. While Katherine was 'delighted to have the privilege of talking to a lady again', Agnes described the woman as a 'white leubra' and asked persistently whether there were 'any more like her in the country' ${ }^{40}$

\section{Interracial female friendship?}

This anecdote featuring Agnes highlighted Katherine's isolation from other women. While male networks were maintained through farm employees, and constant visits from neighbouring squatters or itinerant workers and travellers, women settlers were left unsustained and, to a large extent, uninitiated into the foreign land. As farms were taken up in the Western District no closer than five kilometres from another ${ }^{41}$ (and separated by often boggy roads), white women were geographically separated from each other, meeting only when travelling between the larger settlements of Melbourne and Geelong and their isolated outposts. During Katherine's two years' residence at Trawalla, her contact with white women of her own class - a factor that discounted Mary Forrester's presence-occurred on only two occasions. After the birth of her son in September 1839, Katherine stayed in Melbourne for two months. Celia Scott accompanied her on her way home, as far as the Scotts' property, (now) Boninyong, 15 kilometres south-east of Ballarat. Katharine had just acquired a

\footnotetext{
38 Kirkland, Life in the Bush, c. 1995: 14 (italics in original).

39 Kirkland, Life in the Bush, c. 1995: 20.

40 Kirkland, Life in the Bush, c. 1995: 21.

41 'Thomas Learmonth, writing from Buninyong in 1853, recalls that there was 'a tacit understanding that no one was to take up a station nearer than three miles to another person', Croll 1937: 30.
} 
new neighbour, but she was 50 kilometres away. ${ }^{42}$ The other instance, referred to above, was when Mrs Gibson visited on her way to establish a farm with her brother further inland. ${ }^{43}$

Early in her commentary, Katherine voiced her abhorrence of the settlers' staple diet of 'nothing but mutton, [black] tea, and damper three times a-day', every day. Before she could establish her vegetable garden, dairy, poultry yard and piggery, Katherine had to find a way to feed her husband, young daughter, her 21-year-old brother, James, and the fellow Scots, Mary and Sandy Forrester. There were also about four other men on Trawalla, working as labourers or shepherds. Travellers might unexpectedly call in, but all expecting to be fed. Nourishment was vital to Katherine, who arrived at Trawalla in the early months of pregnancy, and left when her son was less than 18 months old. She had lost the services of her maid, who was likely to have had at least basic cooking skills, when this servant chose to remain in Hobart. Katherine was soon to learn that Mary Forrester was 'very ignorant in cooking'. ${ }^{44}$

Katherine's geographical isolation entailed separation from female sources that may have helped her maintain the healthy survival of herself and her family during the first months of settlement. She could not gain from white women, however, the kind of information she most needed: about types and sources of local bush tucker as it applied specifically to the regional landforms, waterways and vegetation of Trawalla. Only Moner balug women held this knowledge. Hints in the narrative point to their vital and generous assistance.

Katherine had noted, for example how the Moner balug women dived into the fresh-water ponds for mussels. She also knew that they were,

fond of a large grub found generally in the cherry and honeysuckle tree: they can tell, by knocking the tree with a stick, if any grubs are in it. When they knock the tree, they put their ear close to listen, and they open it with a tomahawk at the very spot the grubs are to be found. ${ }^{45}$

Swapping recipes underlies many female friendships. While settlers could trade a piece of dress or a red pocket-handkerchief - which the Aborigines liked

\footnotetext{
42 Andrew and Celia Scott arrived at Port Phillip in January 1839. They settled on 16,000 acres at Mount Buninyong after searching for suitable land to the west and north of Ballarat, Henderson 1936: 212-213; Celia Scott was 'the first and for some time the only white women in the Buninyong locality', Billis and Kenyon 1974 [1930]: 122.

43 Mrs Gibson's 'brother' was most likely her husband, Matthew Gibson, who held land at Kenilworth on the Wannon River (1840-41) and on 'Roseneath', on the Glenelg River (1840-43). At Roseneath, Mrs Gibson lived in a tent for 10 months 'on the verge of the wilderness', Bride 1983 [1898]: 299, note 18; 170, note $10 ; 161$.

44 Kirkland, Life in the Bush, c. 1995: 9.

45 Kirkland, Life in the Bush, c. 1995: 19-20.
} 
to tie round their necks - for Indigenous possum pelts and flying-fox skins, Katherine's need for Indigenous 'recipes' from Indigenous women's knowledge of food supplies and preparation was a one-way process.

Katherine divulged Indigenous help indirectly. Without explaining how she knew such details, she informed her readers that the Aboriginal women dug up with long, pointed sticks, their staple food, maranong, from which the Moner balug derived their name. ${ }^{46}$ Katherine had been pleased to use this white root for soup, describing it as 'shaped like a carrot, but the taste is more like a turnip'. She had also tasted 'manna' which fell from eucalypts, identifying it as tasting like almond biscuits. Precise understanding that manna was available only at certain seasons of the year and could be gathered only before sunrise before it disappeared soon afterwards implies interracial 'conversations' in which the Moner balug explained, pointed out and took Katherine along with them to food sites at appropriate times for gathering.

Although declaring on her arrival at Trawalla that, 'I did not know much of cooking myself', Katherine later displayed her enthusiasm for the culinary arts, exemplifying her philosophy that 'necessity makes one learn many things'. Vegetarian cookery became her speciality. She was later to publish Vegetarian Cookery, the sixth edition of which appeared in the 1860s. Along with vegetarian recipes for soups, pies, cakes and preserves, the book includes a 30page introductory scientific treatise evaluating the nutritional benefits gained from a vegetable diet as a natural source of 'the proper Food of Man' ${ }^{47}$ Surely the Moner balug women had helped in this conversion.

Competent and industrious, Katherine established, within 18 months of pastoral settlement, a vegetable and fruit garden of potatoes, peas, gooseberries, raspberries, strawberries and currants. Except for the milking of her 20 cows, she managed her dairy single-handedly, producing butter and cheese that, together with her poultry, she sold on the Melbourne market. Her skills in economic management encompassed an astute knowledge of the fluctuating Melbourne market prices for food and other commodities.

\footnotetext{
46 Kirkland, Life in the Bush, c. 1995: 19, 14. Murrn'yong was originally classified as Microseris fosteri. It is now known as Microseris scapigera in Victoria and Microseris lanceolata in New South Wales. Other botanical names have been used in the past. B Gott has written widely on this staple indigenous food. Cf., for example, Gott 1983: 2-18. Michael Christie also identifies 'mirr-n'yong', or yam, as the Wathaurongs' staple food, Christie 1979: 9; Clark 2003: 113, 133, 345.

47 Kirkland, Life in the Bush, c. 1995: 9; Katherine Kirkland, Vegetarian Cookery, By a Lady, With an Introduction Explanatory of the Principles of Vegetarianism By the Late Jas Simpson Esq., The Sixth Edition, Fred. Pitman, London, 186?.
} 


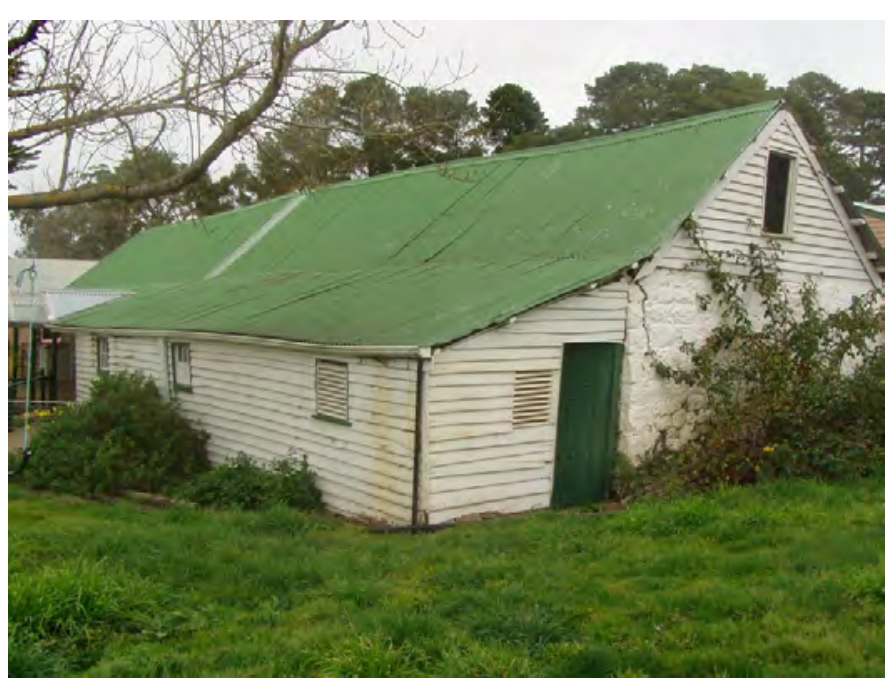

Illustration 9. Katherine Kirkland's dairy.

Source: Barbara Dawson, August 2004.

In order to show her readers 'what good things we had in the bush', Katherine unashamedly revealed her 1841 New Year's Day dinner menu that incorporated Indigenous food into traditional British fare:

We had kangaroo-soup, roasted [wild] turkey well stuffed, a boiled leg of mutton, a parrot-pie, potatoes, and green peas; next, a plum pudding and strawberry-tart, with plenty of cream ... [and, later] currant-bun, and a large bowl of curds and cream. ${ }^{48}$

Another indication of a physical closeness between Katherine and the Indigenous women was Katherine's adoption of Indigenous methods of infant care. Mary Forrester restricted her chores to washing or cooking (and never both together) and refused to help tend the children. Katherine therefore worked alone in her dairy and, if her baby was not asleep, copied the way the Aboriginal women carried their babies, so that her hands were free: 'I put him in a basket', she told her readers, 'and hung him at my side, as I had seen the native women $\mathrm{do}^{\prime} .{ }^{49}$ She had also drawn close enough to the Moner balug to observe that:

The women carry their children at their backs in a basket or bag; and when they suckle them, they generally put their breast under their arm; and I have seen them put it over their shoulder. ${ }^{50}$ 
Perhaps it was an indication of a form of female friendship that Katherine sympathised with Indigenous concerns about dwindling water sources. By reiterating the Aborigines' complaints partly in their own dialect, she revealed direct cross-cultural communication through shared dialogue, writing that:

Many lakes, both salt and fresh, have dried up lately. The natives say it is the white people coming that drives away the water: they say, "Plenty mobeek long time, combarley white fellow mobeek gigot - in English, "Plenty water for a long time, but when the white people come, the water goes away." ${ }^{51}$

Katherine also told her readers that she very much liked the 'native names' for rivers and landforms, declaring that, 'I think it a great pity to change them for English ones, as is often done'. She also incorporated Indigenous terminology in her text, using for example 'tuan' to denote 'the flying squirrel', although including both terms on behalf of her British readers. ${ }^{52}$

\section{Violence on the frontier}

The Western District, in the years of Katherine's residence, has become known in historical terms as arguably 'one of the two worst areas of racial violence' in New South Wales, during the late 1830s and early 1840s. ${ }^{53}$ This was another area in which Katherine tried to maintain a textual 'silence'.

One of the first comments she chose to write down about her arrival at Point Henry was her fear of the Aborigines. She wrote:

I kept looking round, expecting every moment to see some of the dreaded savages rushing upon us. I did not feel comfortable on account of the natives, I had heard such accounts of them in Van Diemen's Land. ${ }^{54}$

Mary Forrester was similarly affected. At Geelong,

She would scarcely move out of the hut, and was always crying and wishing herself at home. She said she was determined to make her husband send her home with the first money he made. She wondered

\footnotetext{
51 Kirkland, Life in the Bush, c. 1995: 8. A drought between 1837 and 1842 had precipitated water shortages, exacerbated by inroads of stock animals and the white man's injudicious use of precious water resources including the Bolac and Keilambete Lakes, oral communication from Roger Jones, CSIRO, Aspindale, Victoria. From 1839 to 1841, Lake Burrumbeet was completely dry, Anderson 1969: 182, note 8.

52 Kirkland, Life in the Bush, c. 1995: 27, 20.

53 Critchett 2003: 52. The other main area of conflict is cited as the Liverpool Plains, north of Sydney. Although Critchett refers to the Portland Bay District of Port Phillip, this area roughly corresponds to the present Western District of Victoria.

54 Kirkland, Life in the Bush, c. 1995: 3.
} 
why I did not think as she did. She would take comfort from no one, and was quite sure she would be killed by the wild natives when she got up the country. ${ }^{55}$

By the time the Scots had reached Trawalla, Mary was apparently no longer afraid of the Aborigines and Katherine's tone and term of reference signified a return to reason on the part of her servant.

The editor of the Geelong Advertiser, however, summed up the prevailing situation in December 1840:

The interests of the blacks and whites are directly at variance ... It is nonsense to say to the settlers, "Be kind to the poor blacks, we have injured them," and such-like stuff. You might as well put a dozen cats into a room full of rats, and then tell them not to fight. You make them enemies and then wish them to be friends.

The aborigines require the unrestrained liberty of traversing the whole of their ancient possessions; while the settlers claim the undivided occupation of the richest tracts ... civilisation destroys the hunting fields of the aborigines. How, then, can they ever agree? Neither of them will change their dispositions or interests; they cross each other at every point. Continual animosities and outrages ensue; and hatred and revenge are engendered on both sides. ${ }^{56}$

Not only Yuille but also the other Scots that accompanied the Kirklands on their 130 kilometre trip inland had 'either pistols at their sides or a gun in their hands', ${ }^{57}$ evidence of their preparedness for the worst.

In 1837, settler fear of Aboriginal 'attack' had initiated requests for protection, and resulted in Governor Bourke's appointment of Captain Foster Fyans (previously the commandant at Moreton Bay, at the time of Eliza Fraser's 'rescue') as Police Magistrate at Geelong. The number of Fyans' support staff-consisting of a clerk of courts, three constables and 12 convicts - indicates the extent of alarm. ${ }^{58}$ Also indicative of insecure race relations was the formation in London in 1836 of the Aborigines Protection Society, formed to lobby for legislative protection for Aborigines. Consequent to this action, the Port Phillip Aboriginal Protectorate was created by the Colonial Office in January $1838 .{ }^{59}$

55 Kirkland, Life in the Bush, c. 1995: 4.

56 Geelong Advertiser, 12 December 1840: 2.

57 Kirkland, Life in the Bush, c. 1995: 3.

58 Robinson and York 1977: 30, 36.

59 Abandoned by 1850, the scheme, not only to protect but also to 'assimilate, convert and civilise' the Aborigines of Port Phillip, was deemed to have been largely a failure, Shaw 1996: 143; Clark 1995: 3. 
George Russell recorded that, until 1838, most settlers chose to remain close to Geelong and Melbourne 'for security against the outrages of the natives'. From 1837 to 1839, Trawalla was at the frontier of black-white collision. Robert Hamilton noted that, a few months before Katherine's arrival, 'The natives were pretty numerous ... and did not seem too pleased' when William and Ardey Yuille, and Henry Anderson, attempted to settle a little south of Trawalla. A large grass fire, apparently lit by the Aborigines, frightened them and they withdrew with their sheep. Hamilton also reported the 'troublesome' behaviour of the Wathaurong, as the 'mounted and armed' settlers travelled through their country. The results were what Michael Cannon has called the 'bloody confrontations' of the early 1840s. ${ }^{60}$

Katherine refers indirectly to instances of racial violence. Her commentary includes her feelings of horror whenever she passed through the 'Murderer's Valley' (where a shepherd had been killed by Aborigines before the Kirklands' arrival). In relation to her own residence at Trawalla, she wrote enigmatically of 'the occasional frights ... from natives, with whom it was no easy matter to be on good terms', before turning to the safer topic of troublesome dingoes. When she chose to elaborate on one of these 'frights', she emphasised the elements of danger and excitement that might appeal to a voyeuristic British readership's interest in nude savages and solitary women and children on an isolated colonial frontier. She wrote that, when she and Mary were alone with the children,

We [saw] seven wild natives run past our hut at a little distance, all naked, which gave us a great fright; I thought Mary was going into a fit. I got my pistol which I had hanging in my room, loaded; Mary then went for hers, and we walked up and down before the hut for about an hour. ${ }^{61}$

The women's ready recourse to weapons reveals the ever-present threat of violence, with or without actual conflict. Although quiet on the reason, Katherine also chose to confide that 'old settlers would give an enormous price for good fire-arms'. She nevertheless strove to represent both sides of the

60 Brown (ed.), Narrative of George Russell of Golf Hill with Russellania and Selected Papers, Oxford University Press, London, 1935: 161; Kirkland, Life in the Bush, c. 1995: 34, 38; Hagger, 'Kirkland, Katherine', at www.adb.anu.edu.au; Cannon 1990: 85.

61 Kirkland, Life in the Bush, c. 1995: 18. Katherine's show of force replicates other accounts from outback locations where female colonists, in anticipation of trouble, brandished their firearms and paraded outside their huts, dressed as men. Cf. Ann King, The Richmond River Experiences of Ann King: Later on Mrs T.N. Hollingworth, and now Mrs H. Dawe, believed to be the oldest resident of the Richmond River, D S Ford, Sydney, 1929, reprinted from first edition, the Northern Star, Lismore, 1918: 2 (unpaginated). Other narratives that refer to women's ready access to guns are Mrs Abraham Wallace (Matilda Hill), Twelve Years' Life in Australia: From 1859 to 1871, ?South Australia, n.d., (p. 13); and Mary McMaugh, Pioneering on the Upper Macleay. Peeps into the Past: The Days of Yore, Chronicle Print, Wingham, NSW, 192? (p. 6). 
frontier in her comment that: 'In many instances the undue severities of the settlers lead to reprisals from the natives, who were apt to inflict vengeance in a very indiscriminate manner' ${ }^{62}$

In The Black Resistance, Fergus Robinson and Barry York concluded that 'by 1845 the Wathaurong had suffered a devastating decimation of their numbers - a decline of more than fifty per cent - as a result of the British colonial aggression'. Thomas Browne, who later wrote under the pseudonym, 'Rolf Boldrewood', and who drove cattle in 1842 from Melbourne to Port Fairy, south-west of Trawalla, referred to 'wrong-doing and violence, of maimed and slaughtered stock, of homicide and murder.$^{63}$ Whilst encompassing other causes, violence is included in George Augustus Robinson's 1839 list of 'the evils accruing to the Aborigines by occupancy of their lands by the whites', namely, 'Disease of fatal character, hunger and distress, murder and rapine' ${ }^{64}$

While reports from early settlers had estimated the Aboriginal population to be between 3,000 and 7,500 for the present State of Victoria, when the first official count was taken by the Board for the Protection of Aborigines in 1877, only 774 'natives of pure descent' had survived or, when including part-Indigenous people, 1,067. Correspondents to Bride's Letters from Victorian Pioneers affirmed that by the early 1840s, the numbers of Aborigines had been very severely reduced and that by 1853 few remained on the pastoral lands of the Western District. According to G A Robinson, the Moner balug were 'defunct' by $1841 .{ }^{65}$

A prime cause of white aggression was the stealing by Aborigines of stores and animals, or the spearing of livestock. Niel Black, a squatter on Glenormiston station, near present-day Terang, south of Trawalla, wrote that most settlers considered bullets to be the surest deterrent against sheep stealing. ${ }^{66}$ While Katherine maintained narrative silence on aggressive action against the Moner balug at Trawalla, pictorial evidence points to her knowledge of violence. Her sketch on the title page of 'Life in the Bush' in Chambers's Miscellany, 1845, depicts in the foreground at Trawalla an armed settler aiming a rifle at a retreating Indigenous family group. One of the Aboriginal men turns towards the two settlers, spear poised for throwing. It seems unlikely that the publisher

\footnotetext{
62 Kirkland, Life in the Bush, c. 1995: 11, 20-21.

63 Robinson and York 1977: 37; Thomas Browne had arrived with his family in Melbourne in 1840, aged 14. From 1844 to 1858 he ran the property, Squattlesea Mere in the Portland area, Rolf Boldrewood, Old Melbourne Memories, William Heinemann Ltd, Melbourne, 1969 [1884]: 54-55, xii.

64 Ian D Clark (ed.), The Journals of George Augustus Robinson, Chief Protector, Port Phillip Aboriginal Protectorate, Volume One: 1 January 1839 - 30 September 1840, Second Edition, Heritage Matters, Ballarat, Victoria, 2000, 21 April 1839: 31. For a full discussion of the historical debate into the causes of the decrease in Indigenous populations cf. Dawson 2007.

65 Aboriginals in Victoria, c. 1976: 3. Statistics from the first detailed Victorian census in Victorian Legislative Assembly, Votes and Proceedings, 1877-78, Vol. III, 'Fourteenth Report', Appendix X, p. 12, cited in Reece 1974: 16; Roberts 1964: 329; Bride 1983 [1898]: 320-321; Clark 2003: 197.

66 Christie 1979: 40.
} 
is deploying a cliché because the same drawing forms part of an illustrated map of the Kirklands' 1838 sea voyage to Australia, reproduced in the entry of Katherine's family, 'Hamilton of Polkemnet', in Henderson's Australian Families, ${ }^{67}$ where Katherine's drawing illustrates a larger picture entitled, 'Course of the barque "Renown" from Greenock to Hobart Town, V.D.L, 1838'. In 'Life in the Bush', mountains have been sketched as background, perhaps as a form of graphic appeal for Scottish readers. In Mackenzie's 1995 edition of Life in the Bush, the threatening foreground figures have been erased from the image on the title page. Although this sort of evidence is difficult to interpret, the details of slab huts, rooflines, fences and farm equipment suggest that the image is not merely conventional, but particular to Trawalla.

Violence at Trawalla is supported by anecdotal evidence attributed to Robert Hamilton, who is said to have told his grandchildren that, 'Because of his brother-in-law's treatment of aboriginals, he feared that his sister was exposed to danger' ${ }^{68}$ The dilemma of interpreting undocumented evidence is presented by the sight of round holes in the slab walls of an original outbuilding adjacent to Trawalla homestead. Do they silently attest to frontier conflict? Not large enough to sight a gun, were they auger holes made big enough for a gun barrel? On the other hand, if they are gun or bullet holes, the question remains as to which historical time they apply, and to what purpose.

Katherine is silent on the role that violence played both prior to and possibly during her residence. While naturally reticent to implicate her menfolk in attacks on Aborigines, she chose to convert a potentially violent episode involving sheep stealing to an example of Aboriginal skill and ingenuity. Her account of the theft of sheep from Trawalla presents a confusing message. She omitted any reference to retaliatory action and highlighted Indigenous expertise.

Some time in 1840 and (as Katherine is perhaps careful to observe) when Kirkland was 'at the settlement', 92 sheep went missing. James Hamilton, Trawalla workers and neighbouring landholders went in pursuit of them, Katherine reporting that:

At last, after fourteen days' riding, the sheep were found a hundred and forty miles [225 kilometres] from our station. My brother and his friends had almost given up thoughts of looking any longer for them; but they rode on about a mile farther, when they saw them in a hollow, surrounded by about a hundred natives. The men all hid themselves, having seen the party coming, and left the women and children, who ran about chattering, and hiding behind the rocks. The party rode down among them, and a singular scene met their view. The ground

67 Henderson 1941: 339.

68 Anderson 1969: 16. 
was strewed with heads of sheep and bits of mutton, and some of the sheep were as well cut up as if done by an English butcher; the skins were pegged out on the ground, and the fat collected in little twine bags, which the women make of the bark of a tree. Fifty live sheep were enclosed within a brush fence (James said it was the best brush fence he had seen in the country), but they were very thin, the natives being too lazy to take them out to feed. They were killing and eating them up as fast as they could. ${ }^{69}$

The fact that the white men took away with them the spoils of the raid (spears, tomahawks, waddies, and baskets) points to an uneasy undercurrent of unrevealed strife. What Katherine chose to highlight of the return trip, however, was the agility of the young Aboriginal tracker:

The native boy mounted a horse, saying he would not walk a step; but as he mounted he slipped off again, and the horse started on; the little fellow caught hold of the tail, and allowed himself to be dragged on till he got a good firm hold, and then sprung on the horse's back. James said he never saw a cleverer piece of agility in a circus. ${ }^{70}$

Whether Katherine reiterated these accounts as told to her by Hamilton and was ignorant of possible violent elements in the encounter, or whether a narrative decision of omission and addition was entirely her own, her account joins the genre of what Tom Griffiths has referred to as 'veiled' reports of frontier life. ${ }^{71}$

\section{Moner balug authority}

Because Katherine's text was published in the period before Aborigines had established a position in colonial station life, it pinpoints a time when the emerging dichotomy of 'wild blacks' (as in her story of the 'wild natives ... all naked') and 'station Aborigines' was still being played out at Trawalla. Charlotte Fisher's term of 'civilised natives', at Geelong in 1839, demonstrates an early step towards this resolution. Katherine's narrative encapsulates the confusion in a changing social climate.

Although the Kirklands had tried to remove the Moner balug from their land around the homestead, the Aborigines continued to return and to camp at the site for longer periods. Proximity to the Kirklands can be judged — as well as by

69 Kirkland, Life in the Bush, c. 1995: 17. Did Katherine inflate Indigenous ingenuity? Colin Campbell who, with his brother Alexander, Sandy Forrester and the Indigenous boy, Charley, joined the pursuit, wrote that the sheep were found on the afternoon of the second day, Anderson 1969: 16-17.

70 Kirkland, Life in the Bush, c. 1995: 17-18.

71 Cf. Griffiths 1996: 106-109, 113-115. 
the references to Indigenous women - by the fact that an Aboriginal lad seemed to be on hand to help track the stolen sheep. This 'little fellow' seems not to be 'Tom' (the only Moner balug individualised by Katherine) because Tom was described as 'big'. The Aborigines initially reacted to white coercion that would ultimately dissipate and dissolve their cultural and social identity, by ignoring the Kirklands' commands.

Throughout her text, Katherine projected herself as a genteel British lady of good taste and character, and one who appreciated and respected civilised standards despite her remote colonial location. Her perception of what was respectable focused on the privacy of her home. The spaces within were sacrosanct. While Aborigines could draw close in a dilapidated wayside hut, they were excluded from her own domicile. That cultural boundary was not to be crossed, and she expressed disapproval that a neighbouring (male) settler allowed it.

Although residing in a slab hut, with one-inch gaps between the wooden boards that made up the walls, and initially without doors or windows, she had furnished her home with the refinements of Scottish gentility. One of the three rooms of her home was set aside as a 'sitting room', with family portraits decorating the walls.

In a story that supports Henry Reynolds' theory of the interplay of resistance and attraction at the frontier, ${ }^{72}$ some Aboriginal men from a group of about 100 at the homestead entered Katherine's house when she was alone. They were amused at what they saw, but Katherine was not:

[the Aborigines] examined all they saw very attentively, especially the pictures we had hanging on the walls. They were much taken with a likeness of my mother and laughed heartily at some black profiles; they said they were "black leubras." I told them to leave the hut, but they would not; and one, a very tall fellow, took the liberty of sitting down beside me on the sofa. I did not much like being alone with these gentry, so I rose to go to the door to call some one, but my tall friend took hold of my arm and made me sit down again; on which I cried out sufficiently loud to alarm my husband, who was building a hut behind. He came in and turned them out. ${ }^{73}$

This show of male Aboriginal authority (and confidence in the absence of the white men) was to be curbed by the white man's gun. British racial superiority was, in this case, backed by the threat of violence. Because the Moner balug 'still kept hanging about the station', Kirkland had taken his gun and shot

72 Reynolds 1990: 128.

73 Kirkland, Life in the Bush, c. 1995: 20. 
some cockatoos flying overhead. Katherine's literary resolution of a potentially conflictive situation was to return to the safe subject of food. She elaborated on this theme, recalling that:

Some of the natives ran and picked them up, and thrust them into some hot ashes, where they had lighted a fire, without even taking the feathers off. They were soon cooked in this way, and I believe ate very well. ${ }^{74}$

\section{Return to Britain}

The Kirklands' foray into pastoral pursuits coincided with a growing economic depression and drought. Leaving the farm to James Hamilton, ${ }^{75}$ the Kirklands moved to a 40-acre agricultural farm on the Darebin Creek, north-west of Melbourne. They moved again soon afterwards when Katherine developed a severe bronchial complaint following her efforts to control a firebreak around their tents during a bushfire. On 19 July 1841, she opened a short-lived 'Seminary for young ladies ... for a few boarders and a limited number of day scholars' in Melbourne, before closing it because of ill-health. Kirkland served as registrar of the Court of Requests for six months, and as a clerk of the Magistrates' Bench. On 7 September 1841 Katherine and her children sailed for Britain aboard the barque, Brilliant. In July 1842, Kirkland was declared insolvent and forced to sell his colonial estate. His friends raised money for his passage to Scotland where he returned in 1842, broken physically and financially. ${ }^{76}$

Katherine turned to one of the few remunerated activities open to middle-class women in nineteenth-century Britain, particularly if they remained anonymous. A connection by marriage to the Chambers brothers may have smoothed Katherine's path to publication: Kenneth Kirkland's cousin, James Muir Dowie, had married Annie Chambers, the daughter of Robert Chambers. Or Robert's interest in evolutionary theory may have opened doors to Katherine's narrative because it dealt with Aborigines. ${ }^{77}$

\footnotetext{
74 Kirkland, Life in the Bush, c. 1995: 20.

75 Kirkland, Life in the Bush, c. 1995: 24. Cf. 'Bulgana', 'First Days of Trawalla: A Scottish Invasion', in the Australasian, 28 November 1931: 4 - a 'certain incompatibility of temperament led to a separation'. Trawalla was sold by James Hamilton and H B Hassell to Adolphus Goldsmith in 1841, Anderson 1969: 20.

76 Hagger, 'Kirkland, Katherine', at www.adb.anu.edu.au; Port Phillip Gazette, 21 July 1841: 1; Brown 1958: 82; Port Phillip Herald, 12 November 1841: 3.

77 In 1844, Robert Chambers had published anonymously the evolutionary treatise, Vestiges of the Natural History of Creation, W Chambers, Story of A Long and Busy Life, W \& R Chambers, Edinburgh and London, 1882: 93; Griffiths 1996: 44.
} 
5. An Early, Short-term Settler-Katherine Kirkland: Valuable Insights Through the Silences

\section{Conclusion}

Life in the Bush is a pivotal text in the history and historiography of interracial frontier relationships. In the hinterland of Port Phillip during the early 1840s, colonists and Aborigines alike were sorting out their roles and position in the emerging settler society. Katherine's reference to both 'wild' Aborigines and to the family groups who gravitated back to the Trawalla homestead site in a peaceful move to coexistence reflects this as yet unresolved relationship. Written in a period of historical transition, Katherine has captured Indigenous culture, before its integrity was destroyed and reassessed through the eyes of the conquering white man.

Katherine seemed to be caught between the pull to reiterate the British preconceptions and stereotypes of colonial scenes and of the Indigenous inhabitants as strange and wild, and a realisation when she lived amongst the Moner balug at Trawalla that these assumptions were misplaced. This tension infiltrates a text that both pays homage to British middle-class values while also displaying a need to fairly represent the Aboriginal people. As the period of writing corresponded with rising imperial confidence, Australian colonists were apt to express their racial superiority without reservation. A J Campbell, minister of St George's Presbyterian Church, Geelong, wrote in 1862 that the white man had a God-given right to cultivate the earth and to graze animals because, 'If the aborigines make no use either of the grass-covered surface or of the fertile soil, I think we are ... entitled to put our sheep on one, and our ploughs into the other'. In acknowledging that Aborigines had been 'poisoned, shot down, demoralized, and slain by drink and loathsome disease', Campbell accepted as inevitable that 'the white man's progress involves the black man's disappearance' ${ }^{78}$ Katherine complied with the process of settlement as a member of the perceived superior race and as a supportive wife. She therefore reflected British attitudes, while sometimes qualifying and questioning them. Her narrative voice moves from fear and ignorance to guarded appreciation, which included sympathy with Indigenous reaction to settler incursion.

As a trailblazer in the historiography of friendship between Indigenous and white women on Australia's raw frontier, Katherine, unable to foresee her readers' acceptance, would have been uncertain about how to represent interracial communication that involved Indigenous female help. On one level, she viewed Aborigines from the perspective of a respectable middle-class British lady - a persona that she was bound to perpetrate for her authorial image. On another level, the text hints at a closer interracial relationship than the author

78 'A J C of Geelong', The Free Church of Scotland Monthly Record, 1 December 1862, cited in Griffin 1993: $83-85$. 
is prepared to divulge. Katherine masks these parts of her story by resorting to generalisations or remaining silent on crucial details. She further displayed her confusion by, on the one hand, reiterating the racial stereotypes of Aboriginal ugliness, laziness and violence and, on the other, revealing an empathy with Indigenous culture and concerns.

Katherine represents the difficulty of white, female colonial writers, who know about male interracial conflict but who have experienced a tentative (or fuller) friendship with black women. She slanted her interpretative message of frontier violence by referring to it in general terms that did not specify the activities of her own family. Although she lived in a climate of racial violence, (actual clashes and the threat of attack), her silence on the subject supports Tom Griffiths' observation that, on (and of) the frontier, 'murder could not be openly discussed'. Furthermore, her omissions demonstrate that the 'shifts in interpretation' that Chilla Bulbeck attached to the part played by memory in secondary reports of the frontier (as found in 'books ... docu-drama, national celebrations and monuments') could similarly apply to a primary source. ${ }^{79}$

While choosing to hide an emerging relationship with Indigenous women and to suppress explicit details of frontier conflict, Katherine presented a vivid picture of Wathaurong confidence, honour and firm identity in her portrayal of their traditional welcoming ceremony. The dramatic power of the corroboree revealed the strength of Indigenous territorial authority in those early days of white settlement, before the imminent demise of Aboriginal social and cultural cohesion. By depicting their pride of land ownership in 1839 and 1840, Katherine's text has captured the last years of pre-colonial Indigenous huntergatherer society.

Katherine Kirkland's commentary from 1842 remains trapped within a larger story waiting to be told. As a forerunner in the genre of black-white frontier relationships, this early colonial text laid a foundation for the interpretation of the accounts of other women from different inland locations and of different times. The women in the following chapters inhabit ground (geographically and culturally) on which the events of colonisation have determined that a different type of interracial relationship has evolved. The works of Mary McConnel and Rose Scott Cowen have moved on and beyond the veiled references of Life in the Bush to present a 'clearer' picture of interracial relationship, albeit from their own points of view. Within these discourses, Indigenous strengths of character again emerge. 


\section{Mary McConnel: Christianising the Aborigines?}

All this "yarmen" (land) belonging to me'. ${ }^{1}$

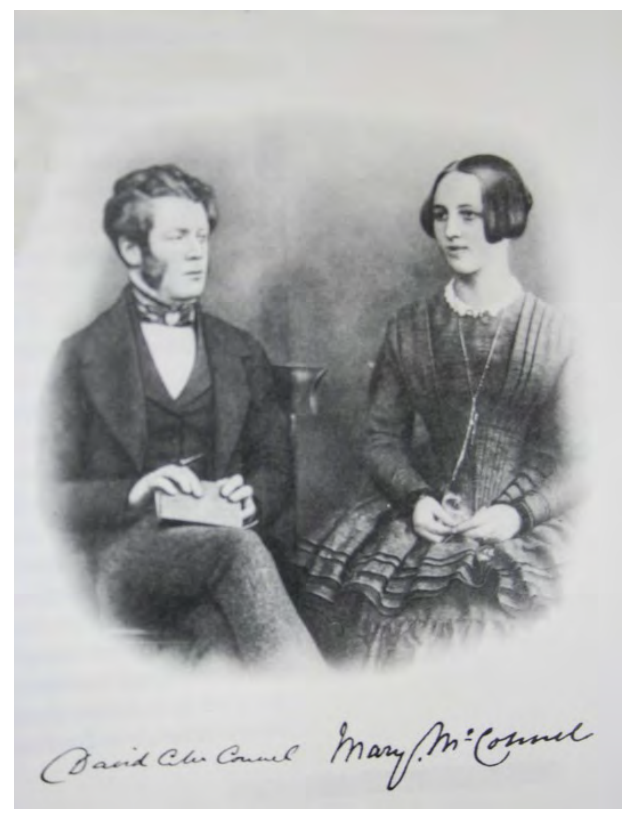

Illustration 10. David and Mary McConnel.

Source: Mary McConnel, Memories of Days long gone by, By the Wife of an Australian Pioneer, M McConnel, Brisbane?, 1905.

\footnotetext{
1 Mary McConnel, Memories of Days long gone by, By the Wife of an Australian Pioneer, M McConnel, Brisbane?, 1905: 43. The date of publication is tentative. The ML copy has inscription by author, dated March 1909, 'David Cannon McConnel Biographical File', ANU Archives. An alternative title on the spine is 'Queensland Reminiscences 1848-1870'.
} 


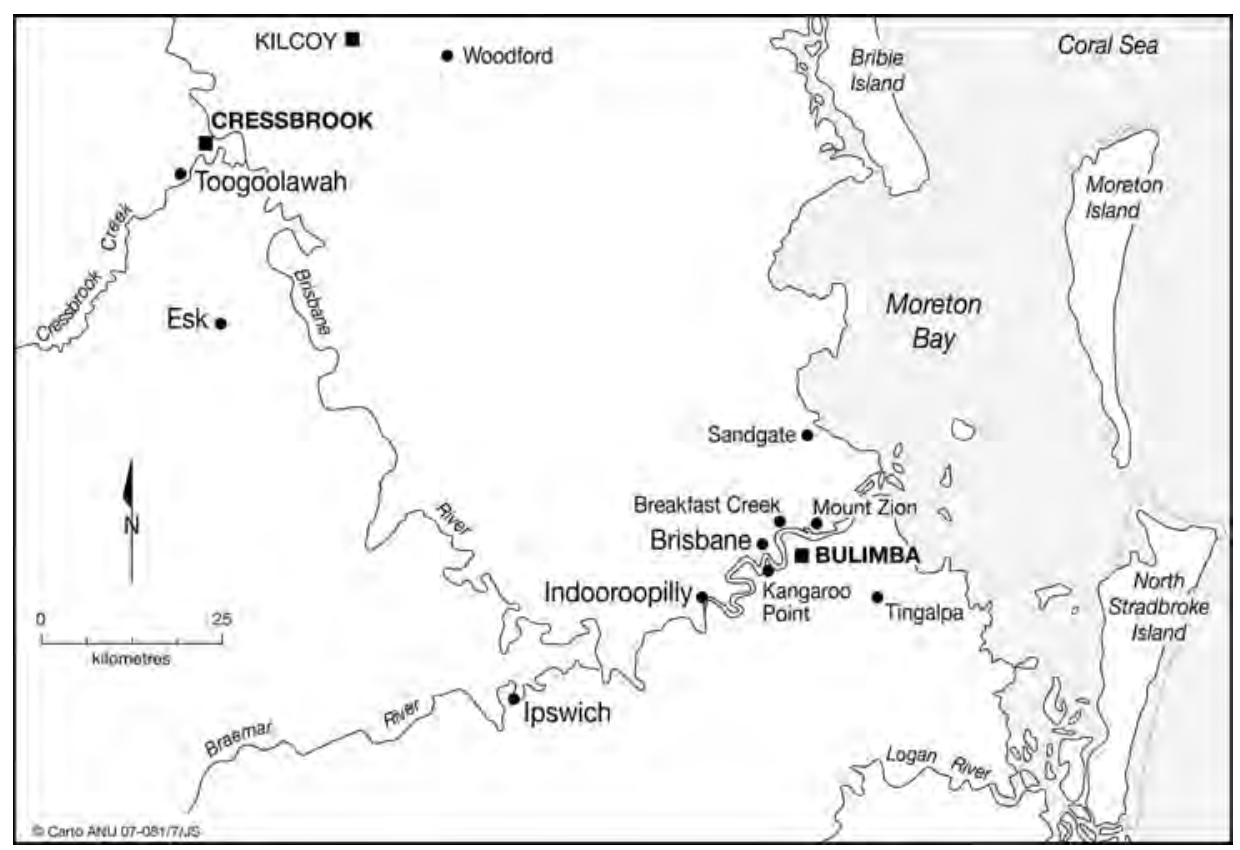

Map 6. Mary McConnel. South-east Queensland including Moreton Bay, Brisbane and the Brisbane River district.

Source: CartoGIS, College of Asia and the Pacific, ANU.

Mary McConnel lived among the local Indigenous peoples on two properties: on her husband's sheep and cattle property, Cressbrook, near Toogoolawah, ${ }^{2}$ 25 kilometres north of Esk and 200 kilometres north-west of Brisbane and, from 1849 to 1853 at their agricultural farm, Toogoolawah, later Bulimba, on the south side of the Brisbane River, eight kilometres downstream from the settlement. Her memoir, Memories of Days long gone by. By the Wife of an Australian Pioneer, covers her life's experiences up to 1878, set down for the sake of her children. It is the textual representation of a white colonial woman's assumed racial authority over Indigenous people.

The motives behind Mary's relationship with Aborigines were to civilise and Christianise them. Emily Cowl brought her medicine chest to the outback and Katherine Kirkland her tentative, elevated social standards as contributions to fostering civilisation. Mary's civilising aims were stronger and deeper. Viewing Aborigines as people in need of 'improvement' — an idea associated with Jeremy

2 James Henry (Harry) McConnel, Mary's eldest son, named the town of Toogoolawah, after his birthplace on the Brisbane River. J H McConnel was manager of Cressbrook from about 1871 and became sole owner in 1908, The Cressbrook Estate: The Property of Messrs J H McConnel \& Son, n.p., Sydney, ?1910: 14; Bull n.d.: 15. 
Bentham's utilitarianism - she wished to help them along the relentless tread of 'progress'. Her flagship was the adoption of middle-class British values; her rallying cry was Christianity. Kindly, energetic and sincere in Eurocentric terms, she fitted the nineteenth-century paternalistic mould of patronisation and benevolence towards the 'lower orders', ${ }^{3}$ in this case, the Dungibara people (members of the larger Waka Waka group) on Cressbrook. While her efforts to change the Aborigines were only minimally successful, her earnest attempts brought to life the dignified and sometimes humorous reactions of the Aboriginal women and girls. By representing Indigenous opposition to white control, Mary has enabled Dungibara authority and proud identity to enter the historical record, extending and deepening our knowledge of nineteenthcentury Indigenous Australians.

\section{Wealth and privilege}

Mary first arrived at Moreton Bay in the Colony of New South Wales (now Queensland) on 1 May 1849, as the young wife of an established landholder, David Cannon McConnel. McConnel was the eleventh child and fifth surviving son of James McConnel, the Scottish owner of a Manchester fine-yarn spinning firm and, from 1835, the Cressbrook Mill that manufactured lace thread. ${ }^{4}$ In 1839 at the age of 21, he gained a share of his father's fortune. Armed with his inheritance he migrated to New South Wales the following year. Arriving in Sydney, he headed north, buying stock en route and crossed into present-day Queensland via the Darling Downs. Marking trees on 15 July 1841, he claimed ownership of a 240 square-mile section of the upper Brisbane River valley, naming his property 'Cressbrook' after his family's Derbyshire estate. McConnel thereby won the reputation of being the first settler to run sheep in the area. In 1845 he bought stud Shorthorn cows from the Australian Agricultural Co. and imported bulls from England to establish what was to become a famous stud.

During a trip to Britain, David McConnel met Mary Macleod and they married on 25 April 1848 at Old Grey Friars' Church, Edinburgh. Born in Edinburgh on 4 January $1824,{ }^{5}$ Mary was the daughter of Alexander Macleod, an inlandrevenue commissioner, and Katharine, born Rose. In Edinburgh, the family lived in the comfortable southern residential areas of Newington and Morningside and later, at Lauriston, north-west of the city. An older brother, two younger brothers and a younger sister had died in infancy. Mary's surviving siblings were

3 Cf. Roberts 1979.

4 David McConnel was born on 14 October 1818 at the Polygon, a large estate built by his father in 1804 , J C I McConnel, 'The Lives of Frederic and John [sic] Anne McConnel', 1963, mfm reel 'McConnel Family Papers', John Oxley Library, p. 12, 203; Allen 1996: unpaginated.

5 Brisbane Courier, 10 January 1910: 7. 
two older brothers, a younger brother, Walter, and a sister, eight years younger than Mary. Her eldest brother died from an illness contracted during his service as a naval medical officer in the Crimean War. An interest in health, particularly of children, remained with Mary throughout her life. Well-educated (her father set 'a high value on education'), she was taught initially by a tutor, along with her then three older brothers. Later, she attended a 'Ladies' school' and, with Walter, three years her junior, went to Henderson Academy where, 'boys and girls were taught together' ${ }^{6}$

David returned to the colony with Mary at the request of his brother John who, with Henry Mort, was managing Cressbrook. The McConnels sailed on the Rev'd Dr John Dunmore Lang's second chartered ship, the Chasely. Lang, who had been promoting the emigration of industrious, virtuous and God-fearing men and women to improve the 'moral tone' of the colony, was appealing in 1849 specifically to Manchester industrialists to invest in the growth of cotton. ${ }^{7}$ As the son of a prosperous Manchester cotton mill owner, McConnel answered the call, establishing Toogoolawah (Bulimba) on the Brisbane River.

In 1849 , only seven years had elapsed since the governor of New South Wales, Sir George Gipps, had announced that the penal settlement at Moreton Bay would be closed, and the area opened to the trading opportunities of free settlement. In 1846, when the government began to expend money on public works, the population was 950, and by 1851 it had reached only 2,103. There was no store, and government building projects had to wait until Queensland became a separate colony in 1859. Streets were undefined, the layout of inner Brisbane not yet determined. Although roads inland had been surveyed and labelled, they were rutted bullock tracks that became impassable after rain. Few people owned a vehicle (the McConnels were an exception), the main means of transport being boat travel on the river, as yet unbridged. The Government Resident, Captain John Wickham, rode a horse to the settlement from his Breakfast Point residence, Newstead. An early Brisbane shop, opened in Queen Street in late 1849, was the butchery of (later to be) notorious, Paddy Mayne (a murderer who used stolen money to advance his business). Even in 1861, Brisbane 'was not a very attractive city ... with unformed streets, atrociously kept shops, and houses few and far between' ${ }^{8}$

6 Mary Macleod, afterwards Mrs David C McConnel of Cressbrook, Queensland, 'Early Recollections', n.p., n.d., pp. 1-3, 6-7. This document appears to be a manuscript precursor to Memories.

7 John Dunmore Lang, Queensland, Australia: A Highly Eligible Field for Emigration, and the Future CottonField of Grest Britain: with a Disquisition on the Origin, Manners, and Customs of the Aborigines, Edward Stanford, London, 1861.

8 Government Gazette, 11 February 1842, in Steele 1975: 303-304. After the last convict ship arrived in Moreton Bay in April 1850, the British government actively encouraged free immigration, Greenwood and Laverty 1959: 42, 44, 46-47, 38; Siemon 2003: 26, 34; W R O Hill, Forty-Five Years' Experience in North Queensland, H Pole \& Co., Brisbane, 1907: 20; McConnel, Memories, 1905: 12. 


\section{Toogoolawah, later Bulimba}

On 1 August 1849, McConnel purchased 173 acres (69 hectares) for his agricultural property. The Yugarabul meaning of Toogoolawah was said to be 'heart-shaped', from the shape of the promontory formed by the river on three sides. Toogoolawah was the name used by Mary, who also recognised that during the 1840s, it had began to be called Bulimba. Its location on the southern bank of the Brisbane River facilitated travel by carriage to Cressbrook via Ipswich. ${ }^{9}$

The McConnels' two-storeyed Bulimba House was designed and built by the firm of Andrew Petrie, one of Dr Lang's 1831 Scottish immigrants. A former Superintendent of Works at Moreton Bay, Petrie had opened a private practice in 1842 after the closure of the convict settlement. Bulimba House was one of his first private commissions. ${ }^{10}$ The first stone house in the area, with shingled roof gables made from local cedar, it was described in the Moreton Bay Courier as an Elizabethan-style 'capacious mansion' — an imposing gentleman's residence in a society where wealth, mostly invested in property, was the indicator of social worth and success. It formed a contrast with Brisbane's first private home, Newstead House (the precursor to Government House), a long, low, plasteredbrick cottage, built in 1846 on the northern riverbank for Darling Downs farmer, Patrick Leslie. ${ }^{11}$ Strategically placed on sloping ground away from rising river levels, Bulimba House faces north-west precisely 400 metres south and 400 metres east of the Brisbane River as it coils around the promontory. ${ }^{12}$ It is now located on a large block in a suburban street.

At both Cressbrook and Bulimba, the McConnels embraced the Enlightenment ideals of order, harmony and progress. Both thriving enterprises, these properties resembled self-sufficient private towns, organised along hierarchical lines of British rural society's concept of paternalism. While McConnel was the 'paternalist' by definition, Mary was his willing supporter.

Testament to progress, Bulimba by the time of its sale in 1853 had expanded to '220 acres of land, 180 of which are available for tillage'. The estate consisted of eight workers' cottages, brick outhouses including kitchen, laundry, storerooms, sheds, a carpenter's room, the smithy, stables, a coach-house, workrooms and a large, two-storeyed barn. Another cottage lay alongside the dairy, which was

\footnotetext{
9 Fisher 1987: 30.

10 Watson and McKay 1994: 141-142; William Johnston, 'Old Bulimba', The Historical Society of Queensland Journal, Vol. 1, No. 5, October 1918: 305; Fisher 1987: 37.

11 Moreton Bay Courier, 1 June 1850: 3. The Government Resident, Captain John Wickham, bought Newstead from Patrick Leslie, who was his brother-in-law, Siemon 2003: 42.

12 Personal communication from the owner in July 2004. A flood in 1841 had been one of the worst in settler experience.
} 
large enough to milk 50 cows. A boatshed stood near the wharf. ${ }^{13}$ There was an overseer (whose wife kept the poultry yard), men to manage the large dairy cow herd, farm labourers to clear and cultivate the land, a carpenter, coachman, housemaid, indoor servant, two cooks (husband and wife), and nurses to assist with Mary's first two babies.

As well as the required cotton crop, wheat, barley, maize, oats, millet, sweet potatoes, lucerne and Italian rye grasses were planted. Mary reported that, when the land was cleared of subtropical vegetation, drained and ploughed, the virgin soil encouraged 'everything [to grow] like mushrooms'. There was of course a kitchen garden, and also orchard trees, including oranges and pineapples, and banana palms. German immigrant families worked as 'vine dressers' on the grape vines. In time, ornamental trees and shrubs surrounded the house. ${ }^{14}$

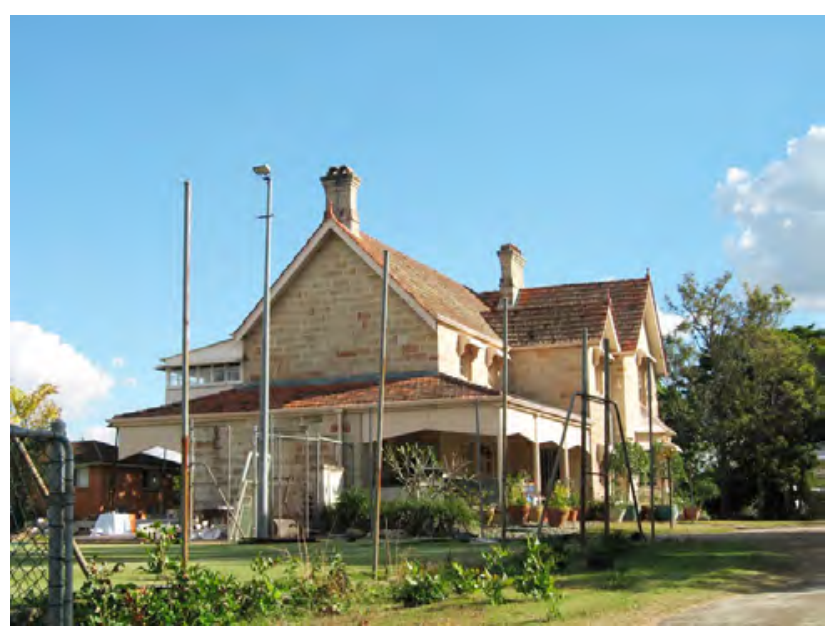

\section{Illustration 11. Bulimba homestead, now located in the Brisbane suburb, Bulimba.}

Source: Barbara Dawson, June 2006.

Mary's mention of the Turrbal people - the local men and women of the larger Yugarabul language group - is scant and did not encompass Christian outreach. The Aborigines, however, showed their curiosity about the newcomers, particularly when they thought that a church service in the South Brisbane Presbyterian Church, built by McConnel in 1850, was a white man's corroboree. Mary in this instance was not amused, judging their interference as an unwelcome intrusion. She wrote that:

13 Moreton Bay Courier, 12 February 1853: 3; Fisher 1987: 36. Cf. Conrad Martens, 'Bulimba on the Brisbane River, D. C. McConnel Esq., Nov. 21, 1851', Pencil 19 x 29.5 cm (ML PXC972, f.3).

14 Moreton Bay Courier, 16 October 1852: 2, 11 December 1852: 3, 12 February 1853: 3; McConnel, Memories, 1905: 25. 
Before [the wooden church] was enclosed the natives or "blacks" as they were called, were much attracted to it. When they saw people going in and singing, etc., they said, "Goorrai! budgery corobery!" and when the sermon began one or two of the men gesticulated like the minister, upsetting him a good deal. It was very hot and the door was open. The disturbance was prevented from happening again. ${ }^{15}$

William Johnston, whose father James was the Bulimba gardener, recorded that 'great numbers' of Aborigines remained at Bulimba and he recalled a peaceful coexistence between the races. The Turrbal continued to hunt bandicoots and pademelons with their dogs and to fish from the riverbanks, using their sophisticated fishing techniques. According to Johnston, his father had 'got on well with them and was a great favourite of theirs', being given the name 'Kiwanan'. Some of the Turrbal made 'a great display on meeting him, or even on seeing him from the other side of the river'. Johnston observed, albeit in patronising terms, that:

It is only right to say that the blacks of Bulimba were of a friendly nature, and always remembered those who had been kind to them, and to the last they could never do enough for the old farmers and their families. ${ }^{16}$

Not only friendly and accommodating, the Turrbal adapted to settler incursion by utilising available food supplies. Johnston again wrote:

The aboriginals of Bulimba were not lovers of hard work, but they were very useful in burning off, and in gathering and husking maize. They always had their dilly bags handy, and put into them all the loose grains. One [woman], "Duradnah," was employed a good deal in the house. She scrubbed the floor, and cleaned the boots - she always insisted on polishing the soles. ${ }^{17}$

For Mary, the years at Bulimba had been busy and at times tragic. Her first child, James Henry (Harry), born in 1850, experienced a near cot death after eating pineapple pulp, though 'miraculously' saved. Her brother, Walter, a licentiate of the Free Church of Scotland and the minister of Park Presbyterian Church, Moreton Bay, from 1852 to 1853 had come to live with them in 1852. He was 'always delicate and needing tender care'. ${ }^{18}$ That year her second son, Alexander, was born, and soon afterwards Mary became seriously ill with a leg infection-possibly a chronic osteomyelitis. Just as it was responding to

15 McConnel, Memories, 1905: 26.

16 Johnston 1918: 310-311.

17 Johnston 1918: 310.

18 McConnel, Memories, 1905: 27; Macleod, 'Early Recollections', n.d., written note, p. 8. 
treatment after seven months, her baby died. After these calamities, the family decided to sail for Britain. On her last visit to Cressbrook before her departure, Mary, still lame, was thrown from the carriage and knocked unconscious. Her main proselytising thrust would have to wait until she lived permanently with the Dungibara people at Cressbrook.

\section{Mary's evangelism}

Both Mary and David were Presbyterian Calvinists. At 17 Mary was spiritually converted after reading 'Doddridge's Rise and Progress of Religion in the Soul'. In her own words, 'God's hand [was] guiding me and it has governed my whole life'. Scottish author Elizabeth Haldane has observed that Calvinists 'were to live in the world the sanctified life that only those first justified by Faith could live ... this meant a life of strenuous endeavour undertaken with the help of God, and thus advancing His Kingdom'. In 1843 Calvinism split between the Moderates and the Evangelicals and Mary followed the evangelical wing that formed the Free Church of Scotland. ${ }^{19}$

Unable to proselytise in Britain beyond distributing religious tracts and booklets, Mary regarded her trip to the colony as part of God's plan. On board the Chasely, a clergyman conducted Sunday services and Mary had her first opportunity to teach religion to the children and young adults. On her decision to join her husband to the colony, she observed that:

My subsequent life, I think, proves that my Father had chosen this way for His child. I was led to decide in favour of going; the cup was a bitter one, but it had its own drop of sweetness. ${ }^{20}$

During her first visit to Cressbrook, while Bulimba House was being built in 1849, Mary reflected upon her evangelistic vocation, recalling that:

The thought came to me, surely for some purpose I had come to this fardistant life? ... and I thought there was an open door for me; not at that time exactly in Cressbrook, but in the new land to which I had come. ${ }^{21}$

From the 1820s, Protestant evangelical mission stations had spread throughout the Pacific Islands from the Marquesas Islands to Papua, endorsed by an address in the House of Commons in 1834 to introduce Christianity to 'colonial natives' ${ }^{22}$ Mary's personal mission in the colony followed the introduction of organised

19 Macleod, 'Early Recollections', n.d., p. 7; Haldane 1933: 124.

20 McConnel, Memories, 1905: 3.

21 McConnel, Memories, 1905: 21.

22 Price 1972 [1950]: 122; Gunson 1978: 11-25; cf. also Johnston 2001: 68-81; Tyrrell 1993; also, Langmore 1989. 
evangelical activity. In 1836 the Church of England Diocesan Committee of the Societies for the Propagation of the Gospel in Foreign Parts and for Promoting Christian Knowledge had been formed in Sydney for the purpose of building churches and Christian schools, distributing the Bible, Prayer Book and other religious tracts, and for supporting clergymen and missionaries throughout the colonies. ${ }^{23}$ The 'special call' of the Society was to 'make disciples of all the nations' and to start 'evangelising the heathen' ${ }^{24}$ Missionaries had long urged people to instruct the 'uncivilized part of mankind' for 'the welfare and improvement of the human race' and, in the Australian colonies, this meant converting the Aborigines. Women were particularly singled out for this 'great duty'. ${ }^{25}$

In the debate as to whether 'civilising' should precede conversion, the Western Australian settler Alexander Collie wrote to his brother in 1831, expounding the merits of 'civilising':

there is here an excellent field for the missionary. Young [Indigenous] boys could easily be accustomed to value the comforts of civilized life and thereby [have] our moral and religious habits instilled into them. Even the older might, I think, be readily educated. ${ }^{26}$

Nineteenth-century poet and hymn writer James Montgomery believed, however, that the best way to convert Aborigines was to follow Biblical text. His opinion was: 'The wisdom of man says, "First civilize, and then Christianize barbarians"; but ... The counsel of God is the reverse; "Go and preach the gospel to the Gentiles ... you will civilize them by Christianizing them"'”. Evangelical clergy naturally recommended this approach. ${ }^{27}$

The combination of religious training, the introduction of British cultural standards, education and the targeting of children were all part of Mary's Christianising quest.

\footnotetext{
23 A Statement of the Objects of the Committee of the Societies for the Propagation of the Gospel in Foreign Parts and for Promoting Christian Knowledge (Australia), Stephen and Stokes, Sydney, 1836: 4 (NLA mc N 1475, item 7186).

24 Pascoe 1901: ix.

25 Letter from 'The London Missionary Society to Governor Hunter', October 1799, Letter from 'The London Missionary Society to The Missionaries at Sydney', in F H Bladen (ed.), Historical Records Of New South Wales, Vol. III-Hunter 1796-1799, Charles Potter, Sydney, 1895: 731-732.

26 Quoted in Hetherington 2002: 115. This mission focus continued into the twentieth century, McGrath 1995: 189.

27 Maxwell 2001: 124, 123; Gunson 1978: 267 (italics in original).
} 


\section{Taking Alpin Edward Durundur to Britain}

Mary undertook a drastic measure in her efforts to civilise the heathen, concentrating first on one particular young boy. When she and David returned to Britain on 13 December $1853,{ }^{28}$ they took with them a seven-year-old Durundur boy, 'found' by Cressbrook's then overseer, Alpin Cameron, on Durundur station - at that time a part of Cressbrook. Cultural confidence and ignorance were her drivers. Selected because he was an 'orphan', the Aboriginal lad would have been, as we now know, part of what Anna Haebich has called the 'overlapping circles of extended family [that] lie at the heart of the lives of most Aboriginal Australians'. From childhood, Aborigines connect with their culture through their networks of family relationships, learning through their kin where they come from, who belongs to them and how they should behave within a 'wide universe of kin'. ${ }^{29}$ Mary, however, could not have understood that the boy's identity was cast within deep cultural knowledge and extended kinship ties.

Mary hoped for, and no doubt expected, the best. The boy 'promised well', and Mary's ethnographical description of him places her among the nineteenthcentury, dispassionate scientific appraisers of human beings. He was:

an average specimen, well-made, not good-looking, he had, like all Australian natives, nice hair, smooth and not coarse. He could not speak any English. Until he went on board ship he wore only a little shirt, but as the weather became cooler he was glad of more clothing, and he very readily adapted himself to the change of circumstances. ${ }^{30}$

The feelings of Alpin - as he was later called - are hidden and can only be imagined from the scant record of his actions and perhaps from the reactions of those who saw him. On board ship he was 'well behaved' and 'became quite a favourite'. In Yorkshire, in the way that P T Barnum's exotic human 'exhibits' were later received, he was regarded as a 'seven days' wonder' and casual observers thought he was a young, black 'devil'. This idea linked the boy to the tradition of the morality play that had long conditioned audiences to identify 'blackness' with the devil. 'Blackness', in character as well as appearance, signified to an evangelical Christian the need for redemptive intercession. Alpin unknowingly compounded this image by innocently disregarding the Sabbath

\footnotetext{
28 'Departure for Sydney of Iron Prince with passengers, Mr and Mrs D.C. McConnel, nurse and child', Moreton Bay Courier, 17 December 1853: 2.

29 Haebich 2000: 13.

30 McConnel, Memories, 1905: 41.
} 
by going 'bird-nesting', earning him the reputation of being a 'very naughty little boy'. Mary preferred to describe him as a 'good-natured' lad, who had 'tamed-down', and was learning to speak English. ${ }^{31}$

First moving from place to place around Britain with the McConnels, Alpin was then left with Mary's sister in Scotland while Mary and David toured France, Italy, Switzerland and Germany for one year. This entourage included their now three children, McConnel's nephew, two nurses (Scottish and French) and their driver. We learn little of Alpin's well-being through bland reports that he had a 'happy, healthful year' and 'grew intelligent', and was 'quite contented'. On the McConnels' return to England, he lived with them in south London, where David bought a house on two and a half acres of land at Tooting Common-later extended to accommodate their increasing number of children. Mary wrote favourably on the boy's intellectual success at weekday school, and his spiritual progress at Sunday school. By the end of another year, the minister of the local church wished to baptise him. Here he was given his English names, Alpin Edward Durundur' - 'Edward' (the name of his schoolmaster) being the only one he himself chose. ${ }^{32}$

Whether these conditions suited or upset Alpin, he had no choice but to accept them. Mary pointed out that family members treated him 'in every way as we would were he a white boy', without specifying qualifications in the relationship, or Alpin's reaction to his circumstances, other than his apparent compliance. The way Alpin chose to spend his free time, however, gives a clearer insight into Mary's hopes to 'assimilate' him. She records without illusion, that:

[Alpin] dearly loved all "spectacles"; a circus was his delight; he was never inside a theatre. We were not far from the Crystal Palace [built for the Great Exhibition of 1851]; he had a boy's ticket, and it was his delight to spend Saturdays and holidays there. We often sent the nurses and children. He loved the Church of England service, never omitted a response, and would go three times to Church on Sunday, if there were three services. I do not mean to suppose it was only devotion that prompted him, but more love of "spectacle". ${ }^{33}$

After three years in London, the McConnels returned to Scotland, where Alpin continued his 'excellent progress' both at school and in sport. Throughout the nine years that Alpin was to remain in Britain, Mary could report that he was well behaved, 'obedient and tractable' and 'honest and truthful', and seemed surprised with her comment: 'Somehow I do not think it occurred to him to tell a lie'. Nor did he use 'bad words'. Perhaps his behaviour reflected his closeted,

31 McConnel, Memories, 1905: 41.

32 McConnel, Memories, 1905: 38-41.

33 McConnel, Memories, 1905: 41-42. 
repressed-even depressed-existence. As he reached adolescence, he 'began to improve in looks and was well-grown'. Rather than hiding his difference, he was proud of his shiny, wavy black hair-'his chief extravagance' being 'an occasional sixpence for hair oil'. ${ }^{34}$

Mary was confident that her plans to control Alpin's future within a colonised world had been successful. He had been educated and taught a trade, baptised into the Christian church and had adopted some 'civilised' activities. When she and David returned to Queensland in 1862, they took the 16-year-old youth with them, rationalising that the trade of carpentry that he had chosen to follow in Britain would be similarly available to him in Queensland, where they would moreover be able to give the adolescent their 'watchful care'. However, like the experiment with Bennelong before him, Mary McConnel's also failed. ${ }^{35}$

The denouement of Mary's long-term hopes and plans for Alpin Durundur was pathetic. Like Bennelong, Alpin felt the pull to return to his own people, and determined to turn his back on white society. In retrospect, Mary acknowledged that, 'In truth we ought not to have taken him back to the scenes and people of his old savage life. We did it for the best, wishing to keep him under our own eyes'. Her account of Alpin's escape unfortunately leaves the Durundur man's fate unresolved. She recorded that:

he had so long enjoyed a civilised state that we thought he would not care to return to his old life, but the old scenes and his tribe who lionised him were too much for him, and he said one day, "I am tired of this sort of thing," and became restless. So we thought it best to send him back to the Old Country, and my husband made good arrangements with a very nice kind captain to take him home in his ship. We did not tell Alpin till he was on board. I had packed his box, putting in little things I knew he would like. My husband took him to Brisbane the evening before the ship sailed, went on board with him, told him that he was going back to his friends who had been so kind to him, and that he would come back in two or three years, gave him half-a-sovereign and said goodbye, leaving him with the captain. But the same night he swam ashore, bought a tomahawk, and went into the far-away bush. He never came back, which was a grief to me.

\footnotetext{
34 McConnel, Memories, 1905: 42.

35 Bennelong was captured on orders from Governor Phillip in 1789. In December 1792, he sailed with Phillip to England and was presented to George III. He returned home in 1795 with second New South Wales governor, John Hunter, after suffering from homesickness and the effects of the cold climate. Imeerawanyee, who had accompanied Bennelong, died in England, Aplin, Foster and McKernan 1987: 45.
} 
Mary rationalised her failure with the explanation that she wrote at length about Alpin 'to prove that they are not by any means so low down in the scale of the human race as they are generally supposed to be'. ${ }^{36}$

\section{Cressbrook}

Racial conflict in the Darling Downs and Lockyer Valley had been rife in the 1840s and 1850s. The Moreton Bay Courier reported instances of Aborigines spearing or stealing sheep and the retribution meted out, some in the 1850s by the notorious Native Police force. ${ }^{37}$ In the Brisbane River valley, David McConnel and his brother, John, had been caught up in the inevitable conflicts between blacks and whites and their struggles over land. A younger brother, Frederic, who was to return to Britain in 1845 , had taken a peaceful path. ${ }^{38}$

In 1862 John McConnel took over the formerly joint-owned Durundur, 50 kilometres to the north-east, near the present town of Woodford, leaving David as the sole owner of Cressbrook. According to John's son, A J McConnel, David McConnel and his neighbours had undertaken 'stern work' against the Waka Waka people in the 1840s and 1850s, joining forces for protection and constituting themselves into 'a court of justice to administer punishment' ${ }^{39}$ In an 1844 letter to his mother and sister, Cressbrook's manager Henry Mort referred to David's attitude towards the Aborigines:

John and David McConnell [sic] argued that it is morally right for a Christian Nation to extirpate savages from their native soil in order that it may be peopled with a more intelligent and civilized race of human beings ... F [Frederic] McConnell and myself were of the opposite opinion. ${ }^{40}$

Whether Mary knew of this bloodied past is uncertain. Her daughter, Mary Banks, had certainly learned enough to acknowledge violence against the Aborigines in the McConnels' history, writing in 1931 that:

\footnotetext{
36 McConnel, Memories, 1905: 42-43. Christina Smith, who lived for 35 years as a lay missionary and teacher, similarly wrote that, 'It is a general opinion among Europeans that the aborigines ... are too low, intellectually and morally to be Christianised or civilised. [This is] entirely erroneous', Mrs James Smith, The Booandik Tribe of South Australian Aborigines: A Sketch of their Habits, Customs, Legends, and Language: Also: An Account of the efforts made by Mr. and Mrs. James Smith to Christianise and Civilise them, Government Printer, Adelaide, 1880: 33.

37 Steele 1975: 299; McConnel, Memories, 1905: 18. John Uhr was speared at an outstation on the Brisbane River in December 1845, Kerr 1988: 10. Edmund Uhr and family had moved by June 1850, Moreton Bay Courier, 1 June 1850: 1, 29 June 1850: 4, 27 November 1852: 3, 4 December 1852: 3, 11 December 1852: 2.

38 'McConnel Family Papers', microform no. 755399, State Library of Queensland, 'The Lives of Frederic and John Anne McConnel', p. 12.

39 Evans, Saunders and Cronin 1993: 113.

40 Letter from Henry Mort, 28 January 1844, in Reynolds 1996: 4.
} 
It was not till years after my childhood that I learnt of cruelties to the blacks, and I refused at first to believe it possible. This I know, that there were very many places where the natives were treated with kindness and affection, and that much of the harshness was due to ignorance and misunderstanding. But for actual cruelty, which unfortunately cannot be denied, no excuse is possible. ${ }^{41}$

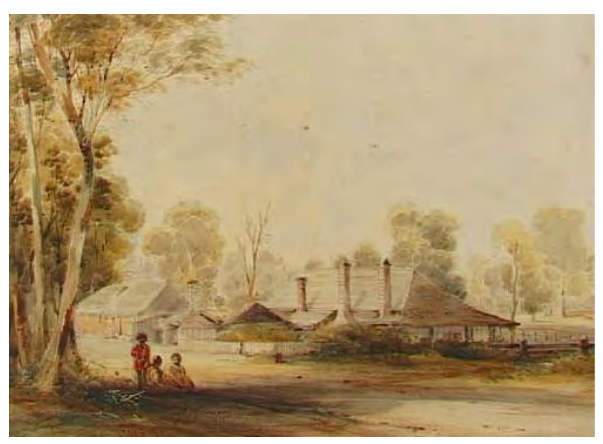

\section{Illustration 12. Cressbrook homestead, Dungibara left foreground.}

Source: Conrad Martens, England/Australia 1801-78, 'Cressbrook looking N.W.' 1852, watercolour, 18.7 x $28.3 \mathrm{~cm}$. Private collection.

When Mary returned to live at Cressbrook in 1862 the frontier struggle had long been resolved. Nestling comfortably within the confines of the established working pastoral property were homestead, outbuildings and an English garden. Some hints of what had occurred find their way into Mary's narrative. They relate to a distant past and all refer to violence enacted by Aborigines. For example, John McConnel's reason for selling the cattle station Crow's Nest was because: "The "blacks" were very troublesome. He did not like being there'. Edmund Uhr of Wivenhoe station planned in 1849 to move to town with his wife and daughter because, '[His] brother had been murdered by the natives, and [the Aborigines] continued troublesome'. Of Cressbrook, she wrote that 'one or two of the [Aboriginal] men were treacherous, that they speared cattle, once an imported bull from England', although she seems hasty to absolve the men from blame because 'they had no idea of the value of the animal'. ${ }^{42}$

Mary's contemporary from the northern rivers district of New South Wales, Emma Macpherson, who knew that her husband '[waged] a perpetual guerilla warfare with the wild tribes' when he was living in 'the far North-West', later

41 Mary Macleod Banks, Memories of Pioneer Days in Queensland, Heath Cranton Limited, London, 1931: 42-43. Mary Banks, Mary's sixth child, born in England in 1861, offers a complementary and qualifying perspective of life at Cressbrook, where the author spent her childhood.

42 McConnel, Memories, 1905: 11, 18, 43. 
presented her husband as 'always [having] taken a great interest in [Aborigines], and been perhaps a little too liberal with them'. Mary likewise projected a peacemaking McConnel, who had 'set himself at once to make friends with [the Aborigines], and they soon got to like and trust him'. She added enigmatically that, 'He never failed to do what he promised'. ${ }^{43}$

Mary's writing represents a time when the settlers had emerged the victors, to reign over a tamed environment of both people and landscape. Interracial distrust and tensions seemed to have dissipated. This time difference between grasp and conquer freed Mary's text from the dilemma of guilt and friendship that swirled as an undercurrent in Katherine Kirkland's account.

Cressbrook's resident Aborigines were, to all intents and purposes, working to assist the McConnels' plans for a civilised and progressive enterprise. Mary could portray her husband as a benign master of men and was able to concentrate on her own benevolent role, which she as coloniser played in the civilising of the colonised. Her undisputed status enabled her to adopt the tone of a patronising mistress exerting (or endeavouring to exert) control over the Indigenous owners of the land.

As paternalists, the McConnels had conscientiously taken up their duty to guide and help their workers who, in turn, were expected to render to their benefactors loyal service, and to be punctual, polite and show due deference to their master's authority. ${ }^{44}$ The Masters and Servants Act 1857 (NSW) formalised in law the already existing expectations of employer and dependant employees, defining as servants:

all agricultural and other laborers [sic] shepherds watchmen stockmen grooms all domestic and other servants artificers [sic] journeymen handicraftsmen gardeners vine dressers splitters fencers shearers sheepwashers reapers mowers haymakers hired and engaged in this Colony. ${ }^{45}$

Aborigines were included in this mix.

Mary underlined her own attitude by reiterating McConnel's autocratic carrot and stick method of control:

43 Mrs Allan Macpherson's My Experiences in Australia, Being Recollections of a Visit to the Australian Colonies in 1856-7. By a Lady, J F Hope, London, 1860: 231, 203. Cf. Foster 2010; McConnel, Memories, 1905: 43.

44 Roberts 1979: 1-8. Colonial landholders extended their paternalistic care whether they lived on their properties or were absent owners. Cf. Dawson 2000: 123-139; and Dawson 1999: 20-28.

45 'An Act to regulate the Law between Masters and Servants', 20 Victoria No. 28, 11 March 1857, in The Public General Statutes of New South Wales (1852-1862), Government Printer, Sydney, 1862: 3081-3084. 
When the tribe behaved badly my husband would not allow them to come up to the head station, nor give them presents, - a shirt, or red pocket-handkerchief, tobacco or a pipe; when they did no work they got no rations. ${ }^{46}$

The white man's perception of Indigenous Australians as inferior to Europeans had been ratified by law: the Licensed Publicans Act 1838 (NSW) forbade the sale or gift of alcoholic drink to Aborigines. ${ }^{47}$ Restrictive liquor laws were similarly incorporated after 1859 into Queensland legislation that continued in like vein into the twentieth century. The Aboriginal Fire Arms Regulation Act 1840 (NSW) disallowed the use of firearms by either 'Aboriginal natives and half-castes' unless by special permission. ${ }^{48}$ The Queensland Elections Acts of 1872 and 1874 underlined Aboriginal legal inferiority by including Indigenous Australians amongst those not entitled to vote unless possessors of property under British freehold title. ${ }^{49}$

When building up her picture of life at Cressbrook, Mary focused on the care she and her husband extended to the members of the large white workforce by providing a schoolroom, paying for a teacher for the workers' children, and setting up a room as a library for the men. They later supported the building of a public school at Esk. At Bulimba, Mary's chief aim had been to proselytise to the children, a practice encouraged in evangelical missions. Mary had taught a large class of Sunday school girls, while McConnel taught the boys. As respectful children of Bulimba workers, they were 'very regular in their attendance, prepared their lessons well, and were quiet and attentive'.$^{50}$ Education was incorporated into religious instruction by having the older children read their lessons out aloud to the McConnels.

Mary's main narrative focus was on her educational and evangelistic methods at Cressbrook. There, religious observance was strict, 'the Lord's Day [being] kept reverently [with a] complete cessation from labour'. During the early 1850s, McConnel had led a service on the Cottage veranda, using the Church of England service, and reading 'very good sermons'. By 1864, the McConnels employed a Presbyterian minister. In later years, Mary attempted to establish a United Christian Church in a chapel built near the homestead, a plan that ultimately failed because the Church of England, Presbyterian, Wesleyan and Methodist clergymen (who took the service for one week in turn) argued against

\footnotetext{
46 McConnel, Memories, 1905: 43.

47 An Act for consolidating and amending the Laws relating to the licensing of Public- houses, and for further regulating the Sale and Consumption of Spirituous Liquors in New South Wales'.

48 'An Act to prohibit the Aboriginal Natives of New South Wales from having Fire Arms or Ammunition in their possession, without the permission of a Magistrate'.

49 McCorquodale 1987: 19-20, 53.

50 Sangster 1963: 26; McConnel, Memories, 1905: 25.
} 
the teachings of the previous week. ${ }^{51}$ To commemorate the McConnels' twentyfifth wedding anniversary in April 1873, David bought land in nearby Esk for the 120-seat weatherboard Presbyterian Church of St Andrew, consecrated on 2 February 1876. He also built a spacious manse. ${ }^{52}$

As at Bulimba, Mary tried to reach the workers through her Sunday school children, to whom she distributed Good Works, Sunday Magazine and Sunday at Home, and the Rev'd Dr (later Bishop) Ryle's 'famous Xmas tracts'. She enjoyed teaching the children to sing, and was heartened when she heard them singing hymns as they walked along the river on Sunday afternoons.

By the 1860s some of the Dungibara had adapted to colonisation by choosing to be 'station Aborigines', trading their labouring skills for the opportunity of remaining on their ancestral land along the banks of the Brisbane River. This symbiotic relationship, explored by historians such as Tim Rowse and Robert Foster, was one in which Aborigines 'came to ... realise the value of good conduct', as they learned to adapt to the settlers' demands. ${ }^{53}$

The rub was that adaptation under the McConnels entailed pressure on the Aborigines to conform to the requirements of a British paternalistic social structure, in the pattern of daily life set by a white mistress.

\section{Civilising the Dungibara?}

In her plans to evangelise to the Aborigines on Cressbrook, Mary followed an established path followed in colonial society of first introducing to Indigenous children the British cultural standards of behaviour, combined with religious training. The fact that she had failed with Alpin Durundur did not deter her or deflect her aim.

Assuming a superior and privileged position over the Indigenous children, Mary tried to gradually separate 'Topsy' and 'Clara' (the daughters of Aboriginal women, Kitty and Polly) from their families. She arranged a room in the homestead, where she kept their clothes, and she encouraged the girls to take a tepid bath each morning. Although Mary had also hoped that they would sleep overnight in warm beds, she could not 'wean them from going off to the camp at night to sleep by the camp-fire'. The only success was that she had taught them

51 McConnel, Memories, 1905: 20; Kerr 1988: 216; Banks 1931: 36.

52 Kerr 1988: 216-217. Harry McConnel followed in his parents' tradition by building a chapel on Cressbrook in 1901 on the occasion of his own twenty-fifth wedding anniversary, The Pastoralists' Review, Vol. XX, No. 11, 16 January 1911: 1217.

53 A J McConnel, 'Some Old Stations', cited in Evans, Saunders and Cronin 1993: 113-114; Tim Rowse, White Flour, White Power: From Rations to Citizenship in Central Australia (1998) explores the relationship which evolved around the practice of rationing in Central Australia from the 1890s; cf. also Foster 2000. 
to read a little, to sew, and to repeat and sing 'simple verses and hymns'. Her attempts to break the pattern of the Dungibara's cultural practice of gathering in the mountains with neighbouring groups were similarly fruitless. Mary reported that 'nothing would induce them to leave the little girls behind' ${ }^{54}$ Despite her plan to disrupt and disintegrate this collective cultural activity by holding back the girls, Mary revealed through her own disappointment of their resistance to her, the Dungibara's firm hold on their identity.

The Indigenous girls seemed to react cavalierly to Mary's attempt to Christianise and 'civilise' them. Their flippancy and humour demonstrate their incomprehension, and their cheeky disdain for the different and strange workings of the white woman. Although Topsy (a little girl 'full of mischief') and Clara attended Sunday school, when the teacher told them God 'loved them and wished them to be His very own children', Topsy retorted, 'Ah! Miss Shmit, suppose God love me like that, what for he make me black?'. Again, a young woman visiting Cressbrook asked for the care for the girls. Leaving them alone at the homestead while she went out riding, the girls soon found an excuse for having fun. In her absence:

[Topsy and Clara] entered her room, ransacked her drawers, dressing themselves up in her clothes and putting on what trinkets they could find; while admiring themselves in the looking-glass they heard footsteps and scuttled under the bed! ${ }^{55}$

How did the Aboriginal women at Cressbrook deal with the patronisation of a well-meaning master and mistress and the pressure they exerted on them to become 'civilised'? And how did Mary, within the constraints of class, race and religion, choose to represent the Aboriginal women with whom she shared a physical closeness, as the Aborigines carried out domestic chores in the homestead? Indigenous dignity, adaptation and sense of humour came to the forefront and Mary portrayed some of the women's responses.

The Dungibara women were allowed to enter the house only as workers and only after having complied with the basic British middle-class virtues of cleanliness and tidiness. In condoning the close relationship between her first-born child, who as a baby was 'very fond' 56 of Long Kitty, Mary gave the Aboriginal woman 'a comb and a loose red gown, and she would come up [from bathing in the river] very smart, with her hair parted' in preparation for looking after Harry. This dictum that Aborigines comply with English working standards was to

54 McConnel, Memories, 1905: 44. The German missionaries at Mount Zion on the Brisbane River had held school classes for Aboriginal children, with an emphasis on Scripture and prayer. Girls were also taught sewing, Steele 1975: 335.

55 McConnel, Memories, 1905: 44-45.

56 I have consistently wondered if 'very fond' encompassed a bond between Harry and the Aboriginal woman that involved breastfeeding. 
endure on outback stations into the twentieth century. In the late 1970s, Ann McGrath interviewed a white woman from the Northern Territory who recalled that Aboriginal women were required, 'Every morning ... to wash, change their dresses, and comb their hair in the wash-house before starting work' - a form of domestic training seen as "an ideal means of "uplifting" the part-Aboriginal women, for it taught black women the observance of British white cultural norms and middle-class etiquette - at least while in the employers' home' ${ }^{57}$

Long Kitty found a way to both comply with and ridicule the demands imposed on her. When she emerged from the river, spruce and cleansed to British codes of conduct, she would mischievously retort: "likit missus"[?] - and ask for the baby'. Her words expressed elements of resistance and negotiation that bespoke power, not powerlessness. Pride in her land elicited an explicit expression of authority. Stretching out her arms, she told Mary: All this "yarmen" (land) belonging to me'. This open statement against the imposition of white culture serves as an example of what literary theorists Barry Morris and Anne Brewster have coined, 'developing a politics of identity' ${ }^{58}$ Although Mary had replicated an Indigenous woman's voice and her claim over the land, she included her own response that, 'It did seem hard to have it all taken from them, but it had to be. They cultivated nothing; they were no use on it' $^{\prime 59}$

Mary's ethnocentric attitude replicated the current justification for taking Aboriginal land. Dr Lang, who followed the 'doomed race' hypothesis, expressed similar sentiments, asserting that there was 'no fault in taking the land' from Aborigines. Emma Macpherson similarly contended that in the interests of humanity and the cause of civilization and progress ... it was the especial hand of Providence which, when the old world was [becoming too crowded] this fair new land [was found]'. ${ }^{60}$

Another story-concerning a woman termed 'Kitty' - shows Indigenous ingenuity in circumventing Mary's supercilious control (in the guise of matriarchal care) over the Aborigines. While Mary placed the Indigenous woman in the subservient position of a somewhat recalcitrant child, to be scolded, then forgiven, Kitty showed her authority in her ability to manipulate white attitudes and expectations in order to achieve her own ends. She exercised her authority through discrete and indirect means. Mary reported of Kitty, originally from Durundur, that:

\footnotetext{
57 McConnel, Memories, 1905: 43; McGrath 1987: 66, 60.

58 Morris 1989, in Brewster 1996: 13.

59 McConnel, Memories, 1905: 43. Early settlers, Edward Curr (1841-1851, present-day Victoria) and Robert Christison (central western Queensland, 1864-1910) also identified with Aboriginal concerns. Unlike Mary McConnel, however, they did not try to 'christianise' their station Aborigines, Curr 2001 [1883]; Bennett 1927.

60 Baker 1985: 112; Reynolds 1996 [1987]: 171; Macpherson, My Experiences in Australia, 1860: 236-237.
} 
Once on my return from England I had bought a piece of red serge to make the native women winter dresses - a loose gown with short sleeves, coming down about half-way from the knee to the ankle. Kitty was very proud of hers, and begged me to allow her to go to Durundur to show it to her sister. It was the rule that when the tribe started on their expeditions they left their good clothes behind, generally wearing the opossum-rugs made by themselves. I gave her leave. By-and-by she returned minus the red serge gown; I said, "Kitty, where gown?" She said, "Missus, baal you be woola (don't be angry), my sister bin say, 'give it me gown, kind missus give you 'nother,' and I ben give it her." I pretended to be very angry. She said, "Poor sister baal (not) got it gown." It was quite true what she said, so after a little I gave her another. ${ }^{61}$

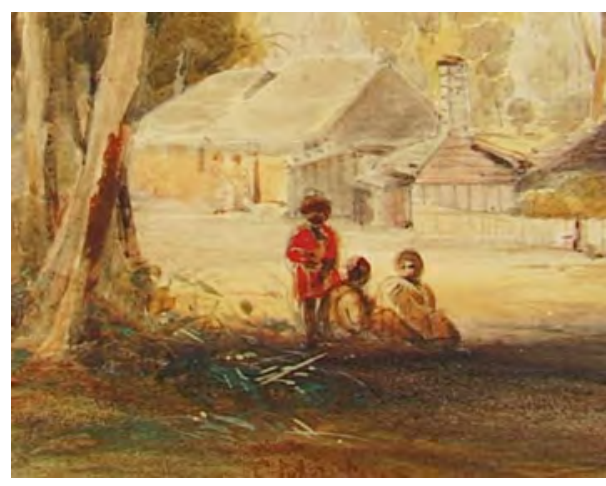

\section{Ilustration 13. Dungibara child wearing red coat.}

Source: Conrad Martens, 'Cressbrook looking N.W.' [detail] 1852, Watercolour. Private collection.

Mary Banks, from a different perspective as a child growing up among the Dungibara, evoked the idea of friendship from the peaceful co-existence of Aborigines and settlers on Cressbrook. From her point of view:

The coloured folk living about us were our friends. We spoke of them as 'the blacks'. One woman, Kitty, came to scrub the kitchen and veranda floors; she said I was her dead baby girl 'jumped up white,' and treated me with every mark of affection. She had a keen sense of humour and we often laughed together. Her husband, Piggy, worked at odd jobs to earn pence for tobacco; Kitty also smoked and had her pipe, and they had rations from the station store. They camped with others of their 
tribe on the river bank near the station, speared fish for us, and walked about with their blankets over their shoulders, watching the strange doings of the white man. ${ }^{62}$

According to Mary Banks' interpretation, the Dungibara 'respected [her] father's property': they had learned to adapt. She depicted a relationship of acceptance and cooperation in which the McConnels also respected the Aborigines' 'rights to camp in the old haunts, to hunt kangaroos, opossum and fish, and to hold the Bunya-nut feast on the hills'. Banks remembered with affection how 'King Billy' would carry her as a little girl on his shoulders over the river to the Aborigines' camp, and bring her native berries to eat - surely authoritative and protective gestures. She reported also that, when the family returned home after short visits to Ipswich, some of the Aborigines would line up and clap their hands in welcome. ${ }^{63}$

Mary senior wrote sympathetically in general terms about the Aborigines, considering them 'much maligned'. She knew some of the Aboriginal women and girls well enough to individualise them, referring to them by their English monikers and describing their appearance and personalities, although keeping to such stereotypical terms as 'very pretty' and 'affectionate'. According to Mary, Kitty 'grew very fond of [her] and the children'. Mary mentioned Aboriginal men only in relation to their behaviour towards their wives, empathising with the women with her comments that 'Piggie Nerang' (Kitty's husband) was 'not worthy of her'; and that Polly, 'another fine "gin"', was 'very cruelly used by her husband, she had her teeth knocked out; but she was a gentle creature' ${ }^{64}$

Unlike Indigenous women on Victorian missions between 1860 and 1886, described in Diane Barwick's 'And the lubras are ladies now', ${ }^{65}$ the Dungibara women appeared to be largely impervious to Mary's efforts to civilise them. Nor could Mary record any successes in conversions to Christianity. While the mission women grasped the opportunity to improve their social position by increasing their religious status in white society - a move that increased their power in Aboriginal society as they assumed equal marital status with their menfolk - the McConnels had tried to lock the Dungibara into the position of menial workers under a dominant master and mistress within a pastoral economy. Within this mould, the Aborigines held firm to their own cultural identity. ${ }^{66}$

62 Banks 1931: 41.

63 Banks 1931: 41-44, 46.

64 McConnel, Memories, 1905: 43-44, 45.

65 Barwick 1974: 51-63.

66 This finding complies with Ann McGrath's argument in 'Born in the Cattle' (1987) that Aborigines on pastoral stations in the Northern Territory negotiated their own terms of adjustment. Also cf. Rowse 1988: 57-73. 
In spite of Mary's narrative tone of superiority towards the Aborigines, the Dungibara assisted, accommodated and protected the settlers. The homestead is located on a saddle of land between the Brisbane River and Cressbrook Creek. It is believed that the Dungibara advised McConnel against his first choice of position, warning him that streams were known to meet and flood in that area. It now faces north across river flats.

Furthermore, 'King Billy' took on the role of protecting McConnel. For years after the 1842 murders at Kilcoy, when over 50 Dallambara people were fed poisoned flour at Evan and John MacKenzie's Kilcoy station (which shared a north-eastern boundary with Cressbrook), the Dallambara vowed to kill any white man who travelled through their country. When McConnel planned to blaze a new trail eastward to Brisbane through Dallambara territory, having ignored the warnings of the Cressbrook Aborigines, 'King Billy' accompanied him, running beside McConnel's horse. At the Indigenous land border, Billy assured McConnel safe passage by assigning him to the care of the Dallambara 'chief'. ${ }^{67}$

\section{Christian Kanakas}

Failing to convert the Dungibara, Mary took comfort in the benevolent care she could extend to eight Kanakas, who worked on Cressbrook for three years in the1860s. Kanakas (Pacific Island workers) were first imported into Queensland in 1863 to fill a manpower shortage after work by convicts ended and attempts to employ Aborigines or Chinese as shepherds failed. ${ }^{68}$ The first Kanakas were from Hawaii. These men were gentle and 'happy-natured', and Christian. ${ }^{69}$ Mary was pleased that they said grace before eating. She supported their faith by buying for them 'copies of one or two of the Gospels in Mari language, also English testaments in good type, also copy-books and slates' to help teach them to read. She described how:

In winter we had school at night, in summer at 5 a.m. on the veranda; their copies and sums were set the night before, my dear husband helping me. They arranged that in turn one should weekly stay away to prepare breakfast; work began in the heat at 6.30. It was a pleasant time, they teaching me Mari and I them English. They learned to repeat a good deal of Scripture in their own language, also the Lord's Prayer. They loved singing songs and hymns. ${ }^{70}$

67 Banks 1931: 43.

68 Greenwood and Laverty 1959: 46; Molesworth 1917: 140.

69 Banks 1931: 46-47.

70 McConnel, Memories, 1905: 49. 
David McConnel undertook the task of advising the men on managing their finances, which comprised £6 a year, food, lodging, clothing, and their ship's passage to and from their homeland. He dissuaded them from buying from hawkers that called at the station and organised a bank account for them so that they could save their money. After they did extra work with the cattle, or the special jobs of sheepwashing and shearing, McConnel paid them each 10 shillings, and 'this they could spend as they liked'. To assist them, Mary bought whatever they needed on her trips to Brisbane. ${ }^{71}$

In her later years, Mary continued to espouse her evangelistic and paternalistic attitudes towards the Aborigines, although slightly less stringently. She recorded that:

At last after long years of ill-usage the natives, such as are left, are being thoroughly well cared for, humanely and wisely treated, not by forcing them to cultivate habits, but by giving them a certain amount of liberty, teaching them to be a law-abiding people, above all seeking to win them for the Master. Away in the North, not far from Thursday Island, where the natives are comparatively numerous, there is splendid and successful work being done by the Moravian missionaries under the control of the Presbyterian Church of Australia. ${ }^{72}$

\section{Brisbane's Hospital for Sick Children}

In 1875, Mary and David bought Witton Manor, situated ten kilometres upstream from Brisbane in the present-day suburb of Indooroopilly, where they lived until 1878. Distressed by the many accidents and illnesses afflicting the children of immigrant families living near Witton Manor, in 1876 Mary set up a fund to establish the Hospital for Sick Children. It opened in temporary accommodation at Spring Hill, Brisbane, on 11 March 1878. With financial support from the government, in October 1883 it became a permanent hospital, now known as the Royal Children's Hospital. The Ladies Committee, formed by Mary in 1877, governed the hospital until $1924 .^{73}$

From her first arrival in the colony in 1849, Mary returned to Britain 13 times. These trips included extended residence in England and Scotland from 1854

\footnotetext{
71 McConnel, Memories, 1905: 49-50.

72 McConnel, Memories, 1905: 45. During the nineteenth century, Moravian missions spread throughout the world. The missionaries at Nundah (Mount Zion) were Moravian, Maxwell 2001: 133-134; Schindler 1916: 64. 73 Mrs David C McConnel, Our Children's Hospital: A Story of Twenty-one Years 1876 to 1897, Thomson Brothers, Brisbane, 1897: 12-18; Pearn 1993: v.
} 
to 1862,1871 to 1873 , and between 1878 and 1881. After McConnel died in England in 1885, Mary returned to Cressbrook to live, where she resided as the matriarch of her large, successful family.

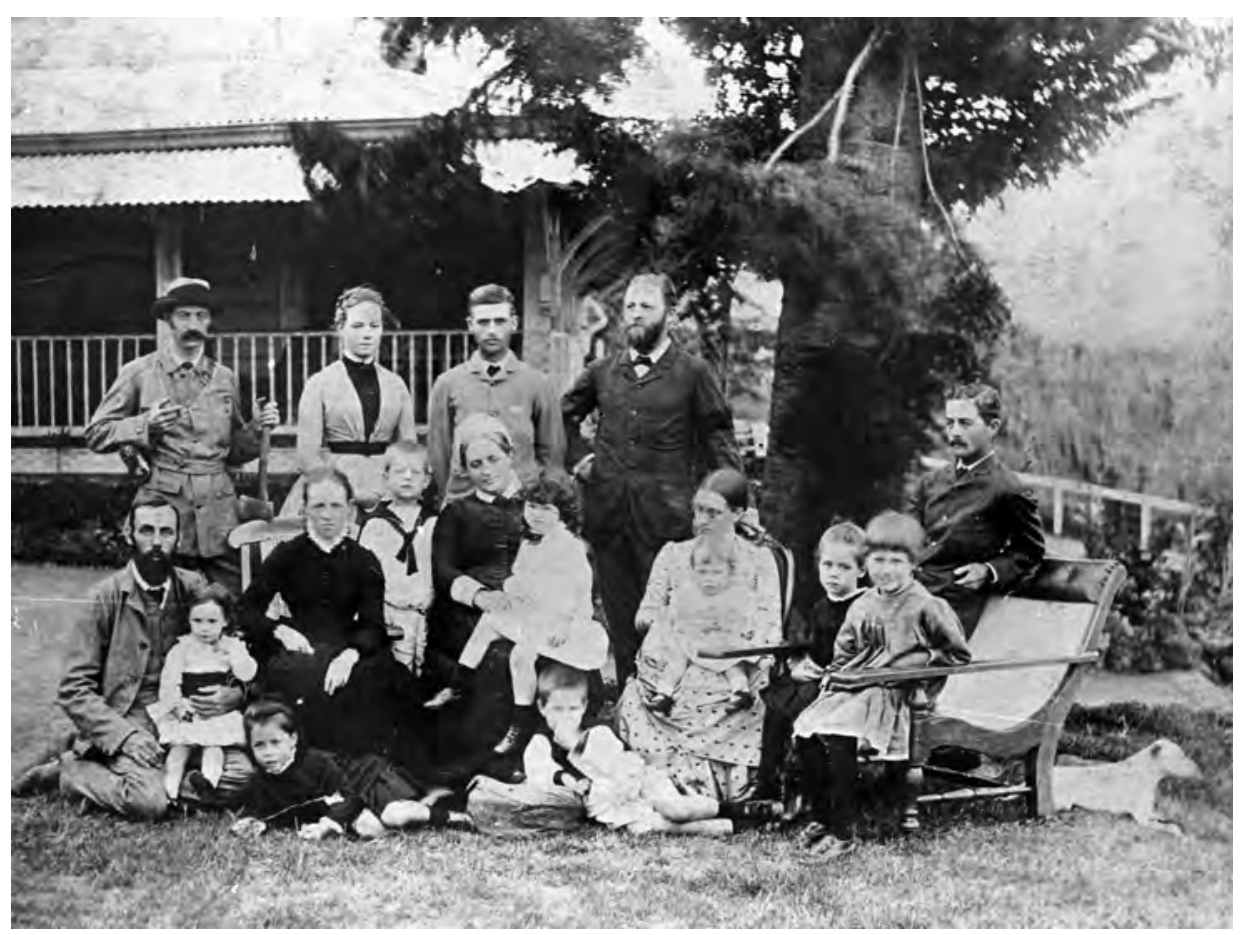

Illustration 14. McConnel family at Cressbrook station, c. 1887.

Source: John Oxley Library, State Library of Queensland.

From the early 1870s, Cressbrook was in the hands of her eldest son, $\mathrm{J} \mathrm{H}$ (Harry) McConnel, described as having continued 'most excellently the work of settlement and development begun by his father'. Like McConnel senior, he had assisted both his workers and the progress of the Esk region, including promoting the extension of the railway line to the township of Toogoolawah. ${ }^{74}$

Her other surviving sons - David Rose, Eric Walter and Edward John- together with Mary Macleod Banks, ran Cressbrook in partnership with Harry from 1873. Katharine Rose (born in 1855) married Henry Plantagenet Somerset, who was a member of the Queensland Legislative Assembly. Two of Mary and David's sons had died in infancy. Mary died in London on her eighty-sixth birthday in 1910; she and her husband are buried in Ipswich cemetery. 


\section{Conclusion}

Mary McConnel neatly fits the stereotype of M E McGuire's 'Good Fella Missus' an emigrant gentlewoman, a pioneer's wife, a kind mistress, a motherly figure who tends the sick and a 'literary woman enshrining herself in a position of benevolence and authority in race relations'. A first generation 'colonial mother', Mary also meets McGuire's description of a 'missionary seeking salvation for her black brethren'.$^{75}$ Secure in her identity as the wife of a wealthy pastoralist, she strove to help people she viewed as less fortunate than herself. She was a 'good' woman, with the 'best of intentions'.

Operating within the clutch of her paternalistic and evangelical impulses to improve the Aboriginal people, what chance did Mary have of representing Indigenous people, unless in terms of their religious and civilising journey? Although her text portrays Indigenous Australians as pawns to be moulded into her idea of a colonised world, Mary represents strong Indigenous women, who emerge beyond her confined expectations to reveal their own feelings and aspirations. While Mary's anecdotes serve to entertain, the fact remains that the Indigenous women's expressions of authority and identity were too strong to ignore.

Mary's attempts to fragment Indigenous tribal life were not successful. The white man's civilisation held no charm for the Aborigines. Even Alpin tired of Mary's experiment and returned to his people after nine of his formative years living in Britain. Mary reported her failure without malice or judgment. Looking back towards the end of her life, she still held fast to her views, always hoping, and advocating that, 'A generation or two of wise, kind treatment would make a great change in [Aborigines], but there were many hindrances, and the tribes would need to be broken up'.$^{76}$

The portrayals of strong Dungibara women inform us that they were not the passive victims or mere onlookers to a changed future. While striving to maintain their identity, they were also contributing to the ongoing future of a developing pastoral property. By repeating Long Kitty's sardonic reaction to Mary's civilising techniques and her statement of proud authority over her land, Mary highlighted the Aboriginal woman's strength of racial identity. Although Mary was happy to incorporate these reflections into her memoirs, as a British coloniser she was unable to accept them.

75 Successive McConnel women also comply with McGuire's hypotheses: Mary Banks as the second generation 'Australia's daughter' whose 'girlhood friends were Aborigines'; and anthropologist Ursula McConnel-J H McConnel's fifth daughter — as the third generation 'modern urban woman of the twentieth century who ventures into unknown Australia as writer, artist or anthropologist', McGuire 1990: 124, 149.

76 McConnel, Memories, 1905: 44. 
In spite of Mary McConnel's superior stance, dictated by her race, class and religion, like Emily Cowl, she recorded Indigenous women and girls' reaction to British fashion and custom, possibly as a literary technique to lighten the tone of her memoir and to amuse her readers. In doing so, both women have contributed to the historical record valuable instances of Indigenous humanity and authority. Mary's representations offer another perspective of Indigenous strength to counteract the often bleak story of colonisation. 


\section{Australian-born Settler- Rose Scott Cowen: Acknowledging Indigenous Humanity and Integrity}

'the white man is black in his character, and the black man is white'

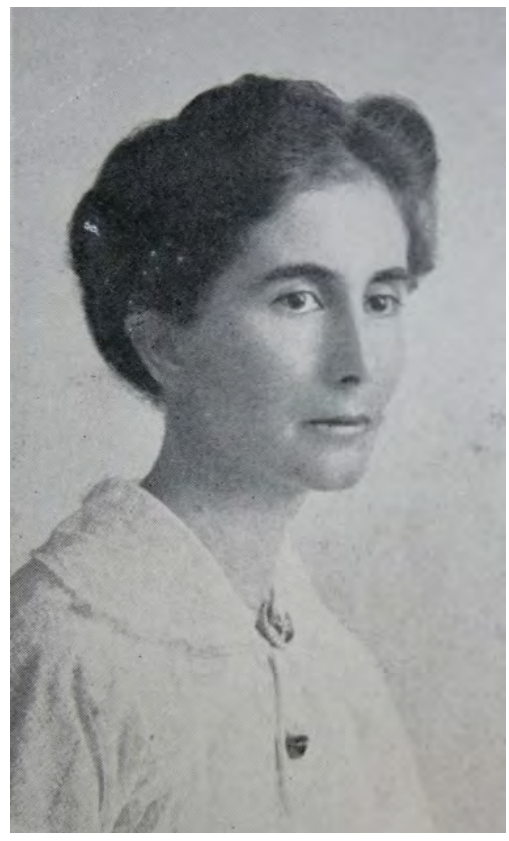

Illustration 15. Rose Scott Cowen.

Source: Frontispiece, Rose Scott Cowen, Crossing Dry Creeks: 1879 to 1919, The Wentworth Press, Sydney, 1961. 


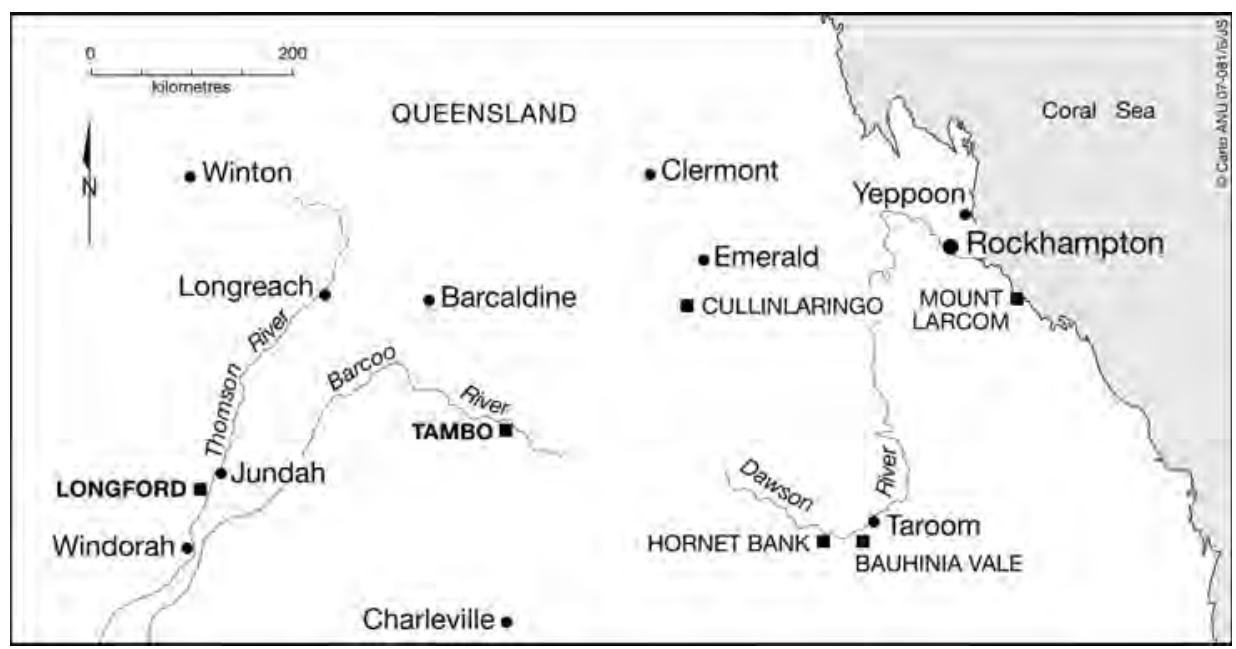

Map 7. Rose Scott Cowen. Central Queensland localities west of Rockhampton in the vicinity of the Dawson, Barcoo and Thomson rivers.

Source: CartoGIS, College of Asia and the Pacific, ANU.

Rose Scott Cowen lived in outback Queensland for most of her life and recalled her knowledge of Indigenous people candidly and directly. In 1961, the year in which she turned 82, The Wentworth Press, Sydney, published her Crossing Dry Creeks: 1879 to 1919, a 190-page autobiography of unstructured, sometimes repetitious, anecdotal prose, which fitted the publisher's ethos of supporting Australian authors (many of them women) writing on literary, historical or biographical subjects.

The metaphor in the title came from western Queensland imagery of the disappointment, even threat to life, when a thirsty traveller came to a dry creekbed that he or she had confidently expected would hold water. Having no option but to cross the dry creek, the traveller would have to continue on the journey in the hope of finding water at the next crossing. As Rose Cowen explains in her prologue, 'Crossing dry creeks' came to signify 'every danger, every close shave; every physical and economic crisis' and all the droughts, floods, toil and hardship that she had survived in outback Queensland. Marie Mahood in The Last Dry Creek describes it as 'survival of any major unexpected challenge' or 'to tackle and overcome an extreme challenge in one's life' ${ }^{2}$ Rose felt that the title encapsulated the trials in her life.

Rose Cowen's motive in writing her memoir is unclear. She seemed to enjoy writing and was keen to record her history; she submitted manuscripts on her

2 Mahood 2005: vii; Mahood 2002: xii. 
experiences and on her family history to Australian repositories ${ }^{3}$ and annotated with names and historical data the Scott and Townsend families' studio portraits, housed in the State Library of New South Wales. In 1964 she offered her biographical notes on the Scott family, together with some correspondence dated 1856, to the Mitchell Library for photocopying. ${ }^{4}$ In Crossing Dry Creeks, which she wrote when she was 'within sight of the Styx', she recalls the 'dangers and difficulties' of colonial and early twentieth-century life in rural Queensland. Her perspective of Aborigines in the late nineteenth and early twentieth centuries reveals a changing perception that went hand in hand with a loosening of British class attitudes.

\section{Illustrious pedigree}

Rose was born Annie Rose Scott Hamilton on 24 April 1879 at Tambo station, a 49 square mile $\left(78.4 \mathrm{~km}^{2}\right)$ property, situated on the Barcoo River, 200 kilometres north of Charleville and 950 kilometres north-west of Brisbane. She was the eldest of six surviving children ${ }^{5}$ of Alice, born Scott, and Terrick Alfred Hamilton and lived a carefree, outdoor life alongside people of the Wadjalang tribe.

\footnotetext{
3 The MSS include 'Across Dry Creek Beds' (catalogued as 'Memoir'), 1967, John Oxley Library, Brisbane, OM. 71-23; 'Recollections of a bush woman, 1879 to 1900', n.d., N9, Noel Butlin Archives; 'Details of my Family History', Newcastle and Region Public Library, Vertical files, 'S'; 'Notes of Reminiscences of Early Days on the Barcoo River', cited in L'Estrange 1996: 98. Rose also refers to her 'Dawson Days'; and a poem of the murder of Welford and his men (as told to her by 'Minnie') in the 'Aborigines Section of the University of Queensland', Cowen, Crossing Dry Creeks, 1961:112, 183.

4 'Scott family: mainly studio portraits of the Scott and Townsend families, ca. 1864-1886', State Library of NSW, Sydney, PXB 276; 'Scott family-papers, mainly being biographical notes on Helenus Scott's family, 1833-1964', SLNSW, MSS FM3/693.

5 Morning Bulletin, Rockhampton, 3 August 1903: 6.
} 


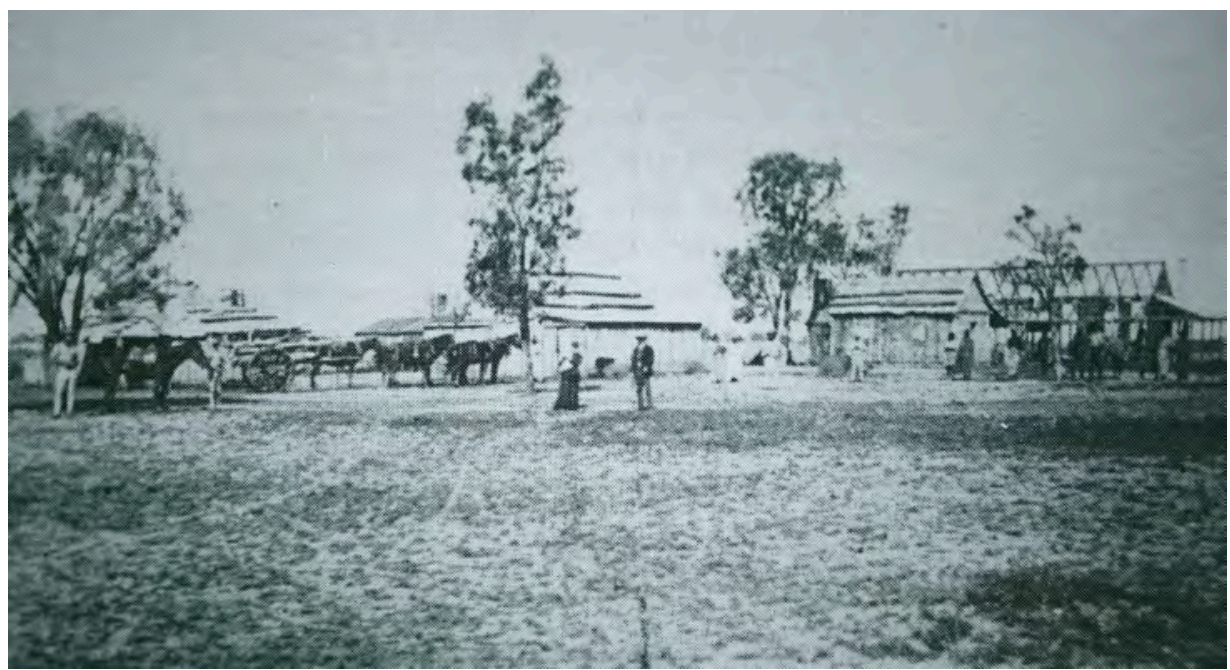

Illustration 16. Tambo Station 1880. Note Wadjalang people at right of photo.

Source: Jan L'Estrange, Belle of the Barcoo: Tambo - Geesis of Queensland's Central West, published by author, Tambo, 1996.

Rose's mother's family was associated with colonial culture and the arts. Rose was the niece of Rose Scott, the feminist and social reformer, after whom she was named. Her grandmother was Sarah Scott (born Rusden), the 'accomplished linguist and scholar', ${ }^{6}$ and her great-uncle, Robert Scott - described as a man of 'superior education and acquirements' ${ }^{\text {— }}$ - had made his property Glendon, on the Hunter River near Singleton, New South Wales, a cultural hub for artists, scientists, explorers and clergy. During trips to Sydney, Rose visited Lynton in Jersey Road, Woollahra, where Rose Scott and her mother lived, and described it as a place 'packed with books and all sorts of delightful pictures and old world things'. Rose Scott's weekly salon, where 'all the wit and brains' met, attracted writers, artists, lawyers, doctors, clergymen, scientists, politicians, naval and military men and actors and actresses. Rose and Alice Scott's cousin, book collector and benefactor, David Scott Mitchell, had bequeathed to the Public Library of New South Wales his collection of books and maps. ${ }^{8}$

Members of Rose's father's family were landholders, active in pastoral affairs, and with a connection to the English aristocracy. Terrick Hamilton's greatgrandfather, Sir Walter Farquhar, had been the physician to the Prince of Wales,

6 Judith Allen, 'Scott, Rose (1847-1925)', ADB, NCB, ANU, http://adb.anu.edu.au/biography/scottrose-8370/text14689, accessed 18 July 2013.

7 Nancy Gray, 'Scott, Robert (1799-1844)', $A D B$, NCB, ANU, http://adb.anu.edu.au/biography/scottrobert-2642/text3673, accessed 19 July 2013.

8 Cowen, Crossing Dry Creeks, 1961: 89, 27; G D Richardson, 'Mitchell, David Scott (1836-1907)', ADB, NCB, ANU, http://adb.anu.edu.au/biography/mitchell-david-scott-4210/text6781, accessed 18 July 2013. 
later King George IV, and the Prime Minister William Pitt the Younger, and for this work was awarded the title of 1st Baronet in 1796. Sir Walter had been a patron of John Macarthur, whose family maintained a friendship with the Hamiltons in Queensland. One of Terrick's oldest and closest friends, whom he had known at Eton was the somewhat notorious George Victor Drogo Montagu, Viscount Mandeville, the 8th Duke of Manchester. The duke had visited Tambo, as had New South Wales Colonial Secretary, Sir Edward Deas Thomson; Sir Francis Murphy, a landholder on the Ovens River, former member of the Victorian Legislative Council and, later, Speaker of the Legislative Assembly; the Hon. John Stevenson and the Hon. Boyd Dunlop Morehead, pastoralist and Queensland premier from 1888 to $1890 .{ }^{9}$ In spite of these connections, Rose maintained a down-to-earth attitude towards everyone she met.

Both Rose's grandfathers were pioneering landholders. Her paternal grandfather, Edward William Terrick Hamilton, had jointly purchased in 1839 (with his cousin, Henry George Hamilton, and a friend, George Clive), Collaroy, near Cassilis, 200 kilometres north-west of Newcastle. He returned to live in Britain in 1855 and from 1857 to 1898 he was governor of the Australian Agricultural Co. ${ }^{10}$ Rose's maternal grandfather, Helenus Scott, had settled in about 1822 with his brother, Robert, on the combined large land grant of Glendon, 50 kilometres north-west of Newcastle. Through her Scott connections, Rose was related to the prominent Hunter Valley pastoral families of the Merewethers, Selwyns, Shaws, Mitchells, Ranclauds and Wallaces. ${ }^{11}$

Clergymen peppered Rose's pedigree on both sides of her family. These included two of her great-grandfathers - the Rev'd George Keylock Rusden, first minister of St Peter's Church of England, East Maitland, and the Archdeacon of Taunton and Rector of Loughton, Essex, Venerable Anthony Hamilton, who was also consultant to the Colonial Office on colonial ecclesiastical appointments; his father and his mother's father were also clergymen. Rose's paternal great-uncle, Walter Kerr Hamilton, was the Bishop of Salisbury from 1854-69. ${ }^{12}$

9 Cowen, Crossing Dry Creeks, 1961: 10, 60; Darryl Lundy, The Peerage, Person Page 13589, No. 135884 and No. 27474, http://www.thepeerage.com; M E Osborne, 'Thomson, Sir Edward Deas (1800-1879)', ADB, NCB, ANU, http://adb.anu.edu.au/biography/thomson-sir-edward-deas-2732/text3855; accessed 4 August 2013; Margot Beever, 'Murphy, Sir Francis (1809-1891)', ADB, NCB, ANU, http://adb.anu.edu.au/biography/ murphy-sir-francis-4275/text6913, accessed 24 July 2014; Parliament of Victoria website, www.parliament. vic.gov.au; 'Morehead, Boyd Dunlop (1843-1905)', ADB, NCB, ANU, http://adb.anu.edu.au/biography/ morehead-boyd-dunlop-4240/text6845, accessed 4 August 2013.

10 J R Robertson, 'Hamilton, Edward William Terrick (1809-1898)', ADB, NCB, ANU, http://adb.anu.edu. au/biography/hamilton-edward-william-terrick-455/text5801, accessed 4 August 2013.

11 Nancy Gray, 'Scott, Helenus (1802-1879)', ADB, NCB, ANU, http://adb.anu.edu.au/biography/scotthelenus-2851/text3673, accessed 4 August 2013; 'Descendant of Pioneers Dies', Newcastle Mining Herald and Miners' Advocate, 24 July 1971: 4.

12 Newcastle Morning Herald, 24 July 1971: 4; Mennell 1892: 211; Personal communication, Pennie Pemberton, Noel Butlin Archives Centre, ANU; Robertson, 'Hamilton, Edward William Terrick', $A D B, \mathrm{NCB}$, ANU, http://adb.anu.edu.au/biography/hamilton-edward-william-terrick-455/text5801, accessed 4 August 2013; Darryl Lundy, The Peerage, Nos 135882, 37368, 135885, http://www.thepeerage.com. 


\section{'We should not be snobbish'}

Although Rose's middle-class credentials were impeccable, two factors contributed to her dispensing with class-driven attitudes. One was her father's exhortation not to be snobbish, and the other was her own long experience, living among the people of outback Queensland.

Terrick Hamilton had been sent to the Australian colonies by his father because of high-spirited behaviour when a student at Eton and Cambridge. He first worked as a jackeroo at Warrah station, near Quirindi, New South Wales - a property of the Australian Agricultural Co. In February 1878 he married Alice Scott, who was from the nearby Glendon station and that year he became the manager of the combined Tambo and adjacent 44 square mile $\left(70.4 \mathrm{~km}^{2}\right) \mathrm{Mt}$ Pleasant runs, of which he was a part-owner. With the assistance of the Bank of Australasia (of which his father, Edward Hamilton, was chairman), Terrick became the sole owner in 1890 .

As the eldest child, Rose became her father's 'inseparable companion' and identified with his feelings, stories and tasks. She rode daily with him, mustering the sheep, cattle and horses, going to check the artesian bores on the outermost paddocks and joining him at his hobby of blacksmithing. From an early age she helped with the station accounts and the stores, and in the press copying of the business letters. Accompanying Terrick on long buggy rides between sparsely situated outback towns, she listened to the stories of his youthful wild escapades, of his 'prim old aunts' and his stern father who disapproved of his passion for horses. ${ }^{13}$

Rose wrote of her father that:

The Boss was very definite that we should not be snobbish and that we should regard the men and the servants as fellow human beings which I think was the foundation of my deep interest in everybody and their life stories and problems. ${ }^{14}$

13 Cowen, Crossing Dry Creeks, 1961: 40.

14 Cowen, Crossing Dry Creeks, 1961: 67. 


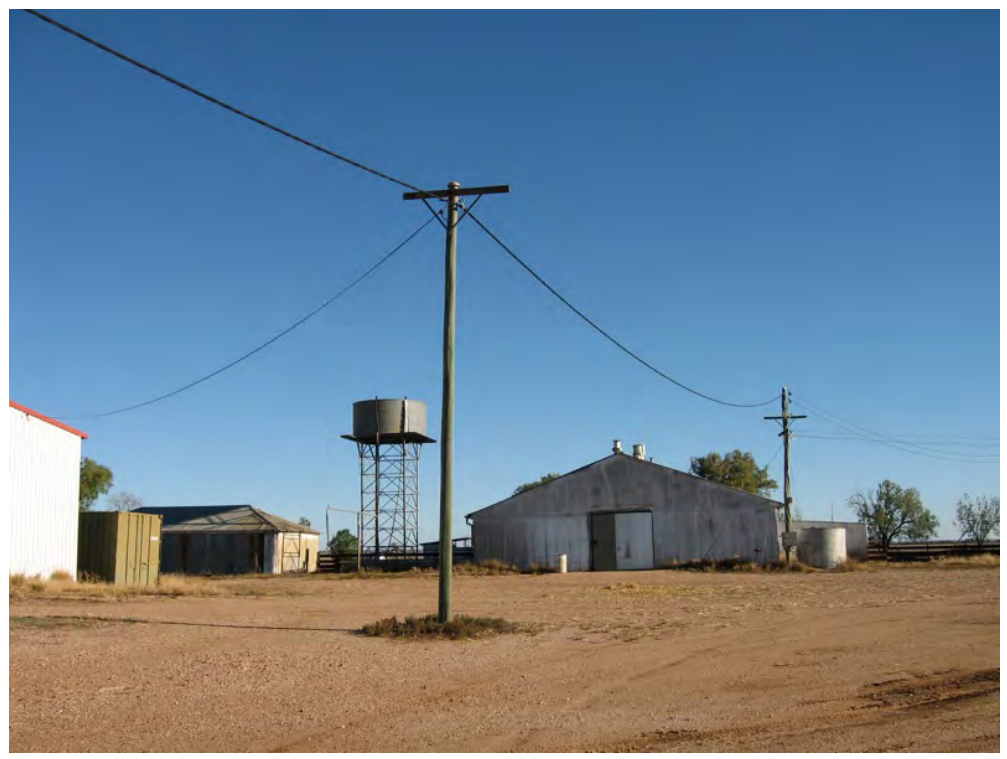

Illustration 17. Farm buildings, Tambo station.

Source: Barbara Dawson, June 2006.

She cites her father's generosity in his payment to his workers and his assistance to a Tambo overseer with tools and equipment when he took up his own selection. During the 1891 shearers' strike - which started at Barcaldine, 200 kilometres north of Tambo - the Hamiltons' shearing shed was left free of assault when others in the area were burned down. Rose attributed this reprieve to her father's high standing among the working men. When a large bushfire broke out, striking unionists returned voluntarily to Tambo to help fight it. By contrast, grassfires had been started on the nearby Minnie Downs and Langlo Downs. ${ }^{15}$

When Rose visited her grandfather and aunts at Charters, Sunningdale, eight kilometres south of Windsor, for an English 'coming out' year in 1895, when she was 15 years old, she saw at close range the 'snobbishness of ... class'. She found the formal atmosphere in the house to be stultifying and she hated the pomp and ceremony. At dinner parties 'the order of precedence was so strict' with the most important person offered her grandfather's arm, and then the decision made as to 'who should follow whom'. Edward Hamilton, despite his colonial experience, embraced British attitudes of class and status, being described as a man who considered himself superior to 'members of the middle class and the lower orders'. In this 'awful stiff atmosphere', Rose 'ached and ached for the

15 Lilley 1977: 124. 
sunshine and the freedom of my bush home'. Dismissing any notion of a pretty English landscape, she considered the trees to be 'as prim and smug and correct as [the] people'. ${ }^{16}$

While in England Rose met aristocracy and foreign royalty, but was impressed by a person's character, not by his or her social position. Sir Donald Smith (Lord Strathcona), a Canadian, who co-founded the Canadian Pacific Railway, fitted her criterion. He had 'no social graces but a very impressive sincerity'. Rose's cousin was a goddaughter of Queen Victoria, but Rose was relieved when a proposal that she be 'presented at Court and have a London season' was quashed because Queen Victoria 'objected to having anyone younger [than 18] presented to her' $^{\prime}{ }^{17}$

Rose wrote iconoclastically of the English churches and cathedrals, observing that:

the thing that impressed me most ... was the dark damp musty smell which I was amazed to find the English did not seem to notice. They seemed to have absorbed through all the years the odor of unwashed bodies and feet, and the dead who were in vaults under their floors or clustered thickly in the yards outside their walls. It certainly added to the awe! Especially if one added "ful" to the word. ${ }^{18}$

\section{'My beloved West'}

After her marriage in 1900 to the grazier, William Cowen, Rose and Bill had brief forays into mixed farming near Clifton in the Darling Downs and at Bauhinia Vale on the Dawson River near Taroom. However, they were 'yearning for the West', and so in 1907 they moved to Longford, a sheep and cattle station 25 kilometres south of Jundah on the Thomson River, in the Channel Country. In western Queensland Rose lived among people who were striving to cope with the harsh climate and often grappling with their own demons.

16 Cowen, Crossing Dry Creeks, 1961: 76, 71-73; Robertson, 'Hamilton, Edward William Terrick', ADB entry, cf. above.

17 Cowen, Crossing Dry Creeks, 1961: 73, 77.

18 Cowen, Crossing Dry Creeks, 1961: 76. 


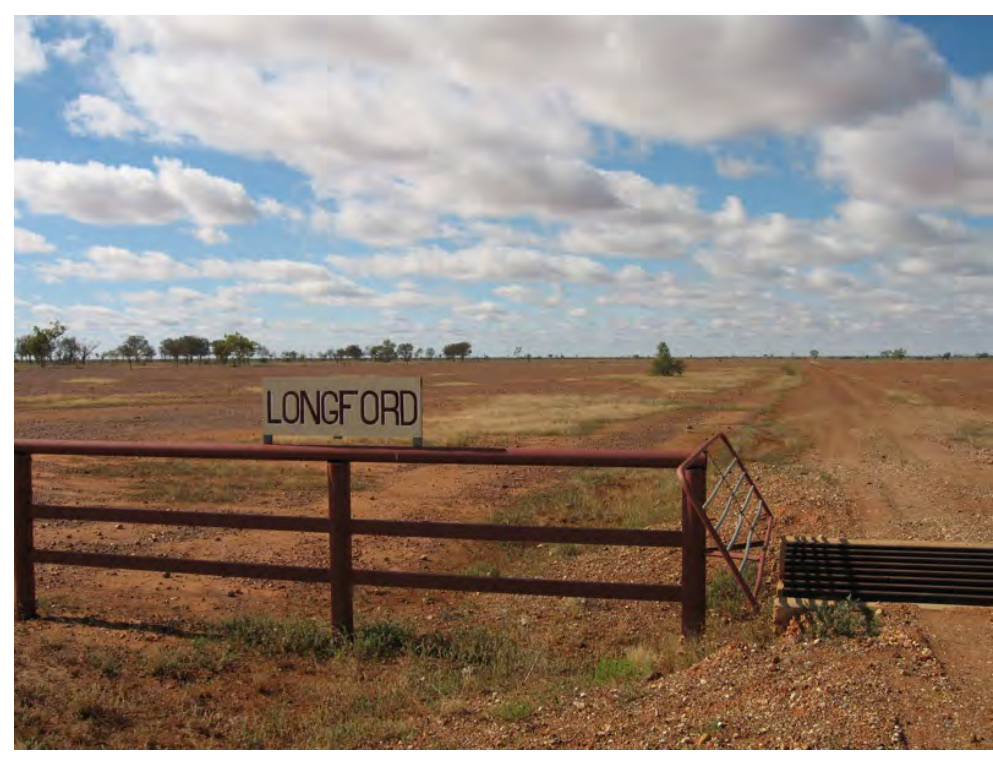

\section{Illustration 18. 'My beloved West'.}

Source: Barbara Dawson, June 2006.

Rose explained the effect of hardship and discomfort on the local inhabitants:

There were more droughts than good seasons, and the worry and misery of them is indelibly imprinted on my memory. The great heat when the hot wind seemed to sear one's skin and such a dry parching wind that one's lips cracked and one felt that a smile would be to split the skin of one's cheeks like perished parchment. Often the hot wind would come in savage gusts that made one instinctively feel that the Devil was opening and shutting the lid of Hell in order to get some fresh heat from the blazing sun ... It was hard to think aright and only those who had resources of the mind or were creatures of no intellect ... could endure years of it without becoming adversely affected. That is why so many people developed eccentricities in the Outback. ${ }^{19}$

She described the prevalence of misfits and eccentrics, attracted to the region:

The Outback has so many of these failures, the wrecks that drift away from the civilization which has no time for the vice that is found out (unless it has wealth and position to gild it). They gradually work back 
and back into the Never-Never amongst a community who, living a hard life close to nature and therefore being more understanding and tolerant, accepts them for the good which is still in them. ${ }^{20}$

In these conditions, social class was irrelevant. Resilience, the ability to work hard, and moral integrity and honesty were the character traits esteemed by Rose, as people endured the heat, isolation and, as she reported, 'sometimes the shortage of food when we were cut off from communication from the outer world'. ${ }^{21}$ As a skilled horsewoman, who had won prizes at horse shows in Charleville, Roma and Toowoomba in the late 1890s and had gained the reputation as one of the best lady side-saddle riders in Australia, ${ }^{22}$ she also highly regarded people that showed kindness to horses and who handled them well. She accepted with equanimity the prevalence of drunkenness and swearing, which she saw as normal behaviour among her outback acquaintances, merely writing down the 'blank' and 'blankety' of unpublishable obscenities. She noted that:

The men of that day were a wild roistering crowd, and what would not be permitted by public opinion today, was in order then. Men drank a lot more and there were always demi-johns of whisky and rum in the station homesteads. Owners and men drank heavily. I can remember that the strictly sober man was a remarkable person, just as now the drunkard is the one who is specially noticed. Men worked very hard in those days and they needed a "pick-me-up" in the evenings, but when droughts and bad times were in control and men saw no way in which they could save their stock, and when they rode out on the run and saw them dying or dead in their thousands, they turned to the whisky bottle or wild excesses to give their tortured minds some relief. ${ }^{23}$

In a particular example of the type of dishonesty and hypocrisy she abhorred, Rose cited an unscrupulous Tambo publican who later became a warden at a Darling Downs church. Rose recognised him 'in an odor of sanctity' but remembered that, as a publican at Tambo, he had poisoned the alcohol and robbed 'simple trusting men' on his way to wealth. Repulsed, she immediately turned away from that church. ${ }^{24}$

Rose assessed all ministers of religion by the same criteria that she applied to other people in the outback. She referred to a 'fool of a clergyman' who allowed his two buggy horses to be drowned in a local waterhole. Her general opinion of them was that:

\footnotetext{
Cowen, Crossing Dry Creeks, 1961: 130.

Cowen, Crossing Dry Creeks, 1961: 164.

Lilley 1973: 60, fn. 2.

Cowen, Crossing Dry Creeks, 1961: 14-15.

Cowen, Crossing Dry Creeks, 1961: 127.
} 
the clergy of that day [did not make] much headway with the Bush people. They were so very English, and so very patronising to the "heathen bush people" whom of course they believed had all descended from convicts and must be saved from the eternal damnation that was certainly the lot of all the convicts, men who in many cases had been transported for such paltry crimes as stealing a loaf of bread or poaching - my Father and Grandfathers all said these men on the whole were fine fellows and good and loyal workers. ${ }^{25}$

Her regard for an ability to work hard cut across divisions of gender, class or race, as she applied her character standards to the 'black Malay' or Chinese cooks, the Chinese gardeners and the many Irish, Scottish and English immigrants on Tambo. She sympathised with the 'Remittance Men' at Tambo in the 1880s, describing them as well-educated and 'fine fellows', with only the one fault'drink'; she censured English class attitudes that had motivated the young men's expulsion to Australia after they had disgraced their families with 'minor peccadilloes', and she directed her most scathing attack onto the clergymen that had displayed a 'narrow respectability beyond forgiveness' ${ }^{26}$ towards their sons. On the other hand, she praised the kind, law-abiding, 'hard-working' German families, whom she had met both in the Darling Downs and near Longford, and among whom,

the women worked even harder than the men, and made use of everything, often turning out really wonderful needlework, knitting and crochet, making all their own jams, preserves and pickles and growing all their own vegetables. They deserved to get on and they did. ${ }^{27}$

Rose endured 11 years of heat, dust and isolation but, because of unbearably high temperatures, spent only two summers at Longford. Hard working and wiry, she became a self-confessed 'bushie' and a 'godless creature'. ${ }^{28}$ As a person's gender, social position or race were irrelevant to a capacity to cope, Rose's Indigenous companions were among those she most admired during her years in the Channel Country.

\section{Ambivalent attitude to Aborigines}

Rose Cowen's representation of Aborigines falls into two categories. One relates to her father's stories, the other stems from her own experience. As the child and grandchild of pastoral pioneers, she adopted and accepted the white man's

25 Cowen, Crossing Dry Creeks, 1961: 94.

26 Cowen, Crossing Dry Creeks, 1961: 130-131.

27 Cowen, Crossing Dry Creeks, 1961: 83.

28 Cowen, Crossing Dry Creeks, 1961: 123. 
attitudes and actions towards the Indigenous owners of the land. She rationalised settler violence, repeating the concept of Karl Lumholtz, a Norwegian scientist, who lived in Queensland during the 1880s, that 'it is an immutable law of nature that the strong will prey upon the weak' ${ }^{29}$

The question of whether the original inhabitants were justified in trying to destroy the invader is an age old one, going back beyond the occupation of Judea and if one condemns the white race for taking Australia from the aborigine one must go on to a condemnation of every race in the world, including the Danes and Norwegians and Saxons and Normans, Ghengis Khan and Atilla and Alexander who wept because there were no more worlds to conquer - Australia being then a terra incognita. It seems a law of nature that reptile, bird and beast and man must all prey on one another. ${ }^{30}$

She supported the colonists' argument for retribution:

People today may be horrified by the merciless punishment meted out to the blacks for murder but they should remember that the blacks were very numerous in those days and the whites very few and widely scattered. Therefore they used the black's [sic] own law of the death punishment for a death - which with the aborigines extended to the whole tribe by the other tribe - and their policy had to be adopted by the whites as the only one they would really understand. Only so could the opening up of the country be safe and successful. I noticed that the Dawson blacks were much better grown and developed than those I had known in my childhood at Tambo and they seemed inclined to be "cheeky" and had the reputation of being treacherous. ${ }^{31}$

Queensland's early settlement has been referred to as 'the most troublesome frontier story of all the Australian colonies', ${ }^{2}$ and Rose was privy to some of that history. She knew the story of how previous owners of Tambo had fired into the midst of the local Wadjalang people with shotguns, killing and wounding 'a good many'. After a 'wild corroboree', the Aborigines had come 'swarming' up to the homestead and the owners, out-numbered, and not knowing their intentions, 'made sure of getting in first'. According to Rose,

It had a very salutary effect as the whole tribe decamped and were away for many months before they began to drift back in ones and twos. ${ }^{33}$

29 Reynolds 1996 [1987]: 123.

30 Cowen, Crossing Dry Creeks, 1961: 68.

31 Cowen, Crossing Dry Creeks, 1961: 118.

32 Evans 2004: 160.

33 Cowen, Crossing Dry Creeks, 1961: 2. 
Her father had told her that the Aborigines on Warrah, where he had been a jackaroo, were 'bad and numerous' and she repeated the tale without qualification.

She knew other stories from her father:

The Boss told me that in the 70's when he first went to Tambo, there was a very large and sometimes cheeky tribe and therefore the Police, to ensure that they did not get out of hand, would select the cheekiest young men and take them out into the gidyea scrub at the back of the town - ostensibly horse hunting, but they were never seen again and of course the tribe guessed what had happened. People to-day may be shocked at these methods of making a country peaceable but they should remember that there were very few whites in comparison with the numerous aborigines and the wives of those whites, women and children, had to be protected against attack and murder whilst the men folk were out on the runs looking after their stock, and these killings which were few (unless in reprisals as in the case of the Cullinlaringo and Hornet Bank massacres by the aborigines) served through fear of the white man's swift punishment to make the country safe for settlement ... I admit that sometimes the reprisals went far beyond justice and developed into plain murder as was sometimes the case with the native police of whom some terrible stories are told. ${ }^{34}$

She herself could identify a site at Juanda on the Dawson River where Aborigines had been driven into a waterhole and shot, as part of reprisals after the murders at Hornet Bank, where members of the Fraser family had been killed. According to Rose, Terrick Hamilton had joined the raids on Aborigines that followed the 1861 Cullinlaringo murders of 19 settlers near Emerald, in central Queensland.

Again, in the 1880s, some Wadjalang men had crept up to Tambo homestead to steal alcohol after their allotted supply had been consumed. Hamilton and two workmen took firearms and,

Just to show them that the folks in the house would stand no nonsense, the Boss fired a couple of rifle shots in the direction of the noise there was instantaneous silence and suddenly [one of the workers] remembered that his race horse was somewhere about those bushes and was frantic lest the stray bullets should have found him. In the morning the Boss went down to the camp with the shot gun and shot every one

34 Cowen, Crossing Dry Creeks, 1961: 67-68. Compared with Rose Cowen's somewhat sanguine view, Judith Wright - whose father also took part in the brutal forces of colonisation - mourned Aboriginal deaths and dispossession, Wright 2004, 1991. 
of the dogs to show the aborigines that he was ready to shoot them if necessary. The effect was most salutary, the blacks cleared out and never came back. ${ }^{35}$

Rose's most vivid memories of the Wadjalang people on Tambo were of her nurse 'Dinah', who with her husband, 'old Harry', were 'king' and 'queen' of their tribe. Because of her adventurous spirit (even as a baby), Rose credits her survival and nurturing to the efforts of Dinah. Harry had succumbed to white authority and wore, suspended on a chain around his neck, the brass plate of 'kingship' that the infant Rose liked to hit with a stick. Rose referred to Harry's 'gentleness' and 'humility', inferring that he now lived an easy life, with no mention of his former warrior past or of his lost pride and country. Of the Wadjalang like Dinah and Harry, who had decided to return to Tambo, some worked in the shearing shed as fleece pickers or carriers of the wool from the classing table to the bales for pressing.

\section{'The white man is black in his character, and the black man is white'}

In the Channel Country, Rose presented a different view of Aborigines, born of her own experiences at Longford. Applying her test of character equally to the white and black people she knew, she depicted settler laziness, deceit and dishonesty; alcoholic women, drunken doctors, female cooks who were 'very loose in their morals'; and 'bad, flashy' lady helps, one of whom murdered her newborn illegitimate child in the Longford homestead. Another example of white 'depravity' was of a cruel station owner, who stamped on Aborigines' toes to make them sing in church. On the other hand, she wrote of the help that Aboriginal youths gave to settlers, sometimes as expert horse groomers. She cited the story of an Indigenous lad, who saved the life of a landholder suffering from scurvy by 'boiling a plant and giving him the green mess and the water'. When a white man whose own 'savagery was inflamed by doped grog' left his daughter to die in the bush near Charleville after she had drunk her water bag dry, Rose told of how Aborigines 'succoured' the child and 'delivered her safely back at Windorah' over 300 kilometres away. ${ }^{36}$

In reference to Aboriginal laws which she deemed 'much more strict - and moral' than the white man's, Rose acknowledged her respect for the taboo

35 Cowen, Crossing Dry Creeks, 1961: 67

36 Cowen, Crossing Dry Creeks, 1961: 133-134, 81, 85, 180. 
which prevented an Indigenous woman from even looking at a visiting tribal 'brother'. This behaviour applied to the law that forbade sexual relationship with someone from the same clan. Rose added:

In the early days in attacks on white settlers, the women were killed with their men by the aborigines but there was none of the wicked raping that was practised by the natives of other countries. ${ }^{37}$

Rose applauded the Indigenous custom of the father leaving mother and child for about a year after childbirth 'to give the baby a chance', the community sharing their food with the new mother. Reflecting that this was 'rather an example to the whites', she added: 'Indeed from what I knew of the morals of the people in ... bush townships I was often shamed to think that ... the aborigines in their wild state ... were far more virtuous' ${ }^{38}$ She declaimed that:

really one feels that the white man is black in his character, and the black man is white, for the aborigine obeys his tribal laws and the white man flouts his and seeks every opportunity to secretly break them. ${ }^{39}$

Her acceptance of individuals irrespective of their race meant that she introduced people into her narrative by describing their temperament or character before identifying their racial heritage. For example, a 'joyous youngster [whom we] all liked ... immensely, he was so happy natured, so unaffected ... our ray of sunshine' was 'half Indian'. She similarly identified 'George' (a part-Aborigine) as a 'fine strapping big man [employed] to break horses', with one failing, 'drink', a trait that was common to 'most of the fine men in the bush'. ${ }^{40}$

Allegiance to character, not race, saw her supporting George, when a white cook who was a staunch unionist, dedicated to the union's dictum of 'white Australia', refused George's entry into the Longford kitchen. George went to the Cowens with his concerns that, if excluded from the other working men, he was likely to lose his own union ticket. Rose chose to support George, reporting that:

I had to explain all this to [the cook], adding with a touch of malice "So you see Connors, he is your brother unionist". Connors mopped his face with the tea towel he was using to dry up and exclaimed: "My God, to

37 Cowen, Crossing Dry Creeks, 1961: 184.

38 Cowen, Crossing Dry Creeks, 1961: 184

39 Cowen, Crossing Dry Creeks, 1961: 65.

40 Cowen, Crossing Dry Creeks, 1961: 155-156. Although Indigenous soldiers are difficult to track, recent communication with Gary Oakley, Indigenous Liaison Officer, Australian War Memorial, suggests that George may have been Pte George Robert Aitken, born at Taroom, enlisting on 19 October 1917, serial no. 2367, 52nd Battalion. 
think I'd even have to put up with a nigger in my kitchen". And this was his plaint all the time the men were having their food! It speaks well for George that he never knocked him down. ${ }^{41}$

When George died as a soldier in World War I, Rose wrote that 'the West lost a really fine type of half-caste, generous, decent, honest and straight, and a splendid horseman'. Rose had acted upon George's expressed dislike for military camp life and 'all this damn saluting', by writing to the camp commandant, Colonel Flewell Smith, whom she knew, asking that George be considered for active service. George later thanked Rose for getting him 'away from the camp into the real fighting'. He died in action in France. Rose extended her identification with people of mixed racial heritage, when she added:

So often the half-caste seems to have the vices and weaknesses of both races and these are emphasised by the uncertainty of where they stand in the community - they belong to neither race; the whites looked down on them and the aborigines treated them as being outside the tribe. No wonder the poor fellows felt the injustice and became reckless, bitter and often bad. ${ }^{42}$

Rose decried the 'lordly and contemptuous attitude of the early British settlers', who could have learned about the environment from the Aborigines. Referring specifically to 1916, she wrote that:

The tragic loss of life in the Clermont flood would never have taken place had the blacks' warnings been heeded. They said "no camp here (when they saw houses being put up) big pfella flood come down, wash um away" and the same thing happened earlier in the St George districts in the early 60's. The whites would not believe [what the blacks said] so they had most if not all of their flocks and herds swept away and drowned. The aborigines were so weather wise and had such a keen sense of smell that they could smell changes in the weather or a dust storm coming long before it appeared to us, or the smell of smoke, and being such keen observers of the habits and reactions of birds and animals they knew when a dry time was setting in and made their plans accordingly, hence their survival as tribes in such a waterless land. Their knowledge of the properties of plants and trees would have been of inestimable value to the new settlers had those contemptuous whites not been so sure that the black was a "poor ignorant creature". ${ }^{43}$ 
According to Rose, European Australians were 'the products of a vaunted civilization that could not cope with the primitive in a show down with nature'. Indigenous knowledge, she argued, could have provided settlers with basic survival skills. She cited as example the Burke and Wills expeditionary disaster that occurred in country where 'the waters teemed with fish, crayfish, mussels', where there were 'succulent red pigweed', 'great flocks of birds, and the seeds of the nardoo and grass'. ${ }^{44}$

From her understanding of Indigenous people, Rose reported that while the aborigine will laugh with you [he] hates to be laughed at. So we, and those early settlers, had to learn the hard way, by trial and error and disaster what the blacks could have warned us against'. Indigenous laughter, as the Aborigines enacted 'for the rest of the tribe in mimicry and pantomime the incredible (to them) mistakes' made by the white men was, according to Rose, 'poetic justice' for the settlers' 'woeful ignorance and blunders' ${ }^{45}$

Jundah resident, B J Rayment, expressed sympathetic opinions similar to Rose's comments, sometimes using similar language. Having had Aboriginal playmates and workmates, Rayment asserted that 'there is not one per cent more bad black men than bad white men' and that '[m] ost of our condemnation of the black Australians is just an excuse to cover our rotten treatment of them'. He deplored the fact that 'we have developed this country to our own gain and to their cost of semi starvation and degradation [a fact which] is surely not right by Christian ways, but I am glad to think that at long last something worthwhile may be done for the survivors'. Deeming the British race, with its 'vaunted civilisation' as 'damned hypocritical', greedy and selfish, he added that, 'I hate to harp on these things but it is a great pity that we white people have such a superiority complex' ${ }^{46}$

Rose acknowledged the validity of Indigenous lore, writing that:

When I was a child people laughed at the aborigines for being afraid of bunyips or 'debbil debbils', refusing definitely to go near certain places - more especially permanent waterholes. They were dubbed "Silly frightened creatures". Now ... we know that their ancestors had to really fight for existence with the huge and fearsome reptiles and animals that roamed the land, and the fear was deeply implanted in their whole beings by their legends and corroborees. Now that the land is becoming more settled we are finding the fossilised remains of some of these prehistoric monsters and where scientists are groping now to

44 Cowen, Crossing Dry Creeks, 1961: 136.

45 Cowen, Crossing Dry Creeks, 1961: 135-137. Cowen repeats these sentiments on pp. 187-188.

46 Rayment c. 1971: 129, 61, 174, 168. Rayment's My Towri was contemporary with Crossing Dry Creeks. Although he published in c. 1971, Rayment wrote much of 'My Towri' in 1956. 
reconstruct those creatures and guess at their habits, the early settlers could have learnt so much at first hand from the aborigines, had they only shown their interest and sympathy. ${ }^{47}$

\section{‘My beloved' Minnie}

Rose's trials at Longford began with the homestead. This was:

a dreadful building of unpainted galvanised iron roof and walls. and the uprights were of bush timber - I barked these myself later on with a tomahawk and a butcher's knife and the loss of quite a lot of skin off my fingers. The three good sized rooms were unceiled and the cobwebs hung in festoons from the roof. The detached kitchen was also of iron throughout and had ... a kitchen range that I grew to hate with every smarting fibre of my being during the 11 years I was there. The chimneys had holes in them and when a westerly wind blew, the smoke poured into the kitchen from these holes and my eyes so often smarted and stung. It was a very small set-in range and as my husband employed a lot of men (4 jackeroos and one overseer in the house and six men in the kitchen and the two blacks in their camp) it was a fearful daily problem to get the food cooked. ${ }^{48}$

Domestic work centred on the cleaning and cooking. After the weekly dust storms 'one breathed dust, ate dust and slept in dust' and afterwards, 'dust was everywhere, in our eyes, our mouths, on our teeth, outlining our classic features on the pillow as we slept, going pouf pouf as we walked across the floors [and] on our food'. Cooking on an earthen kitchen floor in summer was 'just like standing on hot bricks'. After a storm, 'being lower than the outside, [it] would be awash' with water. Three times a day, Rose 'dish[ed] up ... 3 sets of meals simultaneously', baked 'quantities of cake' and made puddings for 'the house, the kitchen and the blacks'. Every second day, she produced 'big batches' of bread and cooked the meat from a sheep. Almost immediately after she had cooked and served the Longford breakfasts, she was required twice a week to feed coach passengers travelling between Jundah and Windorah with a meal that included lamb chops and scones. Located on the main north-south road, Longford had many other (hungry) callers, 'all unexpected'. While the arrival of the motor car helped relieve the burden of isolation, Rose deplored the fact that, unlike during the horse era, she had little time to stoke up the fire and start cooking after she saw the approaching dust of a traveller's car. ${ }^{49}$

47 Cowen, Crossing Dry Creeks, 1961: 188.

48 Cowen, Crossing Dry Creeks, 1961: 124.

49 Cowen, Crossing Dry Creeks, 1961: 135, 141, 165, 124, 185, 179. 
Rose was helped in her toil by Coorooboolka (Coorabulka) woman, 'Minnie', from the Pitta Pitta country near Boulia. Minnie and 'Tommy', an Aboriginal man from northern Queensland, had stayed on at Longford when the Cowens bought the property. After Tommy died, her second husband was 'Dick', Tommy's brother. While Minnie was seen as part of the Longford purchase agreement, her position imitated Rose's evaluation of rural wives, of whom she wrote: 'Women in the farming districts don't occupy a very high place in the masculine community-being classed usually according to their degree of usefulness with the other animals'.$^{50}$ As the two women strove together to subdue the forces and effects of climate, the divisions of race and class were virtually erased in the shared connection of gender.

Whereas white domestic workers had proved unsatisfactory, Minnie was hard working and dependable. Rose described the women's shared working arrangements:

Life was much more peaceful when I did the cooking and Minnie did the heavier work. What made the work so much harder for both of us was that the galvanised iron walls having been put up horizontally instead of perpendicularly held the dust and had to be wiped down regularly once a week. We did a room a day. I climbed up on a chair placed on a table and Minnie did the lower part. Rubbing every corrugation by hand took a long time and I remember that once at the end of the week when everything was bright and shining we had a terrific dust storm in the night and all the corrugations were filled up again with dust. I came into the dining room when Minnie was surveying the walls with a look of utter disgust on her face. "Ah! Minnie!" I moaned "wha you think?" "I tink damn" she replied with great emphasis. ${ }^{51}$

Rose relied on Minnie, likening their relationship to a friendship of mutual endeavour, leavened by humour:

I don't think I could have survived that hard life and overwork if it had not been for Minnie who was both loyal and devoted and did all the heavy work, such as the washing and ironing, sweeping, scrubbing and washing up. We were very good friends and when I found she had such a keen sense of humour we had many laughs together. ${ }^{52}$

Minnie assisted in outdoor jobs. She helped fight a bushfire-prevalent in 1918 after good rainfalls in 1917 and 1918; she joined in chasing away dingoes, gathered cow dung for Rose and her two sons to burn in kerosene tins to keep

50 Cowen, Crossing Dry Creeks, 1961: 98.

51 Cowen, Crossing Dry Creeks, 1961: 135.

52 Cowen, Crossing Dry Creeks, 1961: 124-125. 
the sandflies away, and gently watered and fed a tired, injured horse - a sure way of gaining Rose's respect. From her research of twentieth-century cattle stations in the Northern Territory, Ann McGrath found that Indigenous women often undertook the heavy jobs such as wood chopping, hauling water in drums and repairing fences. She suggests that Indigenous women consented to the menial, daily tasks required by settlers because:

Women in Aboriginal society were relied upon to provide the most regular and consistent food supply. Their role of food gathering and hunting smaller animals was more routine and required more constant application compared with men's hunting activities. ${ }^{53}$

On Longford, the two women supported and protected each other. During droughts, Bill Cowen frequently left the station in the hands of the 'ineffectual' overseer and Rose, while he camped with his jackeroos on a distant paddock or checked on the sheep that had been sent out to feed along the roads. Rose then had to cope with the lambs and ewes and often workers, such as scrubcutters. Sometimes she was left alone to manage Longford without the men. On these occasions, she wielded her revolver and shotgun whenever drunk white men approached the station, while Minnie's defence were her two ferocious halfbred bull-dog cattle dogs that she used against unwanted visitors when the women were alone. When advised to keep away from a coach passenger visiting Longford, Rose and Minnie both retired to the homestead and watched events together through the window.

During racial verbal abuse of Minnie and Dick by Longford's American horse driver, Rose sided with the Aborigines. She described the American as loud mouthed and a bully, and 'like all bullies very cruel to the horses'. Rose added to Minnie's retort: 'You cruel brute! Good job if [the horse] kickem you!' by reporting that 'it was with great joy one day that we saw the biter bit ... Minnie was so overjoyed at the terrific bump the Yank had got that she was chuckling gleefully and saying over and over again: "Good job! Good job!"”. ${ }^{54}$

Rose accepted Minnie as an individual, describing her without recourse to either conventional racial stereotypes or patronisation. While Minnie was susceptible to drunkenness, she was 'very virtuous when the temptation was not at hand'. Rose represented her identity and authority as:

a very independent old soul who strongly resented the attempts by cooks or lady helps to shunt all the unpleasant or heavy jobs on to her and would come snorting to me to tell me, "My word, tha' one lazy

53 McGrath 1987: 53-55.

54 Cowen, Crossing Dry Creeks, 1961: 151-152. 
phella, wantem me do alla work; I gottem my own. I no askem t' do my work - you wantem tella the phella." And tellem I did for I hated such mean tricks. ${ }^{55}$

Two examples demonstrate a relationship of friendship and care between the two women. After the Aboriginal woman was struck by wind-borne galvanised iron, Rose took her into the homestead to 'bind her wounds and reduce the lumps and give her a good strong nip of whisky to steady her'. Similarly, when her husband became drunk and abusive, Rose took her to sleep on the veranda outside Rose's door. Rose affectionately referred to her as 'my beloved' Minnie or 'that silly old Minnie' and reiterated some of her outraged replies to perceived injustices against her. When a jackeroo laughed at her predicament when she was caught in a dust storm, Rose reported Minnie's retort: 'I no more washem your clothes, no more iron em shirts, no more takem ticks off your dog. You bad pfella, I no likem!', Rose adding that 'between each threat there was a terrific snort'. ${ }^{56}$

Separated from her family and female kin in an isolated location, Rose sympathised with Minnie's similar plight. After Pitta Pitta men killed the settler, Richard Welford, in 1872:

[Minnie] and her father and mother escaped into the country afterwards known as Connemara Station when the whites were exacting reprisals for the murders. They hid beside partly submerged logs in the waterholes in the daylight and fled by night ... and [Minnie] told me very graphically how terrified the blacks were and how they hid the fact that they were of the tribe who killed Welford. But every now and then they would meet ... and hold their corroboree of the flood and the snakes that drove them so far south. ${ }^{57}$

Away from her own country, Minnie had remained on Longford, unlike other Aborigines who had been moved onto missions or reserves in the early twentieth century. ${ }^{58}$

Rose grieved with her when Aborigines being transported from south-western Queensland to the Palm Island Aboriginal Settlement, north of Townsville, passed by Longford. Palm Island was gazetted as an Aboriginal reserve on 20 June 1914: ${ }^{59}$

\footnotetext{
Cowen, Crossing Dry Creeks, 1961: 117.

Cowen, Crossing Dry Creeks, 1961: 141.

Cowen, Crossing Dry Creeks, 1961: 184.

Copland, Richards and Walker 2006: 123.

Queensland Government Gazette, 1914, Vol. CII, No. 50: 1621.
} 
When the Government had the silly idea of gathering all the aborigines to the coast on an island (where in that damp climate they promptly died) we had several come along on the coach. They were very frightened as they knew that each one who had been taken away never came back and therefore they must be going to their death. They wailed and talked with my old Minnie who wailed and jabbered back and told me afterwards about "tha pore feller, he go longa island". ${ }^{60}$

Like Mary McConnel, Rose reported Indigenous autonomy and agency. Unlike Mary, Rose did not qualify her assessment with racial judgements. With an almost envious tone she reported that Minnie and Dick were,

very happy together and their laughter at night from their humpy was good to hear. I often wondered which of us whites they were taking off in that really brilliant mimicry of theirs which was not only of voice and inflection but also of gesture, walk and tilt of the head. ${ }^{61}$

In 1918, Cowen and his partner W J Langmore sold the property and the Cowens left in January 1919. ${ }^{62}$ Cowen purchased (again with Langmore) Mount Victoria, near Longreach, where the Cowens lived from 1919 to about 1924. In 1925, Rose Cowen was the registered owner of Kendal No. 2 in the Longreach district, a property that ran 90 cattle and 4,300 sheep. The Cowens had left Mount Victoria by 1925. They later either owned or had equity in Swan Vale (Jundah), Deuce Downs (Longreach) and Eden Downs (Dartmouth, east of Longreach). Bill Cowen died in 1935. ${ }^{63}$ Rose spent her later years with her younger, unmarried son, Clive, at Yeppoon near Rockhampton, where she died in July 1971, aged 92.

\section{Conclusion}

After Rose Scott's death in 1925 feminist activism continued. In the years between the World Wars 'the centre and outback [developed] as a new space for feminist attention', becoming significant places in which women could enact 'their own responsibilities as world women' and where 'white women activists promot[ed] Aboriginal women rights to selfhood and self-protection' ${ }^{64}$ Marilyn Lake has described this period as the 'golden age of the woman citizen' when women such as Constance Cooke, Mary Bennett and Bessie Rischbieth all

60 Cowen, Crossing Dry Creeks, 1961: 124.

61 Cowen, Crossing Dry Creeks, 1961: 125.

62 Cowen, Crossing Dry Creeks, 1961: 190; Rayment c. 1971: 156.

63 Australian Pastoral Directory1915: 181, 1919: 202, 1925: 225, 224; Cowen, Crossing Dry Creeks, 1961: 113-117; Lilley 1973: 52; 'Death at Longreach' (William Cowen's obituary), Morning Bulletin, Rockhampton, 31 August 1935: 6.

64 Holland 2001: 28, citing Paisley 1997: 122, 124-125. 
worked towards the equality of women - campaigns which included increased rights for Indigenous women. Anthropologist, Olive Pink, similarly brought to public attention the rights of Aboriginal women at this time. ${ }^{65}$ This was the period, too, when derogatory racial views about Aborigines were beginning to wane, with the lessening of the influencing force of social Darwinism. ${ }^{66}$ Rose Cowen's writing reflected these changes.

Rose understood the strength of women. During World War I, on holiday from Longford, she worked alongside other women in the Red Cross kitchen in the Kangaroo Point Military Hospital, Brisbane, serving meals to the wounded and ill soldiers. She herself was a Justice of the Peace and, in London, she had attended a British Women's Conference.

Rose's attitude against 'that despicable fetish of the English, respectability' ${ }^{67}$ enabled her to disregard the concepts of status and class. Straightforward, even blunt, in her appraisal of people (whether black or white), she embarrassed her family with her outspoken commentary. Circulation of Crossing Dry Creeks was suppressed until $1985 .{ }^{68}$ She represented Aboriginal people not as stereotyped racial constructs but as individuals depicted without sentimentality or censure. Rose portrayed Minnie as a strong and endearing personality, weighing 100 kilograms (compared with Rose's $38 \mathrm{~kg}$ ), sympathetic to Rose and hard working in helping her in the Herculean task of maintaining British standards of cleanliness in the dusty, arid outback.

Some of the ways that Indigenous women showed friendship to white women have become stereotypical. The examples of Aboriginal women taking lonely rural women on food foraging trips or swimming expeditions to the river or waterhole, or for walks in the bush showed the black women's generosity to the settlers. Aboriginal women succoured Katie Langloh Parker on Bangate station, near Angledool, close to the Queensland border in north-western New South Wales in the 1880s and 1890s; Ethel Hassell at Jarramungup, 170 kilometres north-east of Albany, south-western Western Australia, during the 1880s; and Jeannie Gunn of Elsey station near Katherine, Northern Territory, in the first years of the twentieth century. Some Aboriginal people allowed the settler women to write down their ancestral stories and customs. Katie Parker (later, Catherine Stow) wrote of the Noongahburrah women, members of the larger

\footnotetext{
65 Lake 1996: 166; Holland 2001: 30-33, 38; Marcus 1993: 111-135.

66 Reynolds 1996 [1987]: 118, 127.

67 Cowen, 'Recollections of a bush woman, 1879 to 1900 ', n.d., N9, Noel Butlin Archives Centre, ANU, p. 39.

68 Letter from Walter W Stone, editor of Biblionews, 3 July 1963, in NLA Ferguson copy of Crossing Dry Creeks.
} 
Euahlayi (Yuwaalaraay) group, and Hassell of the Wiilman. Alice Duncan-Kemp lived alongside the Karuwali, Marrula and Mitaka peoples and was able to record their stories in the twentieth century. ${ }^{69}$

This group of female settlers noted Indigenous women's independence, dignity and pride. Hassell referred to the Aborigines' 'keen sense of justice ... try to humbug a native your labour is in vain ... if they think they are not justly treated they quietly early one morning walk off'.$^{70}$ Emma Macpherson, on Keera station, near Bingara, New South Wales reported that when she asked Kamilaroi women to do some washing for her, they looked on it 'as so many favours conferred' and 'you can never be sure of the day or the hour that they may not take to the woods and disappear' ${ }^{71}$ Parker wrote of the 'born-lazy saunter' and sulky pout of one of the Noongahburrah 'black-but-comelys'. Negotiation and tact were the means by which a Wiilman woman convinced Hassell to allow a visiting friend to taste her toffee. ${ }^{72}$

These white women, however, upheld the class difference between themselves and the Indigenous women, allowing them into their homes - if at all-only to fulfil their roles as domestic servants. Hassell, for example, would meet the Aboriginal women 'at the wood-heap'. The pictures of Aboriginal people in these narratives are distilled through the white women's interpretation. Indigenous character sometimes emerges indirectly in anecdotes, aimed towards another outcome.

Rose and Minnie's working partnership, on the other hand, challenges Myrna Tonkinson's thesis that, on the frontier,

The Whites considered themselves to be superior and, even when they conceded humanity to the Blacks, did not consider them worthy of friendship or other relationships based on equality. ${ }^{73}$

69 Cf. Marcie Muir, My Bush Book: K. Langloh Parker's 1890s story of outback station life, Part Two: Based on the notebooks of an old-time squatter's wife 1879-1901, Rigby, Adelaide, 1982: 146-147; K Langloh Parker, The Euahlayi Tribe: A Study of Aboriginal Life in Australia, Archibald Constable and Company Ltd, London, 1905; and Marcie Muir, 'Stow, Catherine Eliza Somerville (Katie) (1856-1940)', ADB, NCB, ANU, http://adb. anu.edu.au/biography/stow-catherine-eliza-katie-8691/text15205, accessed 19 August 2013; Ethel Hassell, My Dusky Friends: Aboriginal life, customs, and legends and glimpses of station life at Jarramungup in the 1880s, C W Hassell, East Fremantle, 1975; Mrs Aeneas Gunn, The Little Black Princess: A True Tale of Life in the Never-Never Land, Alexander Moring Ltd, London; Melville and Mullen, Melbourne, 1906 [1905]; and Alice Duncan-Kemp (Mooraberrie, in Queensland's Channel Country) in the early twentieth century. DuncanKemp's books include Our Channel Country: Man and Nature in South-west Queensland, (1961) and Where Strange Gods Call (1968). For a discussion on interracial female friendship, cf. Dawson 2002: 79-84.

70 Hassell, My Dusky Friends, 1975: 84.

71 Foster 2010: 279-280; Macpherson, My Experiences in Australia, 1860: 231.

72 Muir, My Bush Book, 1982: 129-130; Hassell, My Dusky Friends, 1975: 36-37.

73 Tonkinson 1988: 28. 
Rose's story offers a twentieth-century perspective, depicting a relationship of shared endeavour. She reveals Indigenous authority with her comment that Minnie and Dick would laugh together at night, assuming that the target was one of 'us whites'. Minnie's physical and emotional help to the white woman at Longford gains from Rose a warm recognition of the Aborigine's strong and independent character. By writing honestly about Indigenous Australians, Rose revealed the moral integrity of other Aboriginal people in and around Longford and their hard-working efforts on behalf of the white newcomers. She has shown that, although a perception had grown from the mid-nineteenth century that the demise of Aborigines was inevitable, ${ }^{74}$ Indigenous people continued to be vital contributors to the development of Australia. Her acknowledgement of Indigenous identity and authority adds to the developing body of work emerging about nineteenth-century and early twentieth-century Indigenous Australians.

74 Markus 1994: 25. Markus suggests that contributing factors to the perception were the increased deaths of Aboriginal men and the increased number of Aboriginal babies fathered by white men. Russell McGregor's Imagined Destinies: Aboriginal Australians and the Doomed Race Theory, 1880-1939 (1997), explores the ways in which evolutionary ideas consolidated the expectation that the Aboriginal race would become extinct. This premise underlies Daisy Bates' The Passing of the Aborigines (1938). 



\section{Conclusion}

This book offers a fresh perspective in the debate on settler perceptions of Indigenous Australians. Specifically, it explores the influences of publishers' requirements and reader expectations on the way Aborigines were represented in published works. Because of the interdisciplinary nature of the study, its literary representations take the place of more 'straightforward' historical accounts. The writer's need to entertain her audience, as well as to 'educate' them, often led her to incorporate the traits and language of popular literary trends. Two of these were English Victorian romantic fiction, and the 'ripping yarn' adventure narrative, popular from the late nineteenth century. The incorporation of these literary genres often resulted in conflicting messages, and a confused and ambivalent rendition of Aborigines. These accounts are therefore rich sources for interpretation.

The study is situated within the dynamics of frontier life and their impact on the viewpoints and characters of those involved. The masks worn by some of the women hide their own opinions of Aboriginal people, including their empathy towards them. The extent to which the authors presented their writing to accommodate reader acceptance, taste and enjoyment, and their expectation to be 'informed' and entertained slanted their approach. By investigating the considerations of author and publisher, the study contributes to an understanding of the reason why perceptions of Aborigines persisted over time.

In the nineteenth century, racial attitudes and ignorance of native peoples fostered the distorted representations that Europeans made of Aborigines. Eliza Fraser was a forerunner in the accepted trend that was to follow. She became a puppet in the hands of those who wished to fabricate the image of Indigenous people for their own ends, not the least motivator being the need to proselytise in the name of evangelical Christianity.

A similar story surrounds the writing of Eliza Davies. Davies had seen and met members of the Ngarrindjeri and Meru people and her ambivalent views in The Story of an Earnest Life reveal the tension between her knowledge, born of experience, and her publisher's expectation of sales, generated by a perceived public demand for sensationalism. Nineteenth-century publishers may well have had a lot to answer for!

Emily Cowl joined the sensationalism bandwagon. She offered denigrating views of the Kurtjar people in some humorous or thrilling stories, aimed at enlivening a public talk and amusing her audience. These were presented as factual experiences in the guise of 'informing'. She was on steady ground because her 
interpretation conformed to nineteenth-century racial attitudes and confirmed the probable prejudice of her audience. Wherever her intentions were cast, her stories reveal Indigenous authority and sense of fun.

The narratives that tell us most about the fine qualities of Indigenous humanity belong to the three settler women, who closely knew individual Indigenous people. The writings of Katherine Kirkland, Mary McConnel and Rose Scott Cowen contradict the slanted views of the Eliza Fraser chroniclers, Eliza Davies and Emily Cowl. Katherine Kirkland, however, constrained by the novelty of recording close interracial connection, seemed unable to write openly about Moner balug women's help to her during her first months of settlement. Instead, she gave only hints of aspects of Wathaurong integrity in her record of settler life.

Mary McConnel was more forthcoming in her portrayal of the Dungibara people on Cressbrook. She individualised by name some of the women, men and children and offered specific details that built up a picture of the character and personality of each person. These portrayals emanated from direct Indigenoussettler transactions. Mary, however, remains the focal figure, who recorded the Aborigines' response to her motivations for change. She offers no information outside the reaction of the Aboriginal people to the settler group.

Rose Scott Cowen moved away from the idea of projecting a persona, the owner of which espoused a particular agendum. Her genuine personality emerges as she recalls her life 'as it was'. She similarly portrays candidly the personality and character of various Indigenous people whom she met in outback Queensland. Instead of stereotypical views associated with Aborigines, evident in the writing of the five previous women, Rose provides a frank representation of fully drawn, readily identifiable individuals.

Her vast experience of life in western Queensland enabled her to appreciate and applaud the character of the Indigenous people she knew in the Channel Country. The publication of her book in the mid-twentieth century facilitated the freedom to depict these people faithfully and honestly. She goes past portrayals purely of settler-Indigenous interactions to include aspects of Indigenous agency in their private lives, independent of settler cognisance, authority or control.

Historical discussion on interracial relationship or female friendship on the Australian frontier has focused on the white man or woman's interpretation. I have tried to look into and behind the 'eye of the beholder' to glean from white women's writing the lives, reactions and adaptations of Aboriginal people after white settlers infiltrated their lands. These women suggested other interpretations of Aboriginal people and their communities that contemporary representations might not have normally allowed. The crux of this work is the 
revelation of the Aborigines' help and concern for early settlers - their care and their courtesy, curiosity and comedy. The study provides evidence that, above all, the Aboriginal people held fast to their identity in the exercising of their cultural and territorial authority.

Having been replaced on their land, subjected to violence and categorised as 'inferior' by white observers, Indigenous Australians are only recently receiving recognition of their strength and heritage. Perhaps this book can contribute to the life stories from Aboriginal women, who are now working to transform public perceptions of the past.

Because of the confined scope of this project-limited as it is to five fresh case histories - further historical studies dealing with cross-cultural attitudes are needed in order to widen the perspective offered here. For example, what evidence can be found of people who formed close ties with the Aborigines in the early colonial period and who projected humanitarian views towards them? We know that Edward Curr and Robert Christison are two such people. ${ }^{1}$ But are there also instances of racist clichés persisting in writing from the twentieth century, even of women who have lived their entire lives in Australia? Did some rural women in the early twentieth century maintain dogmatic racism in their representation of Indigenous Australians? My work presents five case studies against which further investigations can be compared, contrasted and tested.

However, if this book has achieved its aim, even to a small degree, readers of the twenty-first century can, I hope, look beyond the racial stereotypes of our own time, and see every person, of whatever race or background, for the qualities that lie within, and not merely judge a person by the circumstances of his or her life. 



\section{Abbreviations}

$A D B$

AIATSIS

ANU

API

HSQJ

ML

NCB

NLA

NSW

RSSS

SLNSW

UK

UNSW

UWA
Australian Dictionary of Biography

Australian Institute of Aboriginal and Torres Strait Islander Studies

The Australian National University

Australian Public Intellectual

Historical Society of Queensland Journal

Mitchell Library

National Centre of Biography

National Library of Australia

New South Wales

Research School of Social Sciences

State Library of New South Wales

United Kingdom

University of New South Wales

University of Western Australia 



\section{Appendix A: The Works of the Women Writers}

\section{Eliza Frazer}

'Mrs Frazer's Narrative', Archives Office of New South Wales, Ref. SZ976, COD 183, and produced in Barry Dwyer and Neil Buchanan 1986, The Rescue of Eliza Fraser: 150th Anniversary Edition, Eliza Fraser Commemorative Committee, Noosa, Queensland.

Sydney Gazette, 18 October 1836.

\section{Eliza Davies}

Davies, Mrs Eliza 1881, The Story of an Earnest Life: A Woman's Adventures in Australia and in Two Voyages Around the World, Central Book Concern, Cincinnati.

\section{Emily Cowl}

Cowl, Mrs T Holder n.d, Some of My Experiences during a voyage to the Gulf of Carpentaria and three years' residence at Normanton in the early Seventies, Besley \& Pike Ltd, Brisbane.

\section{Katherine Kirkland}

Kirkland, Katharine [sic] c. 1995, Life in the Bush, published by Kenneth W Mackenzie, "Trawalla", Beaufort, Victoria; reprinted from Chambers's Miscellany of Useful and Entertaining Tracts, 1845, William and Robert Chambers, Edinburgh, Vol. 1, No. 8.

Kirkland, Katherine 186?, Vegetarian Cookery, By a Lady, With an Introduction Explanatory of the Principles of Vegetarianism By the Late Jas Simpson Esq., The Sixth Edition, Fred. Pitman, London. 
In the Eye of the Beholder

\section{Mary McConnel}

McConnel, Mary 1905, Memories of Days long gone by, By the Wife of an Australian Pioneer, M McConnel, Brisbane?. Alternative title: 'Queensland Reminiscences 1848-1870'.

Macleod, Mary, afterwards Mrs David C McConnel of Cressbrook, Queensland, 'Early Recollections', (MS precursor to Memories).

McConnel, Mrs David C 1897, Our Children's Hospital: A Story of Twenty-one Years 1876 to 1897, Thomson Brothers, Brisbane.

\section{Rose Cowen}

Cowen, Rose Scott 1961, Crossing Dry Creeks: 1879 to 1919, The Wentworth Press, Sydney.

\section{Manuscript collections}

'Across Dry Creek Beds' (catalogued as 'Memoir'), 1967, John Oxley Library, Brisbane, OM. 71-23.

'Details of my Family History', Newcastle and Region Public Library, Vertical files, 'S'.

'Recollections of a bush woman, 1879 to 1900', n.d., N9, Noel Butlin Archives Centre, The Australian National University, Canberra.

'Scott family-papers, mainly being biographical notes on Helenus Scott's family', 1833-1964, SLNSW, Sydney, MSS FM3/693. 


\section{Appendix B: The Works of Other Australian Women Writers Referred to in this Book}

Daly, Mrs Dominic 1887, Digging, Squatting and Pioneering Life in the Northern Territory of South Australia, Sampson Low, Marston, Searle \& Rivington, London.

Duncan-Kemp, A M 1933, Our Sandhill Country: Nature and Man in SouthWestern Queensland, Angus \& Robertson Ltd, Sydney.

Duncan-Kemp, Alice 1961, Our Channel Country: Man and Nature in South-west Queensland, Angus and Robertson, Sydney.

Duncan-Kemp, A M 1968, Where Strange Gods Call, W R Smith \& Paterson Pty Ltd, Brisbane.

Gunn, Mrs Aeneas 1906 [1905], The Little Black Princess: A True Tale of Life in the Never-Never Land, Alexander Moring Ltd, London; Melville and Mullen, Melbourne.

Hassell, Ethel 1975, My Dusky Friends: Aboriginal life, customs, and legends and glimpses of station life at Jarramungup in the 1880s, C W Hassell, East Fremantle.

King, Ann 1929 [1918], The Richmond River Experiences of Ann King: Later on Mrs T.N. Hollingworth, and now Mrs H. Dawe, believed to be the oldest resident of the Richmond River, D S Ford, Sydney, reprinted from lst edition, the Northern Star, Lismore, 1918.

McMaugh, Mary 192?, Pioneering on the Upper Macleay. Peeps into the Past: The Days of Yore, Chronicle Print, Wingham, NSW.

Macpherson, Mrs Allan 1860, My Experiences in Australia, Being Recollections of a Visit to the Australian Colonies in 1856-7. By a Lady, J F Hope, London.

Meredith, Louisa 1852, My Home in Tasmania, Sullivan's Cove, Adelaide, 1979. First published as My Home in Tasmania, during a residence of nine years, by Mrs Charles Meredith, John Murray, London.

Meredith, Mrs Charles (Louisa Ann) 1973, Notes and Sketches of New South Wales During a Residence in that Colony from 1839 to 1844, Ure Smith, Sydney, in association with National Trust of Australia (NSW). 
In the Eye of the Beholder

Moore-Bentley, Mary 1984, Journey to Durran Durra 1852-1885: A Story of the Bentley Family and the Gold Rush Era, Jeanne M Bow, Connells Point, NSW.

Mrs Fenton's Tasmanian Journal 1829-1830, 1986, Sullivan's Cove, Adelaide.

Muir, Marcie 1982, My Bush Book: K. Langloh Parker's 1890s story of outback station life, Part Two: Based on the notebooks of an old-time squatter's wife 1879-1901, Rigby, Adelaide.

Parker, K Langloh 1905, The Euahlayi Tribe: A Study of Aboriginal Life in Australia, Archibald Constable and Co. Ltd, London.

Smith, Mrs James 1880, The Booandik Tribe of South Australian Aborigines: A Sketch of their Habits, Customs, Legends, and Language: Also: An Account of the efforts made by Mr. and Mrs. James Smith to Christianise and Civilise them, Government Printer, Adelaide.

Wallace, Mrs Abraham, (Matilda Hill) n.d., Twelve Years' Life in Australia: From 1859 to 1871, South Australia. 


\section{Bibliography}

\section{Archival material}

\section{Australian Dictionary of Biography Files, Australian National University Archives, Canberra}

Correspondence to Professor Pike from John Kirkland Wilson Pike, 7 December 1965; Eaves Walton \& Stewart, Legal \& Historical Research papers, in 'Katherine Kirkland Biographical File'.

'David Cannon McConnel Biographical File'.

\section{National Library of Australia}

Index to Passengers to Sydney 1838-1842, Habart Samuel - Justus John, Archives Authority of New South Wales, AO Reel 4; Immigration Agents' Immigration Lists, April 1838-November 1841:Assisted Immigration, NLA mfm N229, Archives Authority of NSW, Reel No. 2134.

Flinders, M 1814, Chart of Terra Australis, Sheet III, East coast [cartographic material], G and W Nicol, London.

Nathan F. Spielvogel, 'When White Men First Looked on Ballarat', NLA MS 3776.

\section{State Records Authority of New South Wales}

Reports of John Baxter, Joseph Corralis, Lieutenant Otter, Captain Foster Fyans and John Graham, SZ976, COD 183.

\section{State Library of New South Wales}

Martens, Conrad, 'Bulimba on the Brisbane River, D. C. McConnel Esq., Nov. 21, 1851', Pencil 19 x 29.5 cm (ML PXC972, f.3).

'Scott family: mainly studio portraits of the Scott and Townsend families, ca. 1864-1886', SLNSW, Sydney, PXB 276. 
In the Eye of the Beholder

\section{State Library of Queensland, John Oxley Library, Brisbane}

McConnel, J C I 1963, 'The Lives of Frederic and John [sic] Anne McConnel', McConnel Family Papers, microform no. 755399.

\section{State Library of South Australia}

'Letter from George Gawler to Henry Cox, 1839', D 3063(L).

\section{Australian Institute of Aboriginal and Torres Strait Islander Studies}

Casey, Melba and Rolly Gilbert 1986, 'Kurtjar Stories', School of Australian Linguistics, Darwin Institute of Technology.

\section{Parliamentary papers and government gazettes}

The Public General Statutes of New South Wales (1852-1862), 1862, Government Printer, Sydney.

Queensland Government Gazette, 16 December 1897.

Queensland Government Gazette, 1914, Vol. CII, No. 50.

Registrars, New South Wales, Queensland and South Australia Births, Deaths and Marriages

Votes and Proceedings of the Victorian Legislative Assembly, 1877-78.

\section{Directories}

Australian Pastoral Directory, 1907, 1915, 1917, 1919, 1921, 1923, 1925, 1927.

Bailliere's Victorian Gazetteer and Road Guide Containing the Most Recent and Accurate Information as to Every Place in the Colony, 1865, Compiled by Robt. P Whitworth, F F Bailliere, Melbourne.

The Official Post Office Directory of Queensland, 1871.

Whitworth, R R, Compiled Under the Authority of the Postmaster-General 1874, The Official Post Office Directory (Professional, Squatting, and Trade) of Queensland, F F Bailliere, Brisbane, Sydney. 
Wise's Queensland Post Office Directory, 1895-1899.

Wise's Queensland Post Office and Official Directory, 1900-1911.

\section{Primary source books, pamphlets, articles}

A Mother's Offering to Her Children by A Lady Long Resident in New South Wales, 1979 [1841], Facsimile edition, The Jacaranda Press, Milton, Queensland; first printed by the Gazette, Sydney.

A Statement of the Objects of the Committee of the Societies for the Propagation of the Gospel in Foreign Parts and for Promoting Christian Knowledge (Australia), 1836, Stephen and Stokes, Sydney.

Arthur, Timothy Shay 1874, Woman to the Rescue. A Story of the New Crusade, J M Stoddart \& Co., Queen City Publishing Co., Cincinnati (NLA microfilm mc 109).

Balfour, J O 1845, A Sketch of New South Wales, Smith, Elder and Co., London.

Banks, Mary Macleod 1931, Memories of Pioneer Days in Queensland, Heath Cranton Limited, London.

Bates, Daisy 1938, The Passing of the Aborigines: a Lifetime spent among the Natives of Australia, John Murray, London.

Beaglehole, J C (ed.) 1962, The Endeavour Journal of Joseph Banks 1768-1771, Volume II, The Trustees of the Public Library of New South Wales in association with Angus and Robertson, Sydney.

Bentham, Jeremy 1970 [1789], AnIntroduction to the Principles of Morals and Legislation, edited by J H Burns and H L A Hart, Athlone Press, London.

Bladen, F H (ed.) 1895, Historical Records Of New South Wales, Vol. III-Hunter 1796-1799, Charles Potter, Sydney.

Boldrewood, Rolf (Thomas Alexander Browne) 1888, Robbery Under Arms, first published in serial form by the Sydney Mail in 1882; and in book form by Remington, London.

— 1969 [1884], Old Melbourne Memories, William Heinemann Ltd, Melbourne.

Bride, Thomas Francis (ed.) 1983 [1898], Letters from Victorian Pioneers: A Series of Papers on the Early Occupation of the Colony, the Aborigines, Etc, Lloyd O'Neil Pty Ltd, South Yarra, Victoria. 
In the Eye of the Beholder

Brown, P L (ed.) 1935, The Narrative of George Russell of Golf Hill will Russellania and Selected Papers, OUP, London.

- 1958, Clyde Company Papers, Vol. III, 1841-45, OUP, London.

Bynoe, Charles 1992, Memories of Normanton: An Aboriginal Perspective, Normanton State School.

Chambers's Miscellany of Useful and Entertaining Tracts 1845, William and Robert Chambers, Edinburgh, Vol. 1, No. 8.

Chambers, W 1882, Story of A Long and Busy Life, W \& R Chambers, Edinburgh and London.

Clark, Ian D (ed.) 2000, The Journals of George Augustus Robinson, Chief Protector, Port Phillip Aboriginal Protectorate, Volume One: 1 January 1839 - 30 September 1840, Second Edition, Heritage Matters, Ballarat, Victoria.

Cunningham, P 1827, Two Years in New South Wales; A Series of Letters, Comprising Sketches of the Actual State of Society in that Colony; Of Its Peculiar Advantages to Emigrants; Of Its Topography, Natural History, \&c. \&c., In Two Volumes, Vol. II, Henry Colburn, London.

Curr, Edward M 2001 [1883], Recollections of Squatting in Victoria, Then Called the Port Phillip District (From 1841 to 1851), Rich Rivers Printers, Echuca, Victoria.

Curtis, John 1838, Shipwreck of the Stirling Castle containing A Faithful Narrative of the Dreadful Sufferings of the Crew, and the Cruel Murder of Captain Fraser by the Savages. Also, The Horrible Barbarity of the Cannibals Inflicted upon The Captain's Widow, Whose Unparalleled Sufferings are Stated by Herself, and Corroborated by the Other Survivors. To Which is Added, The Narrative of the Wreck of the Charles Eaton, in the Same Latitude, George Virtue, London.

Dampier, William 1937 [1697], A New Voyage Round the World, With an Introduction by Sir Albert Gray, Adam and Charles Black, London.

Darwin, Charles 1889, Journal of Researches into the Natural History and Geology of the Countries Visited During the Voyage of H.M.S. "Beagle" Round the World, Sixth Edition, Ward, Lock and Co., London, New York, and Melbourne.

- 1999 [1859], The Origin of Species By Means of Natural Selection or The Preservation of Favoured Races in the Struggle for Life, Claremont Classics, Australia. 
Darwin, Charles and Alfred Russel Wallace 1958, Evolution by Natural Selection, Published for the XV International Congress of Zoology and The Linnean Society of London, Cambridge University Press, Cambridge.

Defoe, Daniel 1719, The Life and Strange and Surprizing Adventures on Robinson Crusoe of York, Mariner: who lived eight and twenty years, all alone in an uninhabited island on the coast of America, near the mouth of the great river of Oroonoque; having been cast on shore by shipwreck, whereon all the men perished but himself. With an account of how he was at last as strangely deliver'd by pyrates. Written by himself, W Taylor, London.

Flanagan, Roderick 1888, The Aborigines of Australia, first published as a series of articles in 1853-54 in the Sydney Empire, Edward F Flanagan and George Robertson and Company.

Ford, Henry A and Mrs Kate B Ford 1881, History of Cincinnati, Ohio, With Illustrations and Biographical Sketches, L A Williams \& Co., Cleveland, Ohio.

Haggard, H Rider 1969 [1886], She: A History of Adventure, Macdonald \& Co., London.

Hamilton, J C n.d., Pioneering Days in Western Victoria, n.p.

Hill, W R O 1907, Forty-Five Years' Experience in North Queensland, H Pole \& Co., Brisbane.

Hume, David 1964, 'Of National Characters', in Essays: Moral, Political, and Literary, Edited, With Preliminary Dissertations and Notes, by T H Green and T H Grose, in Two Volumes, Vol 1, Reprint of the new edition, London, 1882, Scientia Verlag Aalen, Germany.

Jersey, Margaret Elizabeth Leigh Child-Villiers (The Dowager Countess of Jersey) 1922, Fifty-one Years of Victorian Life, John Murray, London.

Johnston, William 1918, 'Old Bulimba', The Historical Society of Queensland Journal, Vol. 1, No. 5.

Keynes, Richard Darwin (ed.) 1988, Charles Darwin's Beagle Diary, Cambridge University Press, Cambridge.

Lang, John Dunmore 1861, Queensland, Australia; A Highly Eligible Field For Emigration, and the Future Cotton-Field of Great Britain: with a Disquisition on The Origin, Manners, and Customs of the Aborigines, Edward Stanford, London. 
In the Eye of the Beholder

Long, Edward 1774, The History of Jamaica, Or, General Survey of the Antient [sic] and Modern State of that Island: with Reflections on its Situation, Settlements, Inhabitants, Climate, Products, Laws, and Government, T Lowndes, London.

Martin, Joseph Lemuel 1870, The Voice of the Seven Thunders: Or Lectures on the Apocalypse, Central Book Concern, Chicago and Cincinnati.

Mathew, John 1910, Two Representative Tribes of Queensland: With an Inquiry concerning the Origin of the Australian Race, T Fisher Unwin, London and Leipsic.

Memorandum of Association of the Australasian Pioneers' Club, 1915, H J Gurd \& Co., Sydney.

Millett, Mrs Edward 1980 [1872], An Australian Parsonage or, The Settler and the Savage in Western Australia, Facsimile Edition, Univerity of Western Australia Press, Nedlands, Western Australia (originally published by Edward Stanford, London).

Mitchell, Thomas Livingston 1839, Three Expeditions into the Interior of Eastern Australia: with Descriptions of the Recently Explored Region of Australia Felix and of the Present Colony of New South Wales, Volume 1, Second edition, T \& $\mathrm{W}$ Boone, London.

Mundy, Lt Colonel Godfrey Charles 1852, Our Antipodes: Or, Residence and Rambles in The Australian Colonies. With A Glimpse of The Gold Fields, In Three Volumes, Second Edition, Revised, Richard Bentley, London, Vol. I.

Narrative of the Capture, Sufferings, and Miraculous Escape of Mrs Eliza Fraser, 1837, Charles S Webb, New York.

Nevins, Allan (ed.) 1954, James Fenimore Cooper's The Leatherstocking Saga: being those parts of The Deerslayer, The Last of the Mohicans, The Pathfinder, The Pioneers, and The Prairie which specially pertain to Natty Bumppo otherwise known as Pathfinder, Deerslayer, or Hawkeye; the whole arranged in chronological order from Hawkeye's youth on the New York frontier in King George's War until his death on the Western prairies in Jefferson's Administration, Pantheon Books, New York.

Nott, Josiah and George Gliddon 1857, Types of Mankind: or, Ethnological Researches, Based Upon the Ancient Monuments, Paintings, Sculptures, and Crania of Races, 8th edition, J B Lippincott, Philadelphia.

Palmer, Edward 1983 [1903], Early Days in North Queensland, Angus \& Robertson, London, Sydney. 
Richardson, Samuel 1740, Pamela; or Virtue Rewarded, Messrs Rivington and Osborn, London.

Romanov-Hughes, Alexander (compiler) 1995, Coastal Passengers to Port Phillip, 1839, Romanov-Hughes, Taradale, Victoria.

Russell, Henry Stuart 1989 [1888], The Genesis of Queensland, Vintage Books, Toowoomba, Queensland.

Russell, William 1991 [1914], My Recollections, The Oaks Historical Society, Camden, NSW.

Scott, Sir Walter, Marmion, Canto VI, 17.

Smiles, Samuel 1874 [1859], Self-Help: With Illustrations of Conduct and Perseverance, John Murray, London.

- 1879 [1871], Character, New edition, John Murray, London.

— 1880 [1875], Thrift, John Murray, London.

- 1880, Duty: With Illustrations of Courage, Patience and Endurance, John Murray, London.

Smyth, R Brough 1878, The Aborigines of Victoria: with Notes Relating to the Habits of the Natives of other Parts of Australia and Tasmania, Volume II, George Robertson, Melbourne.

Sturt, Charles 1982, Mount Bryan Expedition 1839, Sullivan's Cove, Adelaide.

Sturt, Mrs Napier George 1899, Life of Charles Sturt, Sometime Capt, 39th Regt and Australian Explorer, Smith, Elder, \& Co., London.

Swift, Jonathan 1940 [1726], Gulliver's Travels, J M Dent \& Sons Ltd, London.

Tench, Captain Watkin 1979, Sydney's First Four Years: A Narrative of the Expedition to Botany Bay and A Complete Account of the Settlement at Port Jackson 1788-1791, introduced and annotated by L F Fitzhardinge, Library of Australian History in association with the Royal Australian Historical Society, Sydney.

The Cressbrook Estate: The Property of Messrs J H McConnel \& Son, ?1910, n.p., Sydney.

The Queen of the Colonies; or, Queensland As I Know It. By An Eight Years' Resident, 1876, Sampson Low, Marston, Searle, \& Rivington, London. 
In the Eye of the Beholder

The Way We Civilise; Black and White; The Native Police; A Series of Articles and Letters Reprinted from the Queenslander, 1880, G and J Black, Brisbane.

White, Patrick 1976, A Fringe of Leaves, Jonathan Cape, London.

Young, John Atherton (ed.) 1987, Jane Bardsley's Outback Letterbook Across The Years, 1896-1936, Angus \& Robertson Publishers, North Ryde, NSW.

\title{
Newspapers and periodicals
}

\author{
Australasian \\ Bell's Weekly Messenger \\ Brisbane Courier \\ The Edinburgh Evening Courant \\ Geelong Advertiser \\ Illawarra Mercury \\ Kiama Examiner \\ Moreton Bay Courier \\ Morning Bulletin, Rockhampton \\ Newcastle Mining Herald and Miners' Advocate \\ Newcastle Morning Herald \\ Port Phillip Gazette \\ Port Phillip Herald
}

Queensland Naturalist: Journal of the Queensland Naturalists' Club, Vol. 19, Nos 1-3, November 1968, 'Fraser Island Number'.

South Australian Advertiser

Sydney Gazette

Sydney Herald

Sydney Mail

The Free Church of Scotland Monthly Record 
The Historical Society of Queensland Journal

The Pastoralists' Review

The Sun (Sydney)

\section{Australian Dictionary of Biography entries}

'Angas, George Fife (1789-1879)'

'Angas, John Howard (1823-1904)', Sally O’Neill

'Barton, Charlotte (1796-1867)', Patricia Clarke

'Browne, Thomas Alexander [Rolf Boldrewood] (1826-1915)', T Inglis Moore

'Fraser, Eliza Anne (c. 1798-1858?)', Elaine Brown

'Gawler, George (1795-1869)', R Hetherington

'Gould, John (1804-1881)', A H Chisholm

'Groom, William Henry (1833-1901)', D B Waterson

'Hamilton, Edward William Terrick (1809-1898)', J R Robertson

'Howe, Ann (c. 1802-1842)', Sandy Blair

'Kirkland, Katherine (1808-1892)', Jean Hagger

'McConnel, David Cannon (1818-1885)', H J Gibbney

'Mitchell, David Scott (1836-1907)', G D Richardson

'Morehead, Boyd Dunlop (1843-1905)'

'Murphy, Sir Francis (1809-1891)', Margot Beever

'Scott, Helenus (1802-1879)', Nancy Gray

'Scott, Robert (1799-1844)', Nancy Gray

'Scott, Rose (1847-1925)', Judith Allen

'Smith, Christina (1809?-1893)', Leith G MacGillivray

'Spielvogel, Nathan Frederick (1874-1956)', Weston Bate 
In the Eye of the Beholder

'Stow, Catherine Eliza Somerville (Katie) (1856-1940)', Marcie Muir

'Thomson, Sir Edward Deas (1800-1879)', M E Osborne

\section{Secondary source books, pamphlets, journal articles (and chapters in edited collections)}

Aboriginals in Victoria, 1976, Commonwealth Government Printing Unit, Melbourne.

Adams, David (ed.) 1988, The Letters of Rachel Henning, first published in the Bulletin in 1951-52 and in book form by Angus \& Robertson Ltd, Sydney, in 1963, Penguin Books, Ringwood, Victoria.

Adelaide, Debra 1988, Australian Women Writers: A Bibliographic Guide, Pandora Press, London.

Adelaide, Debra (ed.) 1988, A Bright and Fiery Troop: Australian Women Writers of the Nineteenth Century, Penguin Books, Ringwood, Victoria.

Adelaide, Debra 1991, Bibliography of Australian Women's Literature 1795-1990: A Listing of Fiction, Poetry, Drama and Non-fiction Published in Monograph Form Arranged Alphabetically by Author, D W Thorpe in association with National Centre for Australian Studies, Port Melbourne.

Allen, Maureen 1996, Cressbrook, published by author, Caldbeck, Cumbria, United Kingdom.

Alexander, Michael, (adapted by Ida Veitch) 1981, Mrs Fraser On The Fatal Shore, Thomas Nelson Australia Pty Ltd, Melbourne.

Allingham, Anne 1977, Taming the Wilderness: The First Decade of Pastoral Settlement in the Kennedy District, History Department, James Cook University of North Queensland, Townsville.

Altick, Richard D 1957, The English Common Reader: A Social History of the Mass Reading Public 1800-1900, University of Chicago Press, Chicago.

- 1973, Victorian People and Ideas: A Companion for the Modern Reader of Victorian Literature, W W Norton and Co. Inc., New York.

Anderson, Hugh 1969, The Flowers of the Field: A History of Ripon Shire, Together with Mrs Kirkland's Life in the Bush from Chambers's Miscellany, 1845, Hill of Content Publishing Co. Pty Ltd, Melbourne. 
Anderson, Kay and Colin Perrin 2007, “The miserablest people in the world": race, humanism and the Australian Aborigine', The Australian Journal of Anthropology, Vol. 18, No. 1.

Aplin, Graeme, S G Foster and Michael McKernan (eds) 1987, Australians: A Historical Dictionary, Fairfax, Syme \& Weldon Associates, Sydney.

Arthur, J M 2003, The Default Country: A Lexical Cartography of TwentiethCentury Australia, UNSW Press, Sydney.

Atkinson, Alan 2004, The Europeans in Australia: A History, Volume Two: Democracy, Oxford University Press, Melbourne.

Attenbrow, Valerie 2002, Sydney's Aboriginal Past: Investigating the Archaeological and Historical Records, UNSW Press, Sydney.

Attwood, Bain 1999, 'My Country':A History of the Djadja Warrung 18371864, Monash Publications in History: 25, Department of History, Monash University and Dja Dja Wrung Aboriginal Association Inc., Melbourne.

Attwood, Bain and S G Foster (eds) 2003, Frontier Conflict: The Australian Experience, National Museum of Australia, Canberra.

Attwood, Bain and Fiona Magowan (eds) 2001, Telling Stories: Indigenous History and Memory in Australia and New Zealand, Allen \& Unwin, Crows Nest, NSW.

Baker, D W A 1985, Days of Wrath: A Life of John Dunmore Lang, Melbourne University Press, Carlton, Victoria.

Banfield, Lorna L 1955, Like The Ark: The Story of Ararat, F W Cheshire, Melbourne.

Barwick, Diane E, 'And the lubras are ladies now', in Fay Gale (ed.) 1974, Women's Role in Aboriginal Society, Australian Institute of Aboriginal Studies, Canberra.

Bauer, F H 1964, Historical Geography of White Settlement in Part of Northern Australia. Part 2: The Katherine - Darwin Region, Commonwealth Scientific and Industrial Research Organisation, Division of Land Research and Regional Survey, Divisional Report No. 64/1, Canberra.

Bennett, M M 1927, Christison of Lammermoor, Alston Rivers Ltd, London.

Berndt, Catherine H 1980,'Aboriginal women and the notion of "the marginal man"', in R Berndt and C Berndt (eds), Aborigines of the West: Their Past and Their Present, Revised Edition, UWA Press, Perth. 
In the Eye of the Beholder

Berndt, Catherine H and Ronald M Berndt 1983, The Aboriginal Australians: The First Pioneers, Pitman, Melbourne.

Billis, R V and A S Kenyon 1974 [1930], Pastures New: An Account of the Pastoral Occupation of Port Phillip, Stockland Press Pty Ltd, Melbourne.

- 1974 [1932], Pastoral Pioneers of Port Phillip, Second Edition, Stockland Press Pty Ltd, Melbourne.

Bolt, Christine 1971, Victorian Attitudes to Race, Routledge \& Kegan Paul, London, University of Toronto Press, Toronto.

Boys, Robert Douglass 1959 [1935], First Years at Port Phillip 1834-1842: Preceded by a Summary of Historical Events from 1768, Robertson \& Mullens Ltd, Melbourne.

Brewer, John 1997, The Pleasures of the Imagination: English Culture in the Eighteenth Century, Farrar Straus Giroux, New York.

Brewster, Anne 1996, Reading Aboriginal Women's Autobiography, Sydney University Press in association with Oxford University Press, Melbourne.

Broome, Richard 2002 [1982], Aboriginal Australians: Black Responses to White Domination 1788-2001, Allen \& Unwin, Crows Nest, NSW.

- 2005, Aboriginal Victorians: A History Since 1800, Allen \& Unwin, Crows Nest, NSW, Supported by La Trobe University, Melbourne.

— 2010, Aboriginal Australians: A History Since 1788, Allen \& Unwin, Crows Nest, NSW.

Brown, Elaine 1994, 'The legend of Eliza Fraser - a survey of the sources', Journal of the Royal Historical Society of Queensland, Vol. XV, No. 7.

- 2000, Cooloola Coast: Noosa to Fraser Island: The Aboriginal and Settler Histories of a Unique Environment, University of Queensland Press, St Lucia, Queensland.

Brownhill, Walter Randolph 1955, The History of Geelong and Corio Bay, Wilks \& Co. Ltd, Melbourne.

Bulbeck, Chilla 1991, 'Aborigines, memorials and the history of the frontier', in John Rickard and Peter Spearritt (eds), Packaging the Past? Public Histories, Australian Historical Studies, Department of History, University of Melbourne.

Bull, Jean n.d., Historic Brisbane Stations, A Queensland Country Life Publication, Brisbane. 
Butcher, Barry W 1988, 'Gorilla warfare in Melbourne: Halford, Huxley and "Man's place in nature", in R W Home (ed.), Australian Science in the Making, Cambridge University Press in association with Australian Academy of Science, Cambridge and Melbourne.

- 1994, 'Darwinism, Social Darwinism, and the Australian Aborigines: a reevaluation', in Roy MacLeod and Philip F Rehbock (eds), Evolutionary Theory and Natural History in the Pacific: Darwin's Laboratory, University of Hawai'i Press, Honolulu.

— 1999, 'Darwin down under: science, religion, and evolution in Australia', in Ronald L Numbers and John Stenhouse (eds), Disseminating Darwinism: The Role of Place, Race, Religion, and Gender, Cambridge University Press, Cambridge and New York.

Buxton, G L 1977, '1870-90', in F K Crowley (ed.), A New History of Australia, William Heinemann, Melbourne.

Cannon, Michael 1990, Who Killed the Koories? The True, Terrible Story of Australia's Founding Years, William Heinemann Australia, Melbourne.

Christie, M F 1979, Aborigines in Colonial Victoria, 1835-86, Sydney University Press, Sydney.

Clark, Ian D 1995, Scars in the Landscape: A Register of Massacre Sites in Western Victoria, 1803-1859, Australian Institute of Aboriginal and Torres Strait Islander Studies, Report Series, Canberra.

- 2003, 'That's My Country Belonging to Me': Aboriginal Land Tenure and Dispossession in Nineteenth Century Western Victoria, Ballarat Heritage Services, Ballarat.

Clarke, Patricia 1985, The Governesses: Letters From The Colonies 1862-1882, Hutchison of Australia, Hawthorn, Victoria.

- 1986, A Colonial Woman: The Life and Times of Mary Braidwood Mowle 1827-1857, Allen \& Unwin, North Sydney.

- 1988, Pen Portraits: Women Writers and Journalists in Nineteenth Century Australia, Allen \& Unwin, North Sydney.

- 1990, Pioneer Writer: The Life of Louisa Atkinson: Novelist, Journalist, Naturalist, Allen \& Unwin, North Sydney.

— 1999, Rosa! Rosa! A Life of Rosa Praed, Novelist and Spiritualist, Melbourne University Press, Carlton, Victoria. 
In the Eye of the Beholder

Clarke, Patricia and Dale Spender 1992, Life Lines: Australian Women's Letters and Diaries, 1788-1840, Allen \& Unwin, St Leonards, NSW.

Clendinnen, Inga 2003, Dancing with Strangers, The Text Publishing Company, Melbourne.

— 2006, 'The history question: Who owns the past?', Quarterly Essay, Issue 23.

Cole, Anna, Victoria Haskins and Fiona Paisley (eds) 2005, Uncommon Ground: White Women in Aboriginal History, Aboriginal Studies Press, Canberra.

Copland, Mark, Jonathan Richards and Andrew Walker 2006, One Hour More Daylight: A Historical Overview of Aboriginal Dispossession in Southern and Southwest Queensland, The Social Justice Commission, Catholic Diocese of Toowoomba, Queensland.

Croll, Robert Henderson, in collaboration with Roland R Wettenhall 1937, Dr. Alexander Thomson: A Pioneer of Melbourne and Founder of Geelong, Robertson \& Mullens, Melbourne.

Cunnington, Phillis and Anne Buck 1965, Children's Costume in England: From the Fourteenth to the end of the Nineteenth Century, Adam \& Charles Black, London.

Curthoys, Ann 1993, 'Identity crisis: colonialism, nation, and gender in Australian history', in Gender \& History: Special Issue on Gender, Nationalisms and National Identities, Vol. 5, No. 2.

— 1997, 'Thinking about history', in Patricia Grimshaw and Diane Kirkby (eds), Dealing With Difference: Essays in Gender, Culture and History, Department of History, The University of Melbourne.

Curthoys, Ann and Ann McGrath (eds) 2000, Writing Histories: Imagination and Narration, School of Historical Studies, Monash University, Clayton, Victoria.

Dalziell, Tanya 2002, “'We should try, while there is yet time, to gather all the information possible of a race dying out": unsettling sympathetic women', Australian Feminist Studies, Vol. 17, No. 39.

Darian-Smith, Kate 1996, “"Rescuing" Barbara Thompson and other white women: captivity narratives on Australian frontiers', in Kate Darian-Smith, Liz Gunner and Sarah Nuttall (eds), Text, Theory, Space: Land, Literature and History in South Africa and Australia, Routledge, London.

Dawes, Sean 1991, 'John Gould: travels and faunal collections in South Australia', Journal of the Historical Society of South Australia, No. 19. 
Dawson, Barbara 1996, 'Holding Selectors at Bay: An Analysis of the Robertson Land Acts on the Property of Bibbenluke in the Southern Monaro 18611884', MA Thesis, ANU.

— 1999, 'The end of pastoral paternalism: William Bradley of Bibbenluke and Robert Campbell of Duntroon', Canberra Historical Journal, New Series No. 43.

Dawson, Barbara (Chambers) 2000, 'Striking out for independence: moves towards self-determination and self-sufficiency on the southern Monaro property of Bibbenluke, 1861-1884', Labour History, No. 79.

- 2002, 'Sisters under the skin? Friendship: crossing the racial gulf', Crossings: Bulletin of the International Australian Studies Association, Australian Studies Centre, University of Queensland, Vol. 7.3: E-journal.

Dawson, Barbara Chambers 2007, 'In the Eye of the Beholder: Representations of Australian Aborigines in the Published Works of Colonial Women Writers', PhD Thesis, ANU.

Dawson, Barbara 2009, 'Four intrepid Scotswomen: travellers to the Australian colonies and their representations of Aborigines', History Scotland Journal, Vol. 9, No. 4.

De Courtais, Georgine 1988, Women's Headdress and Hairstyles in England from $A D 600$ to the present day, B T Batsford Ltd, London.

Desmond, Adrian and James Moore 1991, Darwin, Michael Joseph Ltd, London.

De Vries, Susanna 1995, Strength of Spirit: Pioneering Women of Achievement from First Fleet to Federation, Millennium Books, Alexandria, NSW.

Dixon, Robert 1995, Writing the Colonial Adventure: Race, Gender and Nation in Anglo-Australian Popular Fiction, 1875-1914, Cambridge University Press, Cambridge, New York.

Donegan, Jacqui and Raymond Evans 2001, 'Running amok: the Normanton race riots of 1888 and the genesis of white Australia', in Ffion Murphy (ed.), The Show Girl and the Straw Man, an issue of the Journal of Australian Studies, No. 71, University of Queensland Press, St Lucia, Queensland.

Douglas, Mary 1975, Implicit Meanings: Essays in Anthropology, Routledge \& Kegan Paul, London and Boston.

Drummond, Yolanda 1993, 'Progress of Eliza Fraser', Journal of the Royal Historical Society of Queensland, Vol. XV, No. 1. 
In the Eye of the Beholder

Enders, Mike and Benoit Dupont 2001, Policing the Lucky Country, Hawkins Press, Annandale, NSW.

Evans, Julie, Patricia Grimshaw and Ann Standish 2003, 'Caring for Country: Yuwalaraay women and attachments to land on an Australian colonial frontier', Journal of Women's History, Vol. 14, No. 4.

Evans, Raymond 2003, 'Across the Queensland frontier', in Bain Attwood and S G Foster (eds), Frontier Conflict: The Australian Experience, National Museum of Australia, Canberra.

- 2004, "Plenty shoot 'em": the destruction of Aboriginal societies along the Queensland frontier', in A Dirk Moses (ed.), Genocide and Settler Society: Frontier Violence and Stolen Indigenous Children in Australian History, Berghahn Books, New York and Oxford.

Evans, Raymond, Kay Saunders and Kathryn Cronin 1993, Race Relations in Colonial Queensland: Exclusion, Exploitation and Extermination, University of Queensland Press, St Lucia, Queensland.

Ferres, Kay (ed.) 1993, The Time to Write: Australian Women Writers 1890 1930, Penguin Books, Ringwood, Victoria.

Fisher, Rod 1987, 'David Cannon McConnel's second "bump of hope": Bulimba House and farm 1849-1853', Brisbane: People, Places and Pageantry, Papers No. 6, Brisbane History Group, Brisbane.

Flannery, Tim (ed.) 1998, The Explorers: Stories of Discovery and Adventure from the Australian Frontier, The Text Publishing Company, Melbourne.

Fletcher, J and J Burnswoods 1988, Government Schools of New South Wales Since 1848, NSW Department of Education, Sydney.

Foster, Robert 2000, 'Rations, coexistence, and the colonisation of Aboriginal labour in the South Australian pastoral industry, 1860-1911', Aboriginal History, Vol. 24.

Foster, Robert, Rick Hosking and Amanda Nettelbeck 2001, Fatal Collisions: The South Australian Frontier and the Violence of Memory, Wakefield Press, Kent Town, South Australia.

Foster, Stephen 2010, A Private Empire, Pier 9, Millers Point, NSW.

Francis, Mark 1996, 'Social Darwinism and the construction of institutionalised racism in Australia', Journal of Australian Studies, No. 50/51. 
Frost, Lucy (ed.) 1984, No Place for a Nervous Lady: Voices from the Australian Bush, McPhee Gribble/Penguin Books with the assistance of the Literature Board of the Australia Council, Melbourne.

Frost, Lucy 1992, A Face in the Glass: The Journal and Life of Annie Baxter Dawbin, William Heinemann Australia, Port Melbourne, Victoria.

Frost, Lucy (ed.) 1998, The Journal of Annie Baxter Dawbin July 1858 - May 1868, University of Queensland Press, in association with The State Library of New South Wales.

Gascoigne, John 1994, Joseph Banks and the English Enlightenment: Useful Knowledge and Polite Culture, Cambridge University Press, Cambridge, New York.

Gibson, Ross 1984, Diminishing Paradise: Changing Literary Perceptions of Australia, Sirius Books, Angus \& Robertson, Australia.

Giles, Fiona (ed.) 1987, From The Verandah: Stories of Love and Landscape by Nineteenth Century Australian Women, McPhee Gribble/Penguin Books, Melbourne.

Goodall, Jane R 2002, Performance and Evolution in the Age of Darwin: Out of the Natural Order, Routledge, London and New York.

Goodman, Jordan 2005, The Rattlesnake: A Voyage of Discovery to the Coral Sea, Faber and Faber, London.

Gott, B 1983, 'Murnong-Microseris scapigera: A study of a staple food of Victorian Aboriginals', Australian Aboriginal Studies, 2.

Green, Neville 1984, Broken Spears: Aborigines and Europeans in the Southwest of Australia, Focus Education Services, Perth.

- 1989, Aborigines of the Albany Region, 1821-1898, University of Western Australia Press, Nedlands, WA.

- 1995, The Forrest River Massacres, Fremantle Arts Centre Press, Fremantle, WA.

Greenwood, Gordon (ed.) and Laverty, John 1959, Brisbane 1859, 1959: A History of Local Government, The Council of the City of Brisbane, Queensland.

Griffin, Graeme M 1993, They Came to Care: Pastoral Ministry in Colonial Australia, Joint Board of Christian Education, Melbourne.

Griffiths, Tom 1996, Hunters and Collectors: The Antiquarian Imagination in Australia, Cambridge University Press, Cambridge and Melbourne. 
In the Eye of the Beholder

Griffiths, Tom and Libby Robin (eds) 1997, Ecology and Empire: Environmental History of Settler Societies, Melbourne University Press, Carlton South, Victoria.

Grimshaw, Patricia 1981, 'Aboriginal women: a study of cultural contact', in Norma Grieve and Patricia Grimshaw (eds), Australian Women: Feminist Perspectives, Oxford University Press, Melbourne.

Grimshaw, Patricia and Julie Evans 1996, 'Colonial women on intercultural frontiers: Rosa Campbell Praed, Mary Bundock and Katie Langloh Parker', Australian Historical Studies, Vol. 27, 106.

Grimshaw, Patricia, Marilyn Lake, Ann McGrath, and Marian Quartly 1994, Creating A Nation, McPhee Gribble Publishers, Penguin Books Australia Ltd, Ringwood, Victoria.

Gunn, Simon 2000, The Public Culture of the Victorian Middle Class: Ritual and authority and the English industrial city 1840-1914, Manchester University Press, Manchester and New York.

Gunson, Niel 1978, Messengers of Grace: Evangelical Missionaries in the South Seas 1797-1860, Oxford University Press, Melbourne.

- 2002, 'Review article: Reality, history and hands-on ethnography: the journals of George Augustus Robinson at Port Phillip 1839-1852' Aboriginal History, Vol. 26.

Haebich, Anna 2000, Broken Circles:Fragmenting Indigenous Families 1800 2000, Fremantle Arts Centre Press, Fremantle, WA.

Haldane, Elizabeth S 1933, The Scotland of our Fathers: A Study of Scottish Life in the Nineteenth Century, Alexander Maclehose \& Co., London.

Hamilton, Paula 1994, 'The knife edge: debates about memory and history', in Kate Darian-Smith and Paula Hamilton (eds), Memory and History in Twentieth-Century Australia, Oxford University Press, Melbourne.

Harrison, Peter 1998, The Bible, Protestantism, and the Rise of Natural Science, Cambridge University Press, Cambridge and New York.

Healy, J J 1978, Literature and the Aborigine in Australia 1770 - 1975, University of Queensland Press, St Lucia, Queensland.

Hebb, Isaac 1970 [1888], The History of Colac and District, (first published in series in Colac Herald, 1888), The Hawthorn Press, Melbourne. 
Henderson, Alexander (ed.) 1936, Early Pioneer Families of Victoria and Riverina: A Genealogical and Biographical Record, McCarron, Bird \& Co., Melbourne.

Henderson, Alexander 1941, Henderson's Australian Families: A Genealogical and Biographical Record, A Henderson Publisher, Melbourne.

Henningham, Nikki 2001, “Hats off, gentlemen, to our Australian mothers!" Representations of white femininity in North Queensland in the early twentieth century', Australian Historical Studies, Vol. 32, No. 117.

Herman, Morton (ed.) 1965, Annabella Boswell's Journal: An Account of Early Port Macquarie, Angus \& Robertson, Sydney.

Hetherington, Penelope 2002, Settlers, Servants \& Slaves: Aboriginal and European Children in Nineteenth-century Western Australia, University of Western Australia Press, Nedlands, WA.

Hirsch, E D 1988, 'Faulty perspectives', in David Lodge (ed.), Modern Criticism and Theory: A Reader, Longman, London and New York.

Hobhouse, L T, G C Wheeler and M Ginsberg 1915, The Material Culture and Social Institutions of the Simpler Peoples: An Essay in Correlation, Chapman \& Hall, London.

Holland, Alison 2001, 'The campaign for women protectors: gender, race and frontier between the wars', Australian Feminist Studies, Vol. 16, No. 34.

Home, R W (ed.) 1988, Australian Science in the Making, Cambridge University Press in association with Australian Academy of Science, Cambridge and Melbourne.

Howard, Jonathan 1982, Darwin, Oxford University Press, Oxford.

Huggins, Jackie and Thom Blake 1992, 'Protection or persecution? Gender relations in the era of racial segregation', in Kay Saunders and Raymond Evans (eds), Gender Relations in Australia: Domination and Negotiation, Department of History, The University of Queensland, Harcourt Brace Jovanovich, Sydney.

Jebb, Mary Anne and Anna Haebich 1992, 'Across the Great Divide: gender relations on Australian frontiers', in Kay Saunders and Raymond Evans (eds), Gender Relations in Australia: Domination and Negotiation, Department of History, The University of Queensland, Harcourt Brace Jovanovich, Sydney.

Jeffrey, Julie Roy 1979, Frontier Women: The Trans-Mississippi West 1840-1880, American Century Series, Hill and Wang, New York. 
In the Eye of the Beholder

Jobson's Year Book: Public Companies of Australia and New Zealand, 1972, Jobson's Financial Services Pty Ltd, Sydney.

Johnston, Anna 2001, 'Antipodean heathens: the London Missionary Society in Polynesia and Australia, 1800-50', in Lynette Russell (ed.), Colonial Frontiers: Indigenous-European Encounters in Settler Societies, Manchester University Press, Manchester.

Jones, Dorothy 1961, Cardwell Shire Story, Cardwell Shire Council, Brisbane.

Kerr, Ruth S 1988, Confidence \& Tradition: A History of Esk Shire, Council of the Shire of Esk, Queensland.

Kiddle, Margaret 1983 [1961], Men of Yesterday: A Social History of the Western District of Victoria 1835-1890, Melbourne University Press, Melbourne.

Kidwell, Clara Sue 1992, 'Indian women as cultural mediators', Ethnohistory: The Official Journal of the American Society for Ethnohistory, Vol. 39, No. 2.

Labumore: Elsie Roughsey [Memmott, Paul and Horsman, Robyn (eds)] 1984, An Aboriginal Mother Tells of the Old and the New, McPhee Gribble/Penguin Books, Melbourne.

Lake, Marilyn 1993, 'Colonised and colonising: the white Australian feminist subject', Women's History Review, Vol. 2, No. 3.

- 1996, 'Feminist history as national history: writing the political history of women', Australian Historical Studies, No. 106.

Lake, Marilyn and Farley Kelly 1985, Double Time: Women in Victoria-150 Years, Penguin, Ringwood, Victoria.

Langmore, Diane 1989, Missionary Lives: Papua, 1874-1914, Pacific Islands Monograph Series, No. 6, University of Hawai'i Press, Honolulu.

Lark, P D and R A McKenzie 1988, History of the Australasian Pioneers' Club, Sydney, 1910-1988, Boolarong Publications for the Australasian Pioneers' Club, Sydney, Brisbane.

Lawson, Elizabeth 1989, Louisa Atkinson: The Distant Sound of Native Voices, Occasional Paper No. 15, English Department, University College, Australian Defence Force Academy, Canberra.

L'Estrange, Jan 1996, Belle of the Barcoo: Tambo: Genesis of Queensland's Central West, published by author, Tambo, Queensland.

Lilley, G W 1973, Story of Lansdowne: The History of a Western Queensland Sheep Station, The Landsdowne Pastoral Co. Ltd, Melbourne. 
— 1977, Lengthening Shadows: Memoirs of a Queensland Bushman and Queensland Historical Essays, Clark \& Mackay, Brisbane.

Loos, Noel 1982, Invasion and Resistance: Aboriginal-European Relations on the North Queensland Frontier 1861-1897, Australian National University Press, Canberra, and Miami, Florida.

Lynch, Sandra 2005, Philosophy and Friendship, Edinburgh University Press, Edinburgh.

McCorquodale, John 1987, Aborigines and the Law: A Digest, Aboriginal Studies Press, Canberra.

McGrath, Ann 1987, 'Born in the Cattle': Aborigines in Cattle Country, Allen \& Unwin, Sydney.

- 1989, 'Europeans and Aborigines', in Neville Meaney (ed.), Under New Heavens: Cultural Transmissions and the Making of Australia, Heinemann Educational Australia, Melbourne.

McGrath, Ann (ed.) 1995, Contested Ground: Australian Aborigines under the British Crown, Allen \& Unwin, St Leonards, NSW.

McGregor, Russell 1997, Imagined Destinies: Aboriginal Australians and the Doomed Race Theory, 1880-1939, Melbourne University Press, Carlton, Victoria.

McGuire, M E 1990, 'The legend of the Good Fella Missus', Aboriginal History, Vol. 14, Nos 1-2.

McKellar, Hazel (Tom Blake, ed.) 1984, Matya-Mundu: A History of the Aboriginal People of South West Queensland, Cunnamulla Australian Native Welfare Association, Cunnamulla, Queensland.

MacLeod, Roy and Philip F Rehbock (eds) 1994, Evolutionary Theory and Natural History in the Pacific: Darwin's Laboratory, University of Hawai'i Press, Honolulu.

Mahood, Marie 2002, Legends of the Outback, Central Queensland University Press, Rockhampton, Queesland.

— 2005, The Last Dry Creek, Central Queensland University Press, Rockhampton, Queensland.

Macquarie Dictionary, 1981. 
In the Eye of the Beholder

Marcus, Julie 1993, 'The Beauty, Simplicity and Honour of Truth: Olive Pink in the 1940s', in Julie Marcus (ed.), First in their Field: Women and Australian Anthropology, Melbourne University Press, Carlton, Victoria, and Portland, Oregon, USA.

Markus, Andrew 1974, From the Barrel of a Gun: The Oppression of the Aborigines 1860-1900, Victorian Historical Association, West Melbourne.

- 1994, Australian Race Relations 1788-1993, Allen \& Unwin, St Leonards, NSW.

Marty, Martin 1970, Righteous Empire: The Protestant Experience in America, The Dial Press, New York.

Massola, Aldo 1968, Aboriginal Place Names of South-east Australia and their Meanings, Lansdowne Press Pty Ltd, Melbourne.

Maxwell, Ian Douglas 2001, 'Civilization or Christianity? The Scottish debate on mission methods, 1750-1835', in Brian Stanley (ed.), Christian Missions and the Enlightenment, William B Eerdmans Publishing Company, Michigan, USA, Cambridge, UK.

Mennell, Philip 1892, The Dictionary of Australasian Biography, Comprising Notices of Eminent Colonists from the Inauguration of Responsible Government down to the present time, 1855-1892, Hutchinson \& Co., London.

Molesworth, B H 1917, 'Kanaka labour in Queensland [1863-1871]', Historical Society of Queensland Journal, Vol. 1, No. 3.

Moore, David R 1978, Islanders and Aborigines at Cape York: An Ethnographic Reconstruction Based on the 1848-1850 'Rattlesnake' Journals of O.W. Brierly and Information He Obtained from Barbara Thompson, Australian Institute of Aboriginal Studies, Canberra and Humanities Press Inc., New Jersey, USA.

Moretti, Franco 1983, Signs Taken For Wonders: Essays in the Sociology of Literary Forms, translated by Susan Fischer, David Forgacs and David Miller, Verso Editions, London.

Morphy, Howard and Frances Morphy 1984, 'The "myths" of Ngalakan history: ideology and images of the past in Northern Australia', Man: The Journal of the Royal Anthropological Society, London, Vol. 19, No. 3.

Morris, Barry 1989, Domesticating Resistance: The Dhan-Gadi Aborigines and the Australian State, St Martin's Press, Oxford, UK.

Moyal, Ann 1993, A Bright \& Savage Land, Penguin Books Australia Ltd, Ringwood, Victoria. 
Mulvaney, D J 1990, 'The Australian Aborigines 1606-1929: opinion and fieldwork', in Susan Janson and Stuart Macintyre (eds), Through White Eyes, Allen \& Unwin, Sydney.

Murphy, John 1986, 'The voice of memory: history, autobiography and oral memory', Historical Studies, Vol. 22, No. 87.

Murray, Francis 1969, 'Perilous passage', Holy Name Monthly: Official Organ of the Holy Name Society in Australia and New Zealand, Vol. XXXVIII, No. 9.

Naremburn Public School 1887-1987, 1987, Management Development Publishers Pty Ltd for The Centenary Committee of the Naremburn Parents and Citizens Association, Sydney.

Nelson, Elizabeth, Sandra Smith and Patricia Grimshaw (eds) 2002, Letters from Aboriginal Women of Victoria, 1867-1926, History Department, University of Melbourne, Melbourne.

Normanton Centenary 1868-1968, Normanton Centenary Committee, 1968.

Nunan, Jim 1971, Squatters \& Soldiers: Trawalla 1839 - 1971, The Back-ToTrawalla Committee for Trawalla School Centenary Celebrations, Trawalla, Victoria.

O'Brien, Patty 1998, ‘The Pacific Muse: Colonial Stereotypes of Indigenous Women in the Pacific', PhD Thesis, Department of History, Faculty of Arts, University of Sydney.

Paisley, Fiona 1997, 'No back streets in the bush: 1920s and 1930s pro-Aboriginal white women's activism and the Trans-Australia Railway', Australian Feminist Studies, Vol. 12, No. 25.

Palmer, Alison 2000, Colonial Genocide, Crawford House, Adelaide.

Pascoe, C F 1901, Two Hundred Years of the S.P.G.: An Historical Account of the Society for the Propagation of the Gospel in Foreign Parts 1701-1900, published at the Society's Office, London.

Pearn, John 1993, Steps Along the Path: Milestones in the history of the Royal Childrens's Hospital, Brisbane, Amphion Press, Brisbane.

Pettman, Jan 1992, Living in the Margins: Racism, Sexism and Feminism in Australia, Allen \& Unwin, North Sydney.

Poignant, Roslyn 2004, Professional Savages: Captive Lives and Western Spectacle, Yale University Press, New Haven and London. 
In the Eye of the Beholder

Pratt, Mary Louise 1977, Towards a Speech Act Theory of Literary Discourse, Indiana University Press, Bloomington and London.

- 1992, Imperial Eyes: Travel Writing and Transculturation, Routledge, London.

Preston, Diana and Michael Preston 2004, A Pirate of Exquisite Mind, Explorer, Naturalist, and Buccaneer: The Life of William Dampier, Walker \& Company, New York.

Price, A Grenfell 1972 [1950], White Settlers and Native Peoples: An Historical Study of Racial Contacts between English-speaking Whites and Aboriginal Peoples in the United States, Canada, Australia and New Zealand, Greenwood Press, Westport, Connecticut (originally published by Georgian House, Melbourne).

Rae-Ellis, Vivienne 1979, Louisa Anne Meredith: A Tigress in Exile, Blubber Head Press, Sandy Bay, Tasmania.

Rayment, B J c. 1971, My Towri, Tabra Press, Jundah, Queensland.

Reader, W J 1974, Victorian England, B T Batsford Ltd, London, and G P Putman's Sons, New York.

Reece, R H W 1974, Aborigines and Colonists: Aborigines and Colonial Society in New South Wales in the 1830s and 1840s, University of Sydney Press, Sydney,

Reeves, Margaret 1985, A Strange Bird on the Lagoon, Boolarong Publications, Brisbane.

Reynolds, Henry 1990, The Other Side of the Frontier: Aboriginal Resistance to the European Invasion of Australia, Penguin Books, Ringwood, Victoria.

Reynolds, Henry (ed.) 1993, Race Relations in North Queensland, James Cook University, Townsville, Queensland.

Reynolds, Henry 1996 [1987], Frontier: Aborigines, Settlers and Land, Allen \& Unwin, St Leonards, NSW.

— 1996, 'Frontier History After Mabo', Journal of Australian Studies, Australian Frontiers, No. 49.

Richards, I A 1925, Principles of Literary Criticism, Kegan Paul, Trench, Trubner \& Co. Ltd, London, and Harcourt, Brace \& Co. Inc., New York. 
Richards, Jonathan 1999, 'Moreton Telegraph Station: 1902 the Native Police on Cape York Peninsula', Paper presented at the History of Crime, Policing and Punishment Conference, convened by the Australian Institute of Criminology in conjunction with Charles Sturt University, Canberra, 9-10 December 1999: E-journal.

— 2008, The Secret War: A True History of Queensland's Native Police, University of Queensland Press, St Lucia, Queensland.

Riddett, Lyn 1993, "Watch the white women fade": Aboriginal and white women in the Northern Territory 1870-1940', Hecate, Vol. 19. No. 1.

Riley, Glenda 1984, Women and Indians on the Frontier 1825-1915, University of New Mexico Press, Albuquerque, USA.

- 1988, The Female Frontier: A Comparative View of Women on the Prairie and the Plains, University Press of Kansas, Lawrence, USA.

Ritvo, Harriet 1997, The Platypus and the Mermaid and Other Figments of the Classifying Imagination, Harvard University Press, Cambridge, Massachusetts and London, England.

Roberts, D 1979, Paternalism in Early Victorian England, Rutgers University Press, New Jersey.

Roberts, Stephen 1964, The Squatting Age in Australia, 1835-1847, Melbourne University Press in association with Oxford University Press, Melbourne.

Roberts, Tony 2005, Frontier Justice: A History of the Gulf Country to 1900, University of Queensland Press, Queensland.

Robinson, Fergus and Barry York 1977, The Black Resistance: An Introduction to the History of the Aborigines' Struggle against British Colonialism, Widescope International Publishers Pty Ltd, Camberwell, Victoria.

Rose, Deborah Bird 1991, Hidden Histories: Black Stories from Victoria River Downs, Humbert River and Wave Hill Stations, Aboriginal Studies Press, Canberra.

Rowley, C D 1971, 'Aborigines and the land', in Identity, The Aboriginal Publications Foundation Inc., Sydney, Vol. 1, No. 1.

Rowse, Tim 1986, 'Aborigines As historical actors: evidence and inference', Historical Studies, Vol. 22, No. 87. 
In the Eye of the Beholder

— 1987, “Were you ever savages?" Aboriginal insiders and pastoralists' patronage', in L R Hiatt and Francesca Merlan (eds), Oceania, University of Sydney, Vol. 58, No. 1.

— 1988, 'Paternalism's changing reputation', Mankind, Vol. 18, No. 2.

- 1998, White Flour, White Power: From Rations to Citizenship in Central Australia, Cambridge University Press, Cambridge, Melbourne.

Rusden, G W, History of Australia 1883, Volumes I-III, Chapman and Hall Ltd, London, George Robertson, Melbourne and Sydney.

Russell, Lynette (ed.) 2001, Colonial Frontiers: Indigenous-European Encounters in Settler Societies, Manchester University Press, Manchester.

Russell, Penny 1994, 'A Wish of Distinction': Colonial Gentility and Femininity, Melbourne University Press, Carlton, Victoria.

- 2010, Savage or Civilised: Manners in Colonial Australia, UNSW Press, Sydney.

Ryan, Lyndall 1986, 'Aboriginal women and agency in the process of conquest: a review of some recent work', Australian Feminist Studies, No. 2.

— 1996, The Aboriginal Tasmanians, Allen \& Unwin, St Leonards, NSW.

Ryan, Simon 1996, The Cartographic Eye: How Explorers Saw Australia, Cambridge University Press, Cambridge, Melbourne.

Sabbioni, Jennifer, Kay Schaffer and Sidonie Smith (eds) 1998, Indigenous Australian Voices: A Reader, Rutgers University Press, New Brunswick, New Jersey and London.

Sangster, Paul 1963, Pity My Simplicity: The Evangelical Revival and the Religious Education of Children 1738-1800, The Epworth Press, London.

Saunders, Kay 1991, 'All the women were white? Some thoughts on analysing race, class and gender in Australian history', in Carole Ferrier (ed.), Women/ Australia/Theory: Special Issue of Hecate, Hecate Press in association with the Unit for Women, Ideology and Culture Research (WICR), St Lucia, Queensland, Vol. 17, No. 1.

Schaffer, Kay 1989, Australian mythologies: the Eliza Fraser story and constructions of the feminine in Patrick White's novel A Fringe of Leaves and Sidney Nolan's "Eliza Fraser" paintings', Kunapipi, Vol. 11, No. 2, Dangaroo Press, Aarhus, Denmark. 
— 1991, 'Eliza Fraser's trial by media', Antipodes; A North American Journal of Australian Literature, Vol. 5, No. 2.

— 1993, 'Captivity narratives and the idea of "nation"”, in Kate Darian-Smith, Roslyn Poignant and Kay Schaffer (eds), Captured Lives: Australian Captivity Narratives, Working Paper in Australian Studies No. 85, Sir Robert Menzies Centre for Australian Studies, Institute of Commonwealth Studies, University of London.

- 1994, 'Colonizing gender in colonial Australia: the Eliza Fraser story', in Gillian Rose and Alison Blunt (eds), Writing, Women and Space: Colonial and Postcolonial Geographies, Guilford Press, New York.

- 1995, In the Wake of First Contact: The Eliza Fraser Stories, Cambridge University Press, Cambridge, New York.

— 1998, "We are like Eliza": twentieth-century Australian responses to the Eliza Fraser saga', in Ian J McNiven, Lynette Russell and Kay Schaffer (eds), Constructions of Colonialism: Perspectives on Eliza Fraser's Shipwreck, Leicester University Press, London and New York.

Schindler, C 1916, 'Non-British [German] settlement in Queensland', Historical Society of Queensland Journal, Vol. 1, No. 2.

Schneewind, J B 1970, Backgrounds of English Victorian Literature, Random House, New York.

Seagrave, Gordon S 1946, Burma Surgeon Returns, Besley \& Pike Ltd, Brisbane.

Shaw, A G L 1996, A History of The Port Phillip District: Victoria Before Separation, Melbourne University Press, Carlton, Victoria.

Sheridan, Susan 1995, Along the Faultlines: Sex, Race and Nation in Australian Women's Writing 1880s - 1930s, Allen \& Unwin, St Leonards, NSW.

Siemon, Rosamond 2003, The Mayne Inheritance: A Gothic Tale of Murder, Madness and Scandal across the Generations, University of Queensland Press, St Lucia, Queensland.

Sinclair, John 1990, Fraser Island and Cooloola, Weldon Publishing, Willoughby, NSW.

Slotkin, Richard 1973, Regeneration Through Violence: The Mythology of the American Frontier, 1600-1860, Wesleyan University Press, Middletown, Connecticut. 
In the Eye of the Beholder

Smith, Bernard 1985, European Vision and the South Pacific, Harper \& Rowe, Sydney.

Spender, Dale 1988, Writing a New World: Two Centuries of Australian Women Writers, Pandora, London and New York.

Spender, Lynne (ed.) 1988, Her Selection: Writings by Nineteenth-Century Australian Women, Penguin Books, Ringwood, Victoria.

Spreadborough, Robert and Hugh Anderson 1983, Victorian Squatters, Red Rooster Press, Ascot Vale, Victoria.

St Clair, William 1977, Trelawny: The Incurable Romancer, John Murray, London.

Steele, J G 1975, Brisbane Town in Convict Days 1824-1842, University of Queensland Press, St Lucia, Queensland.

Stephenson, A W 1940, Pioneering For Christian Unity in Australia and New Zealand: Being an Outline of the History of Churches of Christ in Australia and New Zealand and a Brief Study of their Teachings and Ideals, The Austral Printing and Publishing Co. Ltd, Melbourne.

Stephenson, A W (ed.) 1946, One Hundred Years: A Statement of the Development and Accomplishments of Churches of Christ in Australia, The Austral Printing and Publishing Co. Ltd, Melbourne.

Strehlow, T G H 1956, The Sustaining Ideals of Australian Aboriginal Societies, The Hawthorn Press, Melbourne.

Stringer, Jenny (ed.) 1996, The Oxford Companion to Twentieth-Century Literature in English, Oxford University Press, Oxford, New York.

Sullivan, Marjorie 1996, 'Northern Australian landscapes', in Peter Veth and Peter Hiscock (eds), Archaeology of Northern Australia: Regional Perspectives, Tempus, Vol. 4, Anthropology Museum, University of Queensland.

Swann, Margaret 1929, 'Mrs Meredith and Miss Atkinson, writers and naturalists', Royal Australian Historical Society Journal and Proceedings, Vol. $\mathrm{XV}$, Part 1 .

Taylor, H R n.d., The History of Churches of Christ in South Australia 1846-1959, The Churches of Christ Evangelistic Union Incorporated, South Australia, Adelaide.

- 1946, The Story of a Century: A Record of the Churches of Christ Religious Movement in South Australia 1846-1946, The Austral Printing and Publishing Co Ltd, Melbourne. 
Thomson, Helen 1993, 'Gardening in the Never-Never: women writers and the bush', in Ferres, Kay (ed.), The Time to Write: Australian Women Writers 1890-1930, Penguin Books, Ringwood, Victoria.

Tindale, Norman B 1974, Aboriginal Tribes of Australia: Their Terrain, Environmental Controls, Distribution, Limits, and Proper Names, Australian National University Press, Canberra.

Tonkinson, Myrna 1988, 'Sisterhood or Aboriginal servitude? Black women and white women on the Australian frontier', Aboriginal History, Vol. 12, Nos 1-2.

Trumpener, Katie 1997, Bardic Nationaliam: The Romantic Novel and the British Empire, Princeton University Press, USA.

Tyrrell, Alex 1993, A Sphere of Benevolence: The Life of Joseph Orton, Wesleyan Methodist Missionary (1795-1842), State Library of Victoria, Melbourne.

Vance, Norman 1985, The Sinews of the Spirit: The Ideal of Christian Manliness in Victorian Literature and Religious Thought, Cambridge University Press, Cambridge, New York.

Van Toorn, Penny 1995, Rudy Wiebe and the Historicity of the Word, University of Alberta Press, Edmonton, Canada.

- 2006, Writing Never Arrives Naked: Early Aboriginal Cultures of Writing in Australia, Aboriginal Studies Press, Canberra.

Van Toorn, Penny and David English (eds) 1995, Speaking Positions: Aboriginality, Gender and Ethnicity in Australian Cultural Studies, Department of Humanities, Victoria University of Technology, Melbourne.

Walsh, Kay and Joy Hooton 1993, Australian Autobiographical Narratives: An Annotated Bibliography, Volume 1: To 1850, Australian Scholarly Editions Centre, University College, Australian Defence Force Academy, Canberra.

- 1998, Australian Autobiographical Narratives: An Annotated Bibliography, Volume 2, 1850-1900, Australian Scholarly Editions Centre, University College, Australian Defence Force Academy, Canberra.

Walvin, James 1973, Black and White: The Negro and English Society 1555-1945, Allen Lane, The Penguin Press, London.

Ward, Barbara 1994, A Lady in a Thousand: Eliza Davies, A Biography, Wild \& Woolley Pty Ltd, Glebe, NSW. 
In the Eye of the Beholder

Watson, Donald and Judith McKay 1994, Queensland Architects of the 19th Century: A Biographical Dictionary, Queensland Museum, Brisbane.

Watt, Ian 1963, The Rise of the Novel: Studies in Defoe, Richardson, and Fielding, Penguin Books in association with Chatto \& Windus, Mitcham, Victoria.

Wildman, Owen c. 1920, Queenslanders Who Fought in the Great War, Besley \& Pike Ltd, Brisbane.

Williams, Raymond, The Long Revolution, Chatto \& Windus, London, 1961.

Wright, Judith 1991, Born of the Conquerors: Selected Essays, Aboriginal Studies Press, Canberra.

- 2004, The Cry for the Dead, API Network, Australian Research Institute, Perth.

Yarwood, A T and M J Knowling 1982, Race Relations in Australia: A History, Methuen Australia, North Ryde, NSW.

Young, G M 1953, Victorian England: Portrait of an Age, Oxford University Press, London, New York.

Young, Linda 2003, Middle-Class Culture in the Nineteenth Century: America, Australia and Britain, Palgrave Macmillan, Hampshire, UK.

\section{Websites}

Bruce Pascoe, Wathaurong Co-operative, 'History', Barwon Bluff Marine Sanctuary, http://www.barwonbluff.com.au/archive/koorie/History.htm.

'Cincinnati', Wikipedia, wikipedia.org/wiki/Cincinnati.

Daryl Lundy (compiler), The Peerage: a genealogical survey of the peerage of Britain as well as the royal families of Europe, Wellington, New Zealand, http://www.thePeerage.com, Person Page 13589, No. 135884 and No. 27474; http://www.thePeerage.com, Nos 135882, 37368, 135885.

Parliament of Victoria, www.parliament.vic.gov.au.

Rainbow Spirit Warriors, 'Ka'bi Aboriginal Cultural Histories of S. E. Queensland', Australia, www.warriors.egympie.com.au/. 


\section{Index}

A Mother's Offering to her Children (1841) 25,163

Aboriginal people

Christianising xviii, xxiv, 7, 100, 107, 108-11, 113, 115-20

'civilised', 'station' Aborigines xvii, xviii, 78, 94, 95, 97, 110, 112, 114, $115-20,128,138,142-46$

corroboree 42-44, 79-80, 136

groups and individuals

Arabanoo 6

Balardung 63

Batjali (Butchala) 17

Bennelong 110

Bindal 55

Coorooboolka (Coorabulka): ('Minnie', 'Tommy', 'Dick') 143,149

Dallambara 120

Darug 6

Dungibara ('Clara', 'King Billy', 'Kitty', 'Long Kitty', 'Piggie Nerang', 'Polly', 'Topsy') xxiv, xxv, 101, 106, 115-20, 123, 152

Durundur, Alpin Edward 108-11, 115

'George' (possibly Pte George Robert Aitken) 139-40

Gundungorra 83

Jarildekald (Jeraldkeld) 40

Jurn 55

Ka'bi xxiii, 12, 15-25

Kamilaroi and Kurnai 2, 148

Karuwali 148

Kaurareg 55-56

Kuku-Yalanji 56

Kurtjar xxiv, 52, 61-64, 67-70, 151

Makadamas (Lama Lama) 55

Marrula 148

Meru xxiv, 32, 37-38, 40, 151

'Minnie' xxi, 142-49

Mitaka 148
Moner balug xxiv, 74, 83-88, 92, 94-96, 97, 152

Ngaiawang 40

Nganguruku 40

Ngaralta 40

Ngarrindjeri xxiv, 32, 37-38, 40$41,47,151$

Noongahburrah 147, 148

Pitta Pitta 143, 145

Porta'ulun 40

Raminyeri (Ra:Mindjeri) 40

Turrbal (Yugarabul language group) 104-105

Wadjalang ('Dinah', 'Harry') 127, $128,136-38$

Waka Waka 101, 111

Warki 40

Wathaurong (Watha wurrung,

Wada warrung) xxiv, 74, 75, 78$80,84,91-92,98,152$

Wiilman 148

Yadhaigana 56, 59

Yuwaalaraay (Yuwalaraay, Euahlayi) $\mathrm{xx}, 148$

'outsiders', 'wild' xvii, xviii, 2, 7, 16,

$26,31,41,43,50,59,68,78,79$,

$90,91,94,97,112,139$

Adelaide, Debra xix

Allingham, Anne xix

Angas, George Fife 37

anthropologists 2

Attwood, Bain xvii, xviii

Australian Agricultural Co. 101, 129, 130

Banks, Joseph 4-5, 32, 44, 56

Banks, Mary Macleod (born McConnel)

$111,118-19,122$

Barnum, Phineas Taylor 33-34, 44, 108

Barwick, Diane xviii, 119

Bates, Daisy 149

Baxter, John 13, 14, 24, 27

Bentham, Jeremy 4, 100-101

Berndt, Catherine 18, 79-80

Berndt, Ronald 18, 79

Blake, Thom xx

Boldrewood, Rolf (Thomas Browne) 65, 92 
Bowden Public School (Hindmarsh, South Australia) 37

Brewster, Anne 117

Bride, Thomas Francis 77, 86, 92

Brisbane's Hospital for Sick Children

(Royal Children's Hospital) 121

Broome, Richard xviii

Brown, Charles 13, 14, 22-24

Brown, Elaine 23

Bryan, Henry Guy 38-39, 45, 48, 49

Bulimba 100, 103-106, 114, 115

Bundock, Mary xx

Butcher, Barry 1

Bynoe, Charles 68

Campbell, Rev'd Alexander 35-36

cannibalism 22-23, 27, 33, 38, 45, 46, 49

Chambers, Robert 74, 96

Channel Country xxv, 83, 132-134, 135, 138,152

Child Villiers, Margaret (Dowager Countess of Jersey) 43

Christian evangelicalism xxii, 2, 7, 26, 27, 35-37, 106-107, 108, 114-15, 121, 123,151

Christie, Michael xviii

Christison, Robert 153

Cincinnati, USA 35, 37

Clarke, Patricia xix

Clendinnen, Inga xxi

Clermont flood 140

Cole, Anna xx

Collie, Alexander 107

Cook, James 3, 4

Cooper, James Fenimore 26, 44, 45

Cowen, (Annie) Rose Scott (born Hamilton) xviii, xxi, xxii, xxv, 98, 125-49, 152

Cowen, William 132, 144, 146

Cowl, Emily xviii, xix, xxii, xxiv, 51-70, $74,100,124,151-52$

Cowl, Thomas Holder 51, 53, 54, 57, 58, $62,64,67$

Cressbrook (near Esk, Queensland) xxiv, 100-103, 106, 108, 111-122, 152

Curr, Edward 153
Curthoys, Ann xx, xxi

Curtis, John 27-28, 46, 49

Daly, Harriet (Mrs Dominic) 43

Dampier, William 3-4, 5, 55

Darge, Robert 23, 27

Darling Downs (Queensland) 43, 101, $103,111,132,134,135$

Darwin, Charles 1-2, 6, 31-32, 44, 147

Davies, Eliza xix, xxii, xxiii-xxiv, 29-50, $51,52,55,68-69,74,151,152$

Davies, William 35, 36

Dixon, Robert 65

Duncan-Kemp, Alice 83, 148

education (female) xvii, 2-7, 30, 78, 102

Enlightenment xxii, 4, 103

evangelicalism, see Christian evangelicalism

Evans, Julie $\mathrm{xx}$

Evans, Raymond xviii, $\mathrm{xx}, 59$

evolutionary theory, 2, 32, 96, 149

Farquhar, Sir Walter, 1st Baronet 128-29

Fels, Marie xviii

feminism 128, 146

Fisher, Charlotte 78, 94

Fisher David (manager of Derwent Company) 76, 78

Flanagan, Roderick 33

Foster, Robert xvii, xxi, 115

Foster, Stephen 112-13, 148

Francis, Mark 2

Fraser, Eliza xv, xvi, xxi-xxiii, 11-28, 44, $46,49,52,55,60,69,90,151,152$

Fraser, James 13, 14, 22-24

friendship (cross-cultural female) xviii, xix, xx, xxi, xxii, 8, 69, 85-89, 97, $98,113,142-45,147-49,152-53$

Frost, Lucy xix

Fyans, Foster xxiii, 90

Gawler, George xxiii, 30-31, 38-41, 44, 48

Gawler, Julia 31, 39, 40-41, 44, 45, 47

Geelong (Victoria) xviii, 76, 77, 78, 85, $89,90,91,94,97$

Gilbert, Rolly 68 
Giles, Fiona xix

Gliddon, George 31, 32, 33

Gould, John 49

Graham, John 19, 23, 24

Green, Neville xviii

Greene, Alexander John 25

Grenville, Kate xxi

Griffiths, Tom xxi, 94, 98

Grimshaw, Patricia xix, xx, 59

Gunn, Jeannie 147

Gunson, Niel xxi, 35, 106, 107

Haebich, Anna xx, 108

Haggard, H Rider 64-66

Hamilton, Alice (born Scott) 127, 128, 130

Hamilton, Venerable Anthony 129

Hamilton, Edward William Terrick 129, 130,131

Hamilton, James 76, 86, 93, 94, 96

Hamilton, Paula xxi

Hamilton, Robert 75, 76, 83, 91, 93

Hamilton, Terrick Alfred 127, 128-29, 130-31, 137

Hamilton, Walter Kerr 129

Haskins, Victoria $\mathrm{xx}$

Hassell, Ethel 147-48

history and fiction xxi, xxiii, 39, 45, 50, $67,77-78$

Hosking, Rick xxi

Huggins, Jackie $\mathrm{xx}$

Hume, David 1, 6

Jebb, Mary Anne xx

Jundah (Queensland) xiv, 132, 141, 142, 146

Kanakas 120-21

Kangaroo Point Military Hospital, Brisbane 147

Kelly, Farley xix

Kiama, NSW 36

Kilcoy station 60, 120

Kirkland, Katherine xviii, xxii, xxiv, 7398, 100, 113, 152

Kirkland, Kenneth (senior) 76, 96,

Lake, Marilyn xix, 59, 146-47 landscape xxi-xxii, 26, 47, 49, 50, 55, 56$58,59,66,68,77-78,86,113$, $132,133-34$

Lang G S 59

Lang, Rev'd Dr John Dunmore 102, 103, 117

Lawson, Elizabeth xix, 83

legislation

Aboriginal Fire Arms Regulation Act 1840 (NSW) 114

Aboriginals Protection and Restriction of the Sale of Opium Act 1897 (Qld) 59

Licensed Publicans Act 1838 (NSW) 114

Master-Servant Act of 1823 (England) 18

Masters and Servants Act 1857 (NSW) 113

Police Act, 1863 (Qld) 63; Public

Schools Act, 1866 (NSW) 37

Queensland Election Acts of 1872 and 1874114

Lexington, USA 31

literary analysis xviii, xix, xxi, 26, 44, $50,61,66-67,117,151$

literary styles xxii, xxiii, xxiv, 8, 12-13, $22,26-27,34-35,38,40,41,44,45-$ $48,50,52,54,55,61,64-67,69,78$, $96,124,151$

London Missionary Society 27, 107

Long, Edward 33

Longford (Channel Country) 138-40, 14247,149

Loos, Noel xviii

Lumholtz, Karl 136

Lynch, Sandra xxi

Macarthur, John 129

McConnel, A J 111

McConnel, David Cannon xxiv, 101-106, 109-11, 113-15, 119-22

McConnel, Frederic 111

McConnel, J H (Harry) 100, 105, 122

McConnel, John 111, 112

McConnel, Mary (born Macleod) xviii, 
xxii, xxiv, 98-124, 146, 152

McGrath, Ann xviii, xix, xxi, 59, 107, $117,119,144$

McGuire, M E 123

McKenna, Mark xxi

Macpherson, Emma (Mrs Allan) 112-13, 117,148

Magarey, Thomas 36, 37

Mahood, Marie 126

Markus, Andrew xviii, 149

Mathew, John 20, 21, 23

memory, role of $\mathrm{xvii}, \mathrm{xxi}, 98$

Miller, Alex xxi

Mitchell, David Scott 128

Mitchell, Sir Thomas 43

Montagu, George Victor Drogo, Viscount Mandeville, 8th Duke of Manchester 129

Morehead, Boyd Dunlop 129

Morris, Barry 117

Mort, Henry 102, 111

Morton, Samuel George 32

Mulvaney, John xviii

Murphy, Sir Francis 129

Murray River xxiii, 30, 39, 43, 47

Nettelbeck, Amanda xxi

Normanton (Queensland) xxiv, 51-54, 56$60,61,63,68,69-70$

Nott, Josiah 31, 32, 33

Otter, Lieutenant 23

Paisley, Fiona xx, 146

Palm Island Aboriginal Settlement 145

Parker, Katie Langloh (Catherine Stow) $\mathrm{xx}, 147-48$

paternalism 101, 103, 113, 115, 116, 12021,123

Petrie, Andrew 103

phrenology 33, 41

Pink, Olive 147

Pioneers Clubs xxiv, 51, 60-61

Port Phillip Aboriginal Protectorate 90

Praed, Rosa Campbell xx

publishers, role of 4, 8, 13, 47, 69, 92-93, 151
Quartly, Marian 59

Queen Victoria 132

racism xxiii, $1-3,5,7,8,18,33,47,48-$ $49,114,139-40,144,151-53$

Rayment B J 141

Reece, R H W (Bob) xviii

religions, see also Christian evangelicalism Baptist 35

Calvinism 106

Church(es) of Christ 35-37

Church of England 58, 63, 114, 129

Church of England Diocesan

Committee of the Societies for the Propagation of the Gospel in Foreign Parts 107

Dissenter 35

Methodist 114

missions 106-107, 114, 116, 119, 121

Presbyterian 13, 58, 97, 104, 105, $106,114-15,121$

Wesleyan 114

respectability, middle-class $\mathrm{xxiii,} \mathrm{xxv}, 2$, $7-8,16,19,53,57,58-59,63,75,80-$ $81,85,95,96,97,101,116-17,130$, $131,135,147$

Reynolds, Henry xviii, 95

Riddett, Lyn xix

Robinson Crusoe (Defoe, Daniel) 3, 22, 34, 55,78

Robinson, Fergus 92

Robinson, George Augustus 92

Rowse, Tim xvii, 115, 119,

Rusden, Rev'd George Keylock 129

Russell, George (founder of Clyde

Company) 76, 79, 80, 91

Russell, Penny 8, 80

Ryan, Lyndall xviii, xix

Saunders, Kay xix, xx, xxi

Schaffer, Kay 26

Scott, Helenus 129

Scott, Robert 128, 129

Scott, Rose 128, 146

Scott, Sarah (born Rusden) 128

Scott, Sir Walter xxiv, 34, 50, 65 
shearers' strike (1891) 131

shipwreck xxiii, 12-14, 54-55

silences xviii, xxi, xxii, xxiv, 52, 73, 75 , $86,89,92,93,94,97-98,112,151,152$

Smith, Christina (Mrs James) 111

Smith, Sir Donald (Lord Strathcona) 132

Spender, Dale xix

Spender, Lynne xix

Standish, Anne xx

Stevenson, John 129

Strehlow T G H 79

Sturt, Charles xxiii, 30-31, 38, 40, 41, 44

Sturt, Charlotte 31, 35, 39

Sydney Gazette 22, 24, 26

Tambo (Queensland) xxv, 127, 129, 130-

31, 134-138

Tench, Watkin 5-6

Thomson, Dr Alexander 76

Thomson, Sir Edward Deas 129

Thomson, Helen xix

Tonkinson, Myrna xx, 148

Toogoolawah, Queensland 100, 102, 103, 122

Trawalla, Western District, Victoria 74 ,

$76,77,82,83-87,90,91,92-93,94,97$

Uhr, Edmund 112

utilitarianism xxii, 4, 63, 100-101, 151

violence (frontier) xvii, xviii, 41, 59-60,

$63,67,68,69,70,89-94,95-96,97$,

98, 111-12, 120, 136-38, 139, 144, 145

massacres

Cullinlaringo 137

Hornet Bank 137

Myall Creek 37-38

Wamakee 68

Native Police 52, 62-63, 67, 68, 111, 137

Wallace, Alfred Russel 2

Warrah station (near Quirindi, NSW)

130, 137

Wickham, Captain John 102, 103

Willoughby Public School 36
York, Barry 92

Young, Linda 8

Yuille, George, William and Ardey 78, 80, 90,91 
